$$
\text { th. } 2025
$$

ORNL-5408

\title{
MASTER
}

\section{Safety Analysis Report for Packaging (SARP) of the Oak Ridge National Laboratory Garden Carrier No. 2}

\author{
B. B. Klima \\ L. B. Shappert \\ R. D. Seagren \\ W. D. Box
}

NOTICE

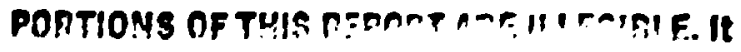

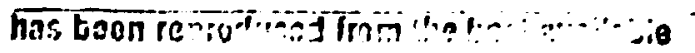
cony to permit the broadest possisile avait ability. 
Contract No. W-7405-eng-26

\title{
CHEMICAL TECHNOLOGY DIVISION \\ Pilot Plant Section
}

SAFETY ANALYSIS REPORT FOR PACKAGING (SARP) OF THE

OAK RIDGE NATIONAL LABORATORY GARDEN CARRIER NO. 2

\author{
B. B. Klima* \\ L. B. Strappert \\ R. D. Seagren \\ W. D. Box
}

-Retired. Present address: Roane State Community Collage, Harriman. Tennessee.

\section{OAK RIDGE NATIONAL LABORATORY \\ Oak Ridge, Tennessee 37830 operated by \\ UNION CARBIDE CORPORATION for the \\ DEPARTMENT OF ENERGY}


TABLE OF CONTENTS

ABSTRACT

1. INTRODUCTION

1.1 Description of the Pactage.

1.2 Contents of the Package ...................................... 5

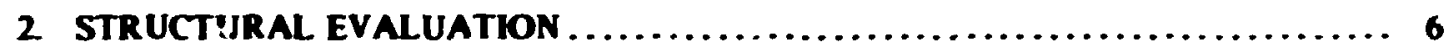

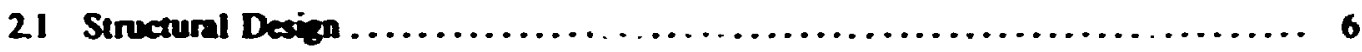

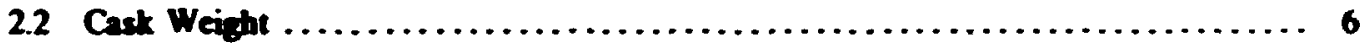

23 Mechanical Properties of Materials............................... 6

3. GENERAL StandardS for ALL PACKAGES $\ldots \ldots \ldots \ldots \ldots \ldots \ldots \ldots \ldots \ldots$

3.1 Chemical and Galvanic Reactions ............................. 10

3.2 Package Closure ......................................... 10

3.3 Package Lifting Devices .................................. 10

3.3.1 Garden Carrier No. 2 lifting trunnions..................... II

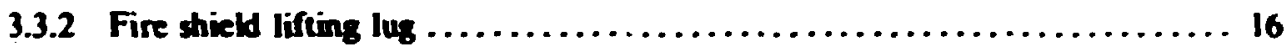

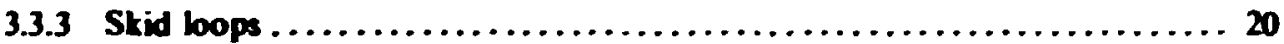

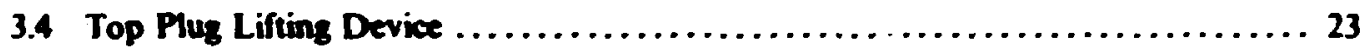

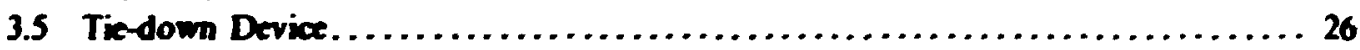

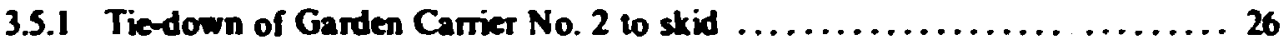

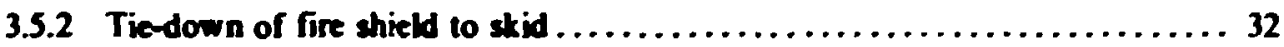

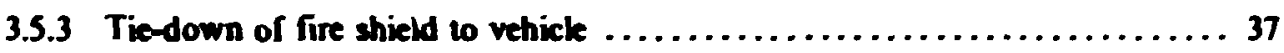

4. STANDARDS FOR TYPE B AND LARGE QUANTITY PACKAGING........ 45

4.1 Lond Resistarax . .............................................. 45

4.I.I Load resistance of Garden Carrier No. 2 ....................... 46

4.1 .2 Load resistance of the fire shield $\ldots \ldots \ldots \ldots \ldots \ldots \ldots \ldots \ldots \ldots . \ldots . \ldots$

4.2 External Prescure .......................................... 49

5. COMPLIANCE WITH STANDARDS FOR NORMAL CONDITIONS

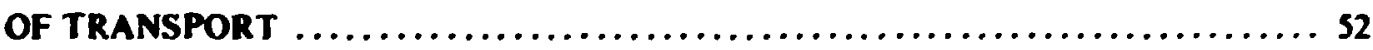

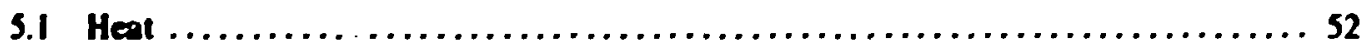

5.1.1 Thermal properties of materials.......................... 52

5.1.2 Thermal model for transport of solids $\ldots \ldots \ldots \ldots \ldots \ldots \ldots \ldots \ldots \ldots, 52$

5.1.3 Maximum temperatures ............................... 56

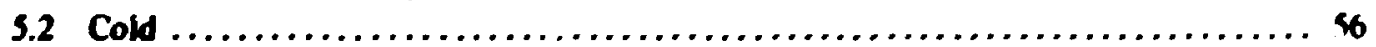

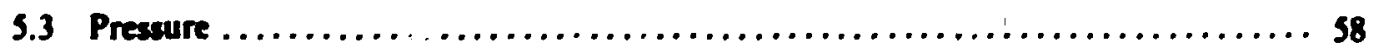

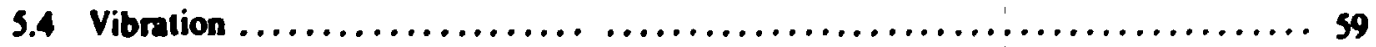

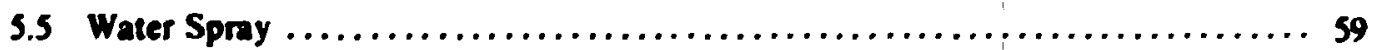




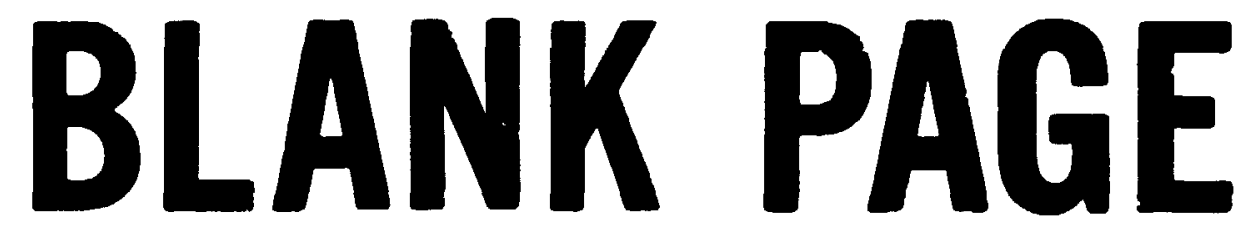


Page

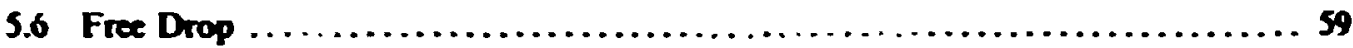

5.7 Denetration .. . ............................................ sq

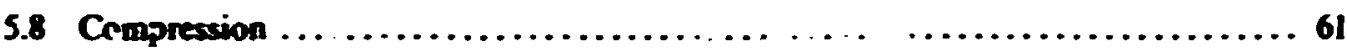

6. COMPLIANCE W.'ITH: STANDARDS FOR H IPOTHË TICAL

ACCIDENT CONDIR IONS .................................... 61

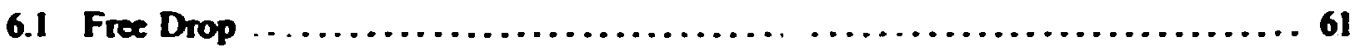

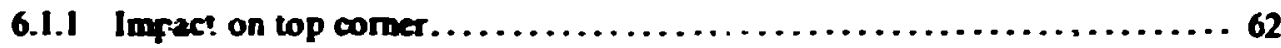

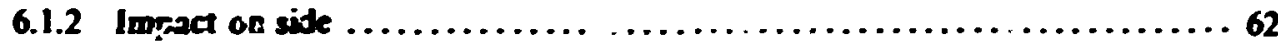

6.1.3 Bolts halding drawers ................................62

6.1.4 Bolts holding top plug .................................. 67

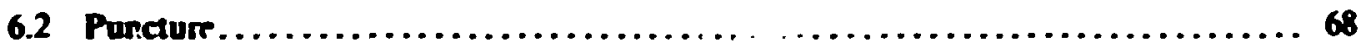

6.3 Thermal Evaluation ...................................... 68

63.1 Hypothetion thermal accident co:ditisf Jiscussion.................68 68

6.3.2 Thermal properties of materials..... .......................69 69

6.3.3 Thermal accident andysis .............................69

6.3.4 Temperatures as a result of the thermai aecident analysis.............69 69

6.3.5 Maximum intermal pressures ...... $\ldots \ldots \ldots \ldots \ldots \ldots \ldots \ldots \ldots \ldots$

6.4 Water Immetrion ............................................... 70

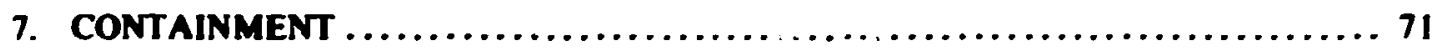

7.1 Containment Requirements for Normal C.jrditions of Transport ............ 76

7.2 Containment Requirements During the Hy:othetical Accident ............. 75

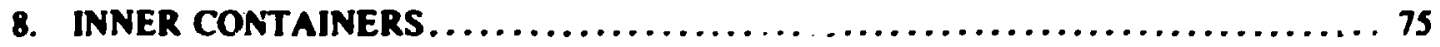

8.1 Screw-Top Inner Container .................................. 75

8.1.1 Inner container wall thickne' $;$................................ 77

8.1.2 Inner container bottom flathead thickness $\ldots \ldots \ldots \ldots \ldots \ldots \ldots \ldots \ldots 77$

8.1.3 inner container top head thickness ........................... 78

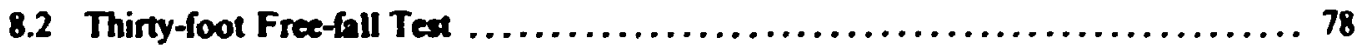

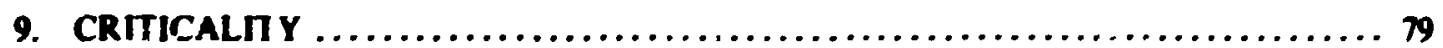

9.1 Evaluation of a Single Packaze .............................. 79

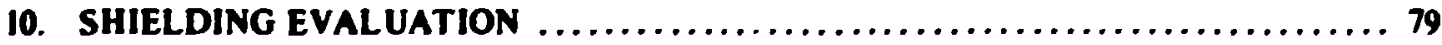

10.1 Discussion and Results ...................................... 79

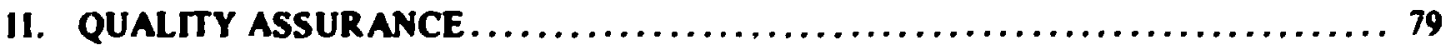

11.I Fabrication, Inspection and Acceptarre Teats ....................... 79

11.2 Operating Procedures and Routine Inspections $\ldots \ldots \ldots \ldots \ldots \ldots \ldots \ldots \ldots$

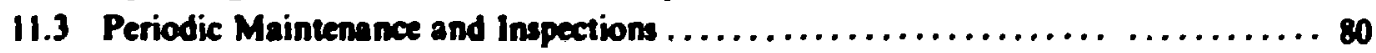


Page

12. APPERij1XES $\ldots \ldots \ldots \ldots \ldots \ldots \ldots \ldots \ldots \ldots \ldots \ldots \ldots \ldots \ldots \ldots \ldots$

12.1 Append: A - Drawings............................... 82

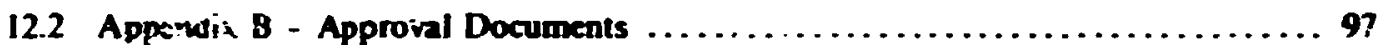

12.3 Apperdix C: Computer Program to Catculate :omer Drop

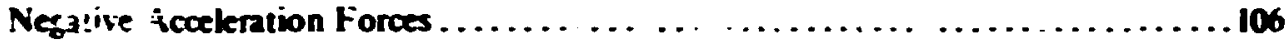

12.4 Apferidix U: Computer Prugram to Cahuble :ivie Mrop

Negirive Acrelera:ion Forces . . . . . . . . . . . . . . . . . . . . . . . . . . 117

12.5 Appendex E : Report of Special Inspection of Cirden Canier

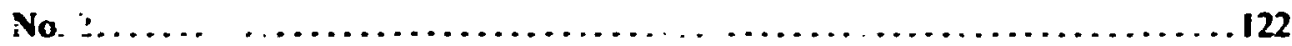

12.6 Ap.en ix F : Upaing Procedures Applicethe to the Canden

Carrier 1.. . . ......................................... 125

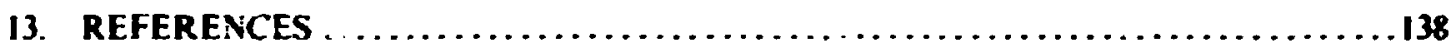


SAFETY ANALYSIS REPORT FOR PACKAGING (SARP) OF THE.

OAK RIDGE NATIONAL LABORATORY GARDEN CARRIER NO. 2

\author{
B. B. Klima, L. B. Shappert, R. D. Sengren, and W. D. Box
}

\begin{abstract}
An analytical evaluation of the Oak Ridge National Laboratory Ganden Carrier No. 2 was made to demonstrate its compliance with the regubtions governing off-site radioactive material shipping packages. The evaluation encompassed five primary catceories: structural integrity, thermal resistance, radiation shielding. nuclear criticality safety, and quality aseurance. The results f the evaluation show that the cast complies with the applicable regulations.
\end{abstract}

\title{
1. INTRODUCTION
}

The ORNL Garden Carner No. 2 was developed at the Oak Ridge National Lahoratory. The design was analyzed in $1969^{\prime}$ and reevaluated in 1975 to demonstrate compliar.se with the regulaticns. The results of the analyses are presented in Sects. 2 through 10 of this report. The package was inspected to ensure that it was built in accordance with the drawings presented in Afpendix A.

The primary use of the container is to provide shielding, impact resistance. and thermal resistance for its contents during both normal transport and hypothetical accident conditions. The package is designed to ship large quantities of fissile and radioactive materials as solids. The package is authorized to be shipped by motor vehicle and rail. It complies with the Nuclear Regulatory Commission (NRC) regulations contained in the Codp of Federal Regulations, Title 10, Part 71, ${ }^{2}$ DOE Monual Chapter 0529, and all Immediate Action Directives (IAD) in effect as of this report date. The cask also complies with U. S. Department of Transportation regutations published in the Code of Federal Regulations. Title 49. Part 173."

Calculations, engineering logic, and all related documents that demonstrate compliance with specifications are presented in subsequent sections of this report. Copies of the approval documents are reproduced in Appendix B.

The Garden Carrier No. 2 was fabricated and assigned the Depariment of Transportation Special Permit No. 6088. An interin certificate of compliance has been issued by the Atomic Enercy Commistion (eee Appendix B). The cask, as it was used, is shown in Fig. 1, mounted and ready for shipment on its stid.

Previous analyses have indicated the need for a fire shield (see Fig. 2) to prevent the lead shielding from melting in the hypothetical accident sequence. This fire shield has been designed. and this analysis is based on its use. 
BLANK PAGE 


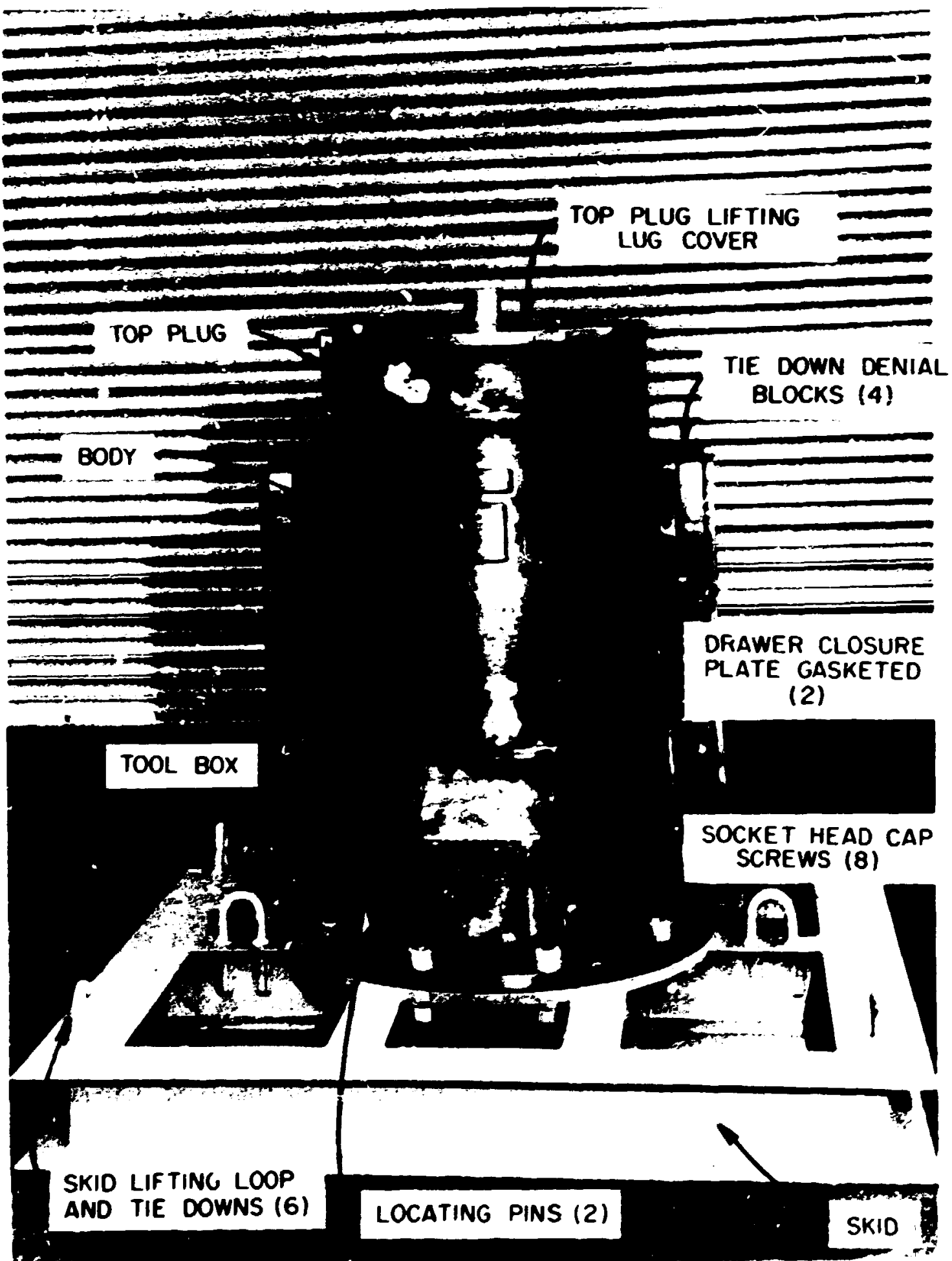

F18. 1. Garden Carrier Ro. 2 (as originally used). 


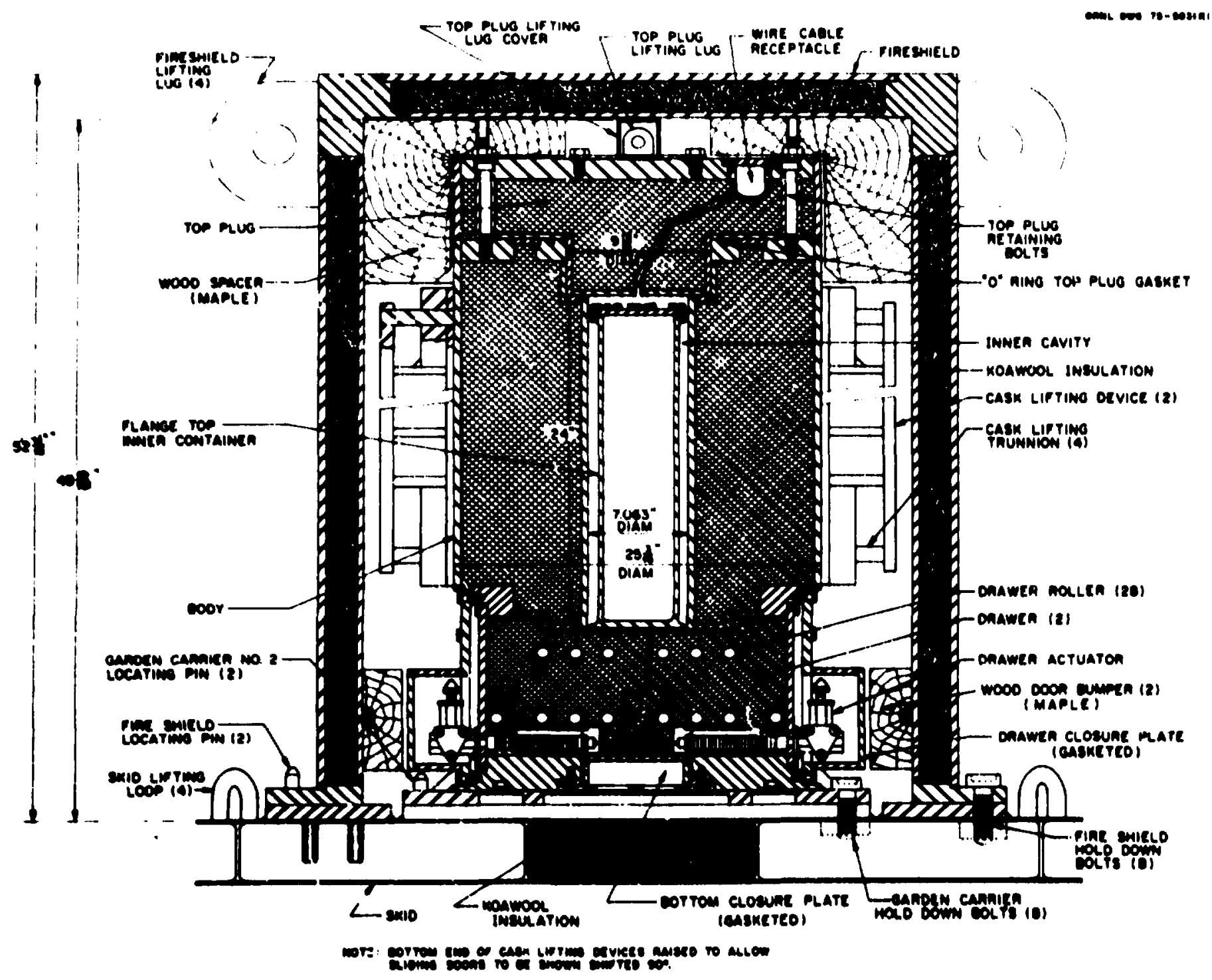

F1g. 2. Section of Garden Carrier No. 2 with fire shield showing components. 


\subsection{Description of the Pactage}

The ORNL Garden Carrier No. 2 (see Figs. 1 and 2) is a lead-filled 304L stainkess steel weldment, cylindrical in shape, and measuring approximately 25 in. OD by 45 in. inigh. The inner cavity is 7.065 in. ID by 24 in. high. It provides approximately 8-3:16 in. of lead shickding. It has a 43-in.-OD by 51-11/16-in.-high fire shield that fits over the cask and is secured in place when the cask is shipped. The fire shield has a 1/2-in.-thick steel outer shell and a 3/16-in-thict inner stell with the void filled with 2 in. of Kaowool*, a ceramic íber insulation material. The assembly consists essentially of the following elements: cask body, cask top plug, two drawers, four cask closure plaies, fire shiekd, and skid.

The ask body has an outside shell made from $1 / 2$-in-thick 304L stainless steel plate rolled to form a cylinder $25-3 / 16$ in. in diameter. The bottom of the body is a 2-1:2-in.thick 304L stainless sted ptate. This phate forms the bottom of the stepped rectangular opening in which the two drawers slide. The sides of the drawer openings are 1-in.-thick plate whik the top is $3 / 8$ in. thick. The top plate is $1-1 / 2$-in.thick $304 \mathrm{~L}$ stainless steel with a 10 -in.-diam by 4in.-deep offset for the top plug. The sides and bottom of the offset are made from 38 -in. phate as is the central tube, which forms the wall of the inner cavity. The inner cavity is 7-1 16 in. ID by 24 in. long from the end of the top plus to the top of the drawers.

The body is welded to a I-in.thick base plate which is 32 in. in diancier. In addition, 14 triangular gussets, $1 / 2$ in. thick by $3-3 / 8$ in. on the side, are welded to the body and base plate and strengthen the base-plate flange. The i-1/2-in. top plate of the body has two 2-in.-diam lead filling holes which are closed by $3 / 8$ in.-thick plate welded after the lead filling. On the outside of the body and running vertically on each side are two lifting ribs. Each lifting rib has . 2 2-in.-diam lifting trumion top and bottom.

The plug has a 1/2-in.-thick plate cylindrical outer wall. The top phte is 1-1/2 in. tinick and the bottom is 3/8 in. thick. The 4in. top plug extension is 9-15/16 in. in diameter. The lead was poured through two 2 -in.-diam holes in the extension face. The plug is held on the body by 12 socket-head cap screws, each $3 / 4$ in. in diam by 6 in. long (16NF-2). Each of the screw heads is recessed in the plug. and the body of the bolt passes through a stainless skeve that is seal-welded top and bottom to the plug. The plug is sealed to the body by a 19-in.-OD by 18-1/2-in.-ID by 1/4-in.-diam neoprene " $\mathrm{O}^{-}$-ring recessed in a groove in the top of the body. The plug has a wire cable receptack and an offset $1 / 2-$ in.-OD by $1 / 8$ in.-wall-tubing interconnection to the center of the plug. The receptacle is fur storing wire cable used to raise the inner container into and lower it out of the inner cavity. Thz receptack is closed by a 1/2-in.thick 304L stainless steel cover and is sealed by a 1/16-in.thick neoprene gasket. The recepracke cover is held in place by six 1/4-in. diam by 3/4-in.-long (20 NC-2) bolts. The plug has the following directive engraved on its top: "this cover must be on carrier and seal wired in place, except when using top plug lifting lug." The top cover is fabricated from $1 / 8$-in.-thick aluminum and is used to deny use of the plug lifting lug to lift the cask; it is held to the plug by two 3/4-in. by 1-in.-long (10 NC-2) hex-head head bolts, the heads of which are drilled for sefety wires.

Two lead-filled drawers that overlap when closed are held in the closed position by eight 3/8-in. by 3/4-in. long (16 NC-2) hex-head cap serews in each drawer. The drawers each move back and forth on $14 \mathrm{cam}$ rollers. The drawers are moved by an angle drive attached to the

* Product of Babcock Wilcox. 
outside of the drawer which drives a screw (1-in. by 8 .C-2) on which the drive nut rides. The drive nut is held in place on the bottom of the drawer opening by two dowetended socket-head cap screws. each sealed by a stato-seal. Each of the drawers is covered during shipment by a stainless steel closure plate: this plate is secured by 20-1 2-in.- by 1-1 4-in.tong (13 NC-2) socket-head cap screws and sealed by a 1. 16-in.-thick neoprene gasket.

The entrance to the bottom of the Garden Carrier through the base phate is sealed by a bottom closure plate held in place by eighi 12 -in.- by 1-in.-long (13 NC-2) hex-head cap screws and sealed by a I 16-in.-thick neoprene gasket.

The Garden Carrier No. 2 is located and oriented on the skid by two locating pins. It is secured to the skid by eight 1-I 2-in.- by 3-1 2-in.-kng (6 NC-2) sockethead cap screws made from 4140 annealed steel. Special 4140 annealed steel bolts are specified on the drawings: however. calculations prove that any steel bolt the proper size will be satisfacton:

The fire shield rests on a I-in.-thick steel piate welded to the inp of the skid. The fire shield has a 1 4-in.-thick inner shell which is welded to a ring which bolts to the plate mounted to the skic. Both the side inner shell and top ( 38 in. thick) are welded to a heary steel ring at the top. Two inches of Kaowool insulation is applied to the outside of the inner plate. and it is held in place by clips secured on 6-in. centers. A 12 -in. plate forms the outer shell of the fire shield.

An annular ring of mapie wood tills the gap between the top of the Garden Carrier Yo. 2 and the fire shield. The clearance between the wood ring and the cask is 18 in. radially. but it centacts the cask vertically. Two maple pads are fastened to the inside of the fire shield in line :with the drawer cover plates to prevent displacement of the drawers in the event of a caiastrophic accident. A 18 -in. clearance is found between the face of the drawer cover and the wooden pad. The fire shield has four lifting lugs. which are also used so tie the cask down to the vehicle by four cables. Thr skid is also tied to the vehicle with four tie-down cables fastened to the skid tie-down loops. The fire shield is oriented on the skid by two locating pins and secured by eight 1-I 2-in.- by 3-1 2-in.-long (6 NC-2) socket-head cap screws made from the same steel as used to bolt the cask to the skid.

The shipping skid is 5 ft by 5 ft, by 6 in. high. The skid has four 1-1 2-in.diam tie-down loops and has a 32-in.-diam plate matching the closure of the hottom of the cask. The skid has a Kaowool-insulated area directly under the cask. It also has a built-in locked inol hox. which carries needed wrenches and other supplies.

The primary line of containment is the gasketed inner container. A secondary line of containment is considered to be the cask cavity that is sealed by five gasketed closures. three on the bottom and two at the top

The Garden Carrier No. 2 weighs 8440 lb alone. The complete package. including the skid. fire shield. inner container, and contents, weighs $12.400 \mathrm{lb}$.

\subsection{Contents of the Package}

The ORNL. Garden Carrier No. 2 is used to ship large quantities of fissik and radioactive materials (not otherwise specified) in the form of unirradiated or irradiated fucl elements. contained sections of fuel elements. solid fission products, and waste products. The maximum 
thermal decay energy for shipments is $100 \mathrm{~W}$. The fissite content is limited to not more than $500 \mathrm{~g}$ of ${ }^{233} \mathrm{U}, 350_{\mathrm{g}}$ of ${ }^{233} \mathrm{U}$ or plutonium, or 350 of any combination thereof.

Solids are contained in a special inner containet (see Sect. 8). Shipments are made as Fissile Class 1 and are authorized to be transported by motor vehicke and rail. Any shipment will be limited to a source strength such that the radiation kevels will not exceed those specified in the DOT regulations.'

\section{STRUCTURAL EVALUATION}

The package complies with the structural requirements of the regulations (see Sects. 2 through 6). The calculations, test results, and engineering logic presented in the following sections demonstrate compliance with these performance criteria. The effects of both normal transport and specified accident conditions on the structural integrity of the package are considered.

\subsection{Structural Design}

The as-built drawings for the Garden Carrier No. 2 and all other applicable drawings are shown in Appendix A. The principal structural members of the cask are: (1) cask body, (2) top plug, and (3) two drawers. The welds of each of these fabricated pieces was checked by a dye-penetrant test and $x$-rayed. The weldment was then pressure-tested and filled with lead. Each member was filled slowly and the body heated at the time of filling. The heated zone of the cask body was raised as the level of the lead was raised so that (1) solidification was from the bottom, and (2) the solidifying metal was covered with molten metal until the top was reached. After finishing the filling operations, each hole was closed with a plug. When this was completed, the member was then machined to the required dimensions. The top plug and the drawers were similariy constructed.

\subsection{Cask Weight}

The weight of the package, its parts, and the contents are shown in Table 1.

\subsection{Mechanical Properties of Materials}

The mechanical properties of lead, carbon steel, and stainless steei are summarized in Table 2. The properties of the wood used in the fire shield are given in Table 3. 
Table 1. Weight of components of Garden Carrier No. 2

\begin{tabular}{lr}
\hline \multicolumn{1}{c}{ Component } & $\begin{array}{r}\text { Weight } \\
(1 \mathrm{~b})\end{array}$ \\
\hline Cask body & 6,530 \\
Top plug & 1,170 \\
Draver assembly (two drairers) & 670 \\
Drive unit covers & 70 \\
Skid & 1,190 \\
Fire shield & 2,600 \\
Inner container & 40 \\
Contents & 130 \\
& Total \\
\hline
\end{tabular}


Table 2. Hechanical properties of lead, ald steel, and stainless steel

\begin{tabular}{|c|c|c|c|c|}
\hline Properties & Sybol & $\begin{array}{c}\text { Stainless } \\
\text { steel } \\
3041 \\
\end{array}$ & $\begin{array}{c}\text { Lead } \\
\text { (solid) }\end{array}$ & $\begin{array}{l}\text { Low } \\
\text { carbon } \\
\text { steel } \\
\end{array}$ \\
\hline \multicolumn{5}{|c|}{ Static properties } \\
\hline Tensfle yield stress, psi & $\sigma_{y}$ & $30 \times 10^{3^{a}}$ & $2000^{b}$ & $30 \times 10^{3}$ \\
\hline Allowable shear stress, psi & $\tau_{\mathbf{a}}$ & $15 \times 10^{3 c}$ & - & $15 \times 10^{3^{c}}$ \\
\hline U1timate shear strength, psi & $\tau_{\mathbf{u}}$ & $61 \times 10^{3^{a}}$ & $1825^{b}$ & $45 \times 10^{3}$ \\
\hline Young's nodulus, psi & $\mathbf{E}$ & $30 \times 10^{6}$ & $2 \times 10^{6 b}$ & $29 \times 10^{6}$ \\
\hline Poisson's ratio & $v$ & $0.3^{b}$ & $0.40^{b}$ & - \\
\hline Welght density, $1 \mathrm{~b} / 1 \mathrm{n} .^{3}$ & $\mathbf{r}$ & 0.283 & $0.41^{b}$ & 0.283 \\
\hline $\begin{array}{l}\text { Thereal expansion } \\
\text { coefficient, }{ }^{\circ}{ }^{-1} \\
\text { Helting point }\end{array}$ & $\mathbf{a}$ & $\begin{array}{c}9.6 \times 10^{-6} \\
-\end{array}$ & $\begin{array}{l}16.3 \times 10^{-6} \\
625^{\circ} F^{b}\end{array}$ & $\begin{array}{c}6.5 \times 10^{-6} \\
-\end{array}$ \\
\hline
\end{tabular}

Dynamic properties

Specific energy, in. $-1 \mathrm{ib} / \mathrm{in.} 3$

$S \min 10 \times 10^{4} \mathrm{~d}$

$10 \times 10^{4} d$ $26 \times 10^{4}$

\footnotetext{
The International Nickel Company, Inc., Mechantcal and Physical Propertles of Austenitic Chromium-Mickel Stainless Steel at Ambient Temperatures, 963.

betals Handbook, 8th ed., Vo1. 1, Properties and Selection of Metals, American Society For Metals, Novelty, Oh1o, 1961.

$c_{50 \%}$ of tensile yield stress.

dJ. H. Evans, Experimental Study of the Stress-Strain Properties of Cask Materials Under Specifled Impact Conditions, USAEC publication CONF-740901-P1, 232-44 (1974).
} 
Table 3. Properties of maple moda

Compressive strengih, ultimate, with grain

Compressive strength elastic linit, with grain

Compressive strength elastic limit, across grain

Shear strength, with grain

Density
7830 psi

5390 psi

1810 psi

2430 psi

$0.0251 \mathrm{~b} / \mathrm{in}^{3}$

${ }^{a_{R}}$. J. Roark, p. 417 (Table XIX) in Formulas for Stress and Strain, 4 th ed., McGraw-Hill, ilew York, $196 \overline{5 .}$ 


\section{GENERAL STANDARDS FOR ALL PACKAGES}

The general stadards for all packaging include the chemical and galvanic reactions of the materials composing the package. cicsure of the package. and the lifting and tie-down devices for the package.

\subsection{Chamial and Galranic Reactions}

The package is fabricated from stainless steel and lead. The lod is completely encased in staialess steet so that any contents of the pactage would contact stainless steel rather than lead.

The fiscrile and radicactive contents of the pactage are housed in inner containers (see Sece. 8). Any liquid contents will be contained in polyethylene or stainless steel bottles inside these inner containers.

Experience and inspection have indicated no chemical, galvanic, or other reaction betwe:n the chading and the containers, or between the containers and their contents.

\subsection{Packagi Cousure}

The standards specify that the pactage shall be equipped with a positive closure that will prevent inadvertent opening.

The pactage, when shipped, is completely covered by the fire shield, which is fastened to the skid by eight 1-1/2-in. bolts. This fire shield prevents the cask from being inadvertently opened.

\subsection{Package Lifting Devices}

The regulations require that any system of lifting devices that is a structural part of the package shall be capable of supporting three times the weight of the loaded package without generating stress in any material of the package in excess of its yield strength.

The Garden Carriet No. 2 has three separate systems of lifting devices that can be used to lift the package: (I) the four lifting trunnions, which are a pan of the cask itself and are used to handle the cask; (2) the four lugs located at the top of the fire shield. which are normally used to lift the fire shield and package and to tie the package to the vehick; and (3) the four loops located on the skid, which are also used to tie the package to the vehick. A fourth device, which is the top plug-lifting lug. will not be considered as a cask handling device since at all times, except when removing the top plug. it will be enclosed by a protective cover that is held in place by two wired and sealed bolts. It is necessary to demonstrate that the first three of these lifting systems are capable of meeting the requirements. 


\subsection{Garden Carrier Vo. 2 lifing Irunnions}

There are four 2-in-diam lifting tninnions. one at ear. of the two lifting ribs located on the side of the cask. These trunnions and lifting ribs are shown in Fig. 3: the body of the cask has been filled with lead. but final machining has not been done. The lifting rib has a 3 4-in.thick by 3-in.-wide outer plate. Normally two or all four of these lifting trunnions will be utilized at once. For computational purposes, use st the two top trunnions will be assumed.

The computational model used is shown in Fig. 4. The apprsach used to amatyze this trunnion is similar to that for a propped beam. (See Ref. 6 for derivation ef equations.)

The deflection. $\angle$ of the inrestrained end [see Fig. $4(a)$ ] of the beam (2-in.-diam rod) is numerically equal to the elastic elongation of the 3 4-in. by 3 -in. by 3-1 2-in. bar securing the end of the trunnion. An expression for the elongation of the bar, $\Delta$ may be weritten as follows:

$$
\Delta=-R L A E=-R(3.5)\left(2.25 \times\left(30 \times 10^{4}\right)=-5.19 \times 10^{-4} R\right. \text { in.. }
$$

where

$$
\begin{aligned}
& R=\text { reaction, } 16 . \\
& L=\text { length bar, } 3.5 \mathrm{in} . \\
& A=\text { area of bar. } 2.25 \text { in. }^{2} . \\
& E=\text { modulus of electricity (see Table } 2 \text { ). } 30 \times 10^{\circ} .
\end{aligned}
$$

The beam may be considered as two beams, loaded as shnwn in Fig. 4(b). and by the principle of superposition.

$$
\Delta=\Delta_{R} \cdot \Delta_{p} \text { with ! being positive. }
$$

As defined in the regulations. the cask lifting device must be capable of supporting three times the weight (3Y) of the cask and its contents (See Table I) without generating stresses in excess of the yield strength of the material. The total weight of the cask and contents is 8610 Ib. The lcading or force. P. is calculated:

$$
P=F \Psi N=3(8610), 2=12,915 \mathrm{lb} \text {. }
$$

where

$$
\begin{aligned}
& F=\text { facter required by regulations, } 3 . \\
& \mathbb{W}=\text { weight of carrier (see Table } i \text { ). } 8610 \mathrm{lb} . \\
& N=\text { number of irunnions used. } 2 .
\end{aligned}
$$


Oame paroto-seses A

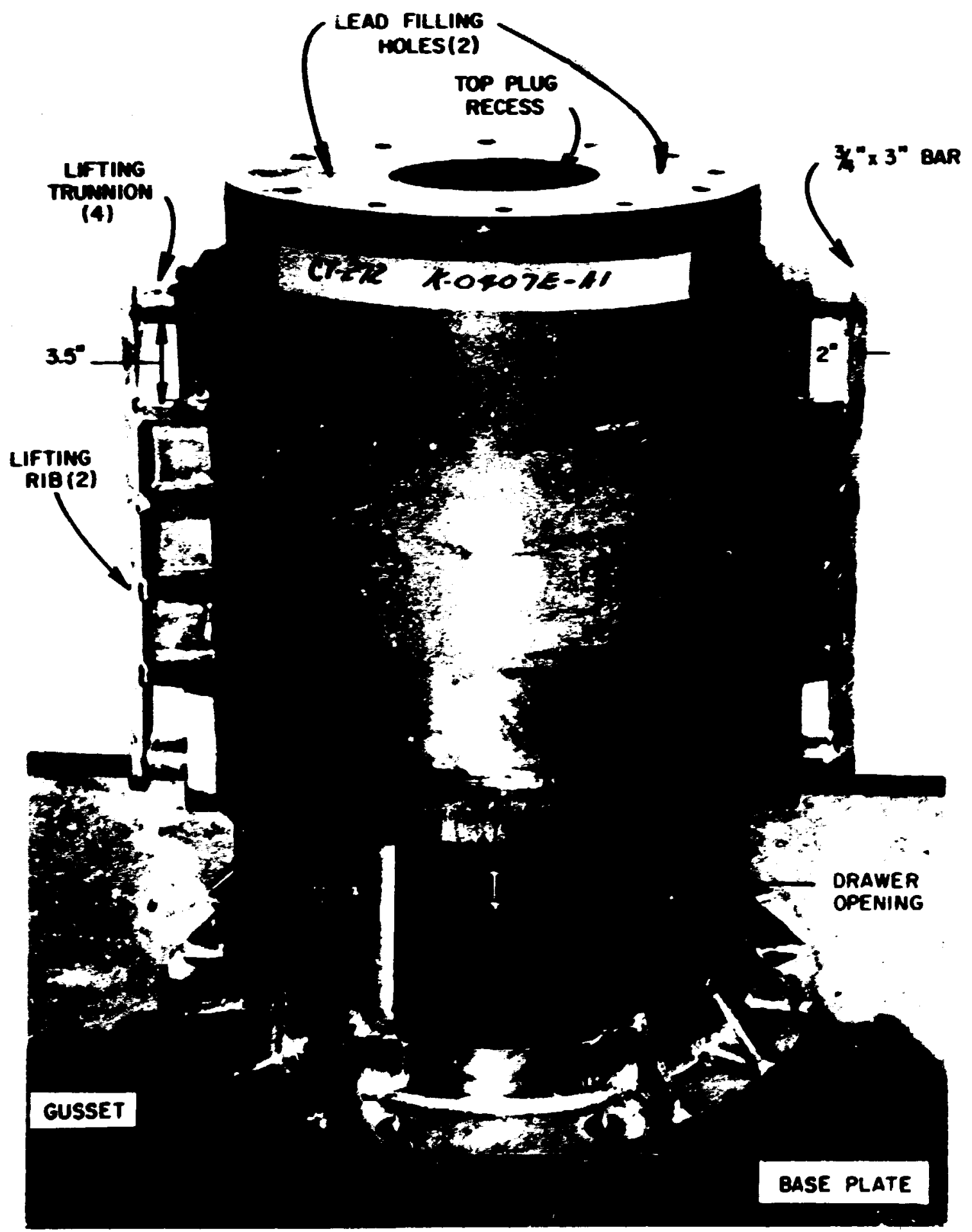

F1g. 3. Body of Garden Carrier 10. 2 after it had been lead filled and prior to machining. 


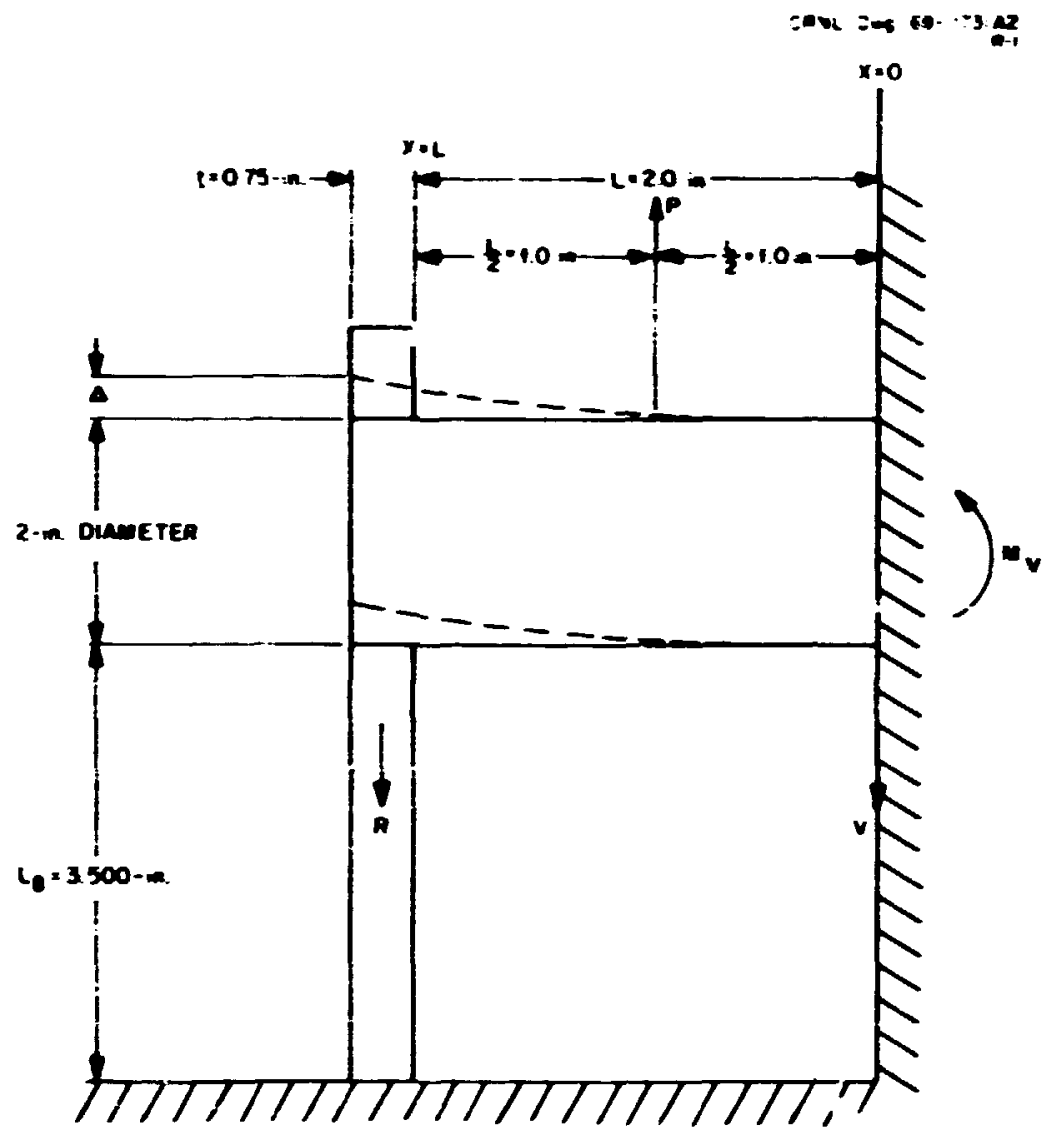

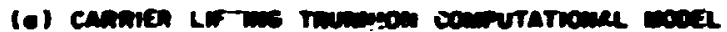

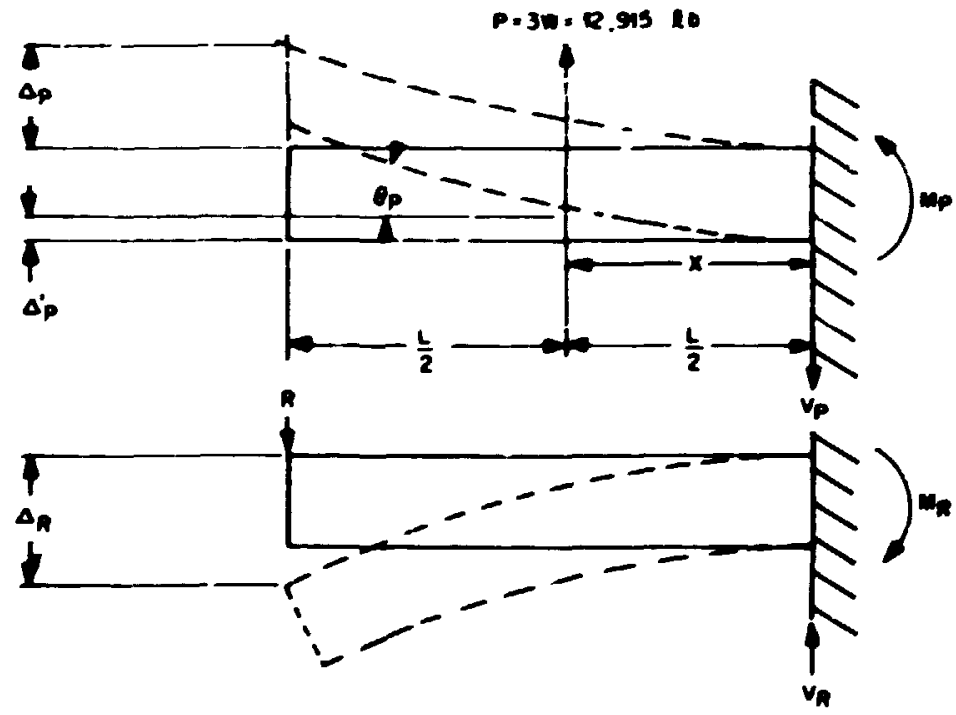

(b) OeAn supenposinom orachan

F18. 4. Hodel of cask lifting trunnion and beam superposition diagran. 
The deflection of the beam $\left(\Delta_{H}\right)$ at the end is given by

$$
\Delta_{p}=5 P^{3} / 48 E I
$$

The deflection doe to the reaction. R, at the cad of the beam may be calcubted as follows:

$$
\Delta_{\mathbf{R}}=\mathbf{R L} \mathbf{L}^{\prime} \text { 3EI. }
$$

- Subctitutine Eqs. (1), (4), and (5) into Eq. (2), it becomes

$$
-5.19 \times 10^{-0} \mathrm{R}=\left(\mathrm{RL}^{3} ; 3 E \Lambda\right)-\left(\mathrm{PPL}^{3} ; 4 \mathrm{ES}\right)
$$

The moment of inertin is computed by the iollowing equation:

$$
t=\pi \pi^{4} d=\pi(1)^{4}=\pi 4 \text {. }
$$

whese

$$
r=\text { radius of trunnion, } I \text { in. }
$$

The value, R, may be determined by substituting the following values in Eq. (6):

$$
\begin{aligned}
& {\left[R(2.0)^{3}: 3\left(30 \times 10^{\circ}\right) \pi 4\right]-\left[5\left(12,920 \times(2.0)^{3} .48\left(30 \times 10^{\circ}\right) \pi 4\right]+5.19 \times 10^{-8} R=0\right.} \\
& R=2770 \mathrm{ib} .
\end{aligned}
$$

where

$L=$ kength trumion, 2 in.

The shear (V) is colculated (see Fig. 4) as foilows:

$$
V=P-R=12.920-2770=10.150 \mathrm{lb} .
$$

The moment (Mv) is calculated (see Fig. 4) assuming $1=+$.

$$
\begin{aligned}
\mathbf{M}_{\mathbf{v}} & =\mathbf{R L}-\mathbf{P} \mathbf{L} / 2 \\
& =2770(2.0)-12.920(1.0) \\
& =-7380 \mathrm{lb} .
\end{aligned}
$$

The load diagram for the cask lifting trunnion is shown in Fig. 5. 
ORNL DWO $68 \cdot 11732 A 2$

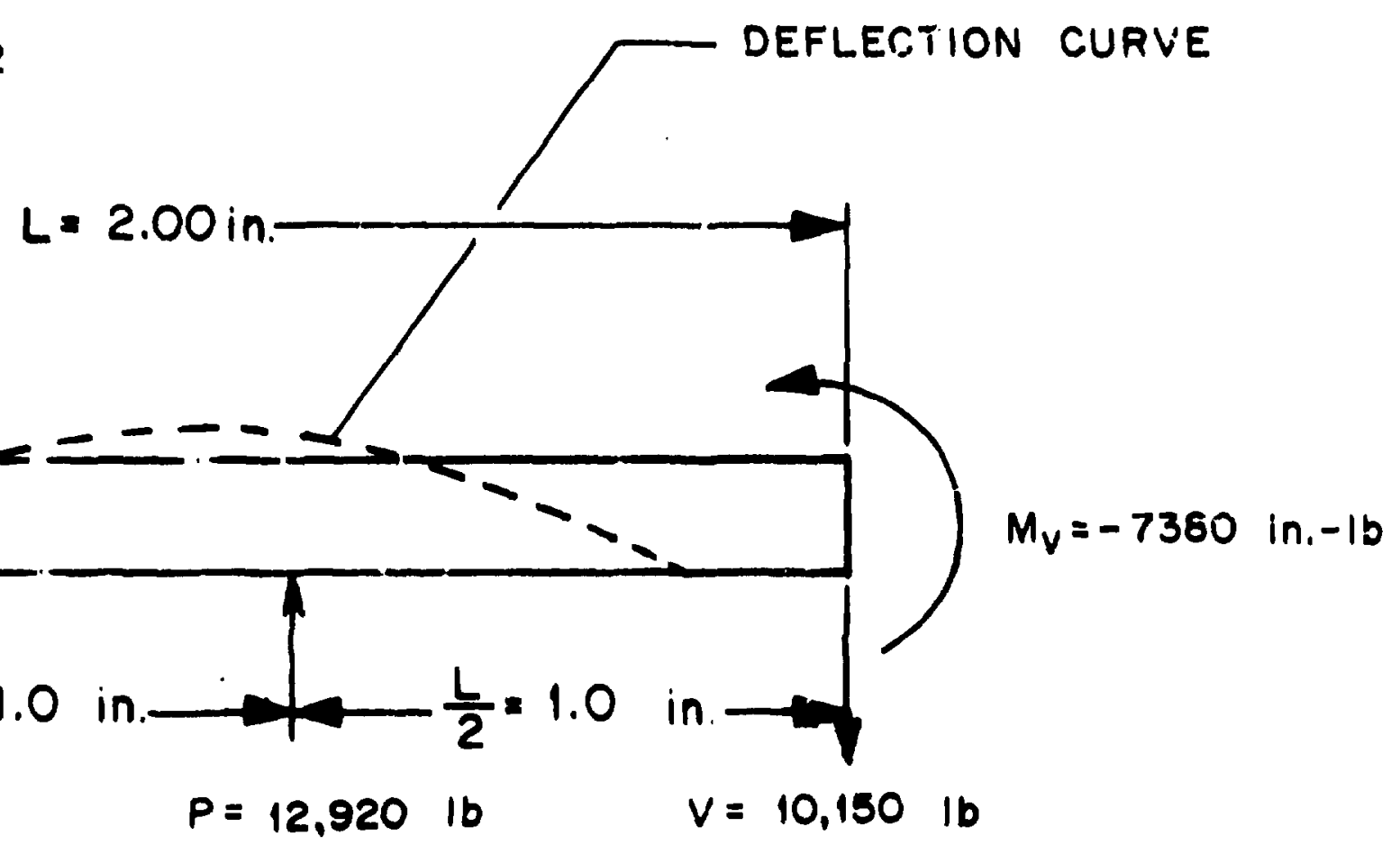

Fig. 5. Load diegram tor cask lifting trunnion. 
The maximum beading stress, Sn occurs at the poiat of maximam moment. $X=0$, and is Cakcubied as follows:

$$
S_{0}=\text { Mrc } I=7300(1):-4=9400 \mathrm{psi}
$$

where

$c=$ distance from centroidal axis to extreane forer, I in.

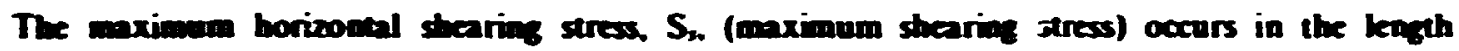
from $X=0$ to $X=L, 2$ at the newirl axis of the section where the bending stress is zero.

$$
S_{s}=4 V_{i} 3 A=4(10.150), 3(3.14)=4310 \text { psi. }
$$

where

$$
A=\text { area of trumion. } 3.14 \mathrm{in}^{2} .
$$

The stres in the lifting trunaion is less than the albowable stress (see Table 2). therefore. The lifting truanion meets the requirements of the rezulations.

Should the liftias tunnion fail due to excessive bad. the mode of filure would be by beading: however, containment would not be lost nor would the ability of th: package to meet aber requirements be impaired.

\subsubsection{Fire shield liffing by}

Four lifting ligs are located at the lop of the fire shield (see Fig. 6). which could be used to lift the Garden Carrier No. 2 Probably two nr all four of these lifting lugs would be used at one time to distribute the load during a lifting operation. This analysis. however. has postulated the use of only one lifing lus

Each lifing lug is a 2-1 4-in.thict mild steel bar with a 3.5-in.diam hole in its center. Each lifting lug is welded to the fire shield by 30 in. of $5 / 8$-in. fillet weld.

The following amalysis is based on equations given by Roart' that an bie used to predint seress concentration factors found in the analysis of curved beams. For a value of $R / c=4.0,2.25=1.80$. where $R$ is the redius of curvature masured to the centroid of the section and $c$ is defined below, a table supplied by Roark' shows the following rebtionships:

and

$$
k_{\mathfrak{r}}=1.63=S, S
$$

$$
k_{0}=010=S_{n}: S
$$


ORNL-DWG 75-529:

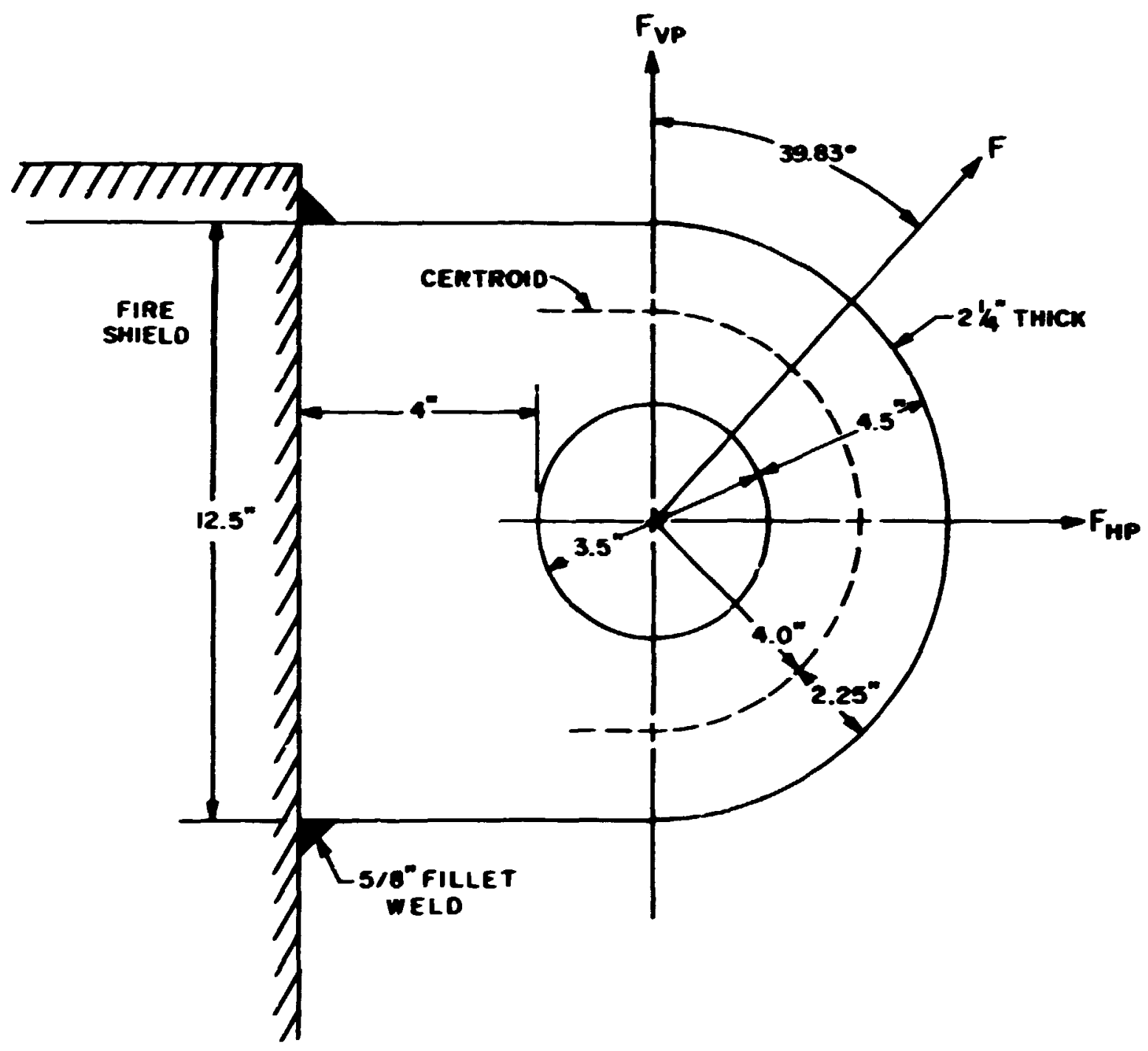

Fig. 6. Fite shield lifting lug. 
where

$k=$ the stres concentration factor.

S. = actual stress in extreme forer on comave side.

S. = actul stress in extreme fiber on convex side.

$S=$ unit stress in correspondine fover as computed by ordinary Rexure formub for a straight beam.

$$
S=M c_{i} I \text {. }
$$

where

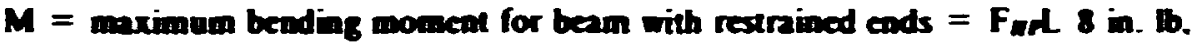

$$
\begin{aligned}
& c=\text { distance from centroidal axis to extreme fiber, } 2.25 \mathrm{in} . \\
& I=\text { moween of inerin, bd'/12 in.". } \\
& L=\text { leagh of bem. } 8.0 \mathrm{in} . \\
& F=\text { force. } 3 Y \text {. b. } \\
& F_{w r}=F\left(\sin 39.83^{\circ}\right) . \mathrm{b} \text {. } \\
& F_{n p}=F\left(\cos 39.83^{\circ}\right), 8 . \\
& \text { YI = Wcight of pactage. } 12,400 \mathrm{db} \text {. } \\
& d=\text { depth of beam, } 4.5 \text { in. } \\
& b=\text { width of beam. } 2.5 \mathrm{in} .
\end{aligned}
$$

Subsituting these values and the dimensions shoren in Fig. 6 .

$$
\begin{aligned}
F & =3(12.400)=37,200 \mathrm{db} \\
F_{m p} & =37.200(0.640)=23,800 \mathrm{lb} \\
F_{u p} & =37,200(0.768)=28.600 \mathrm{lb} \\
M & =(23,800 \times(8.0) / 8=23,800 \mathrm{in} .1 \mathrm{~b}
\end{aligned}
$$




$$
\begin{aligned}
& I=(2.5 \times 4.5)^{\prime} 12=18.98 \mathrm{in}^{\circ} \\
& S=(23.800 \times 2.25) 18.98=2820 \mathrm{psi} .
\end{aligned}
$$

Therefoce. the stress on the extreme fibers is calculated by the following:

$$
S=k S=(1.63)(2820)=4600 \mathrm{psi}
$$

and

$$
S_{.}=k S=(0.70 \times 2820)=1900 \text { psi. }
$$

Thus the stresses in the extreme concave fiber and in the extreme convex forer are less than the tensik yietd strength of the mild sted material (sece Table 2). Hence. the design meets the requirements.

The tension in the weld (o-) is determined by the following equation:

$$
\sigma_{\text {. }}=F_{m p}(s)=23.800301581=1270 \text { psi. }
$$

where

$$
\begin{aligned}
& L=\text { kength of weld. } 30 \mathrm{in} . \\
& s=\text { size of weld. } 58 \mathrm{in} .
\end{aligned}
$$

The shear in the weld $\left(r_{-}\right)$is determinad

$$
I_{0}=F_{w r} w(s)=28.60030(58)=1530 \mathrm{psi} .
$$

The maximum stress in the weld is determined

$$
\begin{gathered}
\sigma_{m e}=\sigma_{-} 2 \pm\left[\left(\sigma_{-} 2\right)^{*}+\left(i_{-}\right)^{Z}\right]^{:}= \\
12702 \pm\left[(12702)^{*}+(1530)^{3}\right]=2290 \text { psi. }
\end{gathered}
$$

The maximum stress in the wald is helow the allowable kevels (see Table 2).

Should the fire shield lifting lug fail due to excessive load. failure would be by hending: however. containment would not be lost. and the ability of the package to meet other requirements would not be impaired. 


\subsubsection{Skid loops}

Four lifting loops are located or: the skid (see Figs. 2 and 7) which could be used to lift the Garden Cartier No. 2. Since these lifting loops are well below the center of gravity. if they are used, all four will be needed simulaneously and equally loaded. These conditions will serve as the basis for this amalysis.

Each lifting loop is a 1-1/2-in.-diam mild steel loop, as shown in Fig. 7.

The following analysis is based on equations given by Roark' that can be used to predict stress concentration factors fourd in the analysis of curved beams. For a value of $R / c=2.0: 0.75=2.67$, where $R$ is the adius of curvature measured to the centroid of the section and $c$ is defined below, a table supplied by Roart ${ }^{7}$ shows the following:

$$
\mathbf{k}_{\mathbf{t}}=1.43=\mathrm{S}_{i} \mathrm{~S}
$$

and

$$
\mathbf{k}_{\mathrm{o}}=\mathbf{0 . 7 6}=\mathbf{S}_{\boldsymbol{o}} / \mathrm{S}
$$

where

$k=$ the stress concentration factor,

$S_{i}=$ actual stress in extreme fiber on concave side,

$S_{v}=$ actual stress in extreme fiber on convex side,

$\mathbf{S}=$ unit stress in corresponding fiber as computed by ordinary flexure formula for a straight beam.

$$
\mathbf{S}=\mathbf{M c} / \boldsymbol{l}
$$

where

$M=$ bending moment, $F_{v} l / 8$ in.-lb,

$c=$ distance from centroidal axis to extreme fiber, 0.75 in.,

$I=$ moment of inertia, $\pi r^{4} / 4$,

$L=$ length of beam, 4.0 in.,

$F_{v}=$ force $3 \mathbf{W} ; 4,16$,

W = weight of package, $12,400 \mathrm{tb}$ (see Table I),

$r=$ radius of beam, $0.75 \mathrm{in}$. 


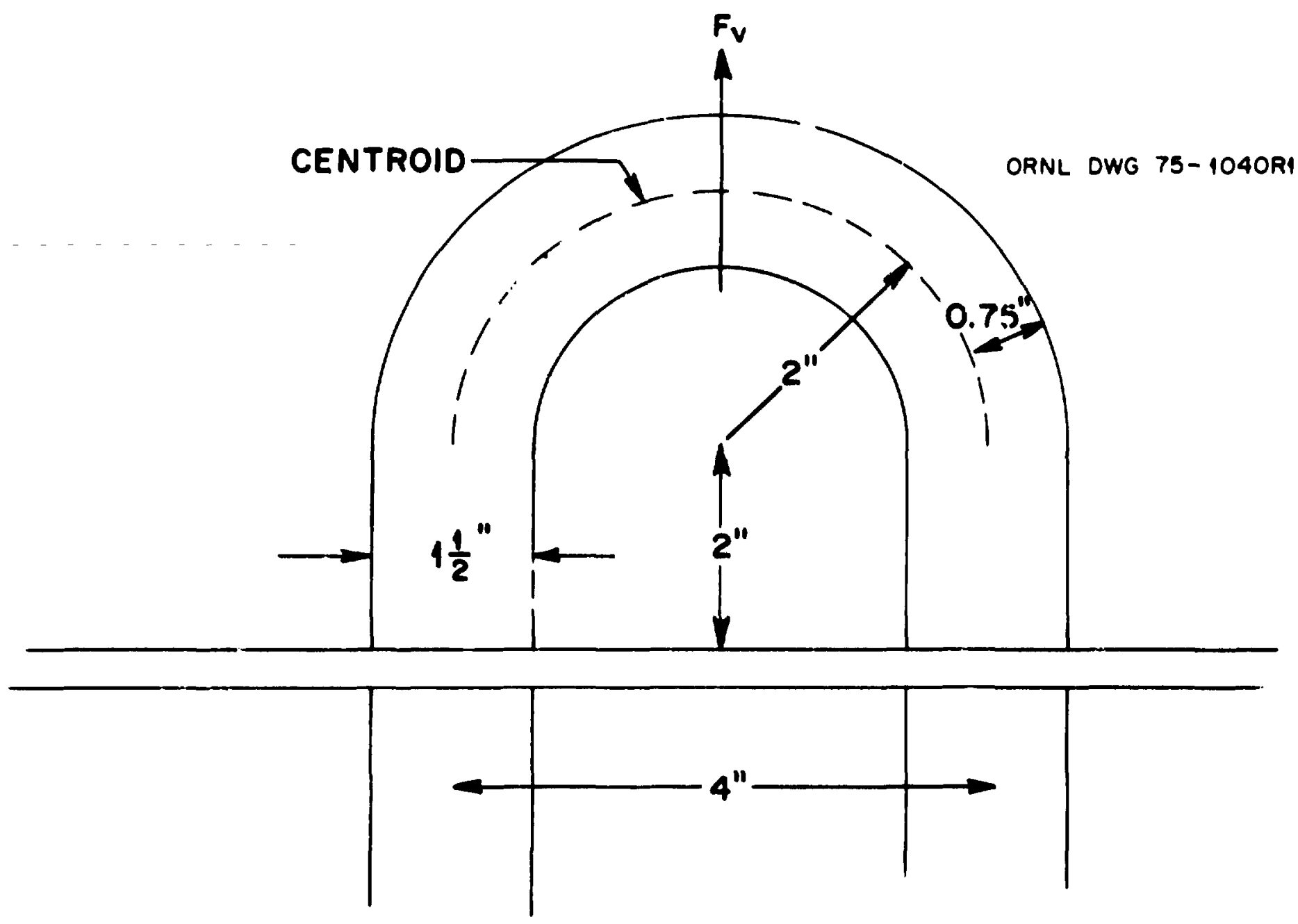

F1g. 7. Skid lifting loop. 
Substituting these values and the dimensions shown in Fig. 7.

$$
\begin{aligned}
& M=(9300) \times 4.0) / 8=4650 \mathrm{in} .-1 \mathrm{~b}, \\
& F_{v}=3(12,400) / 4=9300 \mathrm{lb}, \\
& I=\pi(0.75)^{4} / 4=0.249 \mathrm{in} . \\
& C=(4650)(0.75) / 0.249=14,000 \mathrm{psi}
\end{aligned}
$$

Therefore,

and

$$
S=k S=(1.43)(14,000)=20,000 \mathrm{psi}
$$

$$
S_{\odot}=k_{\infty} S=(0.76)(14,000)=10.640 \mathrm{psi}
$$

Thus the stresses in the extreme concave fiber and in the extreme convex fiber of the skid lifting loops are less than the tensile yield strength of the mild steel material (see Table 2).

The tension in the weld is determined in the following manner.

where

$$
\sigma_{w}=F_{v} / L(s)=9300 / 9.42(0.5)=1970 \mathrm{psi},
$$

$$
\begin{aligned}
& L=\text { length of weld, } 9.42 \mathrm{in} . \\
& s=\text { size of weld, } 0.5 \mathrm{in} .
\end{aligned}
$$

The shear in the weld is determined by the equation:

$$
T_{w}=F_{v} / L_{s}=9300 ; 9.42(0.5)=1970 \text { psi. }
$$

The maximum shear in the weld is found by the following equation:

$$
\sigma_{\max }=\sigma_{w} / 2\left[\left(\sigma_{m} / 2\right)^{2}+\left(\tau_{m}\right)^{2}\right]^{12}=1970 / 2 \pm\left[(1970 / 2)^{2}+(1970)^{2}\right]^{12}=32100 \mathrm{psi}
$$

The stresses in the weld are below the allowable levels (see Table 2). The skid lifting loops, therefore, meet the requirements of the regulations.

Should the skid lifting loop fail due to excessive load, the failure will be by bending; containment, however, would not be lost and the ability of the package to meet the other requirements would not be impaired. 


\subsection{Top Plug Lifting Derice}

If there is a system of lifting devices that is a structural pan of the lid (top plug) only. the regulations require that this system shall be capable of supporting three times the weight of the lid (top plug) and any attachment without generating stress in any material of :he lid in excess of its gield strength. It is further required that. unkess rendered useless for lifting during transpon of the package. the lid lifting or other system of lifting devices shall conform to the requirements for the package-liftng system.

The cask has one lid (top plug) lifting lug (see Fig. 8). and hoth the body cf the top plug and the lifting lug are fabricated from 304L stainkss steel. The lifting lug is located at the geonetric center of the top plus.

The following analysis is based on equations given by Roark ${ }^{\top}$ which an be used to predict stress concentration factors found in the atralysis of curved beams. For a value of $R c=0.8750 .3125=2.80$. where $R$ is the radius of curvature measured to the centroid of the section and $c$ is defined below, a table supplied by Roart shows the following:

and

$$
k_{1}=1.34=S_{i}: S
$$

$$
k_{n}=0.79=S_{\circ} S \text {. }
$$

where

$k=$ the st:ess concentration factor,

$S_{1}=$ actual stress in extreme fiber on soncave side.

$S_{n}=$ actual stress in extreme fiber on convex side,

$S=$ unit stress in corresponding fiber as computed by ordinary fexure formula for a straight beam.

$$
\mathbf{S}=\mathbf{M c} \mathbf{I}
$$

where

$$
\begin{aligned}
& M=\text { bending moment, } F 、 l / 8 \text {, in.-lb, } \\
& c=\text { distance from centroidal axis to extreme fiber, } 0.3125 \text { in.. } \\
& I=\text { moment of inertia, } 8: 12 \mathrm{tc}^{3} \text {. } \\
& L=\text { length of beam, } 1.375 \text { in., } \\
& F_{v}=\text { force, 3W. }
\end{aligned}
$$


OANL DWg 60.11733A2

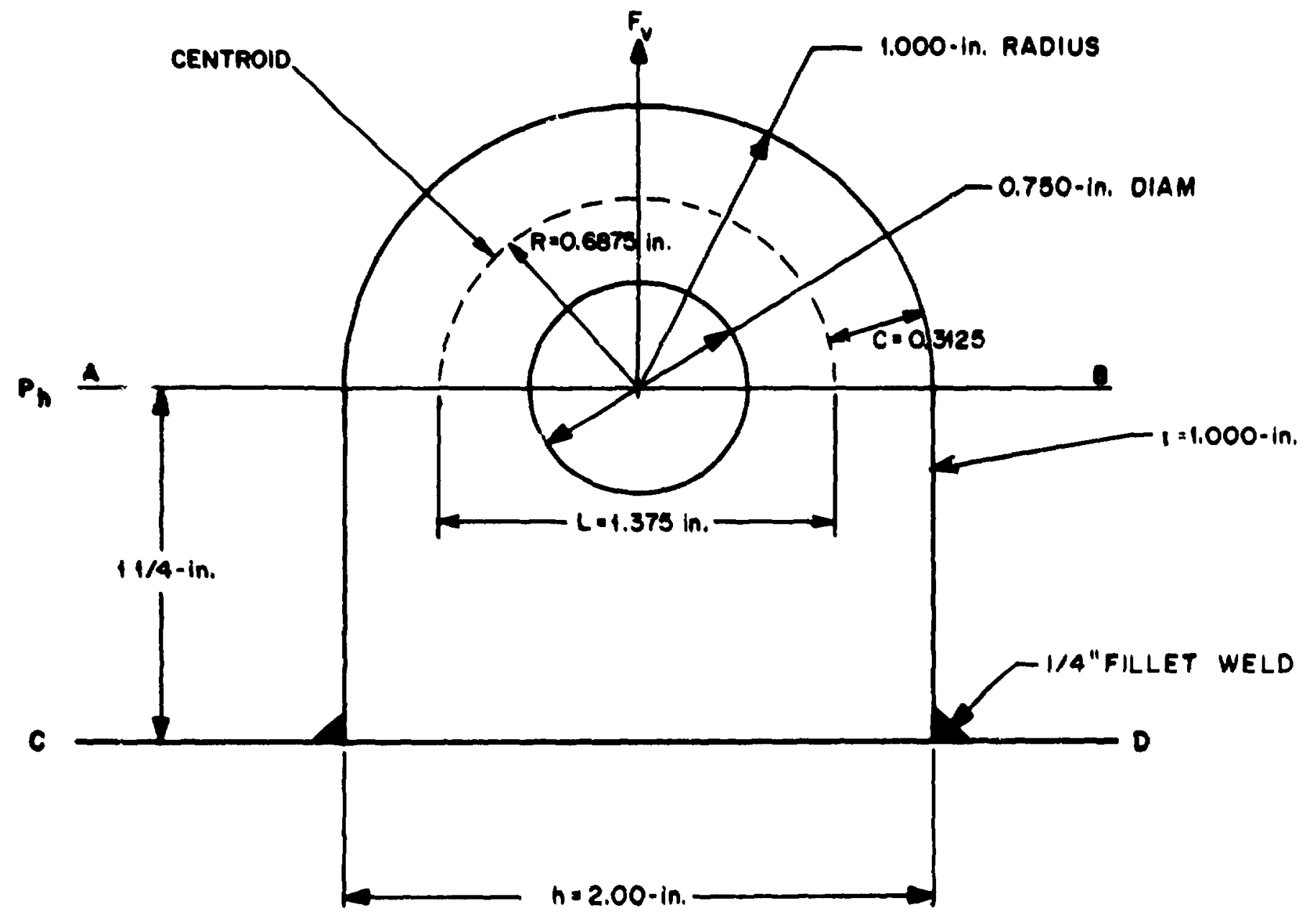

F18. 8. Top plug lifting lug. 


$$
\begin{aligned}
& \underline{\underline{w}}=\mathbf{H} \text { eight of top plug. } 1170 \mathrm{lb} . \\
& r=\text { radius of beam. } 0.75 \mathrm{in} .
\end{aligned}
$$

Substituting these values and the dimensions showi in Fig. 8.

$$
\begin{aligned}
& F=3(1170)=3510 \mathrm{lb} . \\
& \mathbf{M}=(3510 \times 1.375) \mathrm{g}=603 \mathrm{in} .-\mathrm{lb} . \\
& I=23(1.0 \times 0.3125)^{3}=0.0203 \mathrm{in} . \\
& S=(603 \times 0.3125) 0.0203=9300 \text { psi. }
\end{aligned}
$$

Therefore.

and

$$
S_{i}=k S=(1.34 \times 9300)=12.500 \text { psi. }
$$

$$
S_{\diamond}=k . S=(0.79)(9300)=7350 \text { psi. }
$$

Thus the stresses in the extreme concave fiber and in the extreme convex fiber of the top plug lifting lug are less than the tensile yield strength of the stainless steel material (see Table 2).

The tension in the weld is determined by the following:

$$
\sigma_{w}=F_{v} L(s)=3510,6.00(0.25)=2340 \text { psi, }
$$

where

$$
\begin{aligned}
& L=\text { length of weld. } 6.00 \mathrm{in.} . \\
& s=\text { size of weld. } 0.25 \mathrm{in} .
\end{aligned}
$$

The shear in the weld is found by the equation:

$$
\tau_{w}=F_{v} L_{s}=3510,600(0.25)=2340 \text { psi. }
$$

The maximum shear in the weld is determined by the equation:

$$
\sigma_{\text {max }}=\left(\sigma_{m} / 2\right) \pm\left[\left(\sigma_{m} / 2\right)^{2}+\left(\tau_{-}\right)^{2}\right]^{1 \cdot 2}=2340 / 2 \pm\left[(2340 / 2)^{2}+(2340)^{2}\right]^{12}=3790 \text { psia }
$$

The stresses in the weld are below the allowable limits (see Table 2); therefore, the top plug lifting lug meets the requirements of the regulations.

Should the top plug lifting lug fail due to excessive load, the failure will be by bending; containment, however, would not be lost. and the ability of the package to meet the other requirements would not be impaired. 


\subsection{Tie-Down Device}

The reguhtions require that if there is a system of tie-down devices which is a structural part of the package, this system must be capable of withstanding a static force applied to the ceater of gravity of the packaze with (1) a vertical componeet of two tines the weight (2Yi) of the pectage and its contents. (2) a borizontal component along the direction of travel of ten times the weight (10 $\mathrm{Y}$ ) of the package and its contents, and (3) a horizonta! component in the transerse direction of five times the weight (SWI) of the pactage and its contents. This applied load shall not generate stresses in any materiai of the package in excess of the yietd streagth of that material. In addition, any tic-down device that is a struturel part of the pactage must be desizned so that failure of the device under excessive load will not impair the ability of the package to meet ofber requirements of the regulations.

The Garden Carrier No. 2 is normally shipped bolted to its stid and enclosed in its fire shicld as shown in Fig. 2. The overall plan for tying the package to the vehicke is shown in Fis 9. Eight wire ropes tie the package to the vehick: (1) four (Nos. 1, 2. 3, and 4) run from the stid tie-down loops to the vehick, and (2) four (Nos. 5, 6. 7, and 8) run from the fire shiedd tie-down lugs to the velicke.

To demonstrate the adequacy of the tie-downs, it will be demonstrated that: (I) the tie-down of the Garden Carrier to the skid is adequate, (2) the tie-down of the fire shield to the skid is adequate, and (3) the stresses imposed on the fire shield tiedown lug and its attachment to the fire shield are acceptable.

\subsection{Thedown of Garden Carrier No. 2 10 skid}

The Garden Carrier No. 2 is secured to its skid by means of eight 1-1 4-in.-diam bolts that have a specified material yield stress of 150,000 psi and are located as shown in Fig. 10.

To analyze this part of the tie-down system, the cask was considered as a cantilevered beam. At the plane of attachment, the cross section of the beam consists of the bolts loaded in tension and a strip, a. loaded in compression, as shown in Fig. 11. It is obvious that the maxisium stress occurs at this plane. Since the genmetry is circular, it is a computational adventage to combine the $S$ and $10-W$ loads vectorially:

$$
P=\left[(5 W)^{2}+(10 Y)^{2}\right]^{12}=11.18 Y .
$$

The line of action of $P$ has been taken as the $X$ axis, which is sotated from the direction of trevel by an angle, $a$, as shown in Fig. 10, and is calculated below:

$$
a=\tan ^{-1} 5 / 10=26.56^{\circ} .
$$


ORNL DWG 75-4892
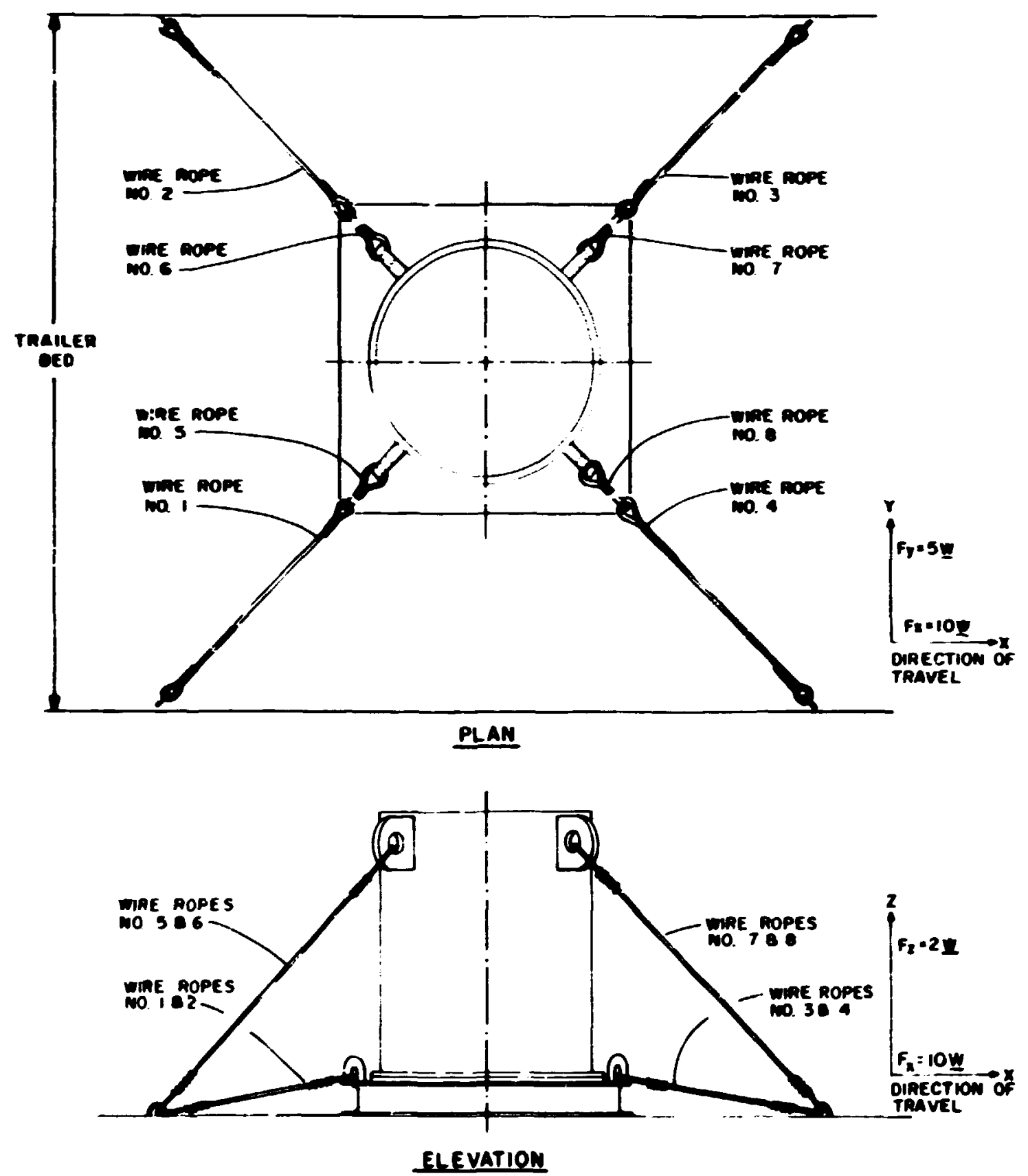

818. 9. Tie-down plan of the Garden Carrier No. 2 to the vehicle. 


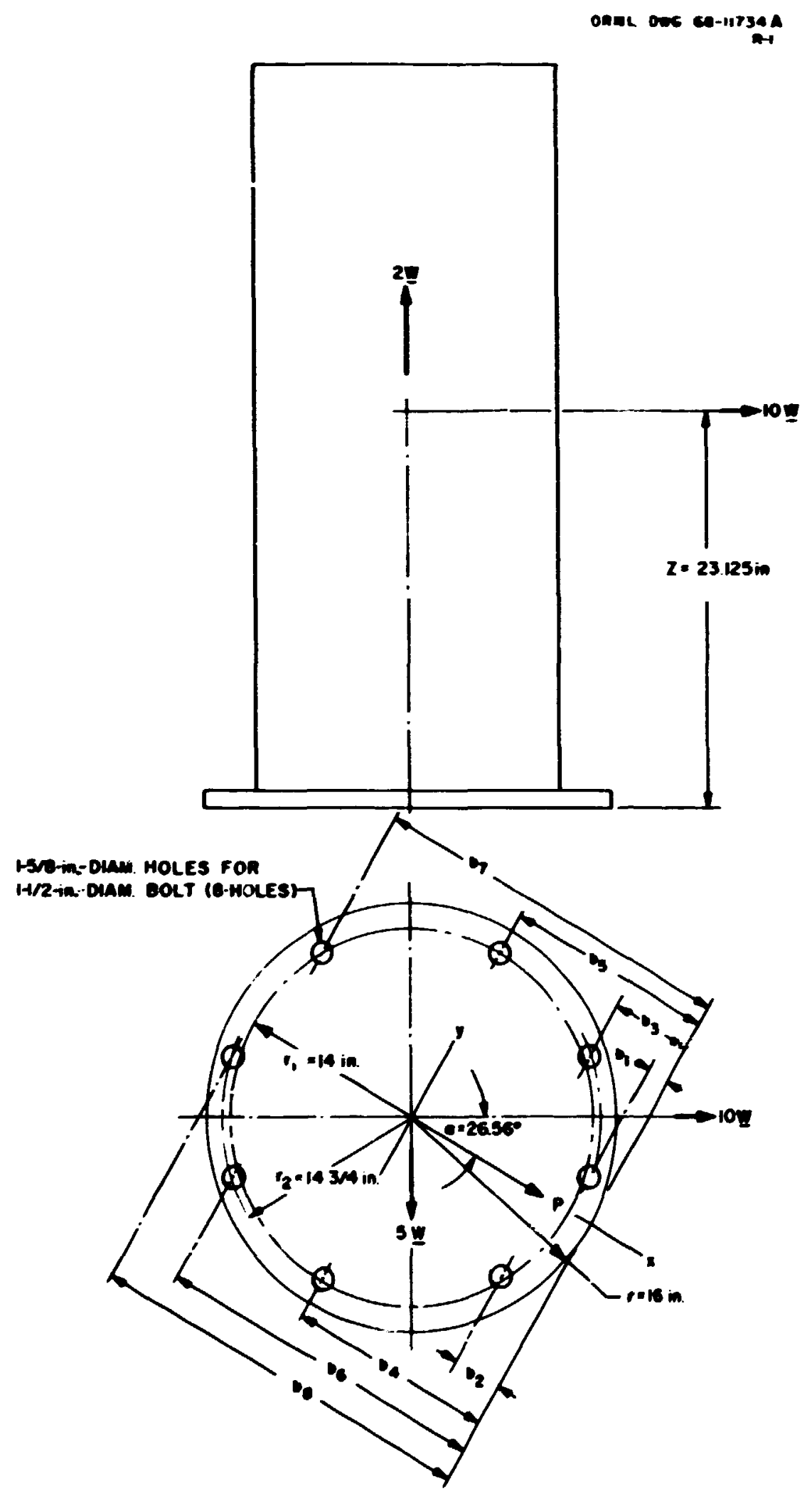

F1g. 10. Bolting pattern and computational model for analysis of the tie-down system of the Garden Carrier No. 2 to its skid. 


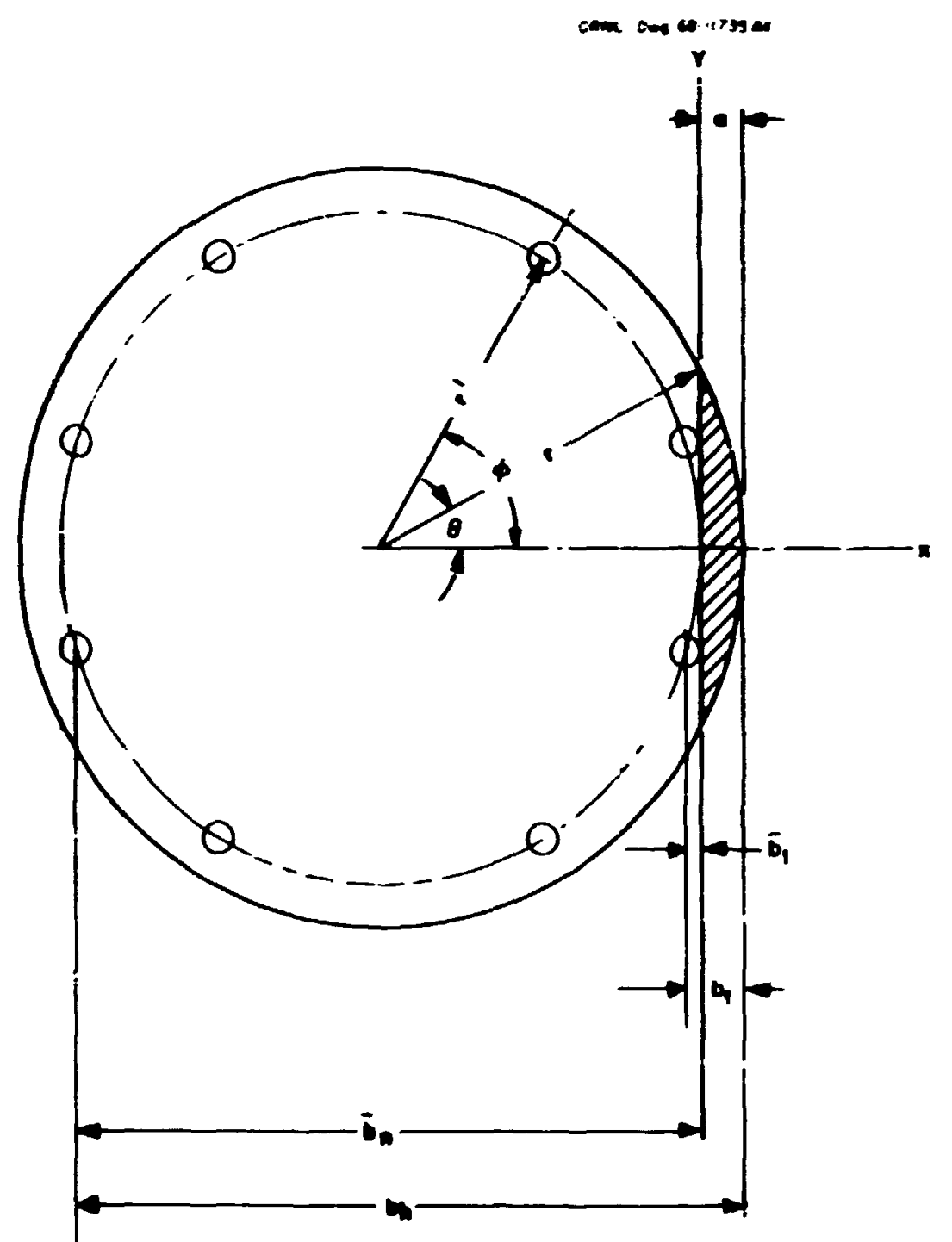

plan at the attachment plane

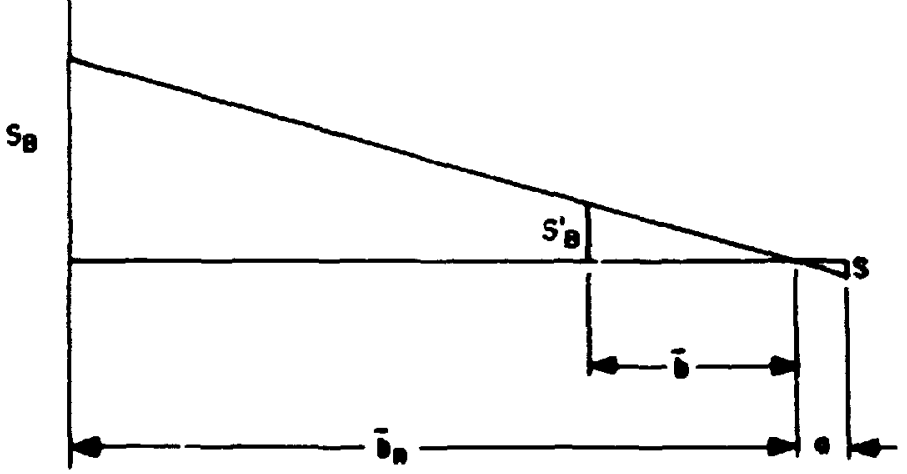

STRESS DIAGRAM

P18. 11. Plan at actachment plane and stress diagram for the tie-down system when the cask or the fire shleld is considered as a cantilevered beam. 
The neutral axis, shown as the $Y$ axis in Fios. 10 and II. must first be bocted. Using methods of amblysis previoushy deveioped."

$$
\Sigma b=\left(r^{3}: A\right)_{\eta}+\mathbf{r N} \boldsymbol{\beta} .
$$

Dhere

$$
\begin{aligned}
& A=\text { cross-sectional area of a butt, 1.005 sq in., } \\
& \eta=+\sin ^{3} \theta / 3-\theta \cos \theta / 2+\sin 20 \cos \theta / 4, \\
& \beta=(i-\cos \theta) \text {. } \\
& b=r-r^{2}+(I-\cos \varphi)(\sec T \text { Table 4). } \\
& \mathbf{N}=\text { number of effective bohs, } 7 . \\
& r=\text { radius base phate, } 16 \text { in., } \\
& r=\text { centerline radius of bolt, in. }
\end{aligned}
$$

Therefore,

$$
\Sigma b=125.96 .
$$

The value of $\theta$ was calculated to be $44.5^{\circ}$ : the neutral axis located at a distance. a. from the edge of the baseplate and is calculated in the following manner:

$$
a=(1-\cos \theta)=16\left(1-\cos 44.5^{\circ}\right)=4.59 \mathrm{in} .
$$

The moment of inertia of the section is computed by the following equation:"

$$
\begin{aligned}
I= & 2 r\left[\theta / 8-\sin 4 \theta / 32-2 \cos \theta \sin ^{3} \theta / 3+\cos ^{2} \theta(\theta / 2-\sin 2 \theta / 4)\right]+A_{\Sigma} b^{2} \\
= & 2(16)^{4}\left[0.777 / 8-0.03448 / 32-2\left(0.7(32)(0.7010)^{3} / 3+(0.7132)^{2}\right.\right. \\
& (0.777 / 2-.9998 / 4)]+1.405(1766.89)=2841 \text { in } 4
\end{aligned}
$$

The bending stress in the most distant bolt from the neutral axis is expressed by the following equation: 
Table 4. Values of $b, \bar{b}$, and $\bar{b} \bar{c}$ for cask tie-down

\begin{tabular}{|c|c|c|c|c|}
\hline Distance of bolt center from & edge of baseplate ${ }^{a}$ & $\mathbf{b}^{\mathbf{a}}$ & $\bar{b}^{-\mathbf{b}}$ & $\bar{b}^{2}$ \\
\hline$b_{1}=16-14(\cos 3.44)$ & $=$ & 2.03 & 一 & - \\
\hline$b_{2}=16-14.75(\cos 45.67)$ & $=$ & 5.69 & 1.10 & 1.21 \\
\hline$b_{3}=16-14(\cos 56.56)$ & $=$ & 8.28 & 3.69 & 13.62 \\
\hline$b_{4}=16-14.75(\cos 81.21)$ & $=$ & 13.74 & 9.15 & 83.72 \\
\hline$b_{5}=16+14.75(\sin 8.79)$ & $=$ & 18.26 & 13.67 & 186.87 \\
\hline$b_{E}=16+14(\sin 33.44)$ & $=$ & 23.71 & 19.12 & 365.57 \\
\hline$b_{7}=16+14.75(\sin 44.33)$ & $=$ & 26.31 & 21.72 & 471.76 \\
\hline$b_{8}=16+14(\sin 86.56)$ & $=$ & 29.97 & 25.38 & 644.14 \\
\hline
\end{tabular}




$$
\begin{aligned}
S_{\boldsymbol{e}} & =\mathbf{P Z b _ { n }} I \\
& =11.18(8610 \times(23.125 \times 25.38): 241 \\
& =19.900 \mathrm{pai}
\end{aligned}
$$

The direct tensile stres distribured equally in all bolts is calculated by the followiag equation:

$$
S_{\mathrm{r}}=2 \mathrm{~W} / \mathrm{N}_{\mathrm{r} . \mathrm{I}}=2(8610) / 8(1.405)=1530 \mathrm{psi} \text {. }
$$

where

$$
N_{T}=\text { total number of bohs, } 8 .
$$

The shearing stress distributed equally in all bolts, neglecting friction, becomes the following:

$$
S_{s}=P N_{r A}=11.18(8610)(8(1.405)=8560 \text { psi. }
$$

From Mohr's circle of stress. the maximum stress in the most siressed bolt will be expressed as follows:

$$
\begin{aligned}
S_{\text {max }} & =S_{z}+S_{r} \cdot\left\{\left(S_{z}+S_{r} 2\right)^{2}+S_{s}^{2}\right]^{12} \\
& =19.900+1530 ; 2+\left[\left(19.900+1530(2)^{2}+(8560)^{2}\right]^{\prime 2}\right. \\
& =24.430 \text { psi. }
\end{aligned}
$$

It is therefore concluded that the tie-down system of bolts of the Garden Carrier No. 2 to the skid exceeds the requirements of the regulations since the computed maximum stress is less than the yield stress (150,000 psi) of the bolting material specified on the drawing and also less than (30,000 psi) yield stress for mild steel; therefore, any socket-head bolt of the correct dimensions may be used for this purpose. Since the stress on the most stressed bolt is also below the yield strength for the 1-in.-thick $304 \mathrm{~L}$ base plate, it will satisfy the requirements.

If any portion of the tie-down system of the Garden Carrier No. 2 to the skid should fail d!"- to excessive load, containment would not be lost, and the ability of the package to meet the requirements would not be impaired.

\subsubsection{Tie-down of fire shield to skid}

The fire shield is secured to the skid with eight bolts of the same size and type as are used for the tie-down of the cask to the skid (see Sect. 3.5.1). The bolis are located on a 22-3/4-in.-radius bolt circle, as shown in Fig. 12. 
CRNL OWG $\begin{array}{r}75-4893 \\ A-1\end{array}$
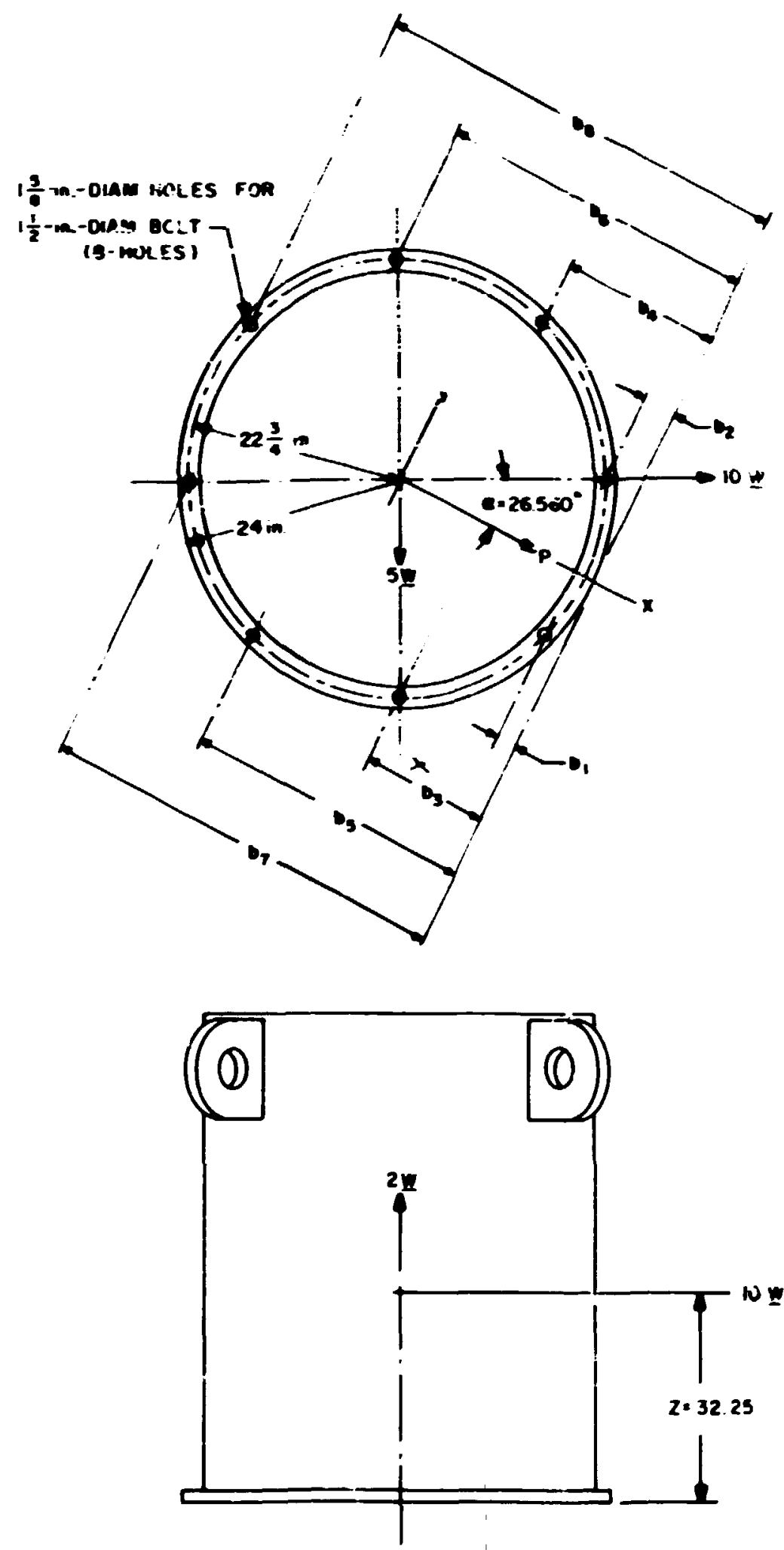

Fig. 12. Bolting pattern and computational model for analysis of the tie-down system of the fire shield to the skid. 
To analyze this part of the tie-down system, the fire shield was considered as a cantilevered beam. At the plane of attachment, the cross section of the beam consists of the bolts loaded is tension and a strip. 2, loaded in compression. as shuin in Fig. 1I. It is obvious that the maximum stress occurs at this plane. Since the geometry is circular, it is a computational advantage to combine the 5-and 10-W loads vectorially:

$$
\left.P=\left[(5 W)^{2}+(10 W)^{2}\right]\right]^{12}=11.18 Y \text {. }
$$

The line of action of $P$ has been taken as the $X$ axis, which is rntated from the direction of travel by an angle, $a$, as shown in Fig. 12.

$$
a=\tan ^{-1} 5 / 10=26.56^{\circ} \text {. }
$$

The neutral axis, shown as the $Y$ axis in Figs. 11 and 12 must first be located. Using methods of analysis previously developed,

where

$$
\mathbf{s} b=2 \mathbf{r}^{3} / \mathbf{A} \boldsymbol{\eta}+\mathbf{r N} \boldsymbol{B},
$$

$$
\begin{aligned}
& A=\text { cross-sectional area of a bolt, } 1.405 \text { sq in., } \\
& \eta=\left(+\sin ^{3} \theta / 3-\theta \cos \theta / 2+\sin 2 \theta \cos \theta / 4\right), \\
& \beta=(1-\cos \theta), \\
& b=r-r^{\prime}(1-\cos \varphi)(\text { see Table } 5), \\
& N=\text { rumber of effective bolts, } 7, \\
& r=\text { radius base plaic, } 24 \text { in., } \\
& r^{\prime}=\text { centerline radius of bolt, } 22.75 \text { in. }
\end{aligned}
$$

Therefore,

$$
\Sigma \mathbf{b}=192.0 .
$$

The value of $\theta$ was calculated to be $38.3^{\circ}$, and the natural axis is located at a distance. a. from the edge of the plate where

$$
a=r(1-\cos \theta)=24\left(1-\cos 38.3^{\circ}\right)=5.16 \text { in }
$$

The moment of inertia of the section is calculated by the following:" 
Table 5. Values of $b, \bar{b}$, and $\bar{b}^{2}$ for fire shield tie-down

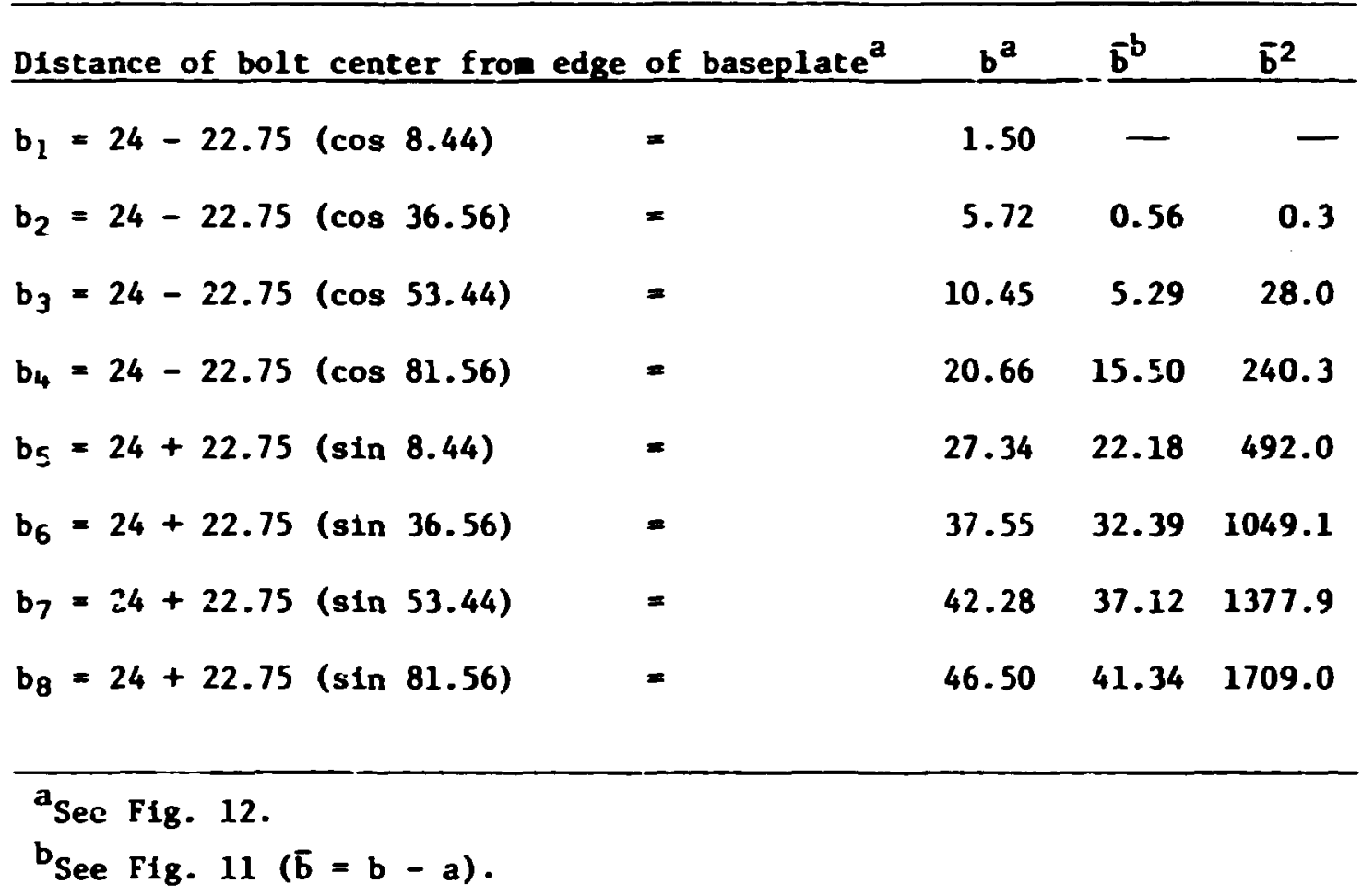




$$
\begin{aligned}
I & =2 r^{4}\left[\theta / 8-\sin 4 \theta / 32-2 \cos \theta \sin ^{3} \theta / 3+\cos ^{2} \theta(\theta / 2-\sin 2 \theta / 4)\right] \\
& +A \Sigma \bar{b}^{2} \\
& =2(24)^{4}\left[0.669 / 8-0.4506 / 32-2(0.7848)(0.6199)^{3} / 3\right. \\
& \left.+(0.7848)^{2}(0.669 / 2-0.9728 / 4)\right]+1.405(4896.5)=7638 \text { in. } \therefore
\end{aligned}
$$

The bending stress in the most distant bolt from the neutral axt. is expressed as follows:

$$
\begin{aligned}
\mathbf{S}_{\iota} & =\mathbf{P Z b _ { w } / I} \\
& =11.18(2600)(32.25 \times(41.34) / 7638 \\
& =5074 \mathrm{psi} .
\end{aligned}
$$

The direct tensike stress distributed equally in all bolts is expressed by the following:

$$
S_{T}=2 \underline{W} / N_{T A}=2(2600) / 8(1.405)=463 \mathrm{psi} \text {. }
$$

where

$$
N_{T}=\text { total number of bolts, } 8 \text {. }
$$

The shearing stess distributed equally in all bolts, neglecting friction, becomes

$$
S_{s}=P / N_{T A}=11.18(2600) / 8(1.405)=2586 \mathrm{psi}
$$

From Mohr's circle of stress, the maximum stress in the most stressed bolt becomes

$$
\begin{aligned}
S_{\text {max }} & =S_{\Perp}+S_{r} / 2\left[\left(S_{\Perp}+S_{r} / 2\right)^{2}+S_{s}^{2}\right]^{J / 2} \\
& =5074+463 / 2+\left[(5074+463 / 2)^{2}+(2586)^{2}\right]^{1 / 2} \\
& =6557 \mathrm{psi} .
\end{aligned}
$$

It is therefore concluded that the tie-down system of bolts of the fire shield to the skid exceeds the requirements of the regulations because the computed maximum stress is less than the yield stress $(150,000$ psi) of the bolting material specified on the drawing and also less than the yield stress $(30,000$ psi) for mild steel; thus any socket-head bolt of the correct dimensions may be used for this purpose. Since the stress on the most stressed bolt is also below the yield strength for the l-in.-thick $304 \mathrm{~L}$ base plate, it will satisfy the requirements.

If any portion of the tie-down system of the fire shield to the skid should fail due to excessive load, containment would not be lost, and th: ability of these packages to meet the requirements would not be impaired. 


\subsubsection{Tie-down of fire shield to vehicle}

The wire rope (tension member) pulls directly on the tie-down lug (see Fig. 9). A $45^{\circ}$ loading of the tie-down lug was chosen as a convenient angle (being in line with the lug). The force imposed on the tie-down lug is broken down into its componerits (vertionl, $F_{z:}$ forward. $F_{r}$ and transverse, F, loads). These loads are added and compared to the stress in the metal and the strength of the weld holding the tie-down lug to the fire shield. No credit is taken for the tiedown from the skid to the vehick.

Vertical load application. The forces on the tie-down $\left(F_{s}\right)$ resulting from the application of a vertical load applied to the center of gravity of two times the weight of the package are found by a summation of the vertical forces (see Fig. 13):

$$
\begin{aligned}
& \Sigma F_{v}=0 .+=! \\
& \Sigma F_{v}=0=2 \underline{W}-\underline{W}-4 F_{z} \\
& F_{z}=\mathbf{W} 4=12,4004=3100 \mathrm{lb},
\end{aligned}
$$

where

$$
\underline{W}=\text { cask plus contents and skid weight (see Table I): } 12.400 \mathrm{lb} \text {. }
$$

The tension in the tension member from the $2 \underline{W}$ load is

$$
T_{z}=F_{z}\left(\sin 45^{\circ}\right)=3100(0.707)=4380 \mathrm{lb}
$$

Fornard load application. The forces on the tie-down $\left(F_{z}\right)$ resulting from the application of a horizontal force applied to the center of gravity in the direction of travel of ten times the weight of the package are found by summing the horizontal forces (see Fig. I4):

$$
\begin{aligned}
& \mathbf{L F}=0,+=- \\
& \sum F_{M}=0=10 \underline{W}-2 F_{x} \\
& F_{x}=10 \mathbb{Z} 2=10(12,400) 2=62,000 \mathrm{lb} \text {. }
\end{aligned}
$$

The tension in the tension rnember from the low load is

$$
T_{1}=F_{x} /\left(\cos 45^{\circ}\right)\left(\cos 45^{\circ}\right)=62,000 /(0.707)(0.707)=124,040 \mathrm{lb} .
$$


ORNL DWG $\begin{array}{r}75-4890 \\ R-1\end{array}$

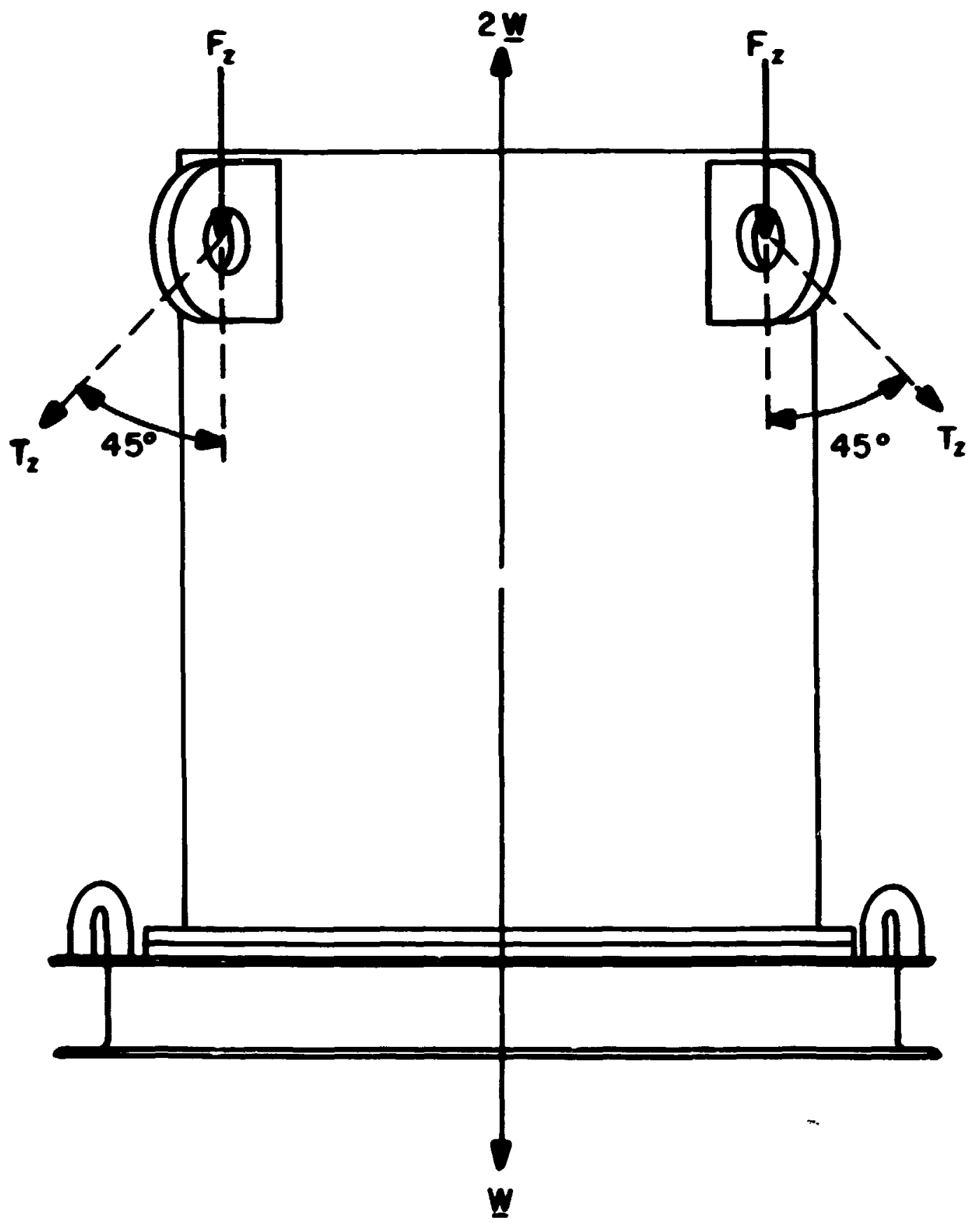

F18. 13. Forces due to vertical thrust on Garden Carrier No. 2. 
ORNL DWG. 75-4889 R-I

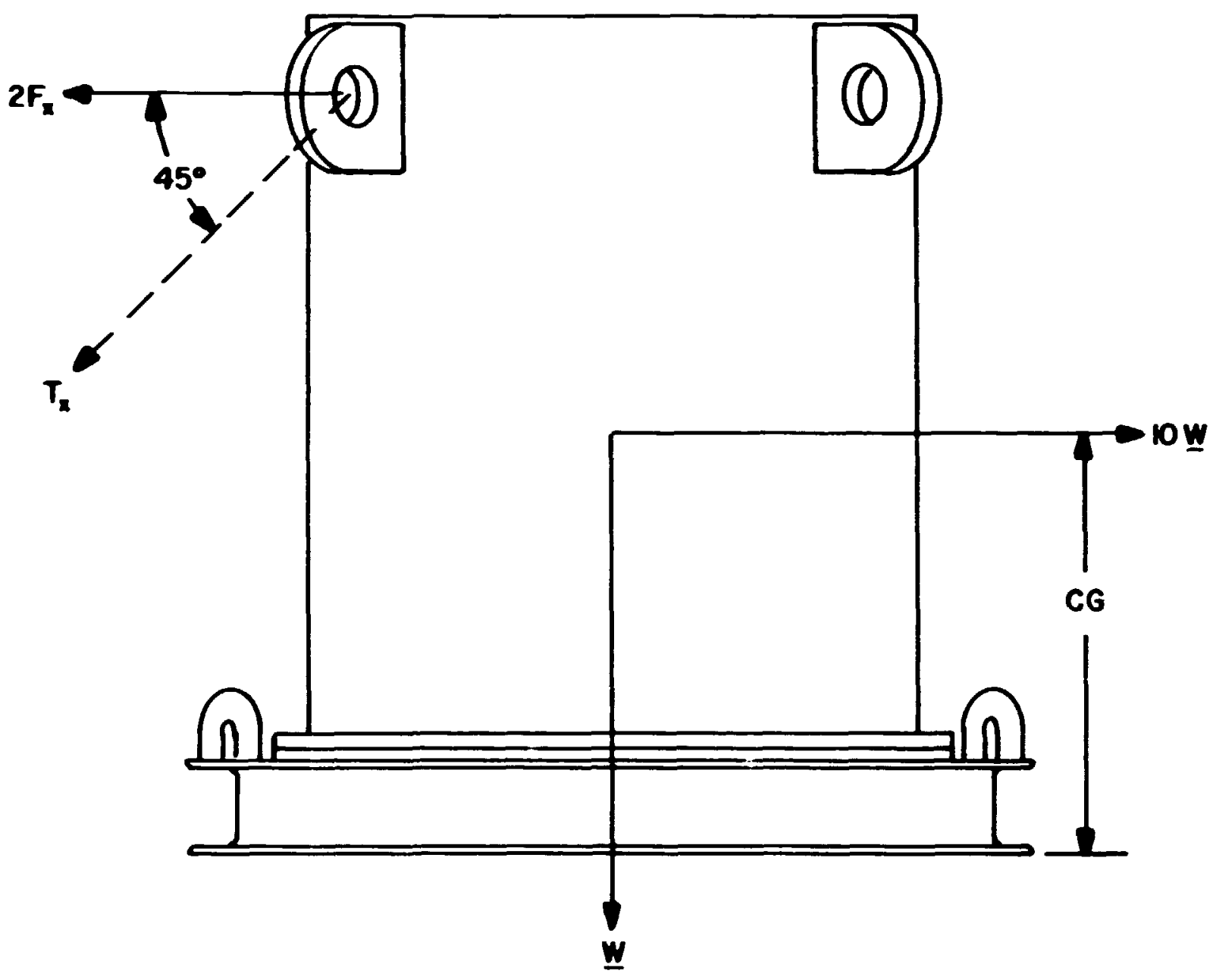

Fig. 14. Forces due to the forward thrust on Garden Carrier No. 2. 
Trenswerse load application. The forces on the tie-down $\left(F_{2}\right)$ resuling from the application of a borizontal force applied to the center of gravity transverse to the direction of travel of five times the weight of the package are found by a summation of the forces in the transverse direction (see Fis 15):

$$
\begin{aligned}
& \Sigma F_{T}=0,+= \\
& \Sigma F_{n}=0=5 \mathbb{W}-2 F_{y} \\
& F_{y}=5 W / 2=5(12,000) / 2=31,000 \mathrm{lb} .
\end{aligned}
$$

The tension in the tension member from the SW transverse load is

$$
T_{,}=F_{y} !\left(\cos 45^{\circ}\right)\left(\sin 45^{\circ}\right)=31,000 /(0.707)(0.707)=62.020 \mathrm{mb} .
$$

Combined load application. The force produced for the forward $\left(T_{s}\right)$, transverse $(T$,$) , and$ vertical $\left(T_{z}\right)$ applied loads may be added to determine the total tension in the tension member.

$$
T_{T}=T_{x}+T_{y}+T_{x}=124,040+62,020+4,380=190,440 \mathrm{Bb} .
$$

The horizontal and vertical components of the combined force (see Fig. 16) on the tie-down lug is found in the following manner:

For the horizontal,

$$
F_{C M}=T_{r} \sin 45^{\circ}=190,400(0.707)=134,600 \mathrm{lb}
$$

For the vertical,

$$
F_{C r}=T_{T} \cos 45^{\circ}=190,440(0.707)=134,600 \mathrm{lb} .
$$

The tensike streas in the tie-down lug along plane A-A (see Fig. 16) is calculated as follows:

$$
\text { o }=F_{C M} / h t=134,600 / 12.5(2.25)=4,790 \mathrm{psi} \text {, }
$$

where

$$
\begin{aligned}
& h=\text { depth of lifting lug, } 12.5 \mathrm{in} . \\
& \mathrm{t}=\text { thicknews of lifting lug, } 2.25 \mathrm{in} .
\end{aligned}
$$


ORNL DWG. 75-489I

R-I

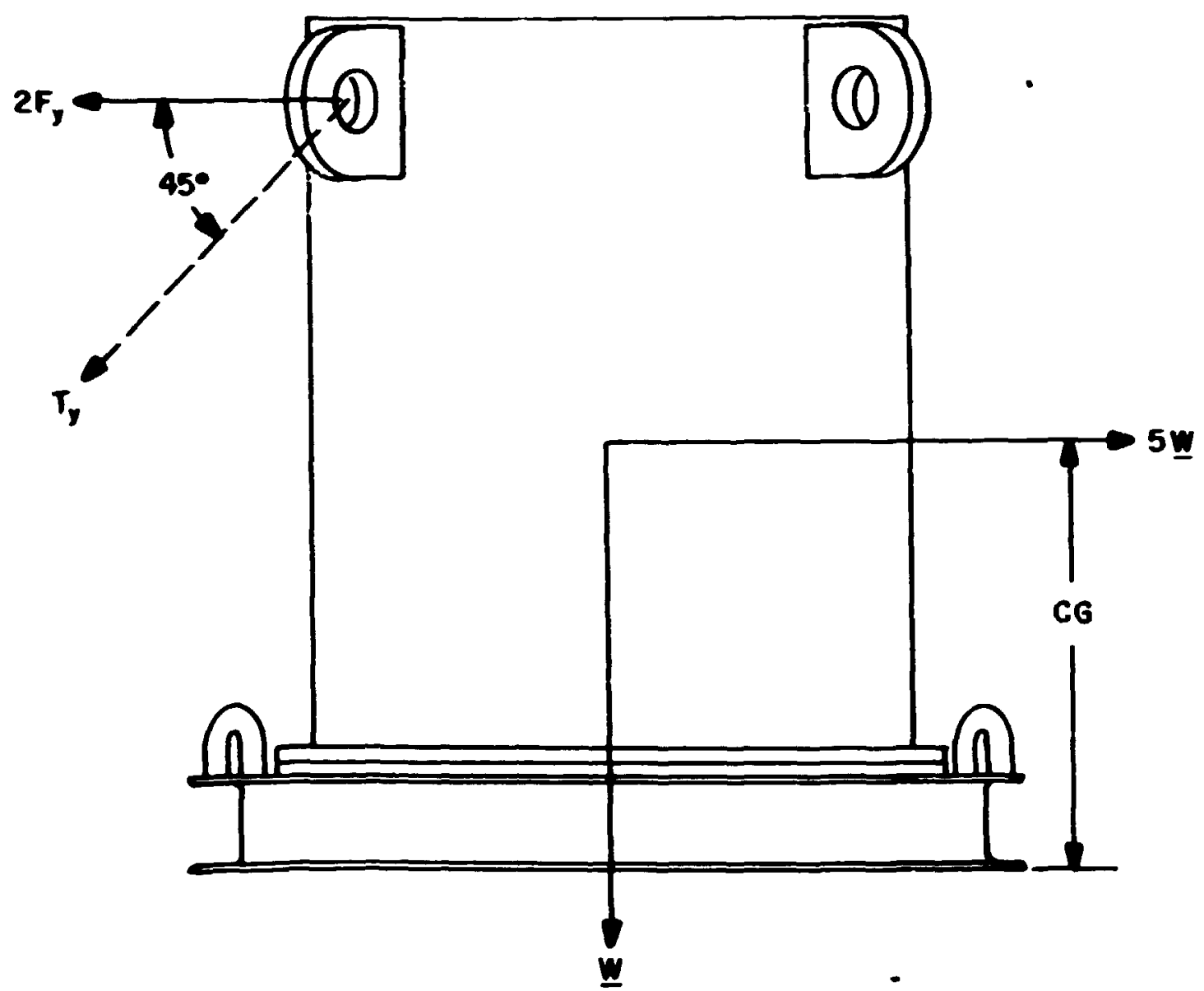

Fig. 15. Forces due to the transverse thrust on Garden Carrier No. 2. 


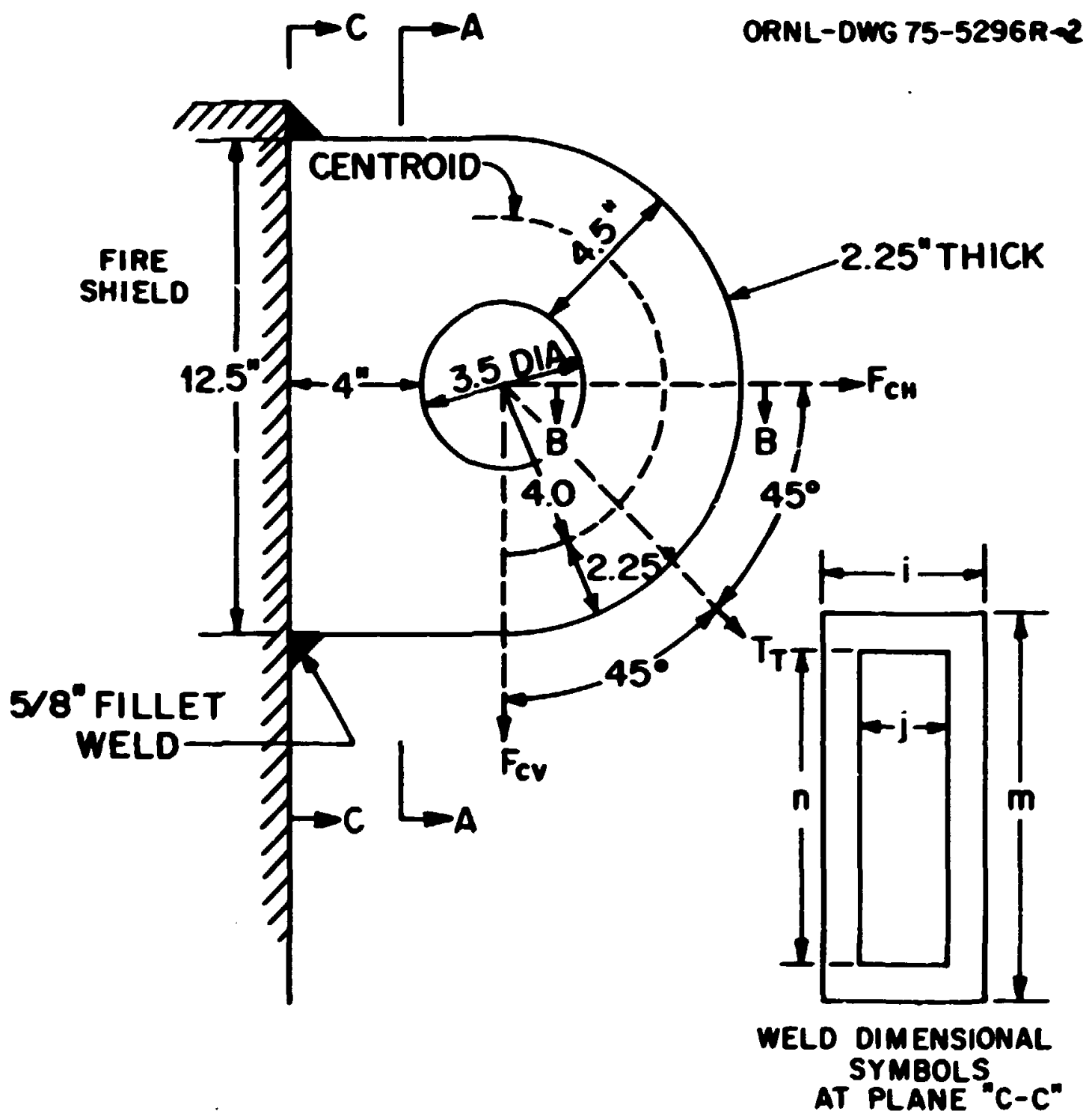

Fig. 16. Fire shield lifting lug used as a tie-down. 
The shear stress in the tie-down lug along plane A-A (see Fig. 16) is calculated as follows:

$$
r=F_{C r} h T=134,600 .(12.5 \times(2.25)=4.790 \mathrm{psi}
$$

The bending stress on the tie-down lug along plane A-A (see Fig. 16) is calculated as follows:

$$
\sigma \beta=M C I=774,000(6.2) \cdot 366=13,200 \text { psi, }
$$

where

$$
\begin{aligned}
& \mathbf{M}=\mathbf{F}_{\mathrm{cm}, \text { in }}+\mathbf{b} \text {. } \\
& \mathrm{a}=\text { distance edge to center of hole, } 5.75 \mathrm{in} . \\
& h=\text { depth of section, } 12.5 \text { in. } \\
& \text { ! = thickness of section. } 2.2 \text { in., } \\
& C=\text { centroid distance from edge, } h 2=12.52=6.25 \text { in., } \\
& I=112 \text { th. }^{3} \text { in. } \\
& M=134.600(5.75)=774,000 \text { in. } \\
& I=2.2512(12.5)^{3}=366 \mathrm{in}^{4} .
\end{aligned}
$$

The bending stress in the curved beam is based on equations given by Roark' which can be used to predict stress concentration factors found in the analysis of curved beams. For a value of $r c=4.002 .25=1.8$. where $r$ is the radius of curvature measured to the centroid of the section and $c$ is defined below, a table supplied by Roark gives the following equations:

$$
k_{1}=1.63=S_{1} \cdot S
$$

and

$$
k_{\bullet}=0.70=S_{\bullet} / S \text {, }
$$

where

$$
\begin{aligned}
& k=\text { the stress concentration factor, } \\
& S_{1}=\text { actual stress in extreme fiber on concave side. }
\end{aligned}
$$


S. = actuel stress in exireme fiber on convex side.

$S=$ unit stress in corresponding fiber as computed by ordinary flexure formula for a straight beam.

$$
\mathbf{S}=\mathbf{M C}_{i} \boldsymbol{I},
$$

where

$M=$ maximum bending moment for beam with restrained ends, $F_{c k l}, 8$, in.-lb.

$C=$ distance from centroidal axis to extreme fiber, 2.25 in.,

$I=$ moment of ineria, $b d^{3} / 12$, in.:

$L=$ length of beam. $8.0 \mathrm{in}$.,

d = depth of beam, 4.5 in.,

$b=$ width of beam, 2.25 in.

Substituting these values and the dimensions shown in Fig. 16 ,

$$
\begin{aligned}
& M=(134,600)(8.0) / 8.0=134.600 \text { in. }- \text { lb. } \\
& I=2.25(4.5)^{3} / 12=17.09 \mathrm{in} . \\
& S=(134,600)(2.25) / 17.09=17.720 \mathrm{psi} .
\end{aligned}
$$

Therefore, the stress on the extreme fibers along the plane Fcv (see Fig. 16) is found from the following equation:

$$
S_{i}=k_{s} S=(1.63)(17,720)=28,890 \mathrm{psi} \text {, }
$$

and

$$
S_{0}=k_{0} S=(0.70)(17,720)=12,400 \text { psi. }
$$

Thus the bending stresses in the extrer re concave fiber and in the extreme convex fiber are less than the tensile yield strength of the mild steel material (see Table 2). Hence the design meets the requirements. 
The tensile stress in the weld (along plane CC Fig. 16) is calculated as follows:

$$
o_{T}=F_{v u}(\mathrm{im}-\mathrm{jnj}=134,600 ;[(3.25) \times 13.5)-(2 \times 12.25)]=6950 \mathrm{psi}
$$

The shea: stress in the weld is determined as follows:

$$
\tau=F_{c r}(\mathrm{im}-\mathrm{jn})=134.600[(3.25)(13.5)-(2)(12.25)]=6950 \mathrm{psi} .
$$

The bending stress in the weld is calculated as follows:

$$
\sigma_{\bullet}= \pm M C l=302.850 \times 6.625360=5570 \mathrm{psi} .
$$

where

$$
\begin{aligned}
& M=F_{c r b}=(134.600 \times 2.25)=302.850 \text { in }-1 b \\
& C=m .2=13.252=6.625 \text { in. } \\
& I=\left(\mathrm{im}^{3}-\mathrm{jn}^{3}\right) 12=\left[(3.25)(13.5)^{3}-(2)(12.25)^{3}\right] 12=360 \mathrm{in.}^{4}
\end{aligned}
$$

The tie-down lugs are capable of resisting the tie-down loads and therefore meet the requirements of the regulations.

If the tie-down lug were to pull out of the fire shield or fail due to excessive loads. the failure would most likely be tension in the weld or bending of the tie-down lug: however. containment would not be lost, and the ability of the package to meet other requirements would not be impaired.

\section{STANDARDS FOR TYPE B AND LARGE QUANTITY PACKAGING}

The structural standards for large quantity packaging include load resistance of the packaging and the external pressure which the package must withstand. Compliance of the Garden Carrier No. 2 with these requirements is discussed in the following subsections.

\section{I Load Resistance}

When regarded as a simple beam supported at its ends along any major axis, the container must be capable of withstanding a static load normal to and uniformly distributed along its 
length that is equal to five times its fully loaded weigint: it should not generate stress in any material of the cask in excess of the yield strength of that material.

Both the cask and the fire shield will be analyzed.

\subsection{Load resistance of Garden Carrier No. 2}

The cross section of the cajix is composed of the ouret stainless steel shell, the lead shielding, and the inner stainkess stee! shell, as shown in Fig. 17. Since these zomponents are symmetrical about the same axis, the moment of inertia of the composite section is the sum of the equivalent moments of inertia of the individual components. For a thin stell, the moment of inertia, $I_{s}$, about its center is expressed by the following equation:

$$
I_{s}=\pi r_{m}^{3} t_{\text {. }}
$$

where

$$
\begin{aligned}
& I_{m}=\text { the mean radius of the thin shell, in., } \\
& t=\text { the thickness of the shell, in. }
\end{aligned}
$$

The moment of inertia of a hollow cylinder $\left(I_{m}\right)$, such as the lead shielding. becomes

$$
I_{n}=A\left(r_{0}^{2}+r_{i}^{2} / 4\right)
$$

where

$$
\begin{aligned}
& r_{0}=\text { outside radius, in., } \\
& r_{i}=\text { inside radius, in.. } \\
& A=\text { crosssectional area, } \pi\left(r_{0}^{2}-r_{i}^{2}\right), s q \text { in. }
\end{aligned}
$$

By the reinforced beam theory,

modulus of elasticity of steel/modulus of elasticity of lead $=n=30 \times 10^{6} / 2 \times 10^{6}=15$. (96) and

$$
\mathbf{n}=\text { actual area of lead/equivalent area of steel }=A_{\text {ro: }} A_{E S .}
$$


OANL D=9 68-11737m:
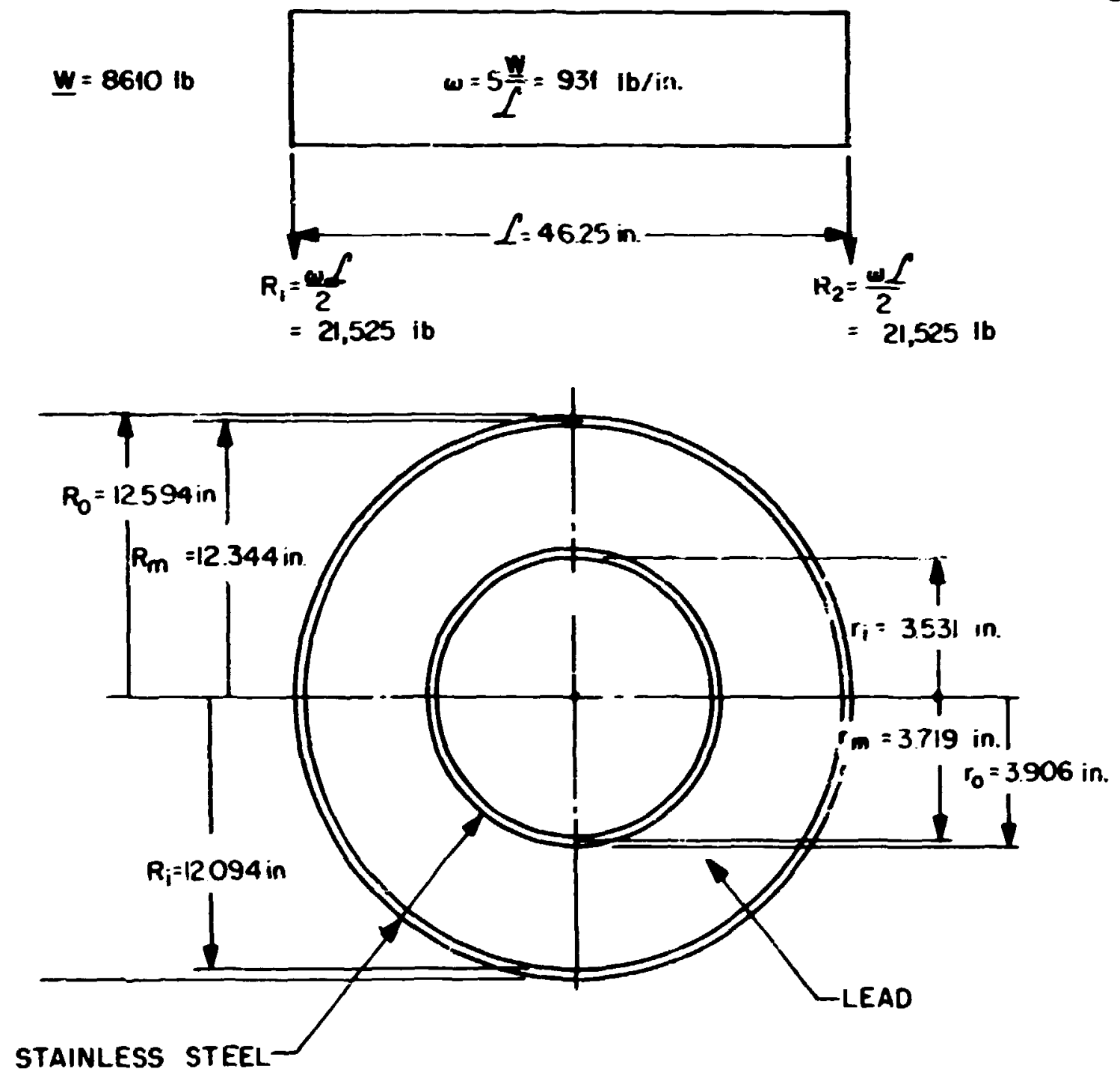

Fig. 17. The Garden Carrier No. 2 regarded as a simple beam and its equivalent cross section. 
where

$$
A_{E}=A_{n} / n=A_{n} / 15 .
$$

In order to convert the lead to equivalent steel. the following substitutions should be made in in Eq. (94):

$$
I_{m}=A_{n} 15\left(r_{0}^{2}+r_{i}^{2}: 4\right)=\pi_{i} 60\left(r_{0}^{4}-r_{i}^{4}\right)
$$

The moment of inertia of the section is determined by adding the three moments of inertia as follows:

$$
\begin{aligned}
I & =\pi \operatorname{Rm}^{3} t_{0}+\pi 60\left(r_{0}^{4}-r_{0}^{4}\right)+\pi r_{m}^{3} t_{1} \\
& =\pi(12.344)^{3}(0.5)+\pi / 60\left[(12.094)^{4}-(3.906)\right]+\pi(3.719)^{3}(.375) \\
& =4123 \mathrm{in} .
\end{aligned}
$$

where

$$
\begin{aligned}
& \left.r_{0}=R_{1} \text { (see } \bar{r} i g .17\right), \\
& r_{1}=r_{0} \text { (see Fig. 17). }
\end{aligned}
$$

The maximum bending moment occurs at $L / 2$ and can be determined from:

$$
M_{\text {max }}=R_{1} L / 2-\omega L^{2} / 8=21,525(46.25 / 2)-931(46.25)^{2} / 8=249,000 \text { in.-lb. }
$$

where

$$
\omega=\text { unit bending load in-lbs per lineal in. }
$$

The maximum stress is the bending stress at $1 . / 2$ and can be calculated in the following manner:

$$
S_{\text {s }}=M_{\text {mar }} R_{0} / I=249,000(12.594) ! 4123=761 \text { psi. }
$$

The Garden Carrier No. 2 exceeds the requirements of the standards for load resistance. 


\subsubsection{Load resistance of the fire shield}

The cross section of the fire shield area consists of two steel cylinders with insulation between them.as shown in Fig. 18. Since the insulation has no strength. only the outer shell will be considersd. For a thin shell, the moment of inertia. $I_{3}$. about its center is determined as follows:

$$
\begin{aligned}
& I=\pi \mathrm{R}_{m}^{3} \mathrm{t}_{0} \\
& I=\pi(21.25)^{3}(0.5) . \\
& I=15.070 \mathrm{in} .
\end{aligned}
$$

where

$$
\begin{aligned}
& R_{m}=\text { the mean radius (see Fig. 18), } 21.25 \text { in., } \\
& t_{0}=\text { the thickness of the outer shell, } 0.5 \text { in. }
\end{aligned}
$$

The maximum bending moment occurs at L. 2 and is calculated in the following manner:

$$
M_{\max }=R_{i} L, 2-\omega l^{2} 8=31.000(51.56) .2-1202(51.56)^{2} 8=399,750 \text { in. }-16 \text {. }
$$

The maximum stress is the bending stress at 1,2 and is expressed in the following equation:

$$
S_{\Perp}=M_{\max } R_{0} I=399,750(21.5) 15,070=570 \mathrm{psi}
$$

The fire shield therefore exceeds the requirements of the standards for load resistance.

\subsection{External Pressure}

The regulations require that the design of the shipping package be adequate to ensure that the containment vessel will suffer no loss of contents if subjected to an external pressure of 25 psig.

Each opening of the Garden Carrier No. 2 is gasketed. and experience has demonstrated that the gaskets used, as they are applied, are suitable to an external pressure of over 25 psig. Primary reliance for containment is on the inner container, see Sect. 8. It is demonstrated that the outer shell of the Garden Carrier No. 2 is capable of withstanding more than 25 psig without damage by the following calculations based on the methods of the ASME Boiler and Pressure Vessel Code." 
ORNL DWG 75-1045A-2
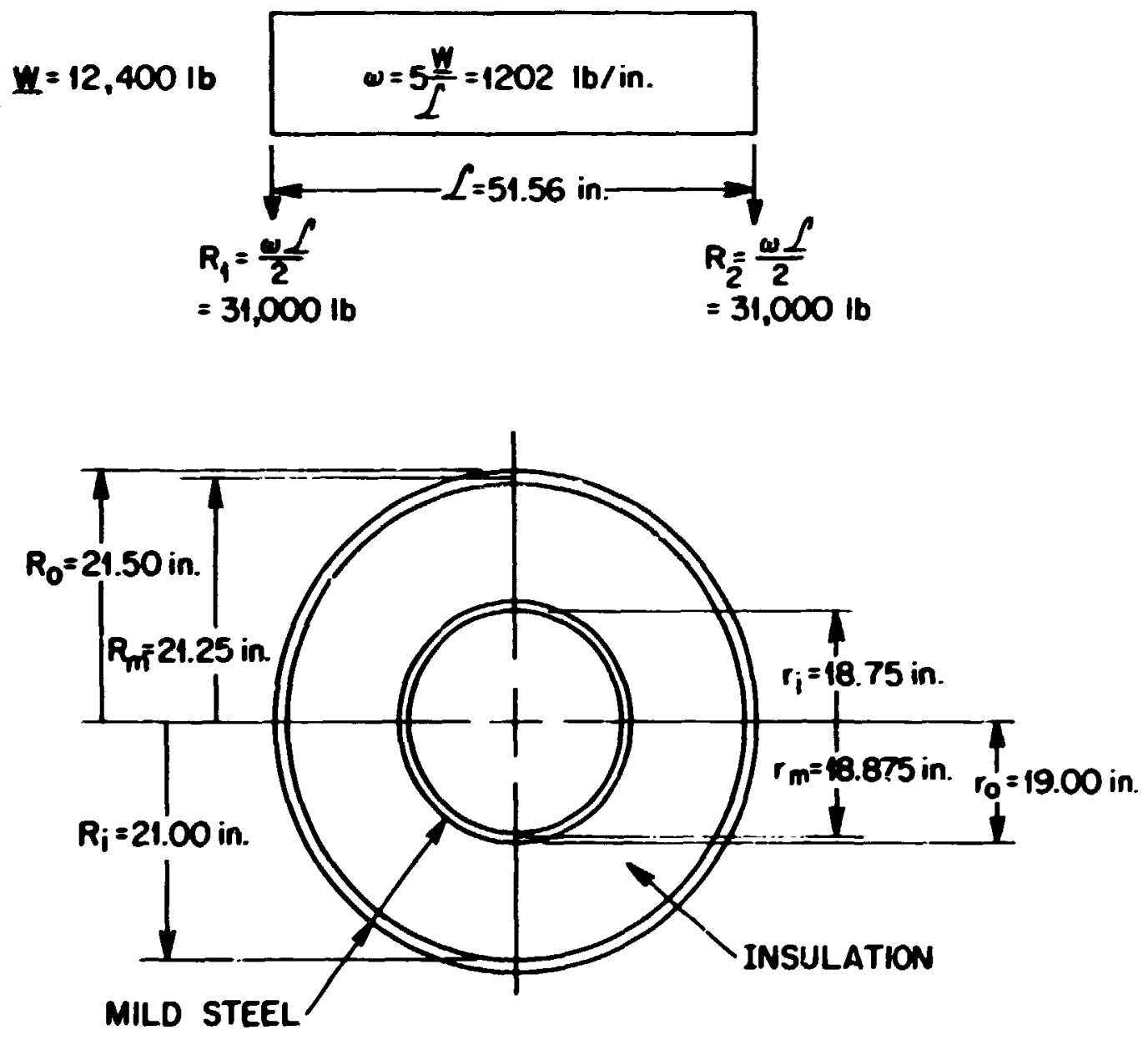

Fig. 18. The fire shield regarded as a simple beam and its equivalent cross section. 
The capability of the outer shell (disrega:ding the lead backup material) to withstand external pressure (Paragraph UG-28:" is calculated as follows:

$$
\begin{aligned}
& L d_{0}=44.25,25.188=-1.76, \\
& D_{.} t=25.188,0.500=59.4 .
\end{aligned}
$$

where

$L=$ inside length of cask, $\mathbf{4 4 . 2 5}$ in.,

$d_{0}=$ outside diameter of cylindrical shell. 25.188 in..

$t=$ shell plate thickness. 0.500 in.,

and the maximum allowable working pressure ( $P$.) at a maximum temperature of $400^{\circ} \mathrm{F}$ is the following:

$$
P_{\text {. }}=\text { B. d. } t=620050.4=123 \text { psi. }
$$

where B $=6200$ from Fig. UHA-28.3 Appendix V."

The capability of the flat top of the cask (disregarding the lead backup material) to withstand external pressure (with reference to Paragraph UG-34 ${ }^{11}$ ) is calculated in the following manner:

$$
P=S t^{2} d^{2} C=11.000(1.5)^{2}(25.188)^{2}(0.25)=24.750158 .6=156 \mathrm{psi} .
$$

where

$$
\begin{aligned}
& \mathbf{P}=\text { design pressure, psi, } \\
& \mathbf{S}=\text { maximum allowable strexs value, } 11,000 \text { psi (at } 400^{\circ} \mathrm{F} \text { ). } \\
& t=\text { plate thickness, } 1.5 \text { in.. } \\
& d=\text { inside diameter head, } 25.188 \mathrm{in} . \\
& C=\text { constant, } 0.25
\end{aligned}
$$

Since the maximum allowable working pressure on the shell and head of the cask exceeds 25 psig, it is concluded that the arrier exceeds the requirements of the structural standards for external pressure. 


\section{S. COMPLIANCE WTTH STANDARDS FOR NORMAL CONDITIONS OF TRANSPCRT}

The regulations stipubte that a single pactage must be able to withstand the normal conditions of traspont without substantially reducing the effectiveness of the package and without relasing radicactive material from the containment vessel. The contents of the container are limited so that the package will contain no gases or vapors that could reduce the effectiveness of the peckaging. No circulating coolant other than atmospheric air is used, and no mechanial cooling device is required or provided. The Garden Carrier No. 2 and its inner containers are designed so that the contents will not be vented to the almosphere under normal conditions of transpurt. These normal conditions include the effects of heat, cold. pressure, free drop, and penetrations.

\subsection{Heat}

The package must be able to withstand direct sunlight at an ambient temperature of $130^{\circ} \mathrm{F}$ in still air without reducing the effectiveness of the packaging. The reguiations' ${ }^{12}$ set forth by DOT further stipulate that the temperature of any accessible surface of the fully loaded shipping package shipped by common carrier shall not exceed $122^{\circ} \mathrm{F}$ or being transported on a sole-use vehicke shall not exceed $180^{\circ} \mathrm{F}$ when the package is in the shade in still air at ambient temperature. For this later evaluatinn, ambient temperature was assumed to be $100^{\circ} \mathrm{F}$. A modified version of HEATING- $3^{13}$ cemputer program was used to compute the steady-state temperature distribution in the cask and its contents under the specified conditions.

\section{I.I Thermal properties of materials}

The thermal properties of materials used to compute the temperature distribution are listed in Table 6.

Thermal properties of Kdowool insulation was obtained from the manufacturer. Bahcack and Wilcox. Thermal properties of all other materials were determined from standard texts.

\subsubsection{Thermal model for iransport of solids}

The model used for the heat-transfer computations for solids shipment is illustrated in Fig. 19. The contents were modeled as a homogeneous cylinder occupying $25 \%$ of the available cavity volume. The thermal conductivity of the source was assumed to be ten times the thermal conductivity of water (see Table 6). This will provide a relatively uniform temperature distribution over a small section of the inner container which is similar to what might be encountered in shipping large pieces of source material. A thermal conductivity more nearly typical of metal, powders, etc. would give iruer source temperatures but would not affect the container, cask, or fire-shield temperatures. Physical properties of stainless steel and the maximum decay heat load of $100 \mathrm{~W}$, uniformly distributed, were used for the contents. 
Table 6. Naterlal properties of materlals of construction used in thermal analysis

\begin{tabular}{|c|c|c|c|c|c|}
\hline Material & $\begin{array}{c}\text { Temperature } \\
(\mathrm{O} F)\end{array}$ & $\begin{array}{l}\text { Thermal conductivity } \\
\left(B t u / h r-f t-{ }^{\circ} \mathrm{F}\right)\end{array}$ & $\begin{array}{l}\text { Density } \\
(1 \mathrm{~b} / \mathrm{in} .3)\end{array}$ & $\begin{array}{c}\text { Heat } \\
\text { capac1ty } \\
\left(B t u / 1 b-{ }^{\circ} \mathrm{F}\right)\end{array}$ & $\begin{array}{c}\text { Latent heat } \\
\text { (Btu/1b) }\end{array}$ \\
\hline Lead & $\begin{array}{r}32.0 \\
212.0 \\
392.0 \\
572.0 \\
621.3\end{array}$ & $\begin{array}{l}20.10 \\
19.00 \\
18.00 \\
18.00\end{array}$ & 0.4109 & 0.031 & 11.3 \\
\hline SSI 304 & $\begin{array}{r}32.0 \\
260.3 \\
440.3 \\
620.3 \\
752 \\
800.3 \\
980.3 \\
1160.0\end{array}$ & $\begin{array}{r}8.50 \\
9.80 \\
10.60 \\
11.40 \\
\\
12.20 \\
13.00 \\
13.80\end{array}$ & 0.2824 & $\begin{array}{l}0.12 \\
0.135\end{array}$ & \\
\hline Kaowool (Insulation) & $\begin{array}{r}400.0 \\
600.0 \\
800.0 \\
1000.0 \\
1200.0 \\
1400.0 \\
1600.0\end{array}$ & $\begin{array}{l}0.0250 \\
0.0375 \\
0.0517 \\
0.0692 \\
0.0833 \\
0.1100 \\
0.1367\end{array}$ & $3.47 \times 10^{-3}$ & 0.255 & \\
\hline Aluminum & $\begin{array}{r}32.0 \\
212.0 \\
392.0 \\
572.0 \\
752.0 \\
932.0 \\
1112.0\end{array}$ & $\begin{array}{l}117.00 \\
119.00 \\
124.00 \\
133.00 \\
144.0 \\
155.0\end{array}$ & $9.78 \times 10^{-2}$ & $\begin{array}{l}0.2106 \\
0.2225 \\
0.2344 \\
0.2463 \\
0.2582 \\
0.2702 \\
0.2821\end{array}$ & \\
\hline
\end{tabular}




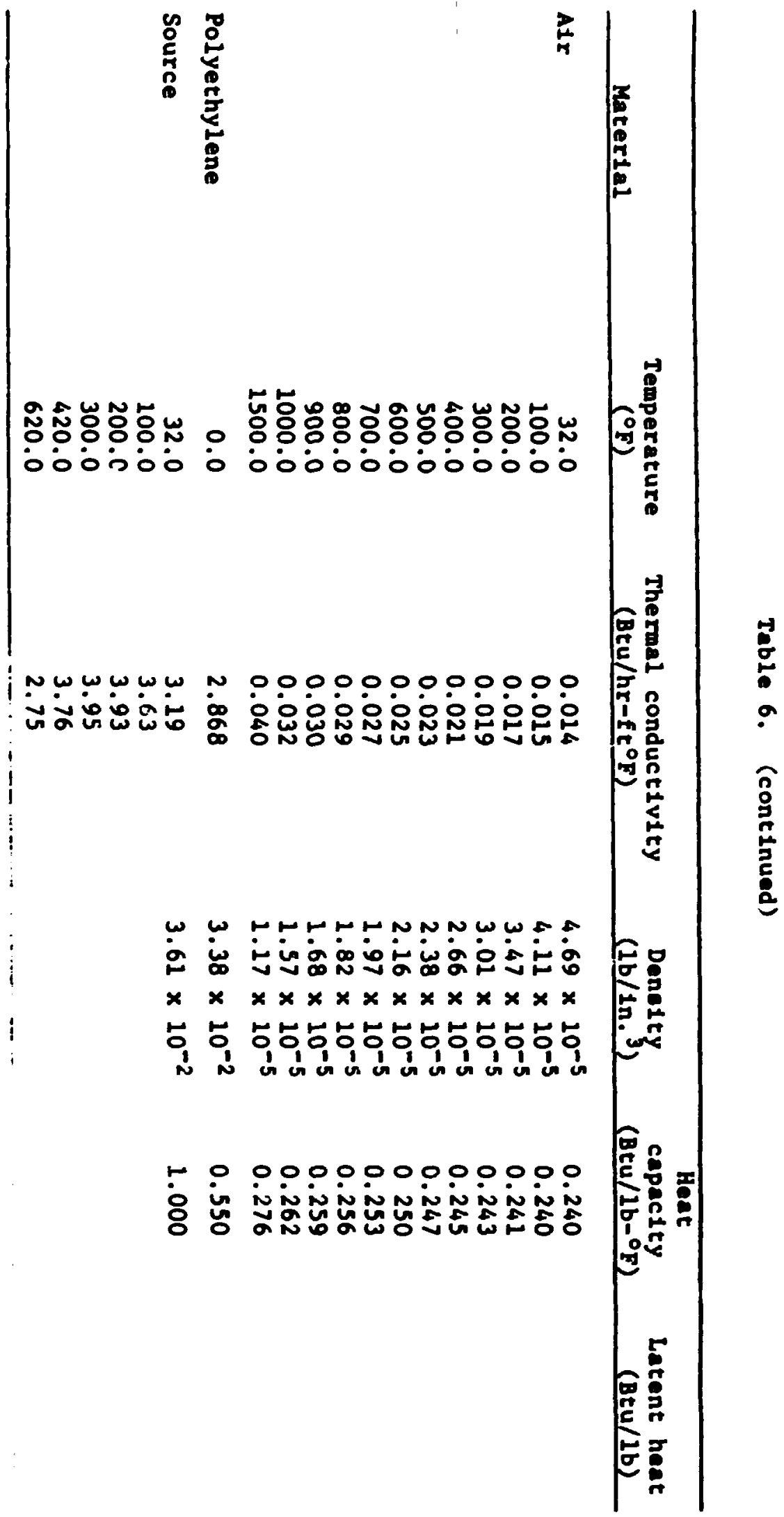




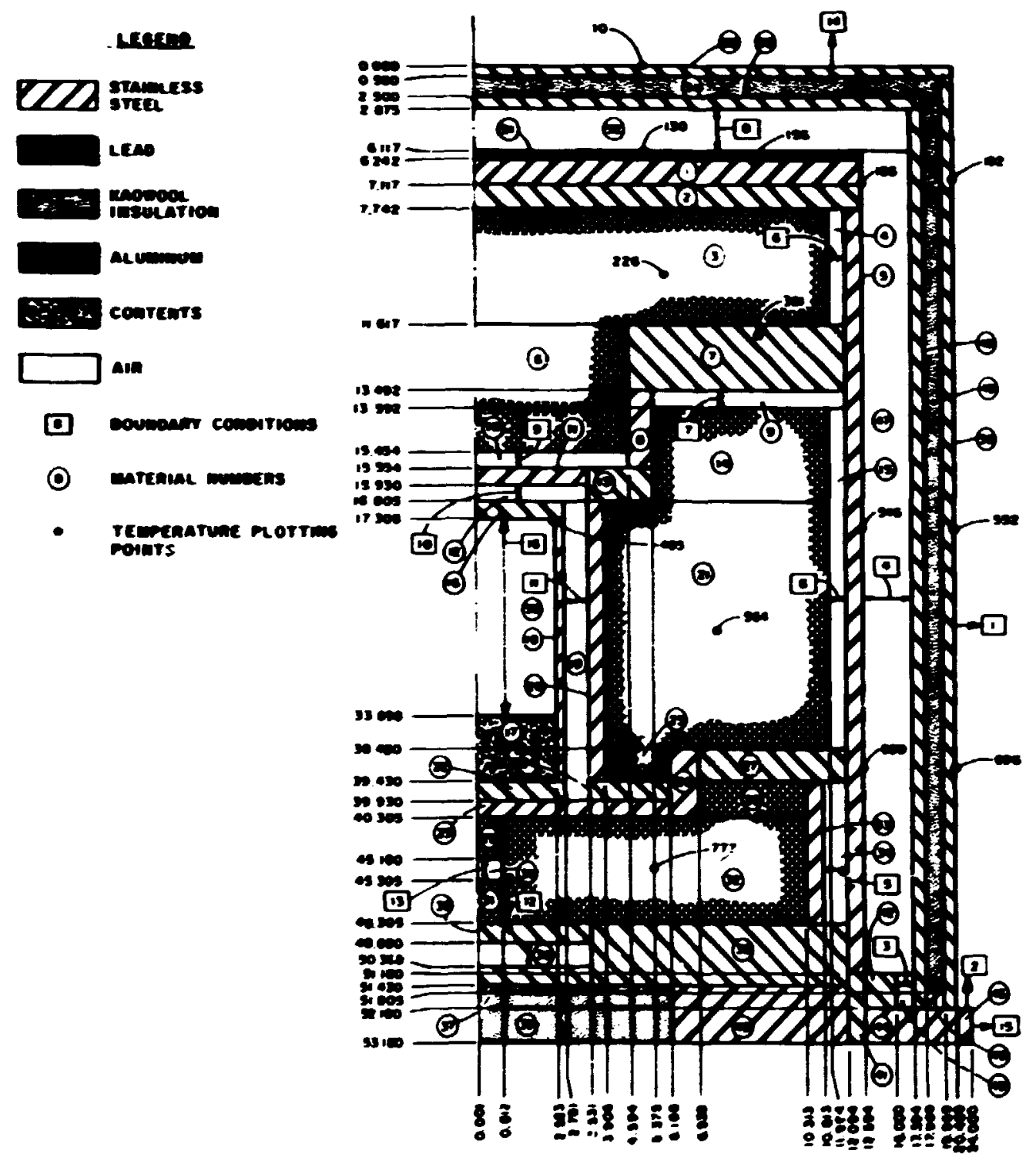

Fig. 19. Computational sodel to determine the effects of thermal tests on Garden Carrier No. 2 when carrying solids. 
The sliding doors were modeted as a cylinder of lead encased in stainless steel. Internal air gaps associnted with the door ar: sngement were incorporated into a single air gap external to the steet cylinder. Region 34 in the HEATING-3 model. Fig. 19. The bottom of the cask was assumed to be insulated because insulation material will be secured in the stid.

it was determined tiat matural convection, in addition to radiation and conduction, was a significan mode of beat transfer in the interior air gaps represented by Regions 12, 19, 34, 36, 43. 47. 52 and 56 in the HEATING-3 model. Natural convection was neglected in the remaining internal air gaps. laving radiation and conduction as the onty modes of heat transfer across these air gaps. Internal convection is assumed to be significant if the Raykigh number $\left[R_{a}=\left(p^{2} a C_{p}\right.\right.$ ikt $\left.)(\Delta T L)\right]$ based on the gap size, $L$ is greater than 1000 .

In calculating the steady-state temperatures for the $1300 \mathrm{~F}$ environment in direis zunlight, it was ascumed that $144 \mathrm{Bro} / \mathrm{hr}-\mathrm{fl}^{2}$ was incideat upon the projected area of the cask. This projected area, $18.75 \mathrm{ft}^{2}$, is the maximum area that conld be exposed to direet sunlight at any time regardless of the position of the cask to the sun. The fraction of the ixcidert sotar flux that is adosorbed by the cast is equal to the absopptivity of the outer surface of the cask, estimated to be 0.6. The tocal cneray absorted was assumed to be evenly distributed over the actul are of the top and sides of the cask. The bottom of the cask was assumed to be insulated. For an absorptivity of 0.6. the net hux absorbed over the actual noninsulated surface aree is $26.5 \mathrm{Bru} / \mathrm{hr}-\mathrm{fi}^{2}$.

\subsubsection{Maxinum ermperatures}

Calculated temperatures at points of interest within the cask are presented in Tabte 7 for the $130^{\circ} \mathrm{F}$ environment in direct sunlight as well as for the $1000 \mathrm{~F}$ environment in shade. The cakculations are for the solids shipment with the decay heat load being $100 \mathrm{~W}$. The maximum accessible surface temperature for the $100 \mathrm{~F}$ environment was calculated to be $114^{\circ} \mathrm{F}$, less than the limit of $122^{\circ} \mathrm{F}$ specified by applicable regubtions. Since all temperatures are below both the metring point of lead and the termperature at which polyethylene is damaged. calculations for the liquid load. which has only a $20-\mathrm{W}$ heat source (maximum). were not made. Since the temperatures are well within the operating limits of the gaskets and seals, the integrity of the cask and its inner container will be unaffected by these therinal boundary zonditions. Therefore, the coneainer complies with the regulations.

\subsection{Cold}

The shipping package must he able to withstand an ambient temperature of $-40 \mathrm{~F}$ in still air and shade.

Taking $T_{1}:=-40^{\circ} F(4200 R)$ and ascuming no internal heat load, the funal or maximum pressure $\left(P_{2}\right)$ in any cavity sealed at a pressure of 14.7 psia and a temperature of $70^{\circ} \mathrm{F}\left(550^{\circ} \mathrm{R}\right)$ is:

$$
P_{2}=\left(P_{1} T_{2}\right) / T_{1}=11.65 \text { psia. }
$$


Table 7. Maximum selected temperature. for solid shipment thermal analysis

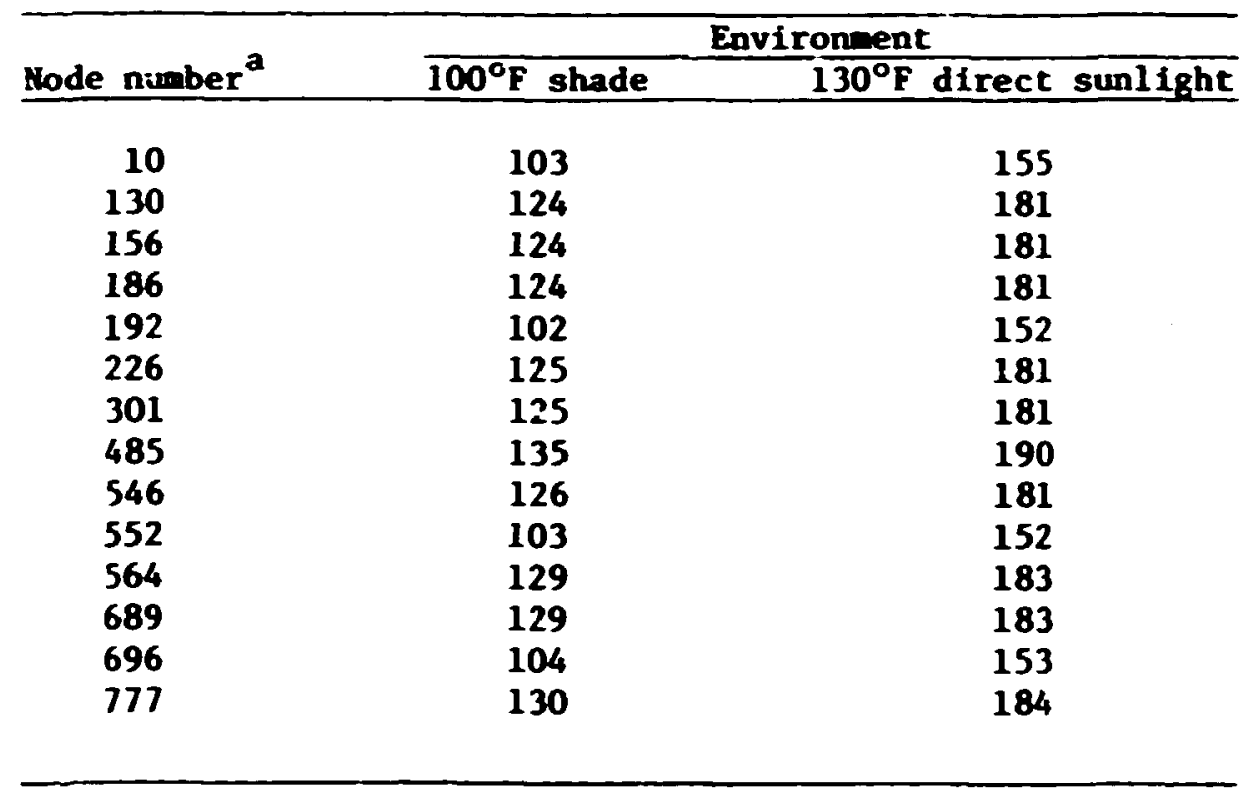

$a_{\text {See Fig. } 19 .}$ 
The resulting pressure differential is less than the 25 psiz differential pressure investigated in Sect. 4.2. A eemperature of $-100 \mathrm{~F}$ is within the operating temperature range of the seals and the 300 series stainless steel cbaddine. structural components, and fasteners which make up the ast. Britte fracture of these components under the stipubted cold condition is not likely because the temperatures of these components are above their ductik-to-britte transition temperatures. The fire stield and stid, madi of mild steel, are not considered a pan of the containment.

The preceding consideretions undicate that the stipulated cold conditions will not reduce the effectiveness of the packaging. and that the container conforms to the requirements for the cold condition of normal transport.

\subsection{Pressure}

The regulations for normal conditions of transport specify that the package should be able to withstand an atmosphesic pressure of 0.5 times the standard atmospheric pressure. with the resulting pressure being 7.3 psin.

When the model is under full heat load. trapped air in the cavity will expand and exert internal pressures. Asouming assembly at $700 \mathrm{~F}$ and 14.7 psin. the resulting pressure of any trapped air is:

$$
P_{2}=\left(P_{1} T_{2}\right): T_{1}=(14.7)(650) 530=18.0 \text { psLa }(3.3 \text { psig })
$$

where

$$
\begin{aligned}
& P_{1}=\text { assembly pressure, } 14.7 \text { psia. } \\
& T_{2}=\text { temperature under heat load. } 650^{\circ} \mathrm{R}\left(190^{\circ} \mathrm{F}\right) \text {. } \\
& \mathrm{T}_{1}=\text { assembly temperature, } 530^{\circ} \mathrm{R} .\left(70^{\circ} \mathrm{F}\right) .
\end{aligned}
$$

The cask and its gasketed seals will be able to withstand this pressure without damage or reduction in effectiveness of the packaging. and the container conforms to the requirements for the reduced pressure condition of normal transpon.

The pressure increases in the internal air gaps were estimated using ideal gas law, assuming constant volume, a sealing temperature, $T_{1}$, of $70^{\circ} \mathrm{F}\left(530^{\circ} \mathrm{R}\right)$, and a sealing pressure, $P_{1}$. of 14.7 psia. The final pressure, $P_{3}$, can be expressed in terms of the final temperature. $T_{2}$ and the initial conditions, $P_{1}$ and $T_{1}$, as

$$
\mathbf{P}_{2}=\mathbf{P}_{1}\left(\mathbf{T}_{\mathbf{2}} / \mathbf{T}_{\mathbf{1}}\right)
$$

The internal pressures associated with the intemal air gaps for the $100 \mathrm{~F}$ shade 
environment. for the $130^{\circ} \mathrm{F}$ direct sunlight environment, ar: presented in Table 8 for a decay heat load of $100 \mathrm{w}$.

\subsection{Vibration}

The package is of weldev construction. and therefore vibrations received in transit are not expected to affect its integrity. In addition. the cask. which was built several years ago, has operated in the transportation environment and has suifered no ill effects as a result of the vibrations that were encountered.

\subsection{Water Spray}

The containment capabilities of the Garden Carrier No. 2 are ant compromised by water spray, since all external surfaces of the fire shield are of steel and the cask is made of stainless steel. The closure seal is impervious to water.

\subsection{Free Drop}

The regulations for normal conditions of transport require that a package weighing between 10.000 and $20.000 \mathrm{lb}$ be capable of withstanding a free drop through a distance oi $3 \mathrm{ft}$ onto a flat. essentially unyiebling. horizontal surface. striking the surface in a position in which maximum damage is expected to result. A free drop of the Garden Carrier No. 2 through a distance of $3 \mathrm{ft}$ is expected to produce only minor denting of the outside steel shell of the cask itself. If th: package were dropped 3 ft and minor repairable external damage did occur, the effectiveness of the package would not be reduced. (See the analysis of the 30-ft free-fall. Sect. 6.1).

\subsection{Penetration}

The regulations for normal conditions of Iransport stipulate that the package must be capable of withstanding the impact of the hemispherical end of a vertical steel cylinder that weighs $13 \mathrm{lb}$. has a 1-1 4-in.diam, and is dropped from a height of $40 \mathrm{in}$., normally onto the exposed surface of the package that is expected to be the most vulnerable to puncture.

The outer shell of the fire shield is 12 in.thick steel. Tests conducted on $1 / 2$ in. thick stainless steei have shown that the damage produced by the 13-1b steel cylinder beirig dropped through a distance of 40 in. will be negligible and the effectiveness of the fire sinield will not ive reduce.t. 
Table 8. Pressures in internal air gaps for $100-W$ load

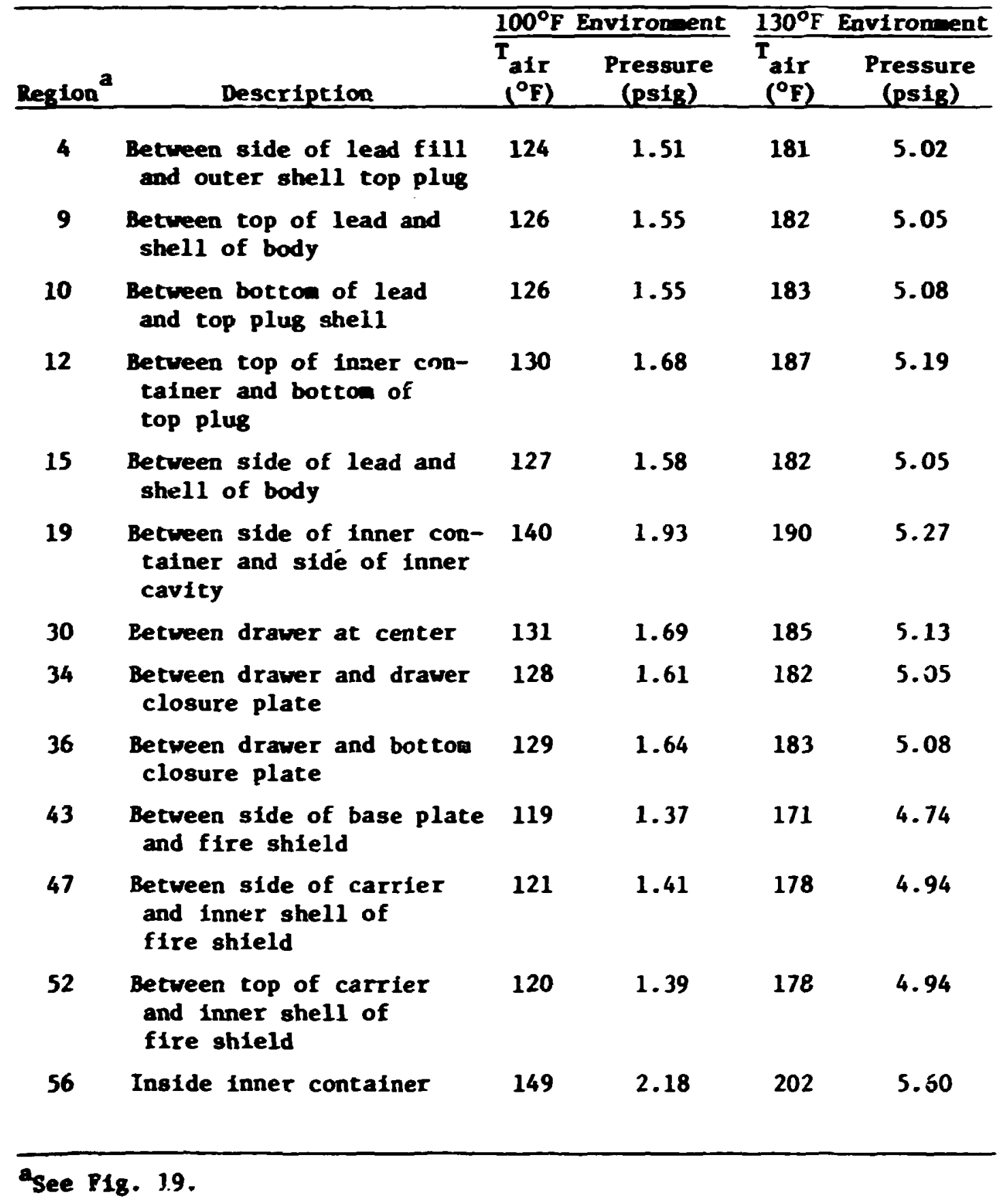




\subsection{Compression}

Since the Garden Carrier Yo. 2 weighs over $10.000 \mathrm{lb}$. this section of the regulations does not apply.

\section{COMPLIANCE WITH STANDARDS FOR HYPOTHETICAL ACCIDENT CONDTIONS}

The standards for the hypothetical accident conditions stipulate that a container used for the shipment of large quantities of fissike or radioactive material shall be designed and constructed in such a manner and its contents limited so that. if it is sibjected to the specified free drop. puncture. thermal, and water immersion conditions. the following standards will be met:

(1) The reduction in shielding would not be sufficient to iacrease the extemal radiation dose rate to more than $1000 \mathrm{mR}$ hr at a distance of 3 ft from the outside surface of the package.

(2) No radioactive material would be released from the packagt except for gases containing totai radioactivity not to exceed $0.1 r_{r}$ of the total radioactivity of the contents of the package.

(3) The contents would remain subcritical.

\subsection{Free Drop}

The first in the sequence of hypothetical accident conditions to which the cask must be subjected is a free drop through a distance of $30 \mathrm{ft}$ onto a fat. essentially unyieluing. horizontal surface. striking the surface in a position in which the maximum damage is expected to occur.

The Garden Carrier vo. 2 is covered by the fire shield hefore being shipped. Damage in the package will be evaluated by assuming it impacts the unyielding surface with the following impact orientations and conditions:

1. A corner drop will be made on the fire shield.

2. A side drop will he made on the fire shield.

3. Using the negative accelerations determined by the corner and side drops. the ability of the bolts to restrain the top plug and the drawer will be demonstrated. 


\subsubsection{Impact on top comer}

A computational analysis (see Appendix C) was applied to a simplified cylindrical cask model to estimate the deformation resulting from a 30-ft comer drop isce Fig. 20) with its line of action through the center of gravity. Resuits shown in Tabie 9 indicate by usiug specific energies of steel that vary from 100,000 to 260,000 in.-lb in. ${ }^{3}$, the deformation would vary from 2 to 1.4 in.; this deformation would occur primarity in the steel because of the large bending area between the steel, the wood distributor ring, and the carrier.

\subsubsection{Impact on side}

A computational analysis (see Appendix D) was applied to a simplified cylindrical cask model to estimate the deformation resulting from its impact on the side such that the edge of the skid and the top comer of the fire shield hit the immovable surface simultaneously (see Fig. 21). Some of the impact forces will be dissipated in bending the skid; however. the bending of the skid elements is being disregarded and all of the energy is assumed to deform the fire shield. The skid odge is a 6-in. by 6-in.-wide flange which has a 0.269-in-thick flange. Results shown in Table 10 indicate that the deformation would vary between 1.4 to 1.0 in. when using specific energies of steel that vary from 100,000 to 260,000 in.-lb/ in ${ }^{3}$.

\subsubsection{Bolts holding drowers}

A side drop in which the axis of the drawers would be vertical would place the bolts securing these drawers under the greatest strain.

Each drawer is restrained during transit iy eight $3 / 8$-in. by $3 / 4$-in. long (16 NC-2) hex-head stainless steel cap screws which hold the face of the drawer onto the cask body. In addition, the drawer movement is restrained by two 13/32-in.diam dowel ends on the stainless steel socket-head cap screws which hold the drive nut on the screw. After the two dowel ends are sheared off and the eight screws fail, the line of containment for the drawer would be a gasketed cover secure by twenty $1 / 2$-in.- by $1-1 / 4$-in.-long $(13 \mathrm{NC}-2)$ socket-head stainless steel cap screws.

Using the largest negative acceleration in Table 10 and applying it to the weight of the drawer, the force, $F_{p}$ is determined as foilows:

$$
F_{p}=W_{d} \times g=335 \times 1046=350,410 \mathrm{lb} \text {. }
$$

where

$$
\begin{aligned}
& \mathbf{W}_{\mathcal{\prime}}=\text { weight of drawer, } 335 \mathrm{lb}, \\
& \mathbf{g}=\text { negative acceleration, } 1046 .
\end{aligned}
$$


ORNL OWE $75-1111$ R-I
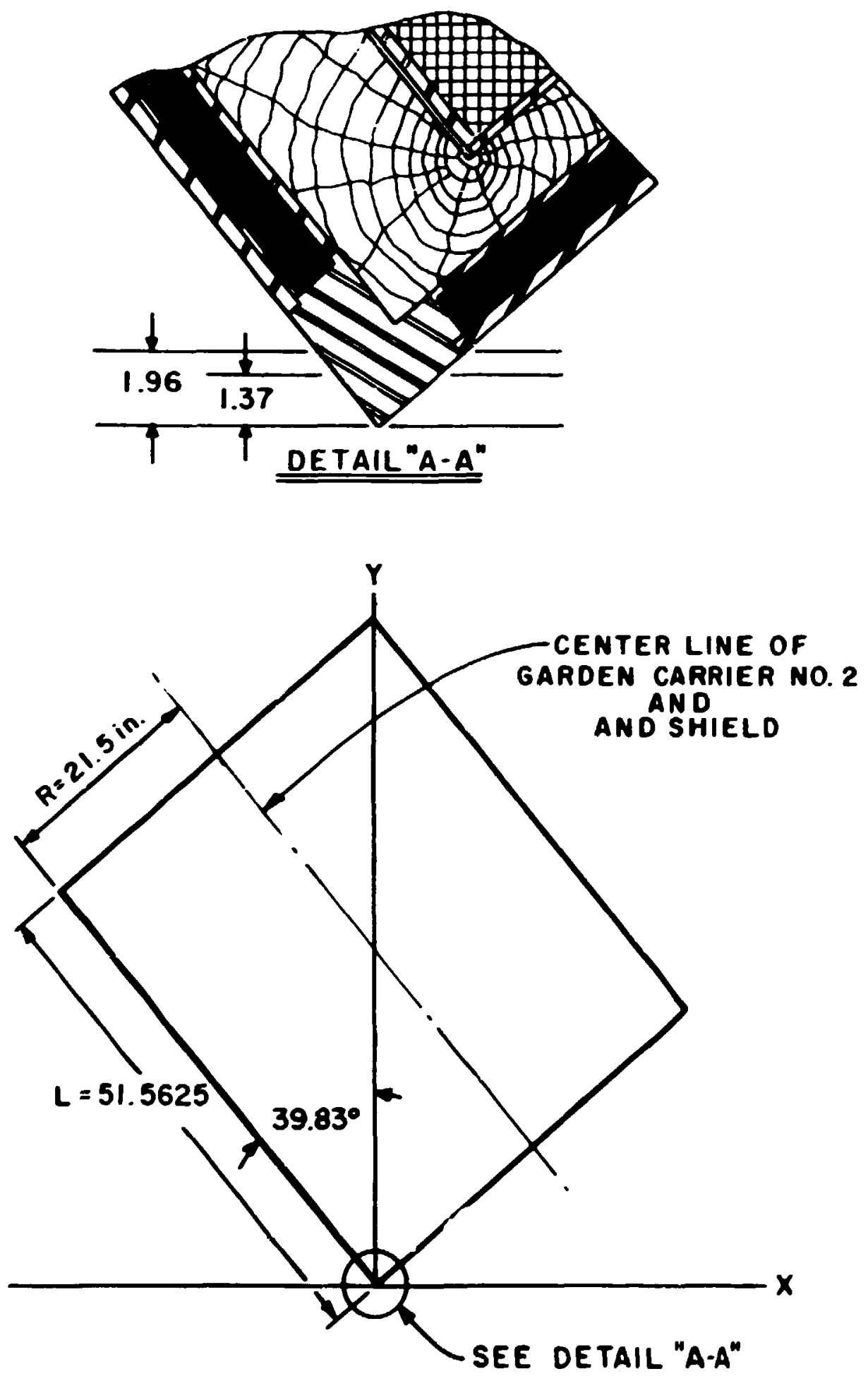

F18. 20. Deformation geometry for corner impact orientation of. Garden Carrier No. 2 in its fire shield. 
Table 9. Impact on top corner - maximum negative acceleration and deformation resulting from high and low values of specific energy in steel

\begin{tabular}{ccc}
\hline $\begin{array}{c}\text { Specific energy } \\
\text { (in.-1b/in. } 3 ;\end{array}$ & $\begin{array}{c}\text { Haxinu deformation } \\
\text { corner drop } \\
\text { (in.) }\end{array}$ & $\begin{array}{c}\text { Haximimative } \\
\text { acceleration } \\
\text { (8) }\end{array}$ \\
\hline 100,000 & 1.96 & 474 \\
260,000 & 1.37 & 724 \\
\hline
\end{tabular}

Table 10. Impact on side - maximum negative acceleration and deformation resulting from high and low values of specific energy in steel

\begin{tabular}{ccc}
\hline $\begin{array}{c}\text { Specific energy } \\
\left(\text { in. }-1 \mathrm{~b} / \text { in. }^{3} \text { ) }\right.\end{array}$ & $\begin{array}{c}\text { Maximum deformation } \\
\text { corner drop } \\
\text { (in.) }\end{array}$ & $\begin{array}{c}\text { Maximum negative } \\
\text { acceleration } \\
\text { (8) }\end{array}$ \\
\hline 100,000 & 1.36 & 693 \\
260,000 & 0.95 & 1046 \\
\hline
\end{tabular}


ORNL DWG 75-4907
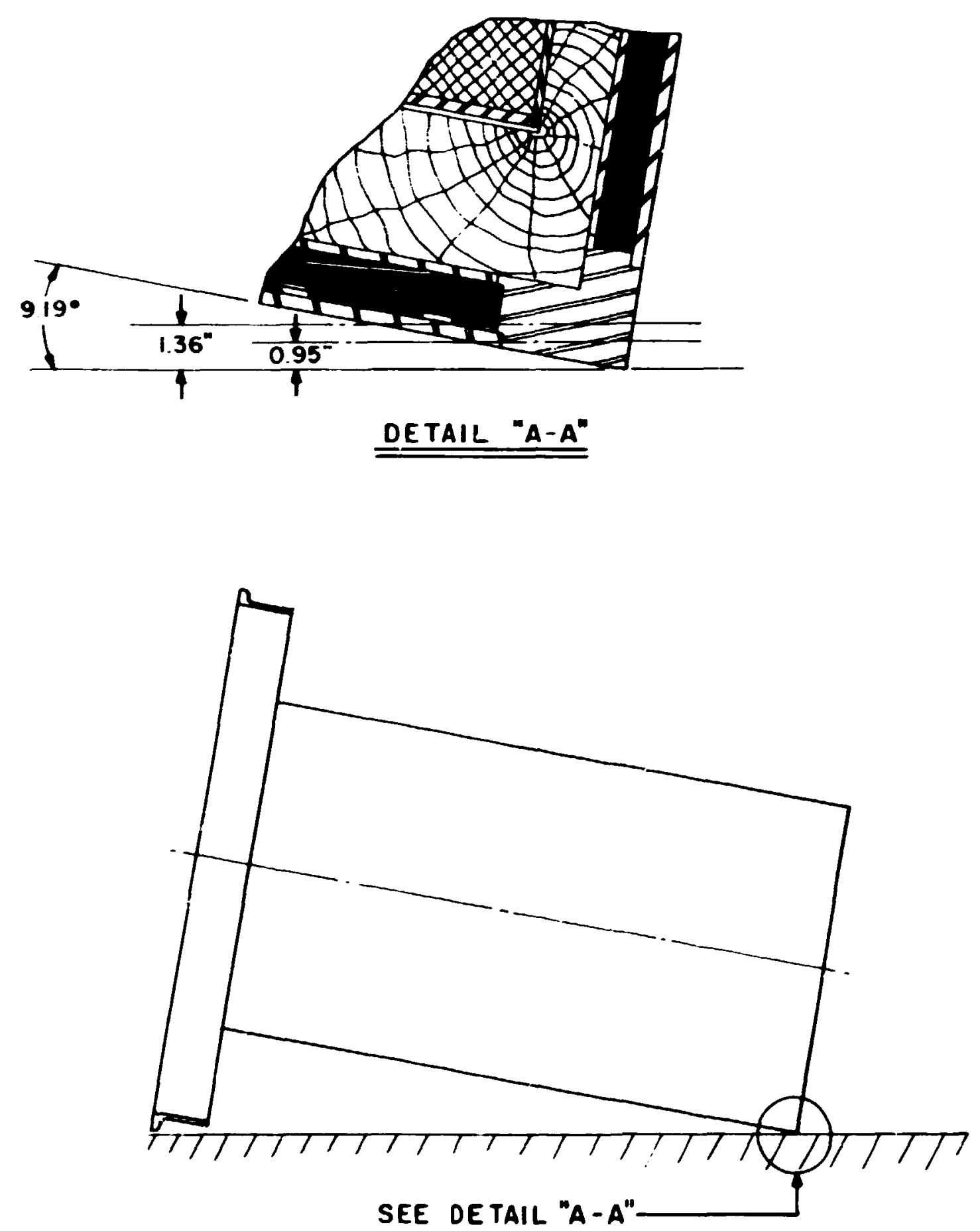

Fig. 21. Deformation geometry for side impact orientation of Garden Carrier No. 2 in its fire shield. 
The force. $F_{m}$ is applied to the cask in a direction of the drop. The component $F$, of that force appliod along the axis of the bolts and the drawer is found as follows:

$$
F_{t}=F_{,} \cos \theta=350.410(0.987)=346.000 \mathrm{lb} \text {. }
$$

where

$\theta=$ angle between axis of bults and drawers and impact surface. $9.19^{\circ}$.

The force which the eight 3/8-in. cap screws will resist, $F_{3}$ is found as follows:

$$
F_{s}=N S_{w}=8(12,000)=96,000 \mathrm{lb} \text {. }
$$

where

$N=$ number of screws, 8 ,

$S_{*}=$ peak force for 3/8-in. cap screws. 14 12,000 lb.

The force which the two dowel ends will shear, $F_{\alpha}$ is found as follows:

$$
F_{d}=N \pi d^{2} 4 r_{-}=2 \pi(13 ; 32)^{2}(61,000) 4=15,800 \mathrm{lb} .
$$

where

$N=$ number of dowels, 2 .

d = diameter of dowel ends. $13 / 31$ in.

The force that the twenty 1/2-in. socket-head screws will resist, $F_{M}$, is found as follows:

$$
F_{H} \mathrm{NS}_{w}=20(18,300)=366,000 \mathrm{bb}[-346,000 \mathrm{lb} \text {, see Eq. }(112)] \text {. }
$$

where

$$
\begin{aligned}
& N=\text { number of screws, } 20 . \\
& S_{a}=\text { yield force for } 1 / 2 \text {-in. screws, } 18,300 \mathrm{lb} .
\end{aligned}
$$

The twenty sccket-head cap screws that hold the drawer cover plate will, therefore, retain the drawer in the cavity. As a safeguard, a wcod filler block is located on the inside of the fire shield in front of each of the two drawer closures ( $1 / 8$-in. clearance).

If the bolts on the drawer closure were to break, containment would not be lost. since the primary line of containment is the inner container. The ability of the cask to meet the other 
requirements would not be altered.

\subsubsection{Bolts holding top plus}

A drop on the top of the cask (fire shieb) would certainly drive the top plug more firmly into the top of the cask. probably deforming the walls of the top plug extension into its recess such that it would be veny difficult to remove.

A comer drop will be used to demoristrate the behavior of the twetve 3, 4-in. bolts holding the top plug to cask.

Using the largest decekeration in Table 9 and applying it to the weight of the top plug and the contents of the cask. the force. $F_{p}$. is determined as follows:

$$
F_{p}=W, \times g=1340(724)=970,160 \mathrm{lb} .
$$

$$
\begin{aligned}
& W_{p}=\text { weight of top plug plus cask content (see Tabk I). } 1340 \mathrm{lb}, \\
& g=\text { deceleration. } 724 .
\end{aligned}
$$

The force. $F_{p}$. is applied to the cask in the direction of the drop. The component. $F_{a}$ of that force applied along the axis of the bolt and plug is found as follows:

$$
F_{\text {a }}=F_{p} \cos \theta=970.160(0.768)=745,100 \mathrm{lb} \text {. }
$$

where

$\theta=$ angle betw:en axis of bolts and impact surrace, $39.83^{\circ}$.

The maximum force which the twelve 3 4-in. stainless steel bolts can resist before breakage is found as follows:

$$
F_{R}=N S_{u}=12(37.500)=450,000 \mathrm{lb} \text {. }
$$

where

$$
\begin{aligned}
& N=\text { number of bolts, } 12, \\
& S_{2}=\text { peak force for } 3 \text { 4-in. cap screws, }{ }^{14} 37,500 \mathrm{lb} .
\end{aligned}
$$

A wonden block is placed in contact between the top of the cask and the inside of the fire shield. This block will absorb the energy of the top plug and will prevent the bolts from stretching to the point of breakage. This is shown as follows: 


$$
F_{\sigma}=A \text { ot }=430(5390)=2.320 .000 \mathrm{Bb} \text {. }
$$

where

$$
\begin{aligned}
& A=\text { area of wood, } 430 \text { in.? }^{2} \\
& \text { of }=\text { compressive strength elastic limit (see Table ?), } 5390 \text { psi. }
\end{aligned}
$$

Therefore, ahthough the bolts are stressed beyond their yiedd strength. the wooden block will prevent their being stretched to the braking point. Additionally. the wooden block will absorb the residial energy of the impact, and the fire shield will prevent the loss of the top plug shiekding should the bolts fail.

\subsection{Puncture}

The second in the sequence of hypothetical accideme coistitions to which the cask must he subjected is a free drop through a distance of $\mathbf{4 0}$ in. to strike (in a position in which maximum damage is expected) the top end of a verical mild steel bar mounted on an essentially unyielding horizontal surface. The mild steel bar shall have a diameter of 6 in.. with the top horizontal and its edge rounded to a radius of not more than 14 in.: the bar shall be of such kength that it will cause maximum damage to the cask. but not less than 8 in. long. The long axis of this bar shall be normal to the surface of the cask upon impact.

The garden Carrier No. 2 fire shield is fabricated with an outer shell of 0.5-in. stacl and an inner shell of 3/8-in. steel at the top and $1 / 4$ in. on the side. The gap between the outer and inner shells is filled with Kaowool insulation. a soft material that is assumed to provide no support for the outer shell during the puncture portion of the hypothetical accident. A shipping container with a similar type construction was tested. and the drop onto the piston did nor puncture the outer shell. The package that was tested" had a 3 16-in.-thick outer shell and weighed 3,800 lb. The Garden Carrier No. 2 has a 1 2-in.-thick outer shell and weighs 12.400 Ib. which has a comparable weight to the outer shell ratio. It can. therefore. be assumed that the Garden Carrier No. 2 will also pass the puncture test.

\subsection{Thermal Evaluation}

\subsubsection{Hypotherical thermal accident condition discussion}

The third in the sequence of hypothetical accident conditions specified by the regulations to which the cask must be subjected is exposure for $30 \mathrm{~min}$ within a source of radiant heat having a temperature of $1475^{\circ} \mathrm{F}$ and an emissivity coefficient of 0.9 . or equivalent. For calculational purposes, it shall be assumed that the package has an absorption coefficient of 
0.8. The pactage shall not be cooled artificially until after the 30-min test period and the temperature at the center of the pactage has begun to fall. or until $3 \mathrm{hr}$ following the test period.

A modified version of the computer program. HEATING-3." was used to determine the temperature distribution when exposed to these thermal environments.

It was assumed that the cask was loaded with the maximum permissible decay heat bad of $100 \mathrm{~W}$ for shipment of solids. The temperature distribution from the $100 \% \mathrm{~F}$ ambient condition for the $100-W$ intermal heat load was input as the initial temperature distribution for the accident (fire) cakulations.

The damage irom the free drop and puncture portions of the hypothetical accident would not adversely affect the performance of the container in the hypothetical thermal accident. Hence the undamaged configuration was assumed.

\subsubsection{Thermal propertics of materials}

The thermal properties of materials used to compute the tempetature distribution under steady-state and transient conditions are listed in Table 6 (see Sect. S.1.1).

\subsubsection{Thermal accident analysis}

Tree computational model previously used and described in Sect. 5.1.2, representing half of the container. was also used for the thermal accident analysis. The HEATING-3 computer program was used to determine the temperature distribution in the container that would result from the prescribed 30-min thermal exposure. The material constants given in Table 6 were used in the calculations: 2 description of the tratment of heat transfer across the gaps is given in Sect. 5.1.2. The steady-state temperature distribution computed for the heat condition of normal transport (100 F ambient shade with $100-W$ source) was taken as the starting point. A 100-W internal heat generation was used for the trarsient analysis. The case for liquids with a 20-W internal genisation rate was not investigated. since the 100-W case is conservative. and all temperatures were found to be satisfactory.

\subsubsection{Temperatures as result of the thermal accident analysis}

Cask temperatures were followed for $3 \mathrm{hr}$ after the conclusion of the fire. since regulations specify that the cask cannot be artificially conled prior to this time unless the temperature in the center of the cask has begun to fall.

A plot of the temperatures in three different areas of the cask was made for the duration of the run and are presented. Figure 22 shows how the temperature varies from the side. The temperature for node 552 (see Fig. 19), which is located on the outside surface of the fire shield approximately half way up the side, responds to the fire condition. heating up to $1375^{\circ} \mathrm{F}$ and cooling down rapidly. The temperatures on the outside of the body of the carrier (node 


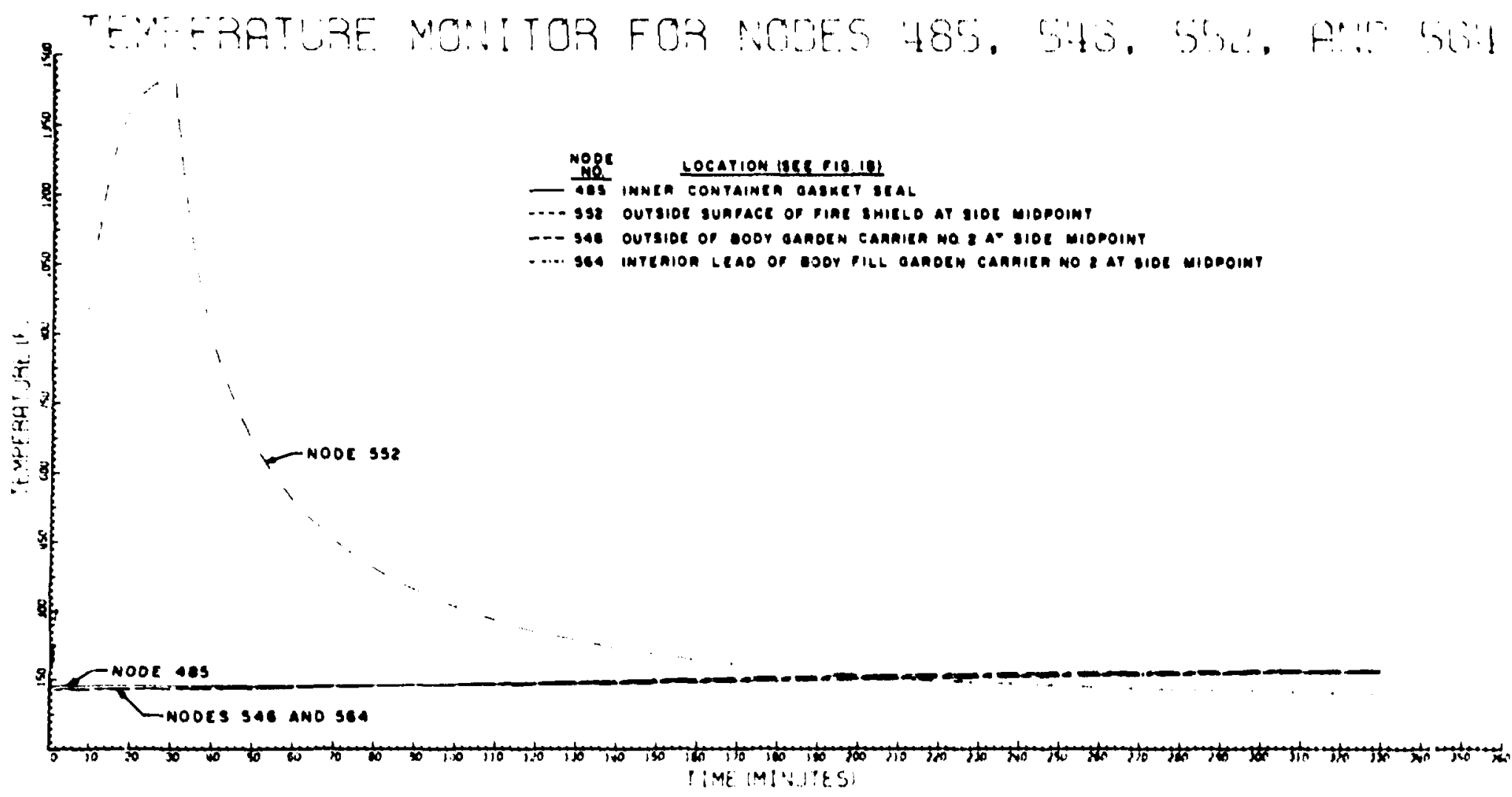

F18. 22. Temperatures on varlous points through the side of the Garden Carrier No. 2 shipping assembly as determined during and after the thermal accident conditions. 
546). the interior of the lad fill (node 545; and the gasket of the inner container (node 485) were at essentially the same temperatures. $166^{\circ} \mathrm{F}$. at the end of $3 \mathrm{hr}$ (see Fig. 23). The iemperatures at the top of the assembly (see Fig. 23) show a maximum temperature in the lead (node 226) and the outside of the carrier (node 130) of approximately :55 $\mathrm{F}$ at the end of 3 hr. The temperatures in the drawer and drawer closure gasket are shown in Fig. 24. These temperatures are approximately $180^{\circ}$ at the end of $3 \mathrm{hr}$.

The maximum centerline temperature remained at approximately $184^{\circ} \mathrm{F}$ throughout the $30-\mathrm{min}$ test period and rose to approximately $220^{\circ} \mathrm{F}$ at the end of the $3 \mathrm{hr}$ cool down (the maximum cask temperature was $230^{\circ} \mathrm{F}$ ). With no artificial cooling. the maximum centerline temperature rose to $230 \mathrm{~F}$ after $5 \mathrm{hr}$ of cool down which was also the maximum cask temperature.

The temperatures of that magnitude (230 F max) will have no deketerious effects on any of the gaskets nor un a poiyethylene bottie used inside the inner container.

Consequently, if the cask is subjected to the high-temperature thermal environment, it is capable of withstanding it with no loss of contents and. therefore. meets this part of the regulations.

\subsubsection{Maximum internal pressures}

The maximum pressures associated with the internal air gaps as a rest:lt of the thermal accident were estimated (see Table II) using the same ideal relatives as before (see Sect. S.3).

Maximum internal pressures of this magnitude $(5.3 \mathrm{psig}$ ) will have no dekterious effect on the shipping cask.

\subsection{Water Immersion}

The fourth in the sequence of hypathetical accident conditions to which the cask must be subjected is immersion in water in such a manner that all portions of the package are under at least $3 \mathrm{ft}$ of water for a period of not less than $8 \mathrm{hr}$.

The gaskets of the cask and the inner container will not have been damaged. The integrity of the cask and the inner containers after the 30-ft frec-fall and fire test should be inviolate. The moderation afforded by the water is not determined (see Sect. 9).

\section{CONTAINMENT}

The radioactive material shipped in the Garden Carrier No. 2 is contained inside an inner container. The test and evaluation of the inner containers is described in Sect. 8. 


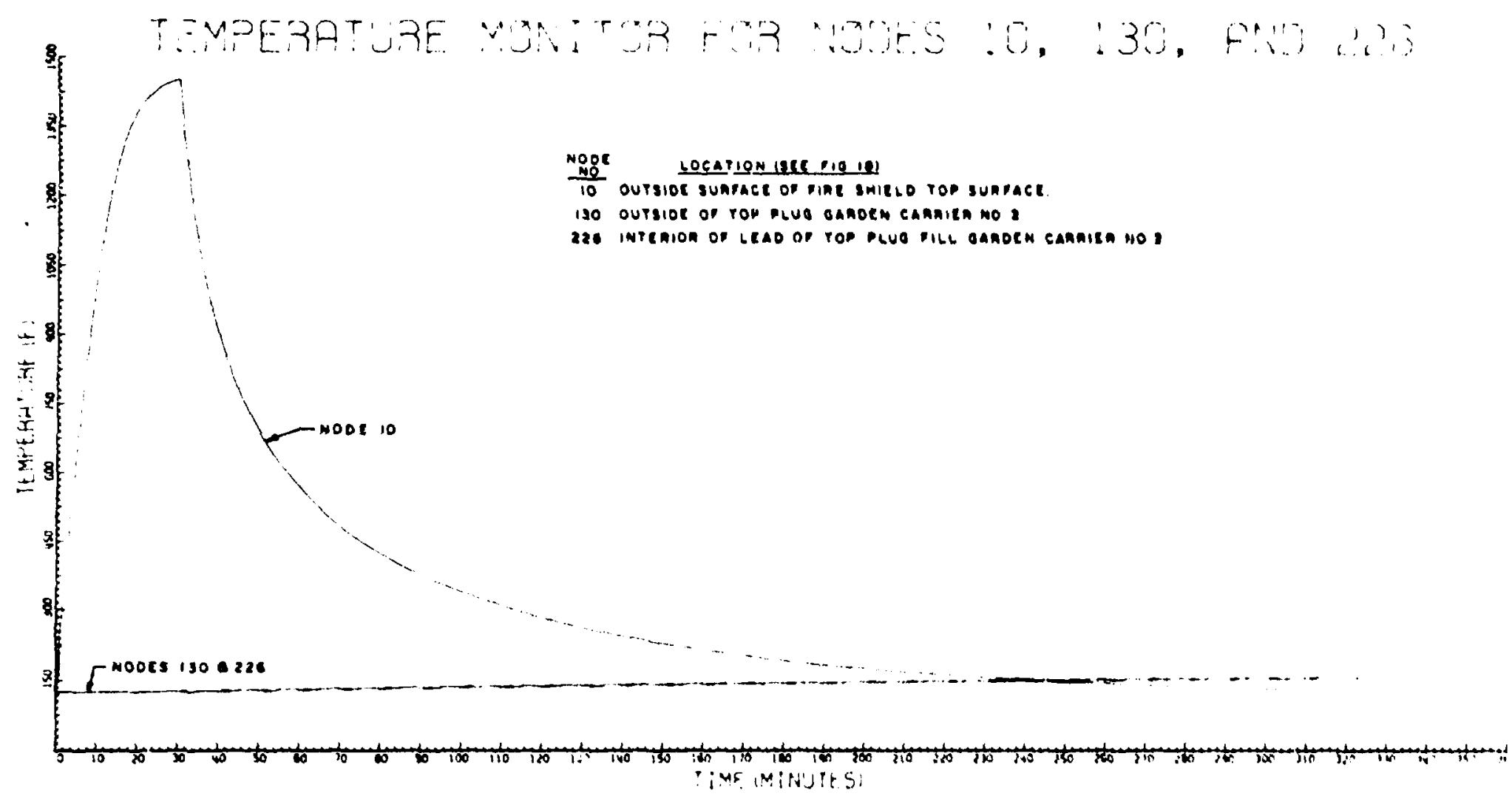

F1g. 23. Temperatures at various points at the top of the Garden Carrier No. 2 shipplng assembly as determined during and after the thermal accident conditions. 


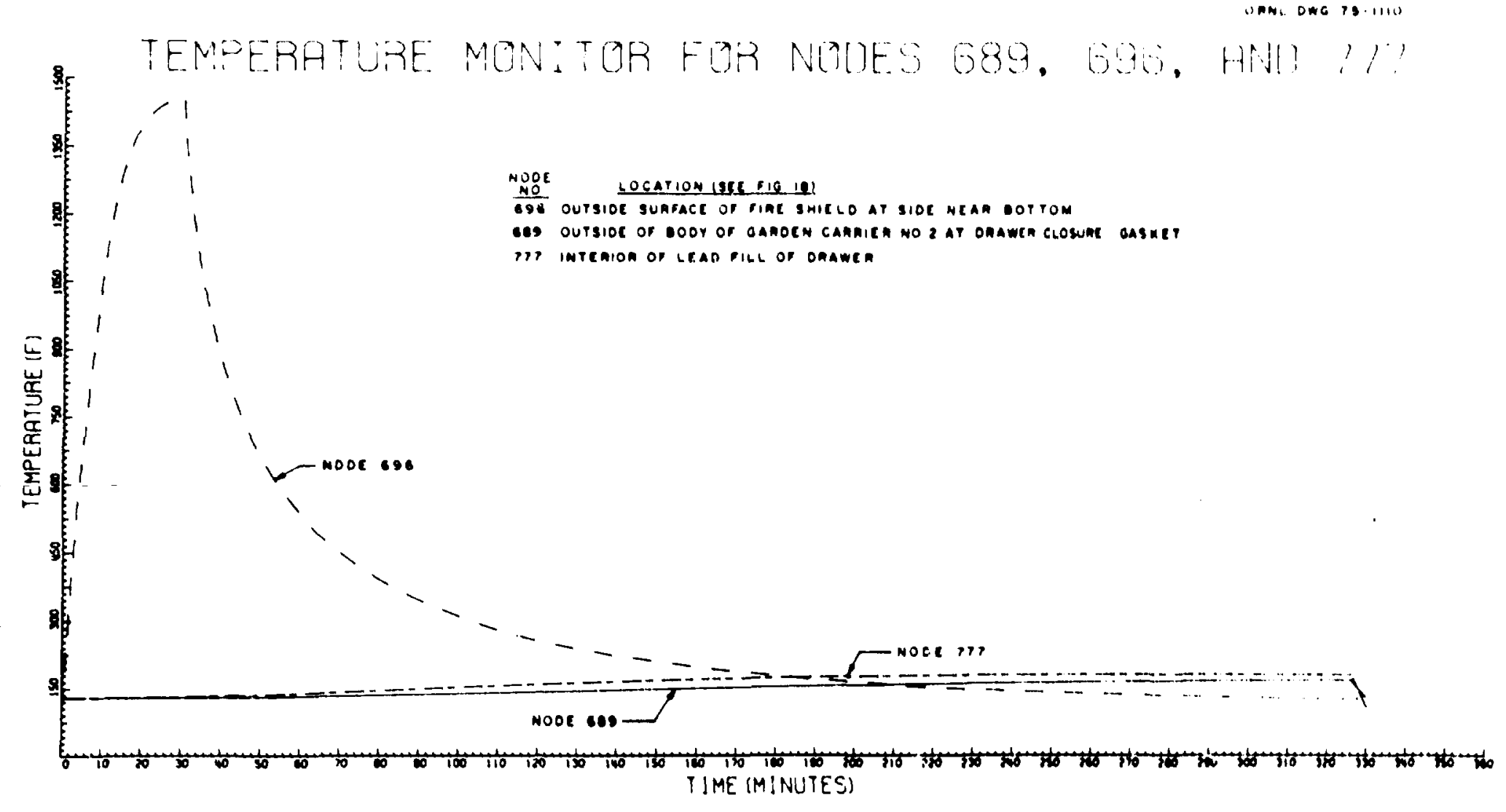

Fig. 24. Temperatures at varlous points near the bottom side of the Garden Carrier No. 2 shipping assembly as determined during and after the thermal accident conditions. 
Table +1 . Pressures in internal air gaps for 100-H load

\begin{tabular}{|c|c|c|c|}
\hline \multirow[b]{2}{*}{ Region ${ }^{2}$} & \multirow[b]{2}{*}{ Description } & \multicolumn{2}{|c|}{$1475^{\circ} \mathrm{F}$ Fire } \\
\hline & & $\begin{array}{c}\mathbf{T}_{\text {alr }} \\
\left.\mathbf{}^{\circ} \mathbf{F}\right) \\
\end{array}$ & $\begin{array}{l}\text { Pressure } \\
\text { (psig) }\end{array}$ \\
\hline 12 & $\begin{array}{l}\text { Between top of inner container and bottom } \\
\text { of top plug }\end{array}$ & 165 & 4.58 \\
\hline 19 & $\begin{array}{l}\text { Between side of inner container and side } \\
\text { of inner cavity }\end{array}$ & 184 & 5.11 \\
\hline 30 & Between dravers at center & 190 & 5.27 \\
\hline 34 & Between drawers and drawer closure plate & 187 & 5.19 \\
\hline 36 & Between draver and bottom closure place & 192 & 5.33 \\
\hline 43 & Between side of base plate and fire shield & 184 & 5.11 \\
\hline 47 & $\begin{array}{l}\text { Between side of carrier and inner shell of } \\
\text { fire shield }\end{array}$ & 160 & 4.44 \\
\hline 52 & $\begin{array}{l}\text { Between top of carrier and inner shell of } \\
\text { fire shield }\end{array}$ & 162 & 4.49 \\
\hline 56 & Inside Inner container & 188 & 5.22 \\
\hline
\end{tabular}




\subsection{Containment Reyuirements for Normal Conditions of Transpon}

The inner containers will withstand pressures and temreratures in excess of those encountered in normal transport. Section 5.3 indicates that the maximum normal operating pressure encountered in normal transport will ie 5.6 psig at $202^{\circ} \mathrm{F}$ (sec Table 8). Cinder these cor.ditions. no release of radioactive material. loss of coolant (air). or contamination of coolant should occur.

\subsection{Containment Requirements During 'he Hypotheticai Accident}

The inner containers will withstand pressures and temperatures in excess of those encountered in the hypothetical acrident. It is shown in Sect. 8 that the maximum operating presstire during the hypothetical accident conditions will be 10.5 psig at $230^{\circ} \mathrm{F}$.

\section{INNER CONTAINERS}

A 2R pipe cap container and a screwed-top inner container (Fig. 25) have been approved for use with the Garden Carrier No. 2. These containers may be used for solids shipments.

Fabrication of these containers will be in accordance with ORNI. Quality Assurance Procedures for Quality Level III fabrication. Applicable approved OR.NL procedures will be used for welding. All weiss will be appropriately inspected in accordance with approved OR.VL. weld inspection procedures. Containers shall be leak tested using bubble techniques or helium leak-detection methods.

\subsection{Screw-Top Inner Container}

The screw-top inner contairer, shown in Fig. 25 has a maximum length of 23-5 8 in. The container needs to be made only as long as necessary to contain the material inside it. The neoprene "O"-ring gaskets will not be damaged by the therma! test (see Sect. 6.3.4).

Since the nature of the radioactive contents of the inner container in the cask are either solids or liquids, the inner container vessel pressure that will develop due to the expansion of the contained gases, plus the vapor pressure of the liquid (water) at the maximum temperature. will be assumed to be "the most severe anticipated case." A pressure of 10.5 psig will result [see Eq. (120)]. It is demonstrated helow that the screw-top inner container meets the requirements of Section VIII of the ASME Boiler and Pressure Vessel Code." It is demonstrated that the screw top inner container is capable of a maximum intemal pressure of 59 psig. 
ORNL DWG 75-4899

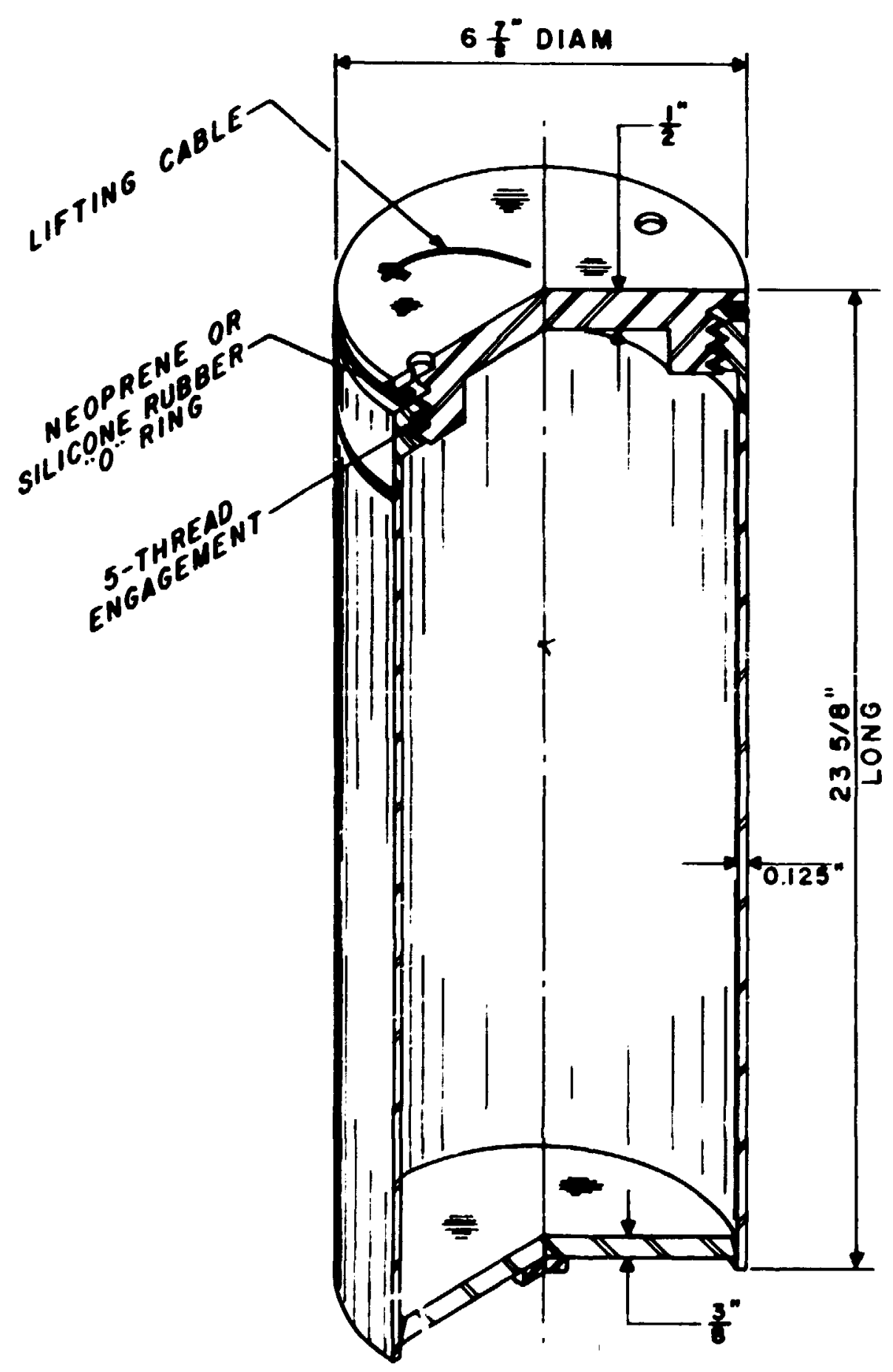

Fig. 25. Screwed-top inner container. 


\subsubsection{Inner contciner wall thickness}

From Paragraph CG-27." the minimum wall thickness for the eylindrical portion of the inner container is determines by

$$
t=\operatorname{Pr} S E-0.6 P \text {. }
$$

where

$$
\begin{aligned}
& \mathbf{P}=\text { pressure. } 10.5 \text { psig. } \\
& \mathbf{r}=\text { inside radius of shell. } 3.3125 \mathrm{in.} . \\
& \mathbf{S}=\text { design stress. } 7800 \text { psi (Table } \mathrm{U} \text { HA-23)." } \\
& \mathrm{E}=\text { joint efficiency. } 1.0 .
\end{aligned}
$$

The minimum allowable wall thickness

$$
t=(10.5 \times 3.3125)[7800(1.0)-0.6(10.5)]=0.004 \text { in. }
$$

The wall thickness of the cylindrical portion of the screw-top inner container is 0.125 in. which cxcecds the requircments of the ASME Code.

Substituting the wall thickness $(0.125$ in.) in the above equation (No. 120) and solving for P. the pressure for which the inner container wall is capable of withstanding is 288 psig.

\subsubsection{Inner consainer hortom flat head thickness}

From Paragraph UG-34." the minimum thickness of the bottom flat head of the inner container is determine's by

$$
t=d(C P S)^{12}
$$

where

$$
\begin{aligned}
& d=\text { diameter inside, } 6.625 \text { in.. } \\
& C=\text { design constant, } 0.3 \mathrm{in} ., \\
& P=\text { pressure, } 10.5 \text { psig. } \\
& S=\text { design stress, } 7800 \text { psi (see Table UHA-23)," }
\end{aligned}
$$




$$
1=0.625(0.340 .57800)^{12}-0.133 \text { in. }
$$

The bottom flat head of the screw-top inner container is 38 in. thick and meets the requirements of the ASME Code.

Substituting the bottom nathead thickness $(38$ in.) in the above equation (121) and solving for $P$. the pressure which the inner container bottom is capable of withstanding is 83 psig.

\subsubsection{Inner container top head thickness}

From Paragraph 1:G-34." the minimum thickness of the screw top head of the inr..r ntainer is determined by

$$
t=d(C P S)^{1}
$$

where

$$
\begin{aligned}
& d=\text { diametet inside. } 6.625 \text { in.. } \\
& C=\text { design constant, } 0.75 \\
& P=\text { pressure. } 10.5 \text { psig. } \\
& S=\text { desigr stress. } 7800 \text { psi (see Table UHA-23), } \\
& Q=6.625\left[(0.75 \times(10.5) \cdot 7800]^{\prime 2}=0.211\right. \text { in. }
\end{aligned}
$$

The screw-top head of the screw-top inner container is 12 in. thick and exceeds the requirements of the ASME Code.

Substituting the top head thickness (1 2 in.) in the above equation (122) and solving for $P$, the pressure which the inner container top is capable of withstanding is 59 psig.

\subsection{Thirty-foot Free-fall Test}

Two containers of the same type as described above were fabricated and tested ${ }^{\text {th }}$ by the 30-ft free drop on a comer and flat on the bottom. No damage was sustained by either the container or the containment; therefore. no damage should be expected for these inner containers.

Liquid-filled polyethylene bottles inside these containers have survived the $30-\mathrm{ft}$ drop without loss of contents. 


\section{CRIIICAIIIY}

The analysis for the single container given below is shown to be adeyuate for an infinite array of similar containers.

\section{I Evaluaion of a Single Package}

A criticality analysis has been made (see Nuclear Safety Review 776 in Appendix B).

Since the yuantity of fissile isotopes carried is below all minimum critical masses for these isotopes under optimum moderation and reflection, and since the cask effectively isolates the contents from neutron interaction with packages of similar design. unlimited numbers could be stacked with no criticality problem occurrir.g. Thus the package is adequate for Fissile Class I shipments.

\section{SHIELDING EVALLATION}

\subsection{Discussion and Results}

The cavity in the Garden Carrier No. 2 is surrounded by a 0.375 -in.-thick stainless steel inner shell and a 0.50 -in.-thick outer stainless steel shell. The shielding cavity between the two is filled with lead that is $8-116$ in. thick. In addition. the cask contents are limited to a source strength that will not exceed the allowable radiation dove limits of the DOT regulations."

The conditions of normal iransport and the hypnthetical accident produce minor deformation of the fire shield and essentially no loss of shielding (see Sects. 5 and 6). Any slight increase in the dose rate will be below the permissible limits.

\section{QUAI.ITY ASSURANCE}

\section{I.I Fabrication. Inspection. and Acceptance Tests}

The fabrication of this cask was performed in the Oak Ridge National Laboratory Shops in accordance with normal shop fabrication procedures. Material was specified on the original drawings as "304L. SST." Material was withdrawn from stores stock. The cask was inspected by ORNI. Shop Inspection pers,nnel for conformance to the drawings, quality, of workmanship. and compliance with welding requirements when fabricated. In the opinion of the inspecting personnel. the weldments were made in accordance with the drawings and

specifications. This is further supported by the fact that the cask has operated for six years without failures or loss of effectiveness. An inspection of the cask was made to verify its integri'y (see Appendix E). The routine operating inspection procedures specify periodic weld 
inspections to verify weld integrity.

\section{II.2 Operating Procedures and Routine Inspections}

The Chemical Technology Division has established operating and routine inspection procedures and standard checklists to ensure that all shipments are safe and that they comply with ERDA regulations. as well as all ORNL procedures and regulations. A copy of typical procedures and checklists are presented in Appendir :: The completed records are kept in Bdg. 4500N, Room A-16.

\subsection{Periodic Maintenance and Inspections}

Biennial inspections and inspections before each shipment will be made as outlined in Appendix F. Maintenance will be performed when inspections indicate damage. The completed records are kept in Bldg. 4500N. Room A-16. 
12. APPENDIXES

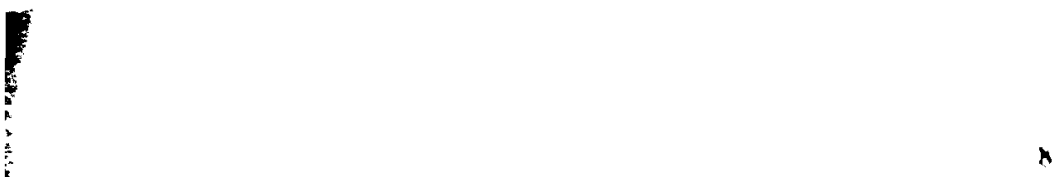




\subsection{Appendix A - Draw1ngs}

Page Mo.

Garden Carrier Ho. 2 Asseably

14-11332-54-010-E-4

Garden Carrier No. 2 Detall Sheet No. 1 84 H-11332-E4-011-E-3

Garden Carrier No. 2 Detall Sheet No. 2

- 11332-EY-012-E-2

Garden Carrier No. 2 Detall Sheet No. 3 86 H-11332-E4-013-E-O

Garden Carxier No. 2 Detall Sheet No. 4 87 H-11332-EH-014-E-2

Garden Carrier No. 2 Detall Sheet No. 5 88 H-11332-DM-015-E-1

Garden Carrier No. 2 Detall Sheet No. 6 89 4-11332-E4-016-E-0

Garden Carrier No. 2 Detall Sheet No. 7 M-11332-EH-017-D-0

Garden Carrier No. 2 Assembly and Skid W-11332-EA-018-E-4

Garden Carrier No. 2 Screwed Top Inner Container 4-11332-EM-019-D-D

$4-11332-\mathrm{EA}-020-\mathrm{C}-4$

H-12124-CB-043-D-?

Garden Carrier Ho. 2

M-12166-CD-037-D-2

Garden Carrier No. 2 Fire Shleld Assembly and Detalls y-12166-CD-043-E-I 
BLANK PAGE 


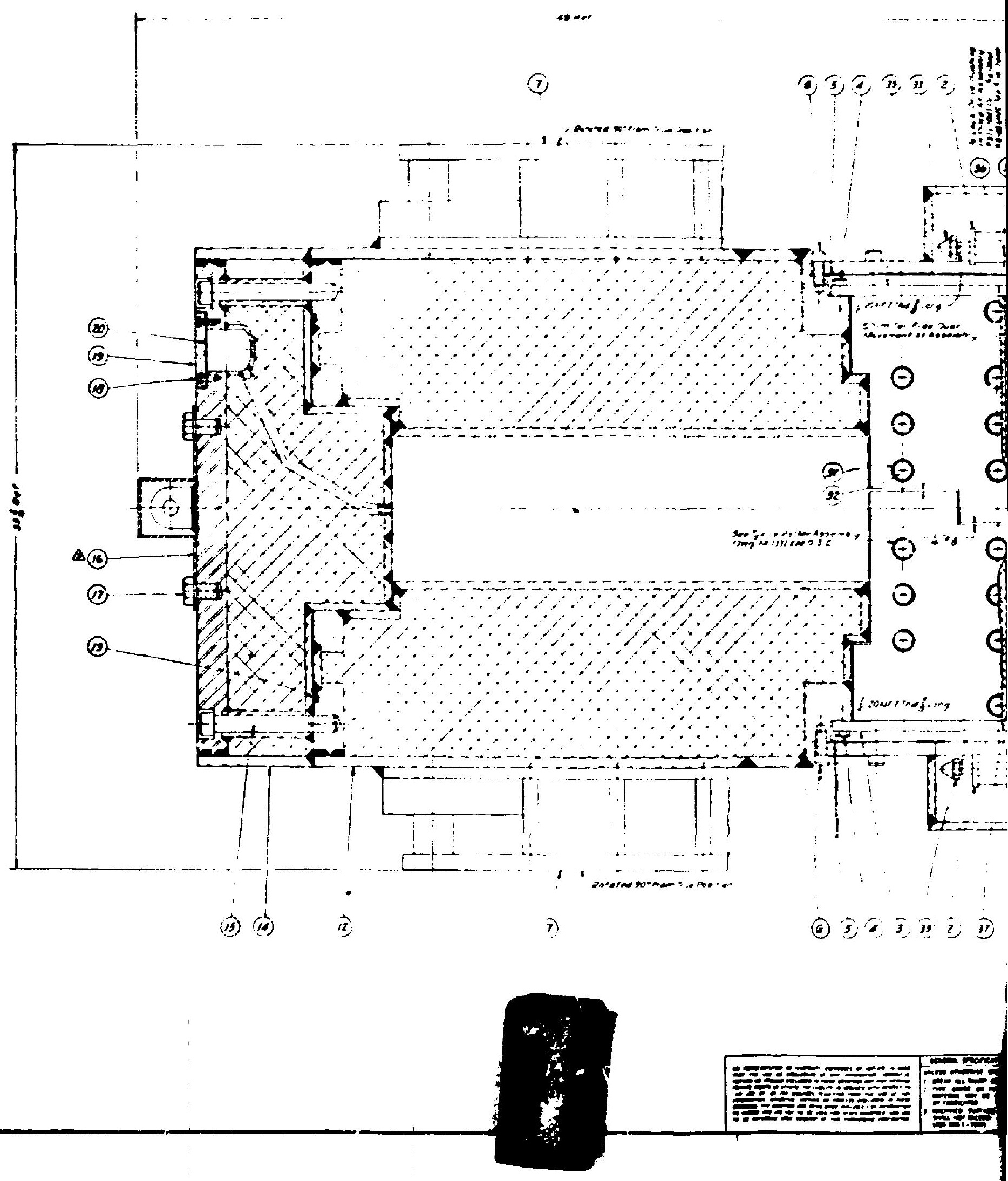




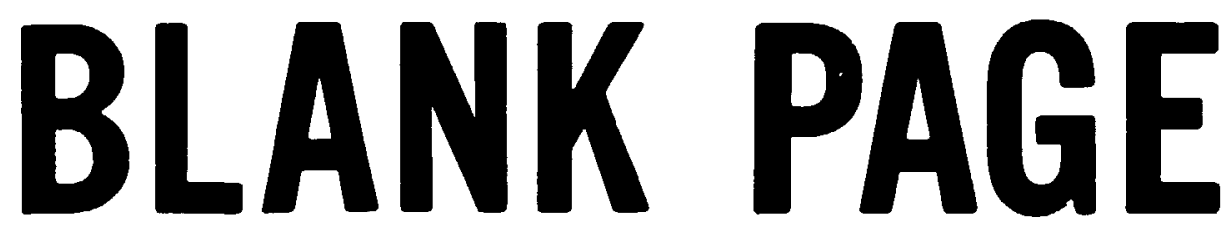


c

(7)

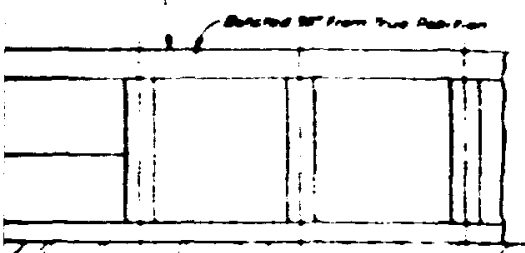

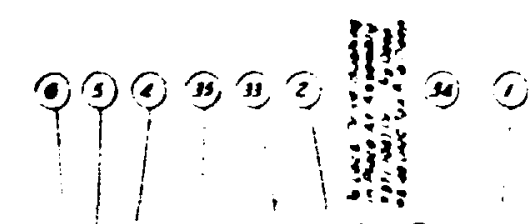

(3) (II)

值

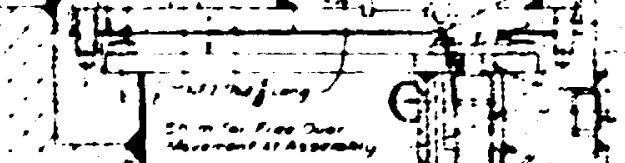

$8 \times 48$
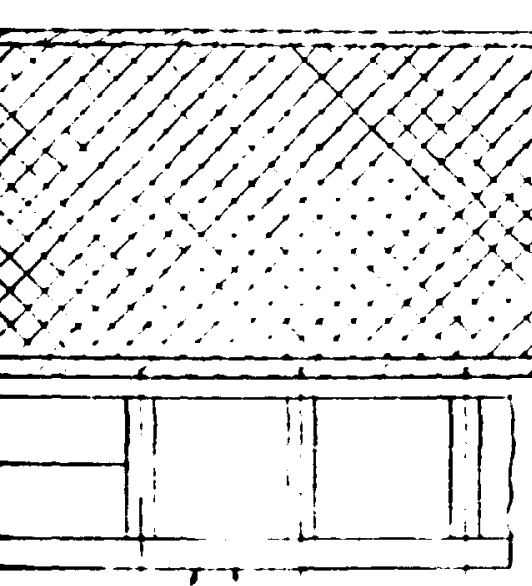

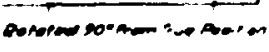

(7)

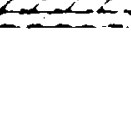


BLANK PAGE

$=$ 


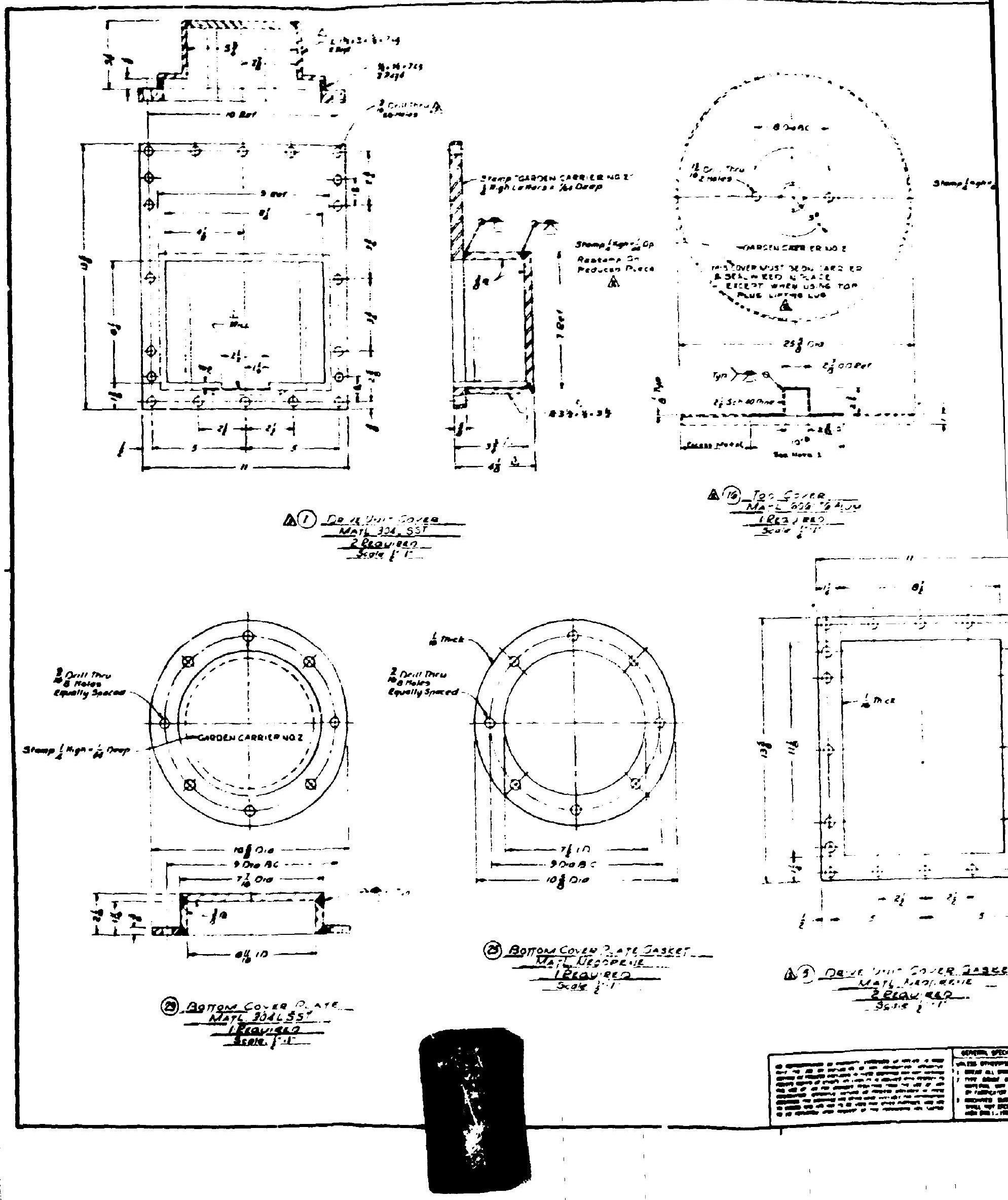




\section{BLANK PAGE}

a 


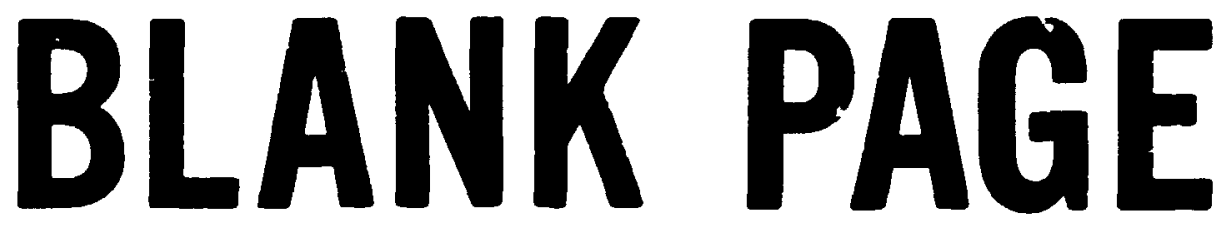




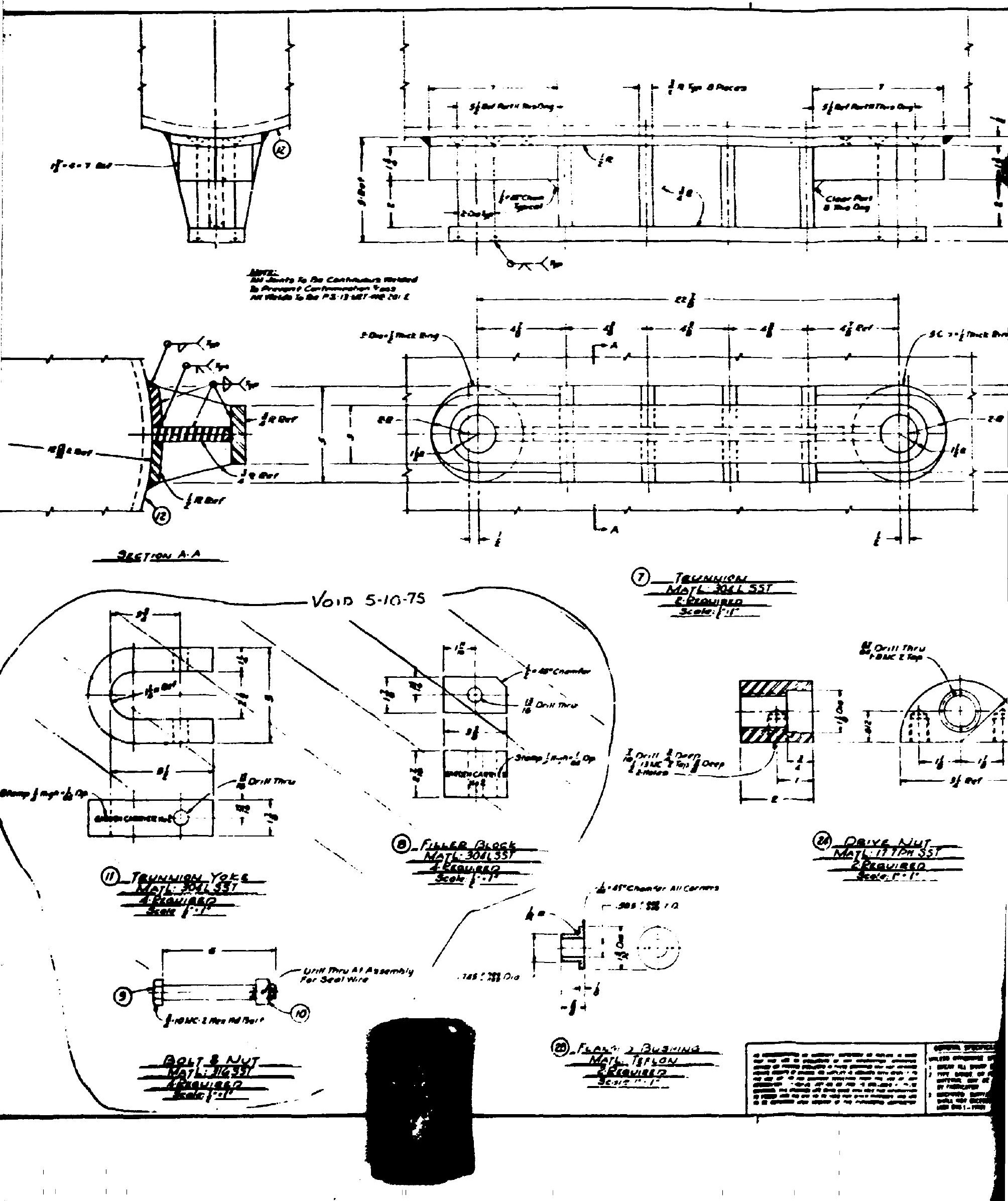




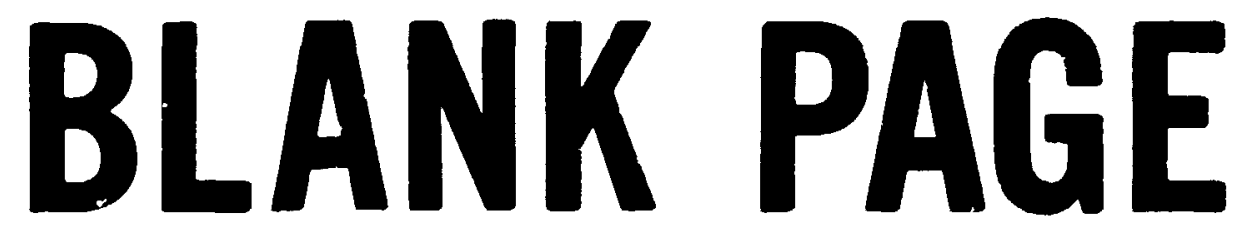




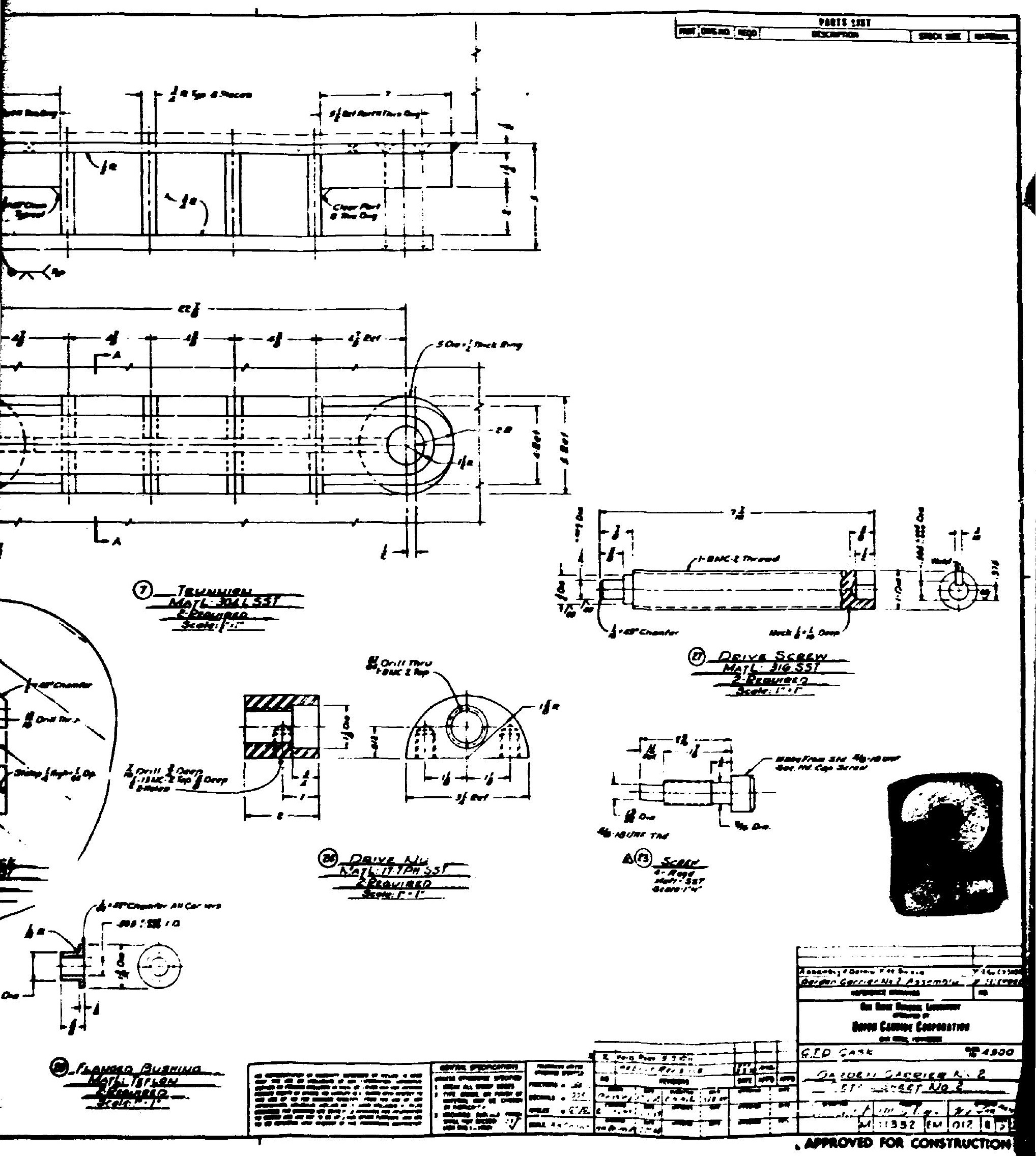


BLANK PAGE 

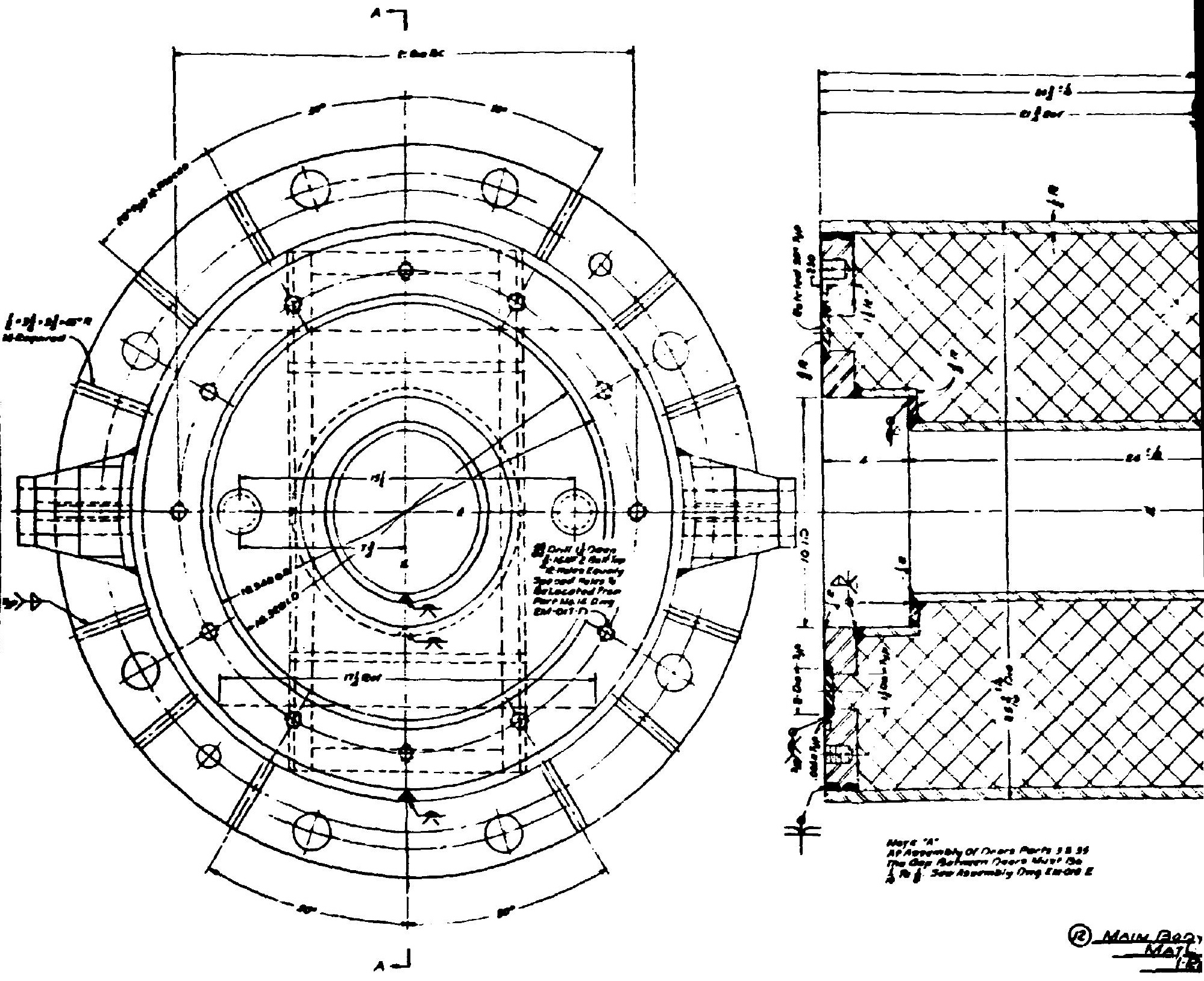

Ior-kene
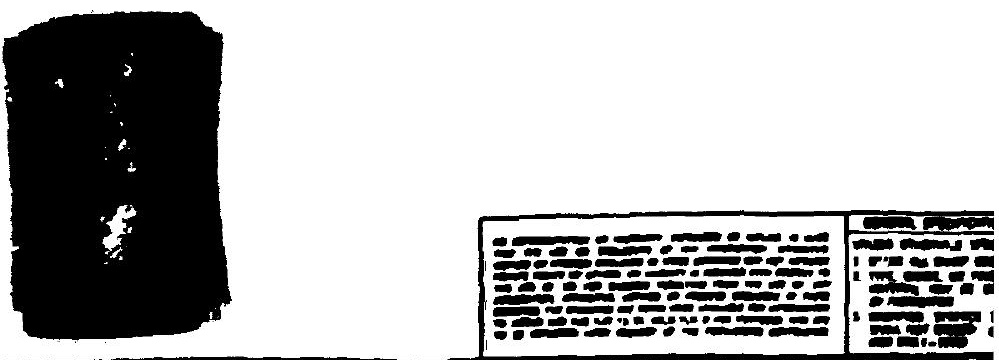


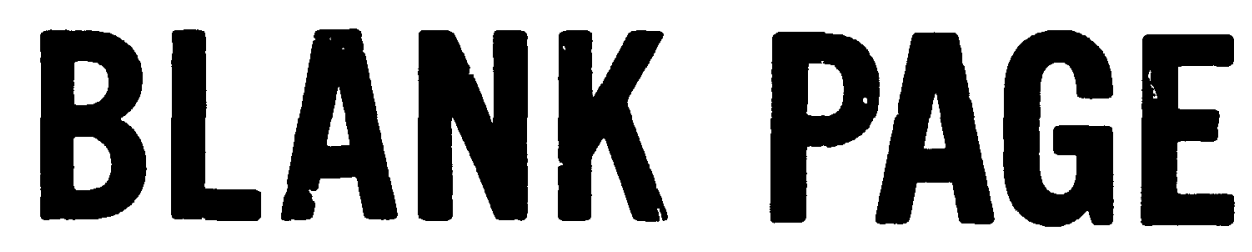




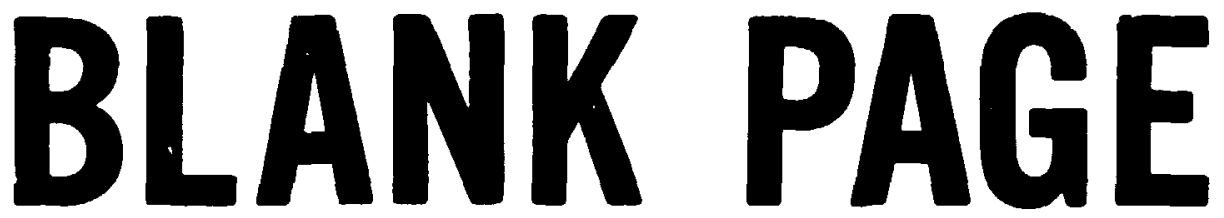




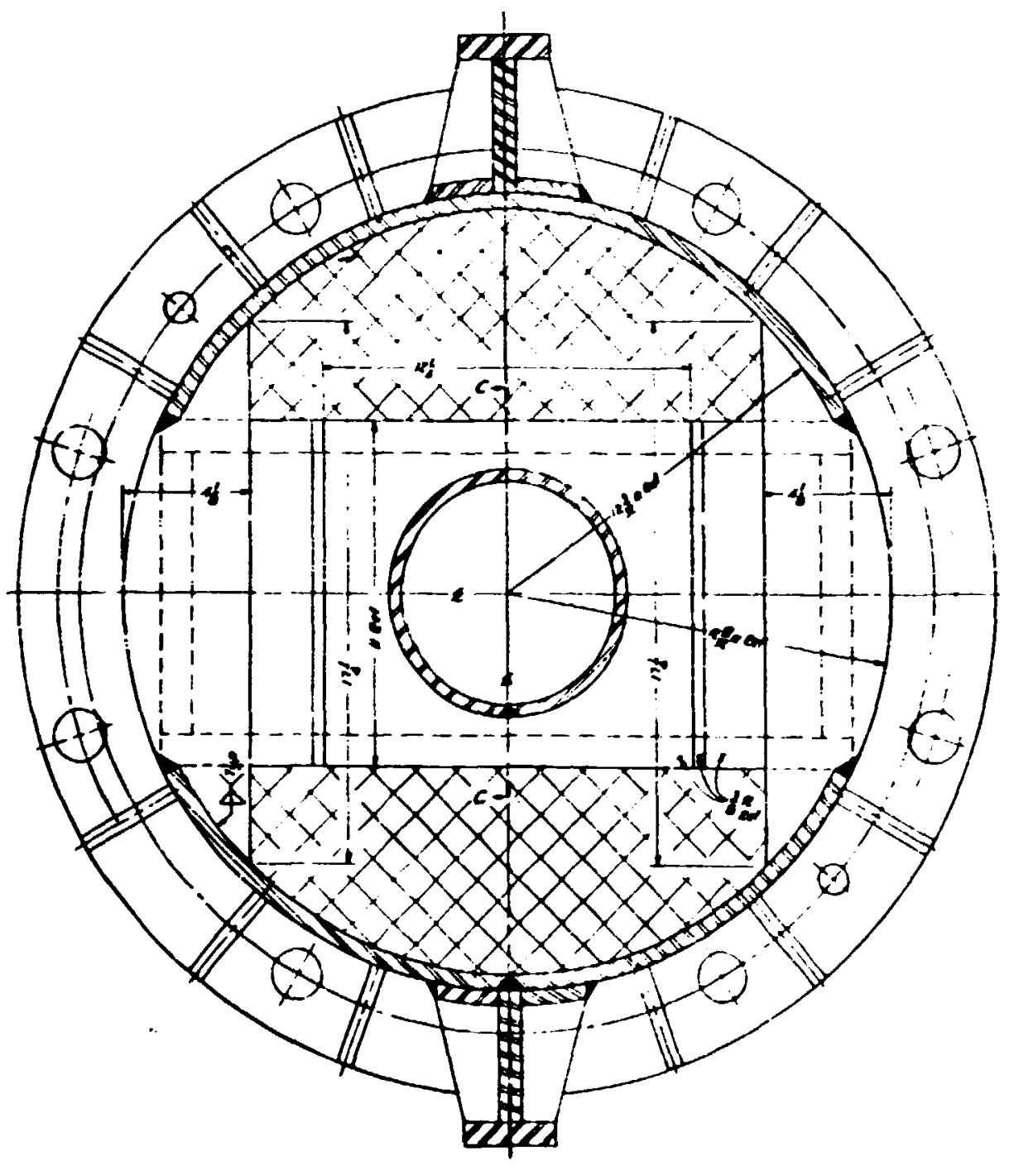

Strien $A B$
(2)

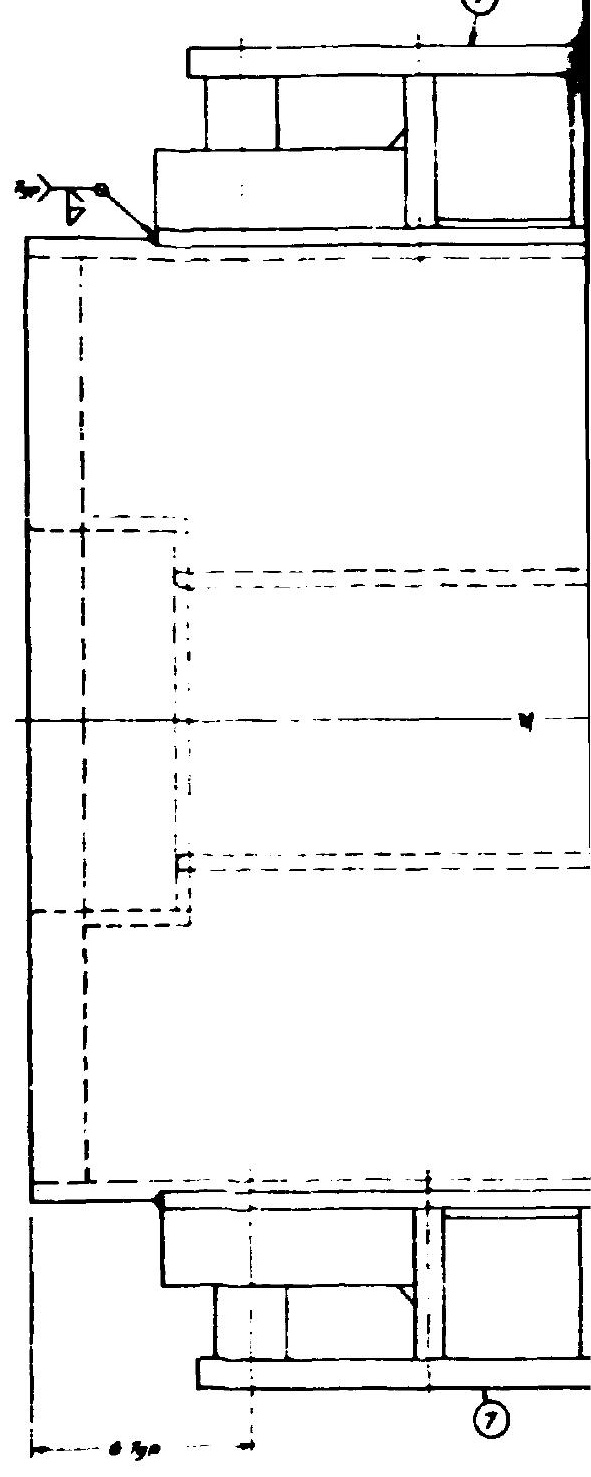

둥ㅅㅅ
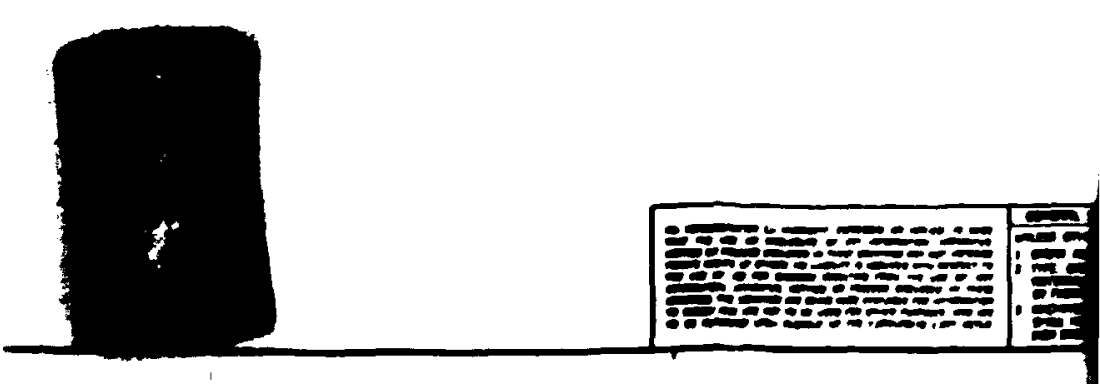


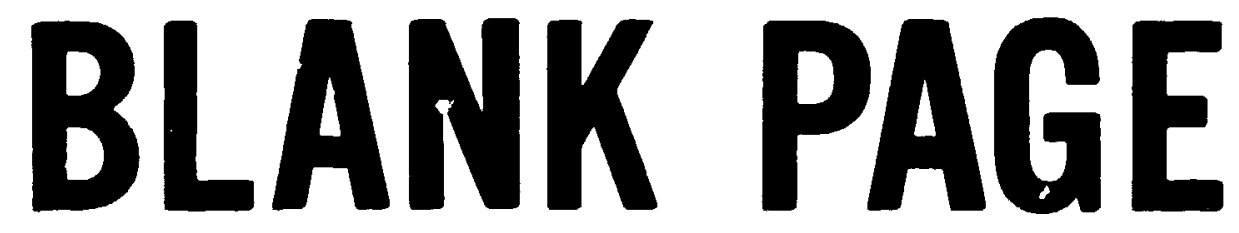




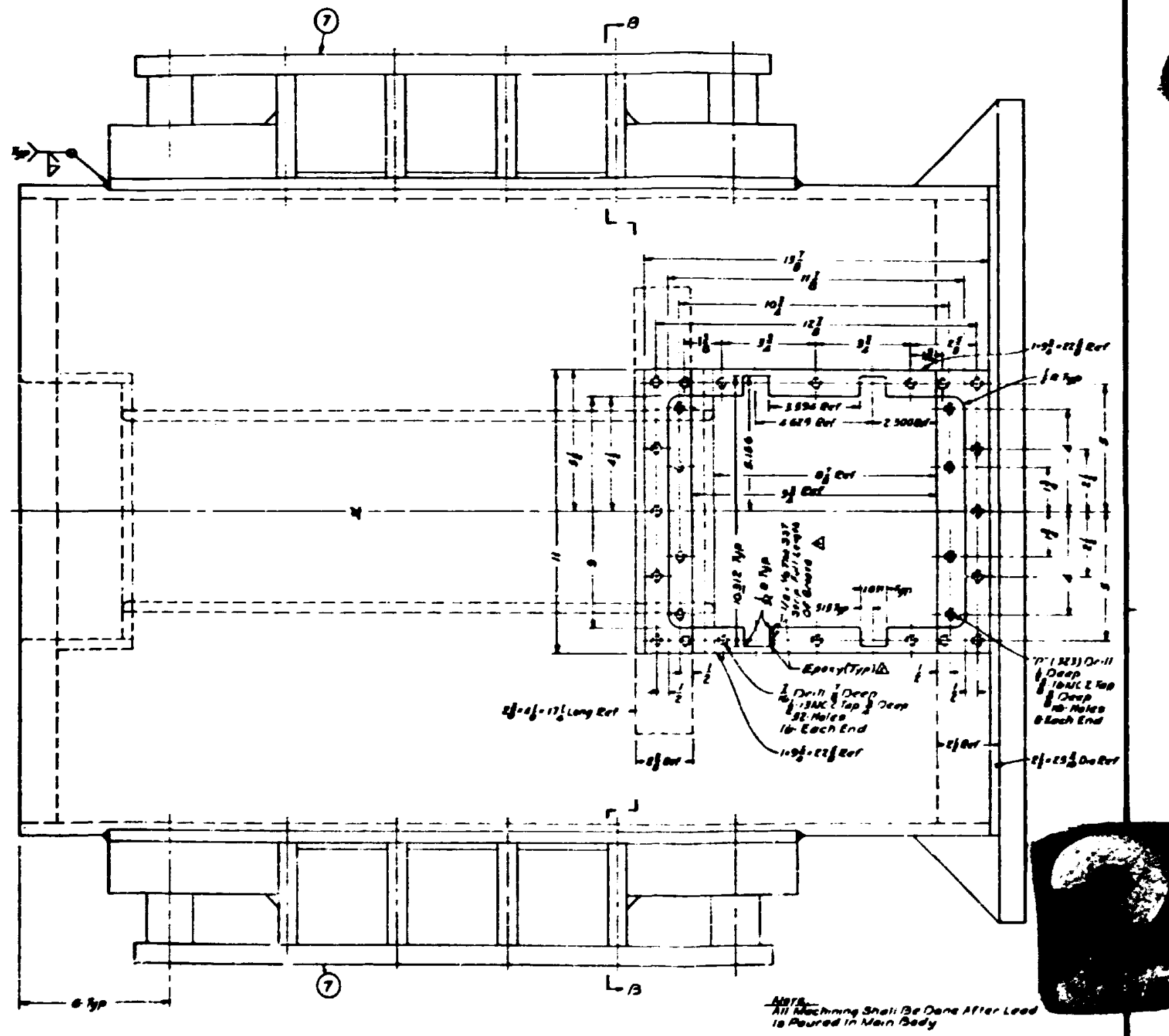

-(B) Man Bopr. Feent Vien

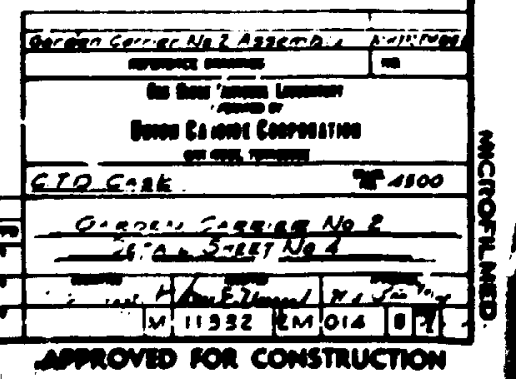


BLANK PAGE 

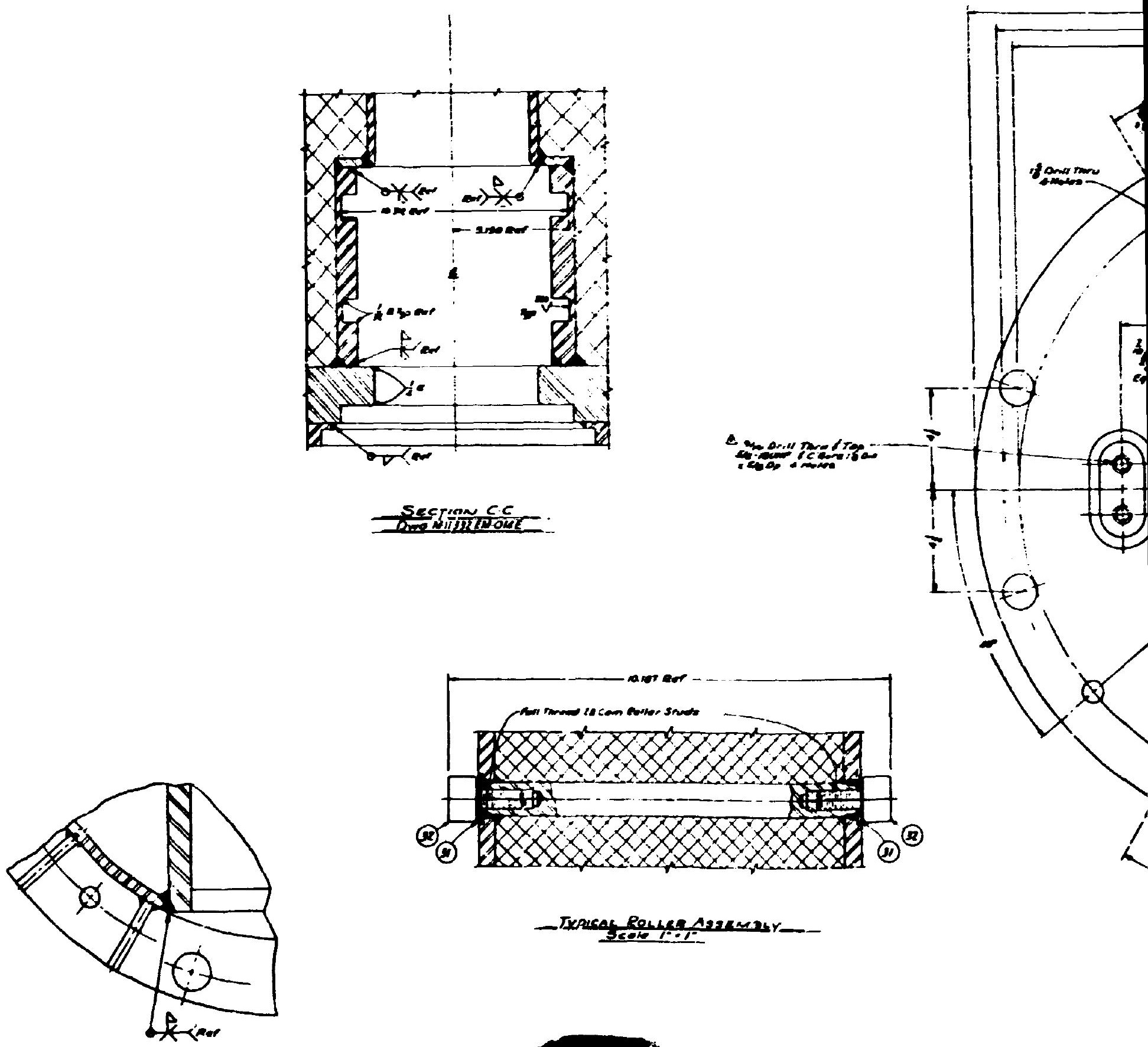

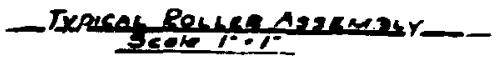

Goertecure Deraun
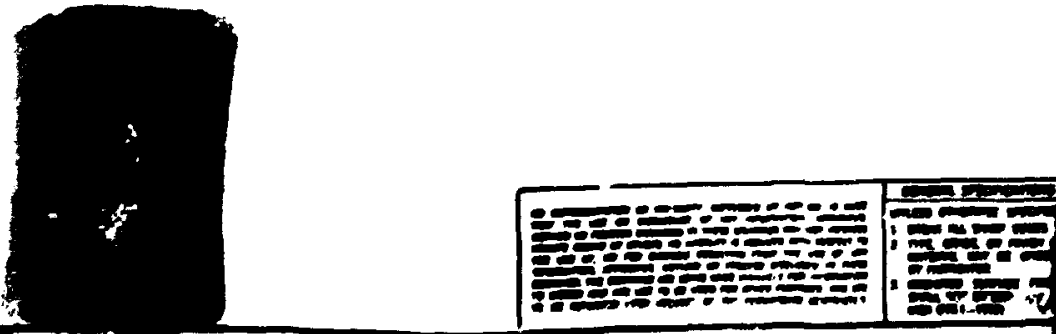


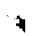

-

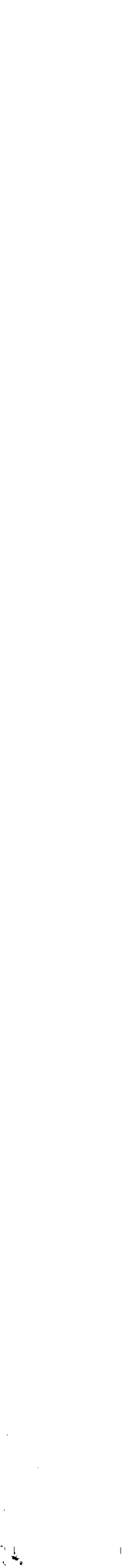

\section{BLANK PAGE

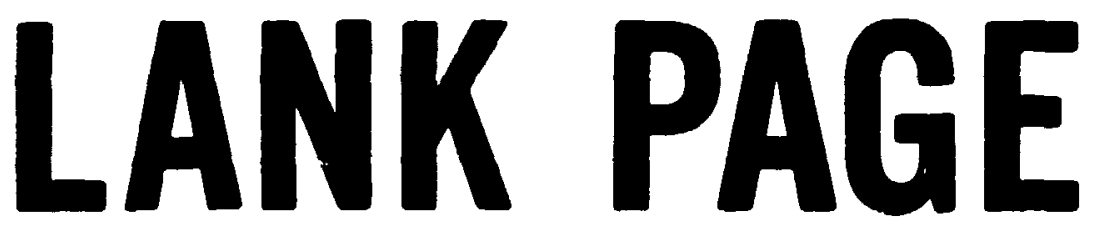

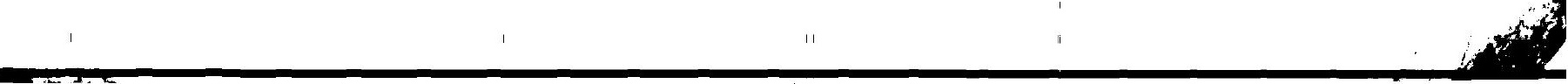




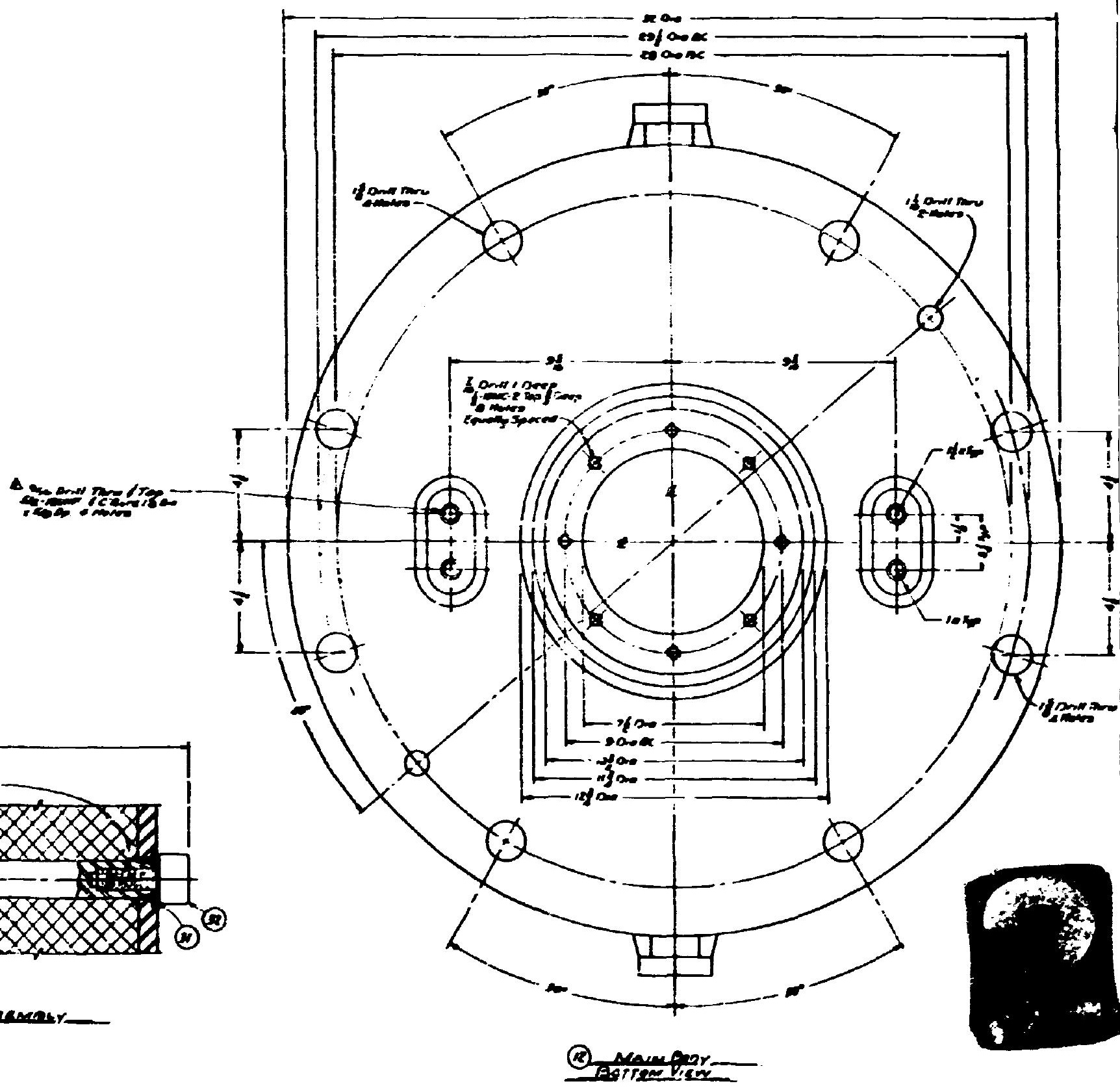

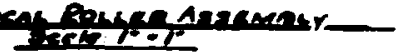




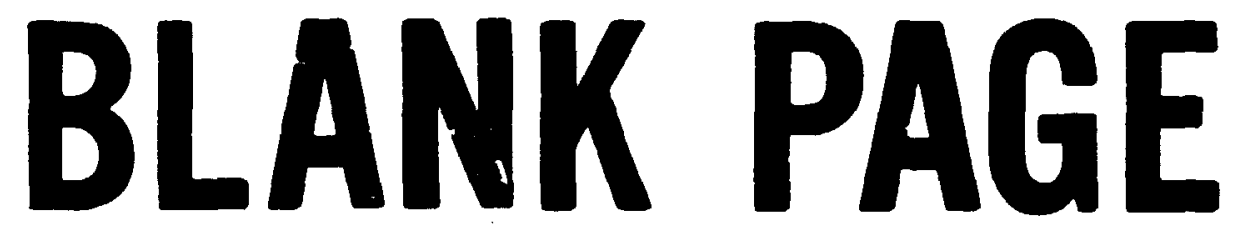


$x^{2}-7-1-$

\section{BLANK PAGE}
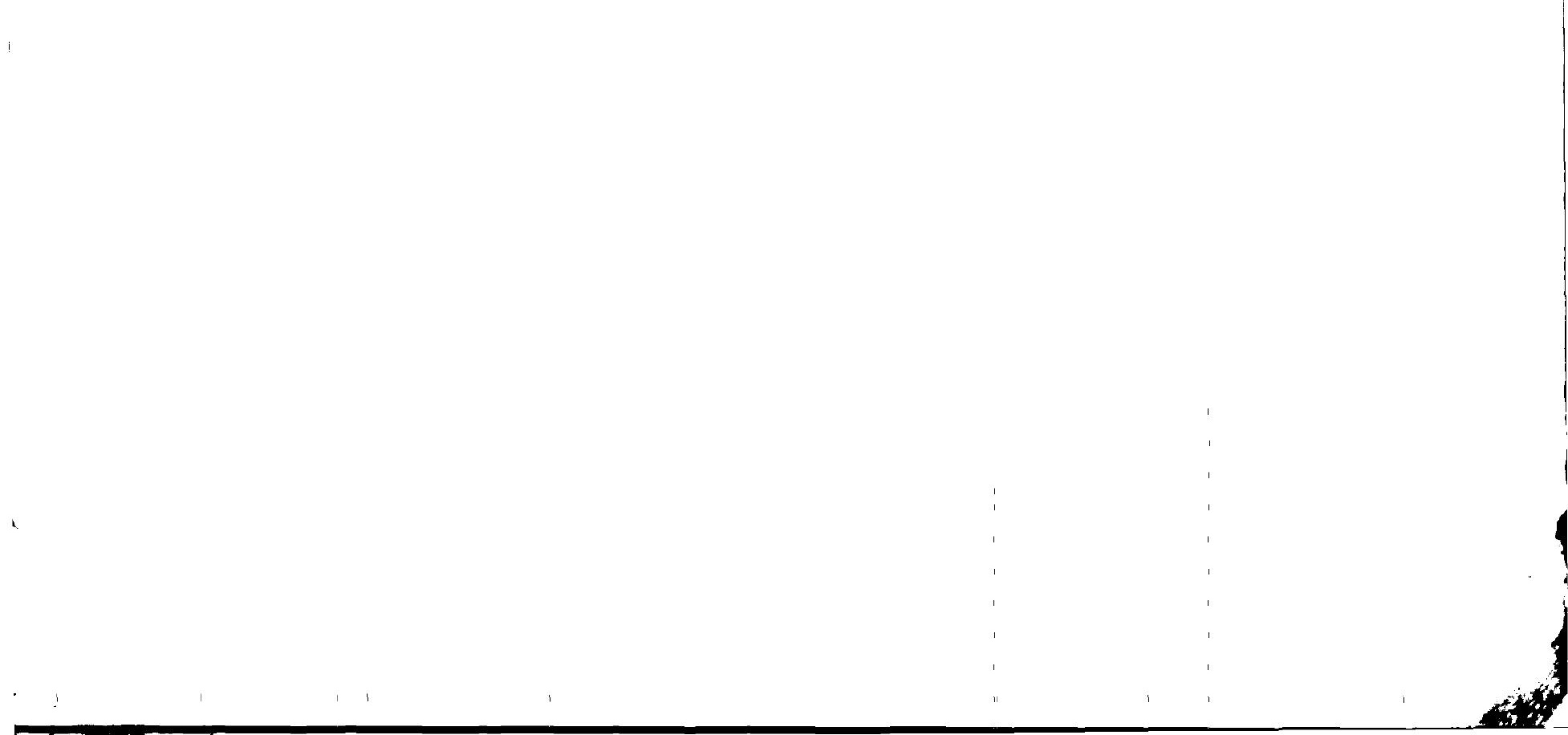


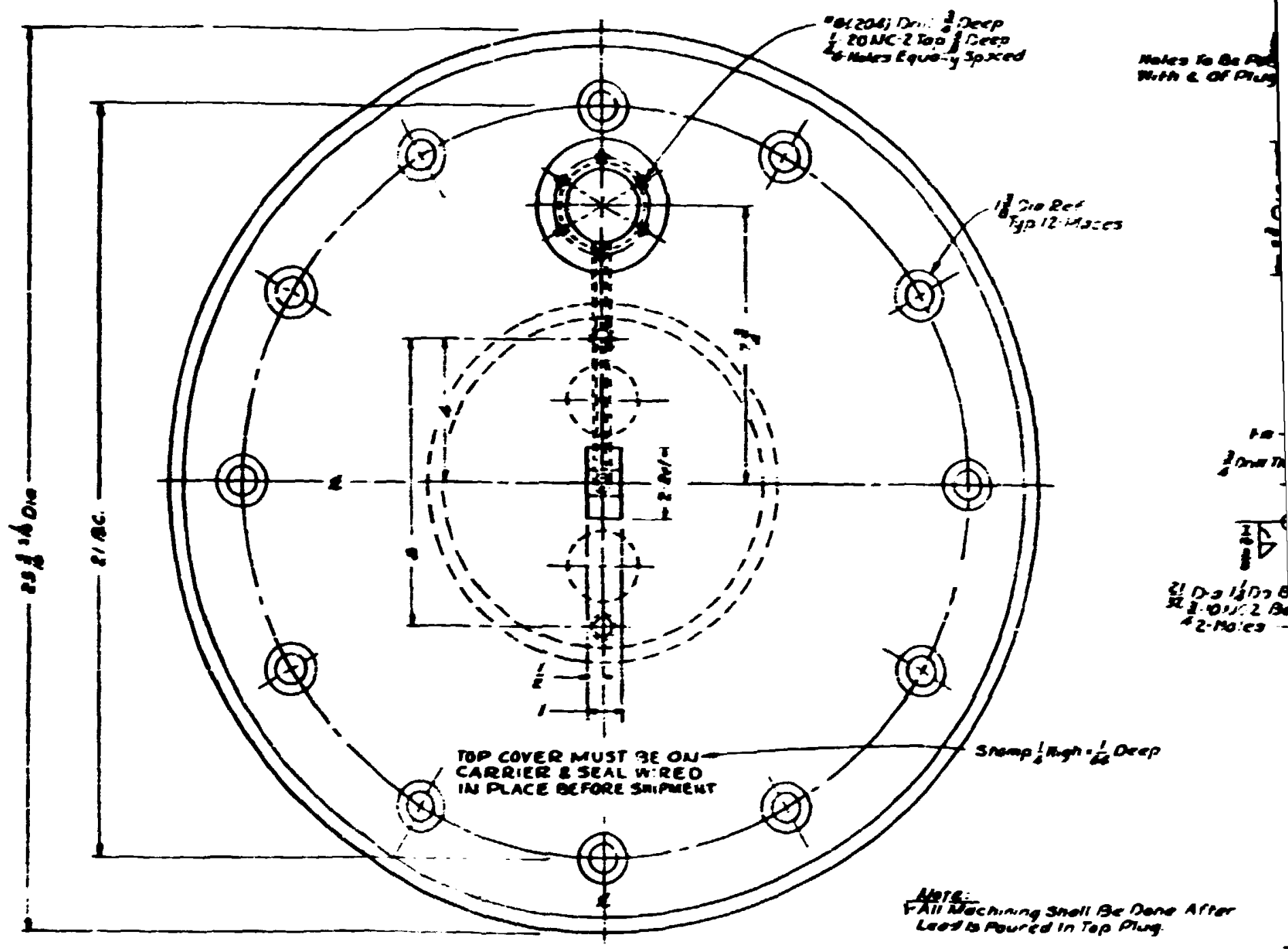

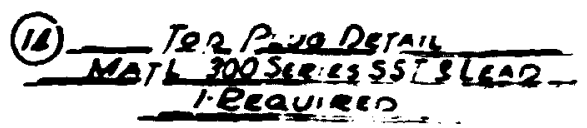
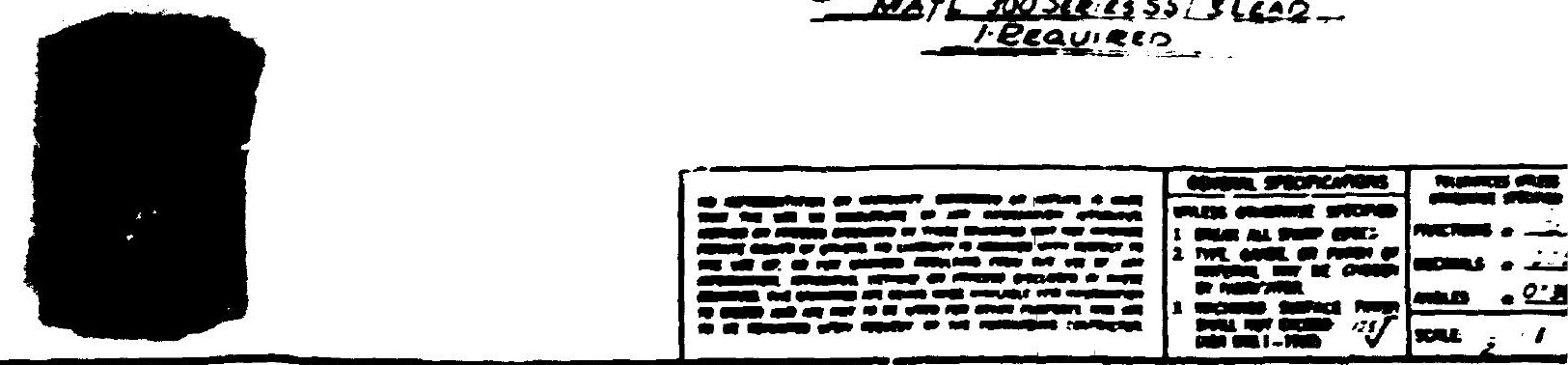
BLANK PAGE 
BLANK PAGE

$\because$ 
$\Delta$

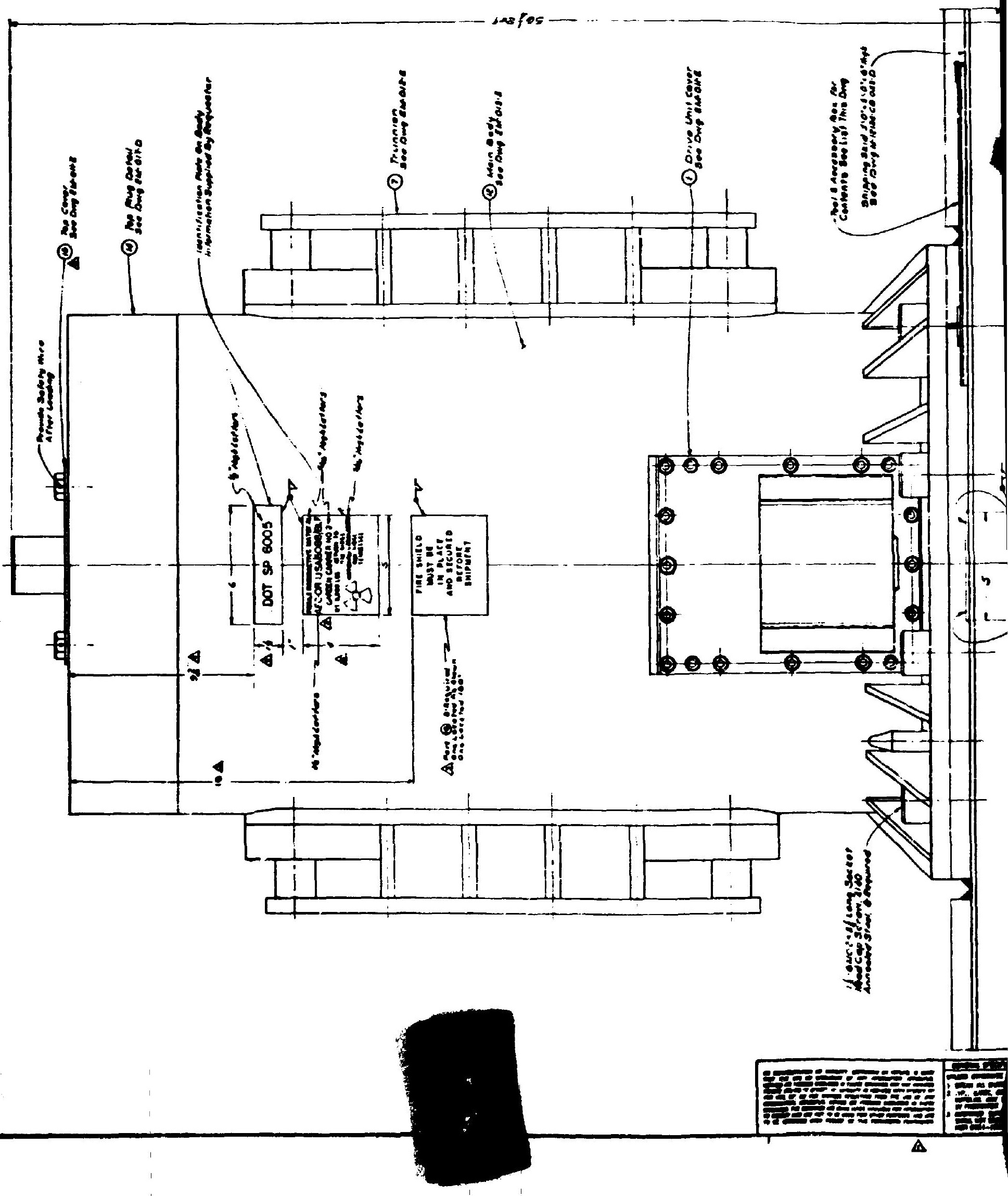


BLANK PAGE 



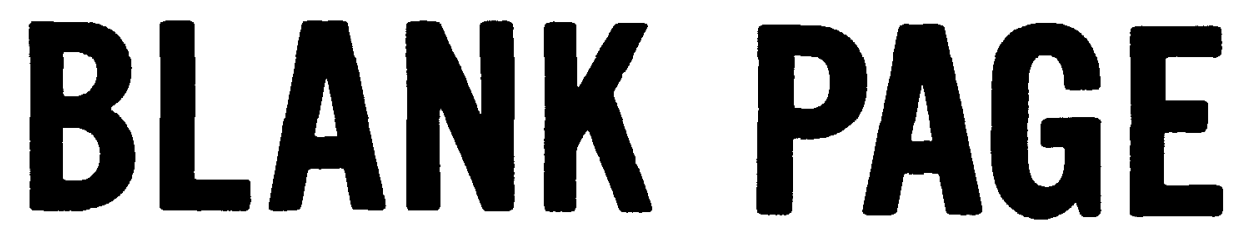




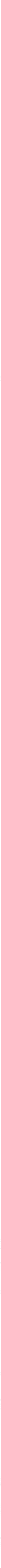



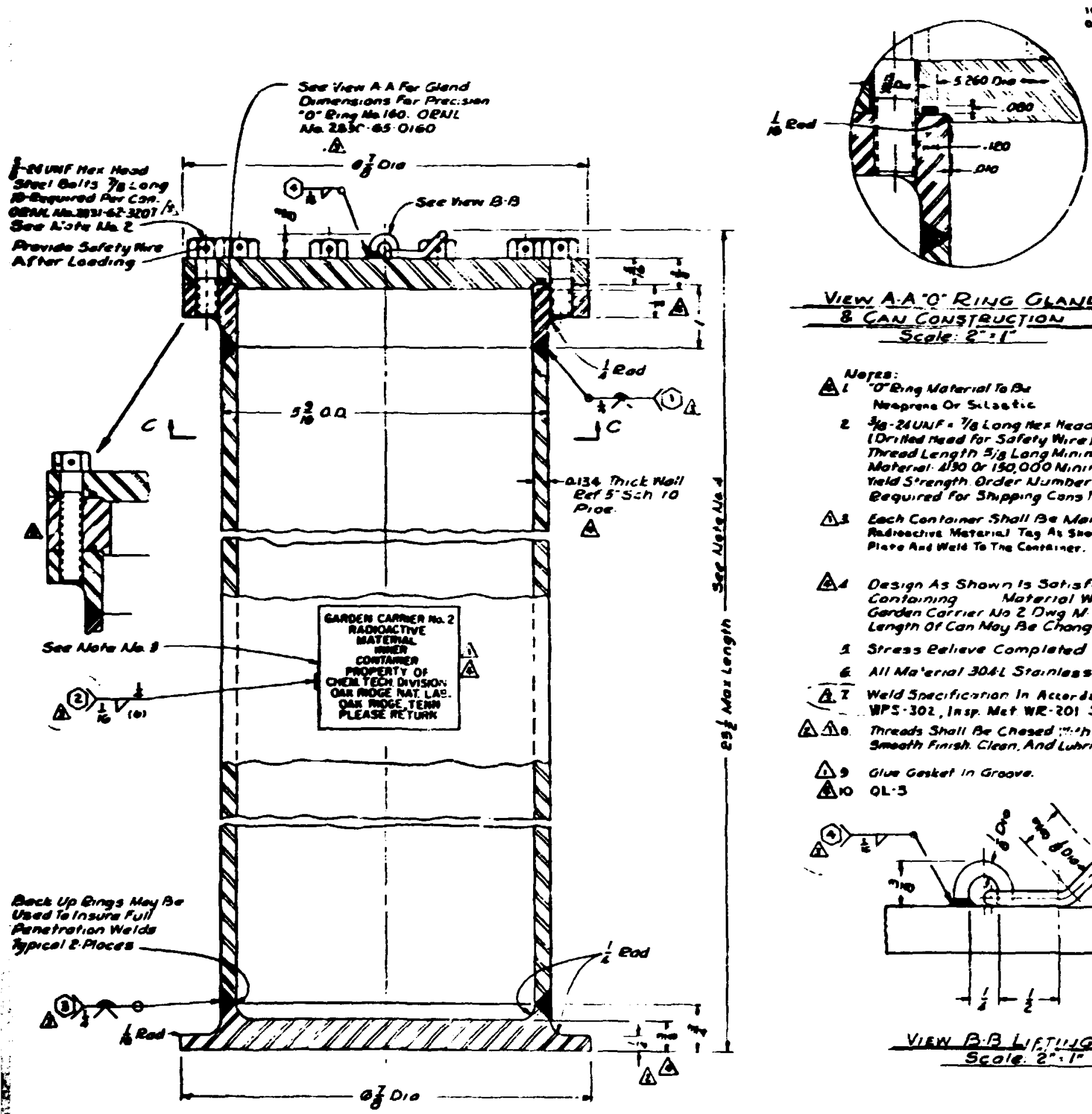

This

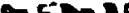

Vien A.A.O"RING GLANO

I CAN Consteuction Seple: $e^{2}: T^{2}$

Al Nore: Nheprence Or Saluetic

2 He-24Unf. 1/a Long nex Meod Boit (Drined neded for Sorety Wirel mered Lengin Sis Long Minimum Moternal 450 or $150000 \mathrm{M} n \mathrm{nim}$ m relos Serength Order Number of Boits Eequired for Smpoing Cons to Br fabri

As ceen Conioiner Small Be Merted the

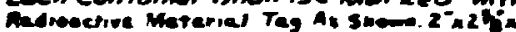
plare Aled Welle To The Cenpeiner.

Q4 Design As shown's sotis foctory fo Contaning Nofersol within im. Gonden Corrier No 2 Owg N I/G32 ENT Lemgen of Con Moy Ae Chonged As Ref

1 streas ealieve Completed Contoine a All Moiernal 3004 Stormless Sted.

- $\bar{A} \bar{x}$ Weld 5 mecificiorion In Aceordance mint A - WPs-302.1nsp. Met we-201 Sch. F.

A A. mreeds shall Be chesed wish stonderd smeoth frurses. Gleon. And Lutricoto with

As Giw Gasket in Groove.

$\Delta 10 \mathrm{OL} \cdot 3$

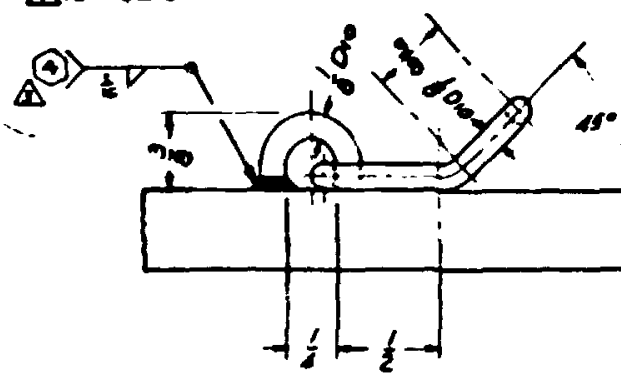

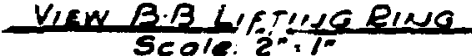

Not To Scenle 
BLANK PAGE 


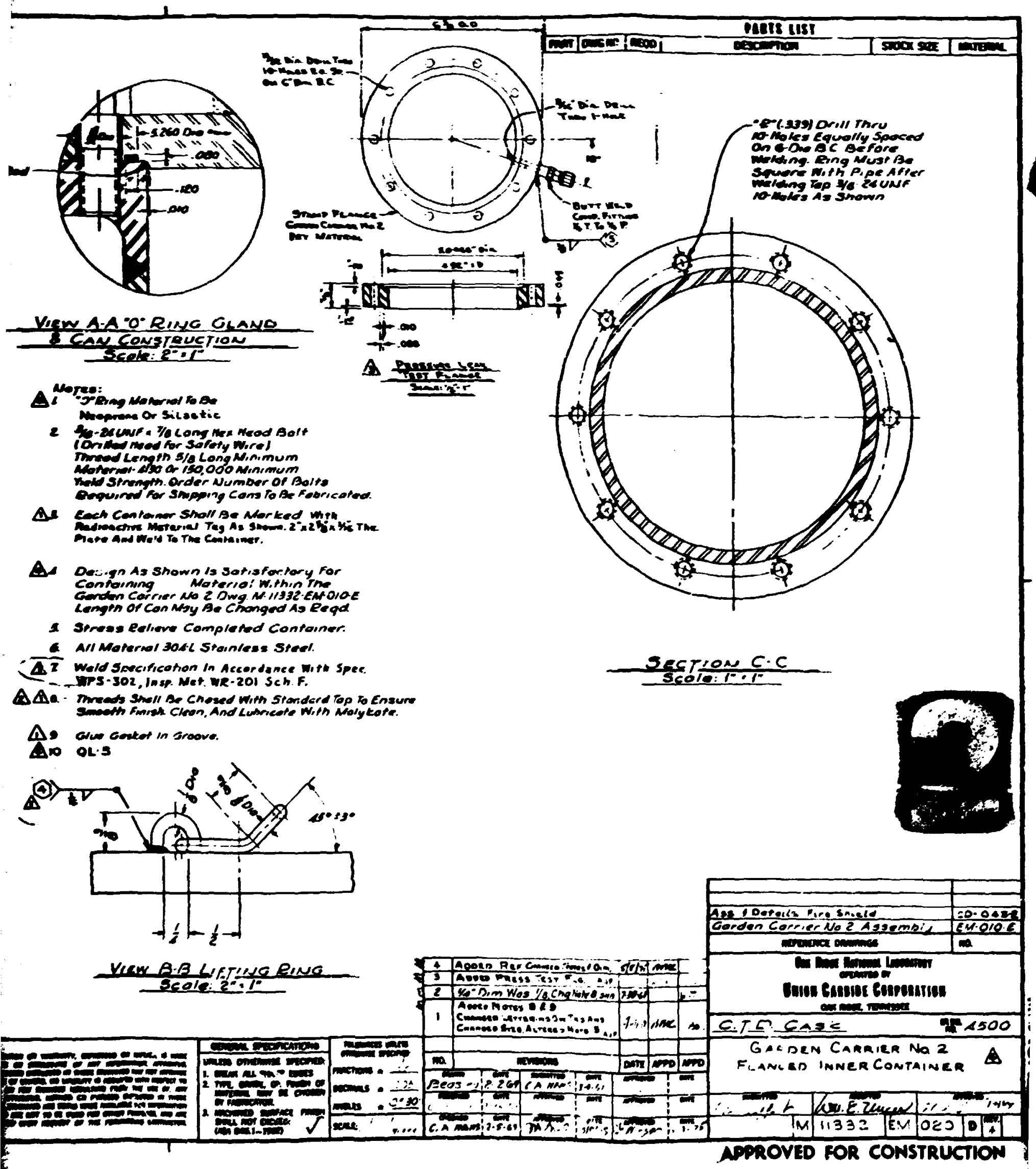


BLANK PAGE 

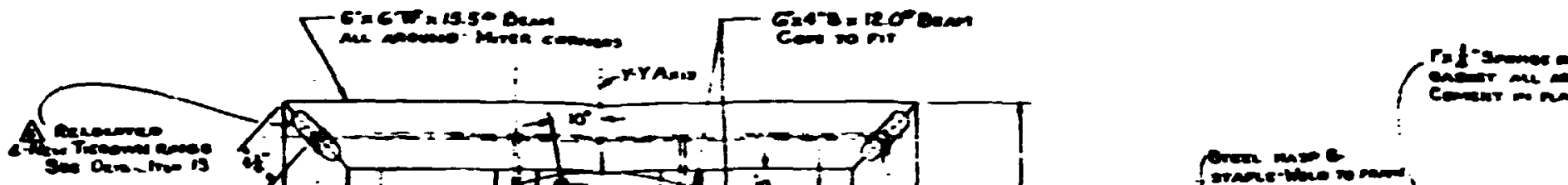

indaremenom

if Dour Tinen a moces

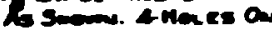
z-0uec 4-mazes

2-0bec 4-manes

beve eirm part so

Dew EM-OSO-O

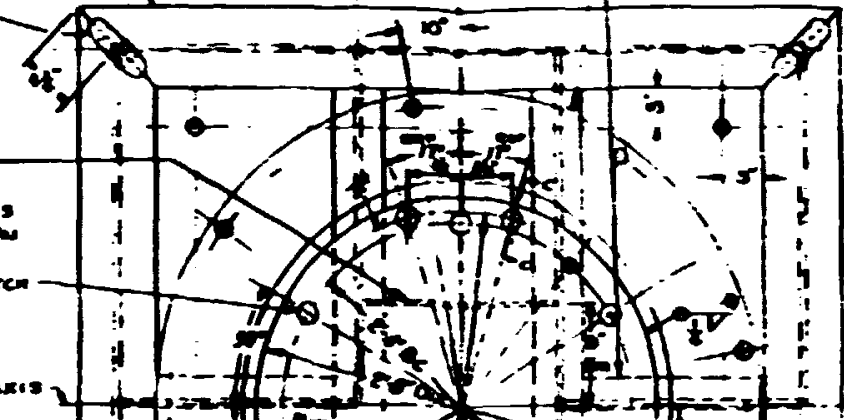

I-X Anes

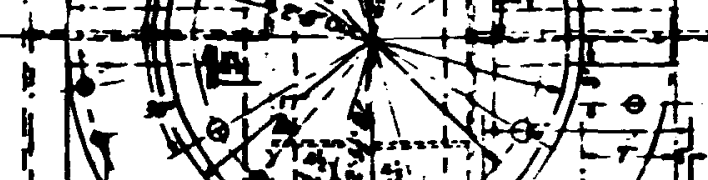

A
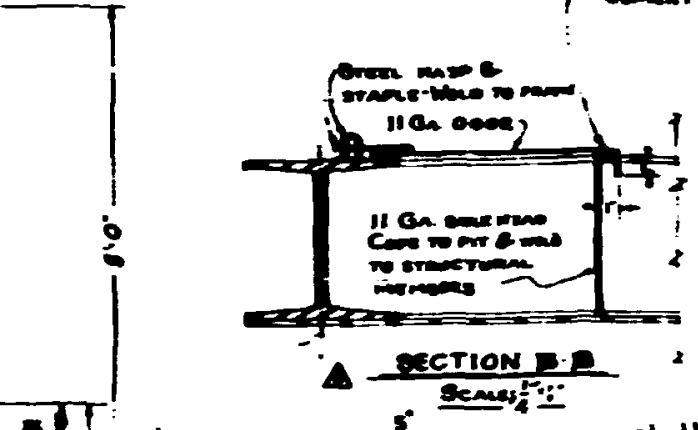

FISSILE RADIOACTIVE MHATERILL

OPON-8SII-174 WESHT 11,600 LOS

to Das Tras 6 equars weres

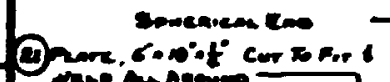 Grepis}

\section{(c)} o

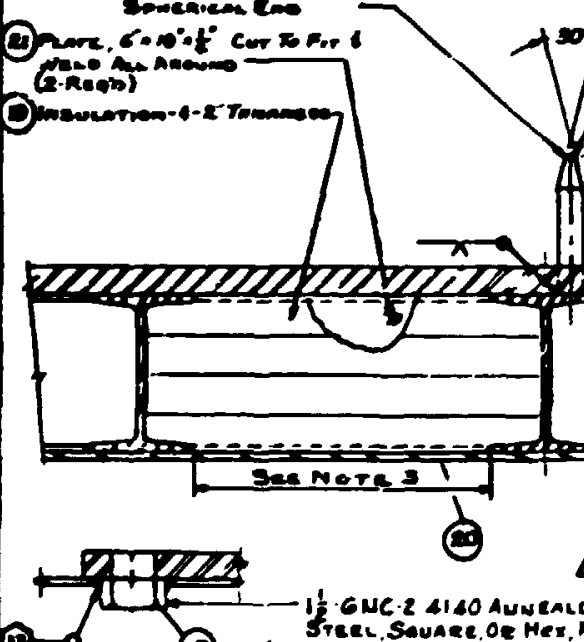

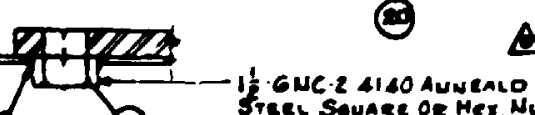

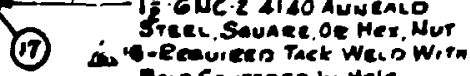

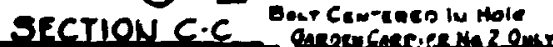

cratiti:1E

(5)

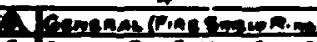

12

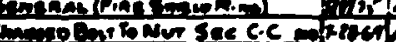

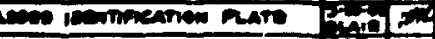

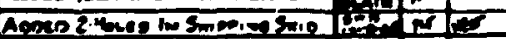

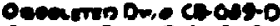

Acore one en as1.0

Romero has smosts.

II laver neres

$\operatorname{mos}$

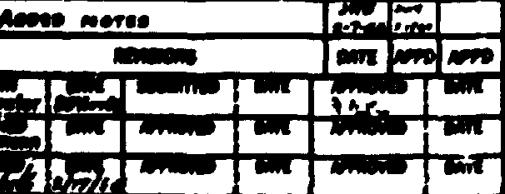

A-rection ax

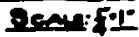

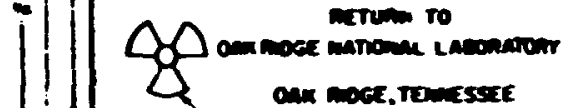

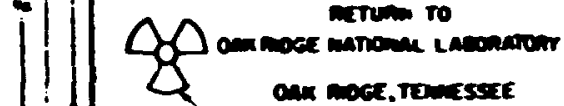

I

\section{DETAIL ITEN@}

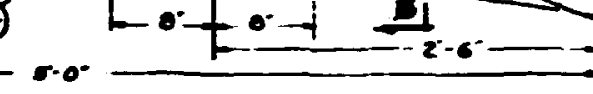

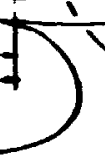

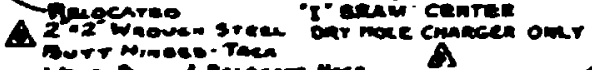
wers anse. I nuaccore mes

Notes

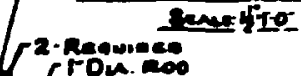

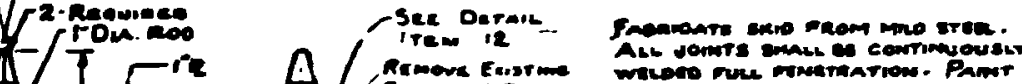

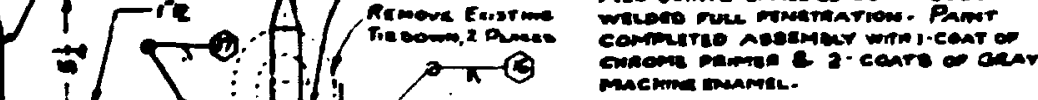

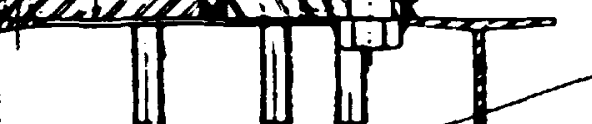

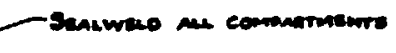

Dines

$5 \cdot 0-\times 5 \cdot-0 \cdot n t^{-2}$ DOT SP 5936

anx mace, Tumessice

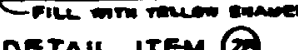

Lechere aw who on

T-ont \& Tep or

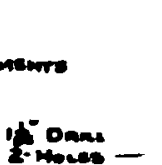
Danes -

1

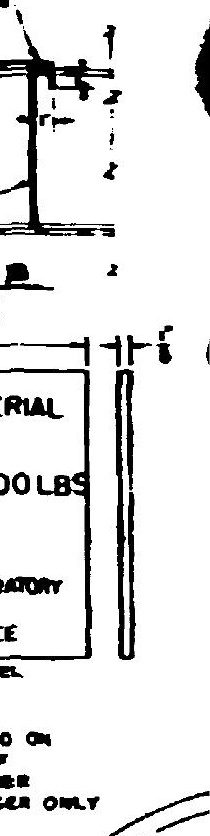


BLANK PAGE 


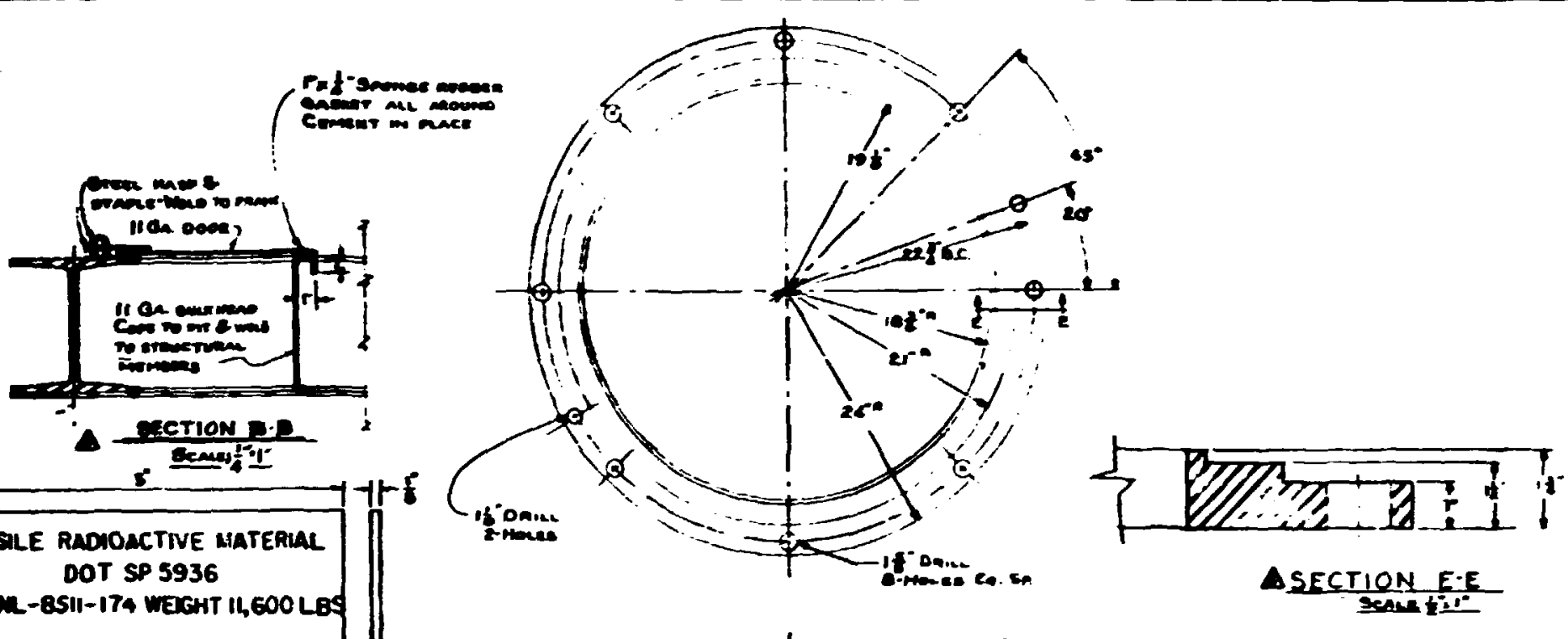

morum To

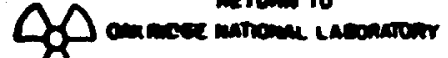

ons mose, rancsete

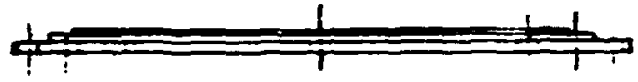

$\Delta \frac{\text { DETAL ITEM (II) }}{\operatorname{TSI}}$

DETALL ITEM (2)

cocare an wero on

Font to of

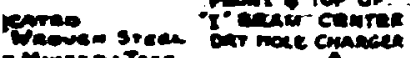

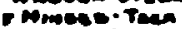

i Here. Ruccare mas

as

Pram mo onas.

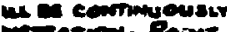

minargeo. Pazw

Mor mini-cent ex.

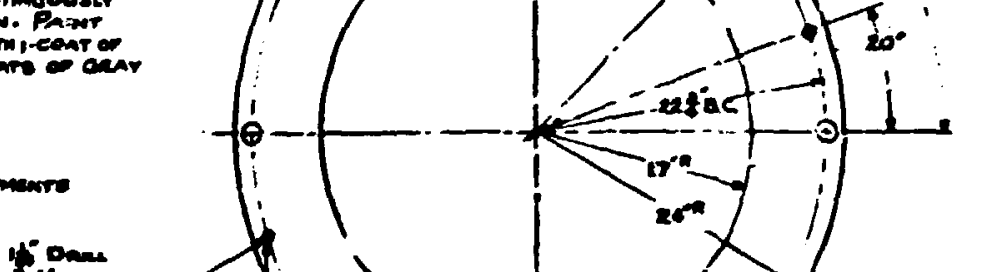

Fone.

cravere omr 
BLANK PAGE 


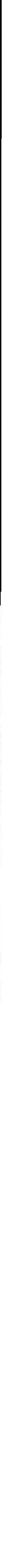


BLANK PAGE 


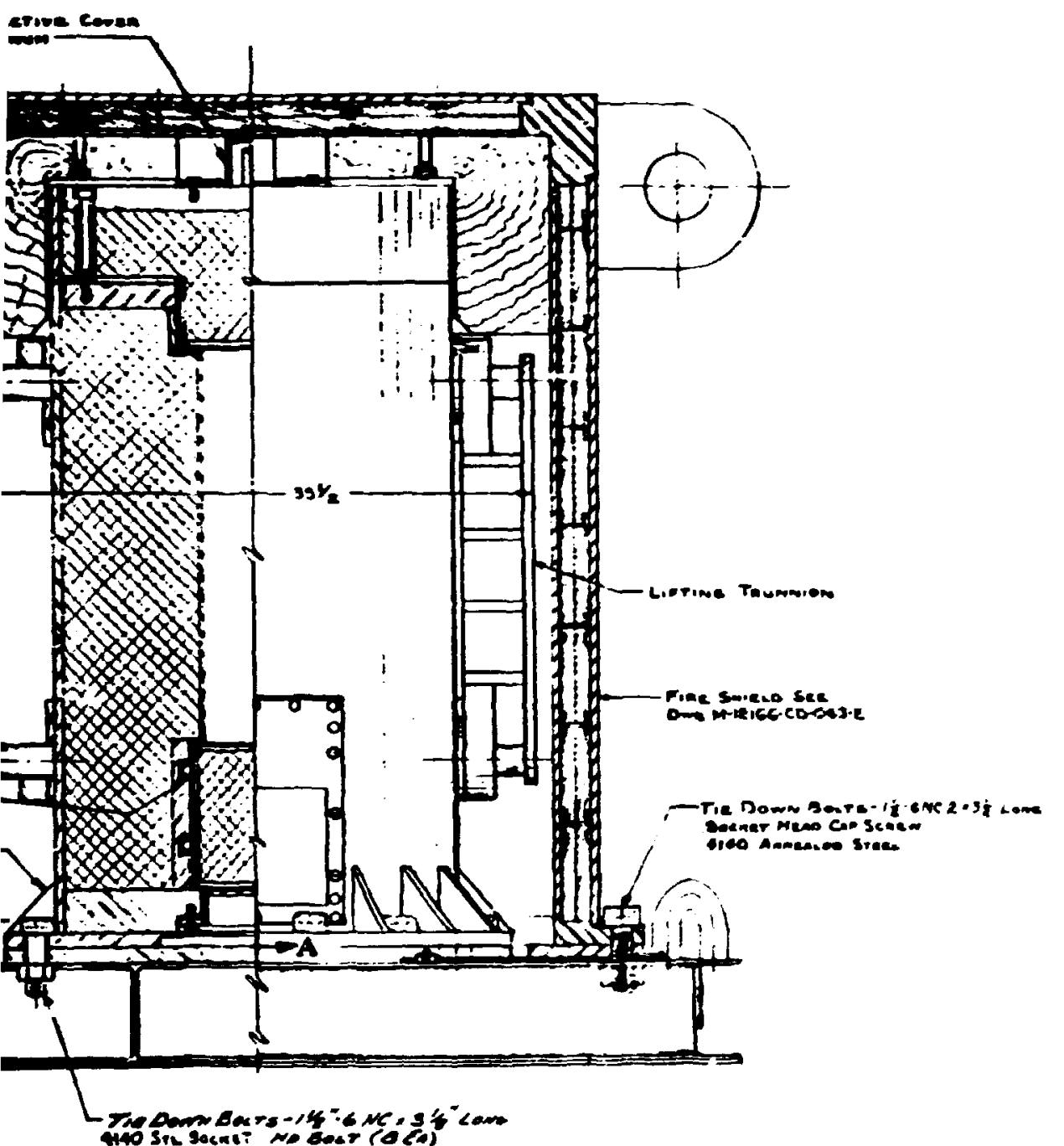

$$
\begin{aligned}
& \Delta \text { Generi Gaperes No } 2 \\
& \text { sease-tan }
\end{aligned}
$$
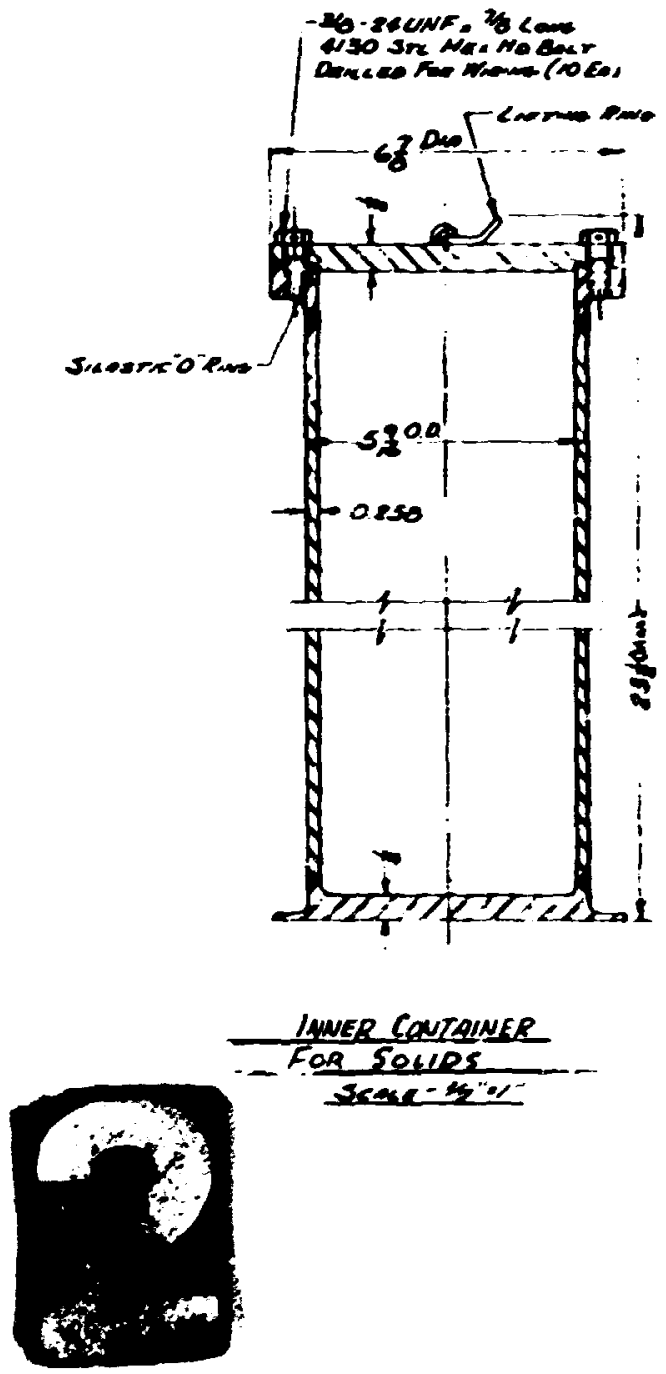

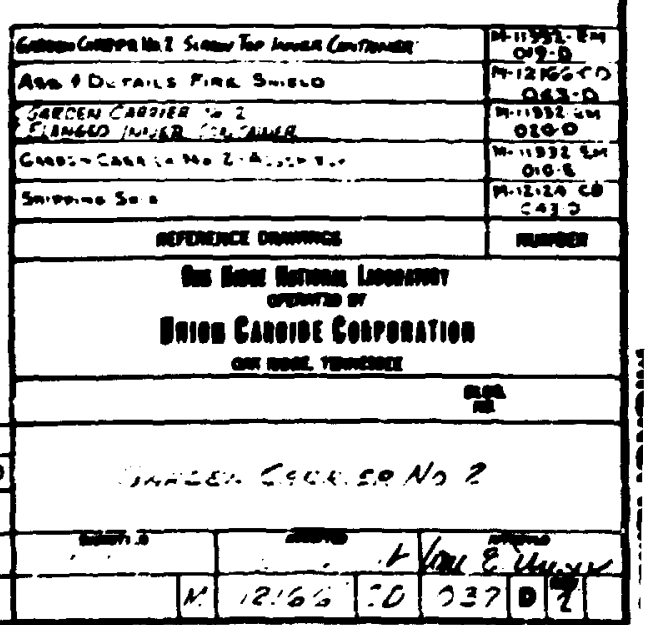




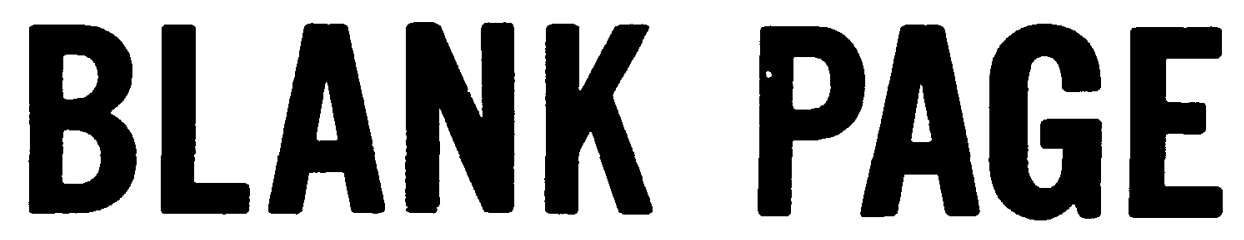



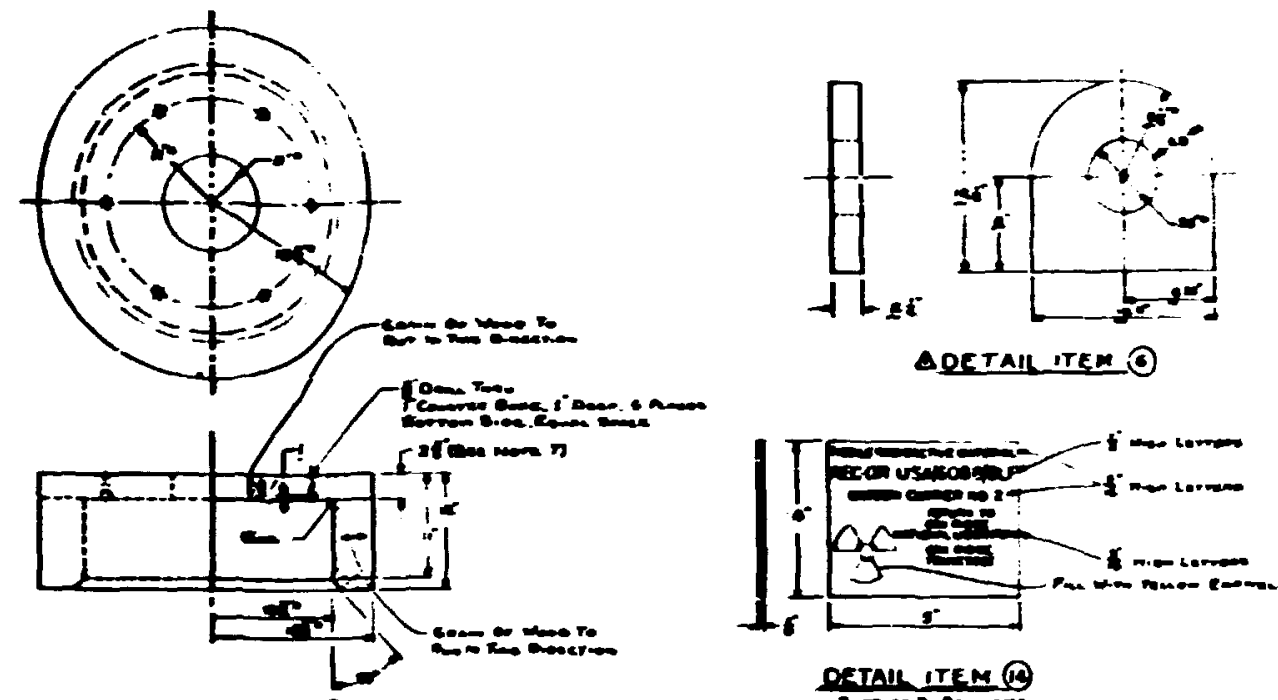

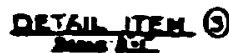

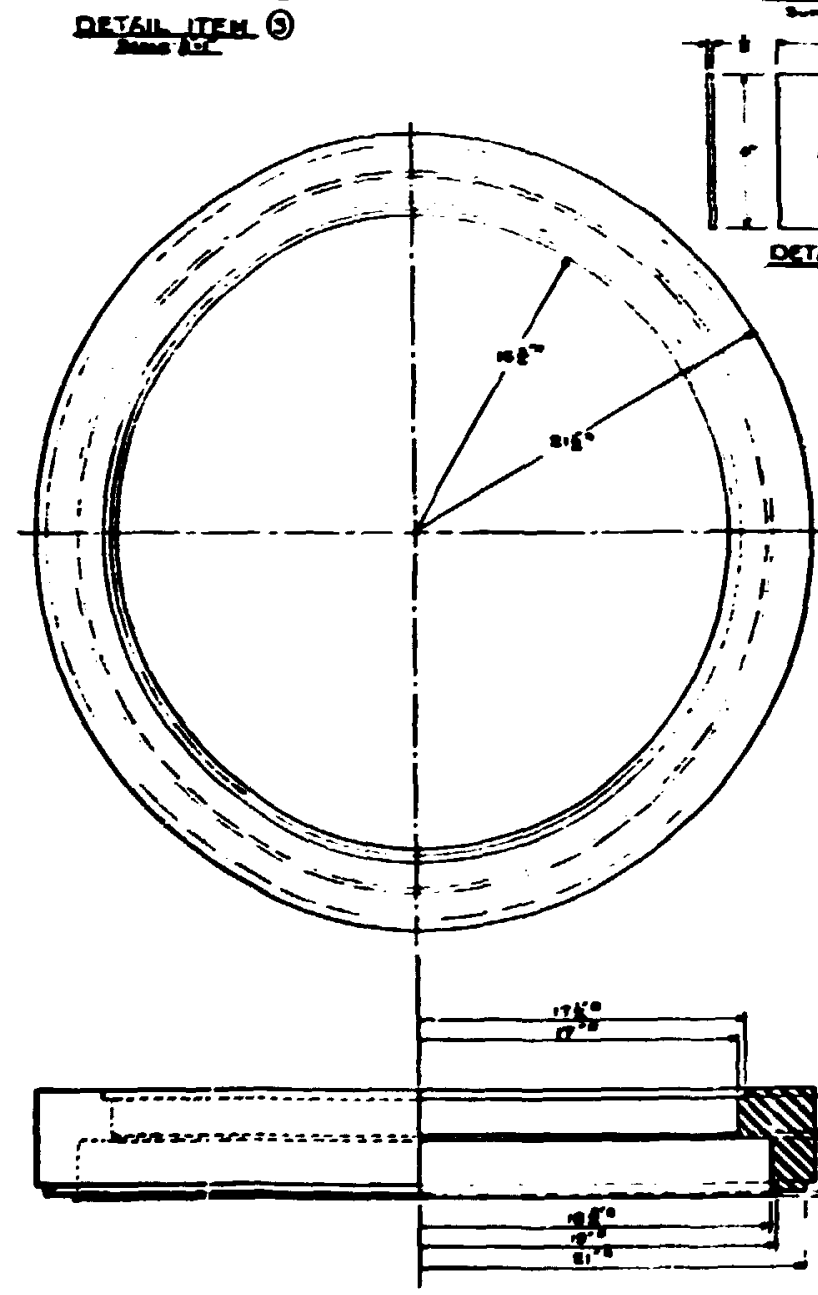

netringerse

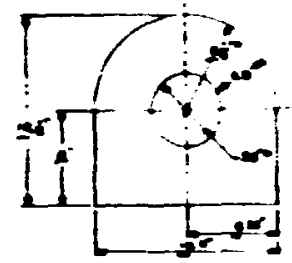

DOETALITEMO

Merre:

mo- ch

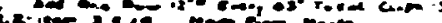

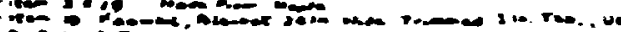

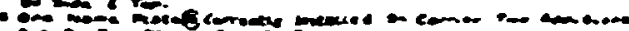

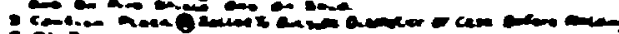
A T.

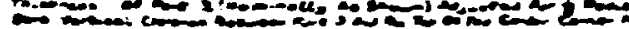

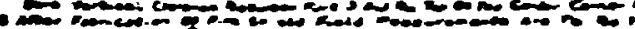

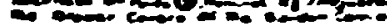

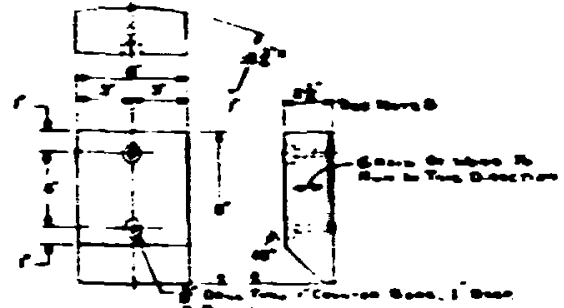

DETAL ITFA (B)

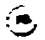

(I)

DETAU ITEMQ

oxestion

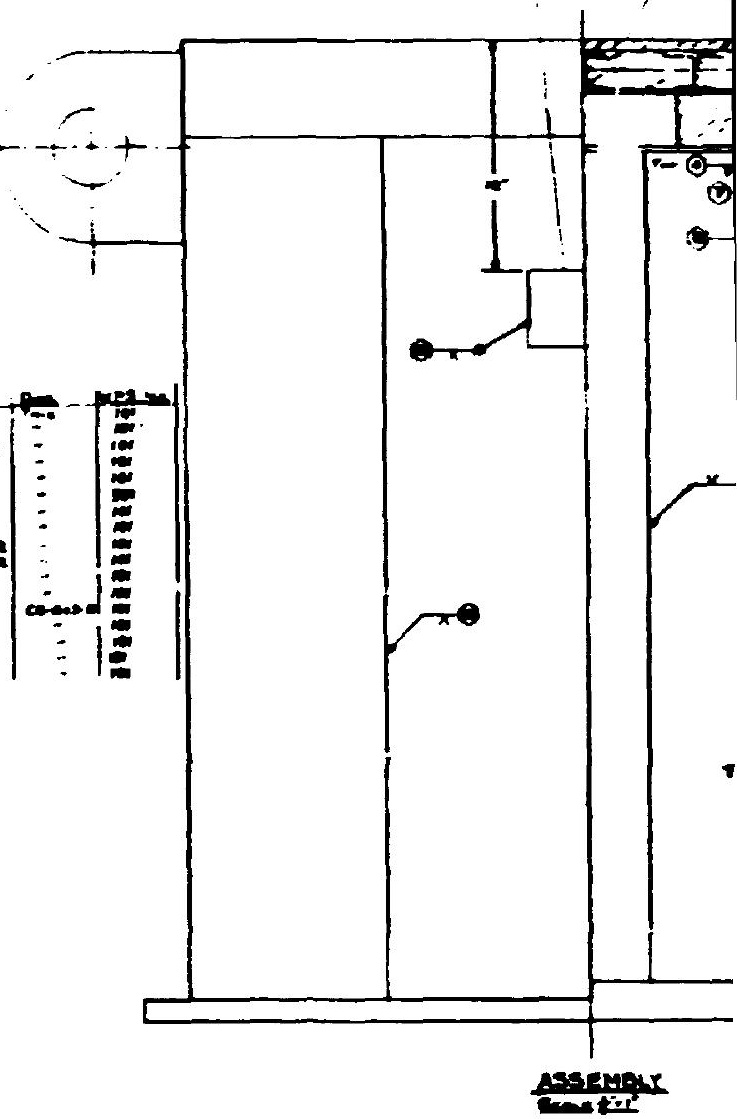




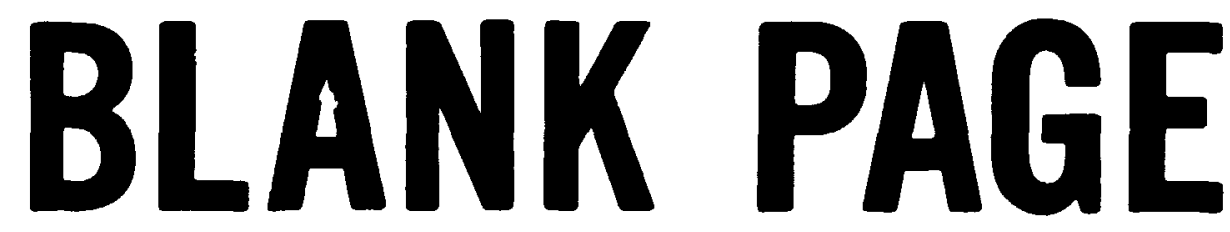




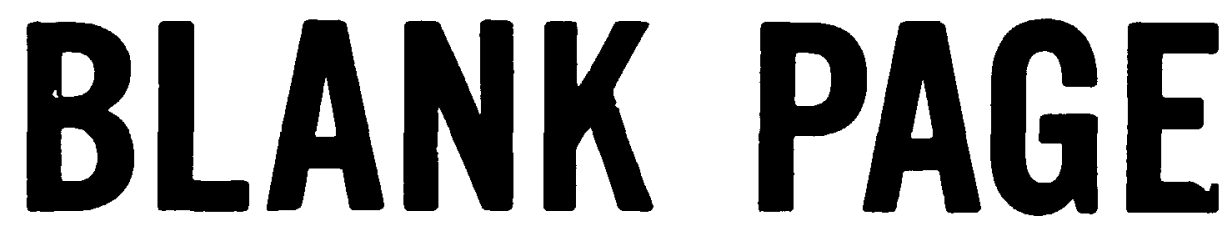




\subsection{Appendix B - Approval Documents}

Page No.

Department of Transportation Special Perait No. 6088

dated Oct. 1, 1969

101

First Revision DOn Special Peratt No. 6088 dated

Aug. 5, 1971

102

6088/BLF dated Sept. 21, 1973

ORKL Nuclear Safety Review NSR 742 dated June 17, 1974

103

Letter of Approval of SARP after Review by ORNL Transportation Comittee, R. M. Ring to R. D. Seagren dated Nov. 30, 1977. 
BLANK PAGE 


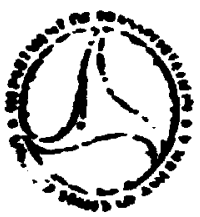

\author{
DEPARTMENT OF TRANSPORTATION \\ HAZARDOUS MATERIALS REGULATIEAS EOARD \\ washineton. D.C. 20590
}

SPECIAL PERMT No. 6088

This special permit is issued pursuant to 49 CFR 170.15 of the Department of Transportation (DOT) Hazardous Materials Regulations, as amerded, and on the basis of the August 11, -969, petition by Oak Ridge National Laboratory, Oak RIdge, Tennessee.

1. Shipments of fissile and large quantities of radioactive anterials, n.o.s., are hereby authorized in the packaging as described in this special permit. This packaging, when constructed and assembled as prescribed herein, with the contents as authorized herein meets the standards prescribed in the DOr regulations, Sections $173.395(c)(2), 173.396(c)(3)$, and 173 . 398(c). Shiprents must be in accordance with the provisions of the U. S. Atomic Energy Commission (USAEC), Oak RIdge Operations Office approval number 69-014 dated August 4, 1969, and as further provided for herein.

2. Each shipper, under this permit, other than the petitioner naned above, shall register his identity with this Board prior to his first shipment, and shall have a copy of this permit in his possession before making any shipment.

3. The packaging authorized by this permit consists of leadfilled, steel cask weldment, which is a right cylinder approximately 25" in dianeter by $49^{\prime \prime}$ high, welghing about 8500 pounds, with a $7^{7}$ dianeter by $24^{\pi}$ deep cavity. Approximately $83 / 16^{n}$ of lead shielding is provided. Contents are loaded within DOT Specification $2 R$ or equivalent inner contalnment. The package Is Identified as the Garden Carrier Number 2 Shipping Cask, and is described on Oak Ridge National Laboratory's drawing number -M-12166-CD-037-D and in the attachment to the USAEC Certification.

4. The contents of each package authorized by this permit consist of fissile and large quantities of radioactive material a.0.s., In the form of unirradiated and irradiated fuel elenents and contained sections of fuel elements with solid and 1iquid axed fission products, or waste products. Liquids will be concained in primary polyethylene or stainless steel bottles within 
the DOT Specification $2 R$ containment vessel. The maximum thermal decay energy of the contents is 100 watts. The fissile content is limited to not more than 500 grans of uranium-235, $350 \mathrm{grams}$ of uranium-233 or plutonium, or 350 grams of any combination thereof.

5. The packaging authorized by this permit meets the requirements for shipment as Fissile Class $I$. The transport index must be assigned based on external radiation levels.

6. The outside of each package must be plainly and durably marked "DOT SP 6088", in connection with and in addition to the other markings and labels prescribed by the DOr regulations. Each shipping paper issued in connection with shipments made under this permit must bear the notation "DOr SPECIAL RERMIT NO. 6088", In connection with the commodity description thereon.

7. Each package must have its gross weight plainly and durably marked on the outside of the package.

8. This permit authorizes shipments only by motor vehicle, and rail.

9. The shipper is required to furnish an experience report to this Board before expiration of the permit and when any mendment is requested. This report must include the approximate number of packages shipped, and the number of packages involved in any loss of contents. The modes of transportation used for these shipments must also be shown.

10. Prior to each shipment authorized by this permit, the shipper shall notify the consignee of the dates of shiprient and expected arrival. The shipper shall notify each consignee of eny special loading/unloading instructions prior to his first shipment.

11. Any incident involving loss or contents of the package must be reported to this Board at the earliest feasible moment followIng the incident. 
12. This permit does not relieve the shipper or carrier from compliance with any requirement of the DOT regulations, except as specifically provided for herein.

13. This permit expires September 30, 1971, and may be revoked for cause at any time.

Issued at Washington, D.C.:
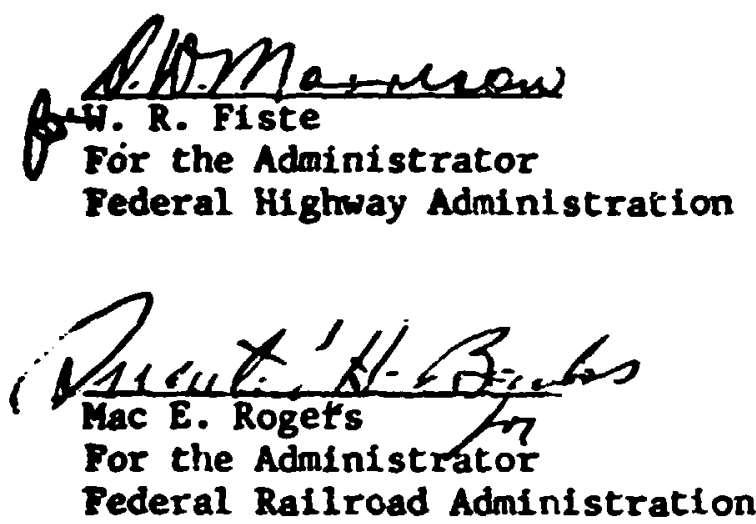
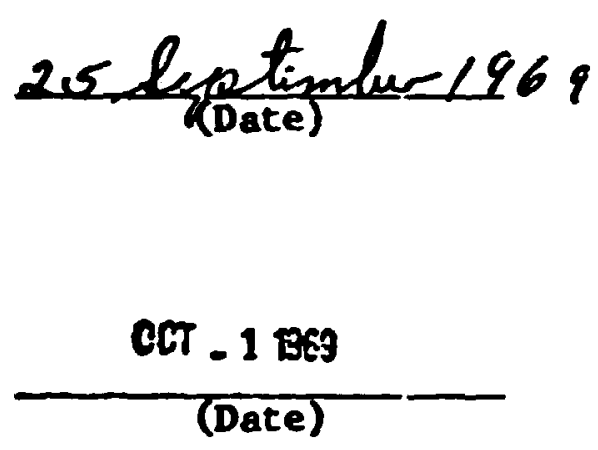

Address all Inquirles to: Secretary, Hazardous Materials Regulations Board, U.S. Department of Transportation, Washington, D.C. 20590. Attention: Special Permits.

Dist: a, d,e, h, l 


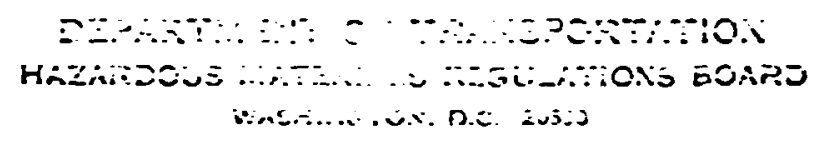

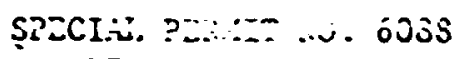

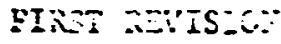

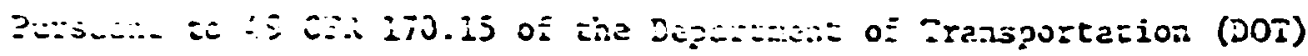

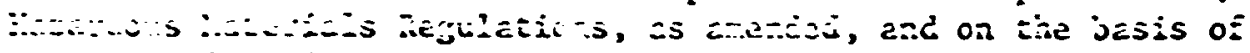

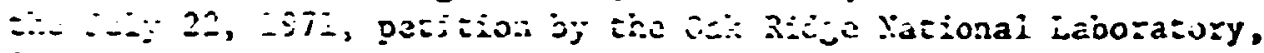

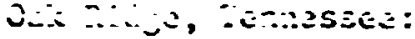

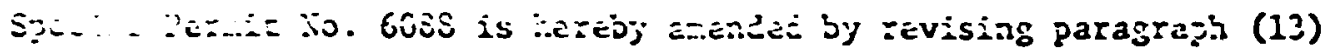

$=0: \ldots . . .3$ so:iot:s:

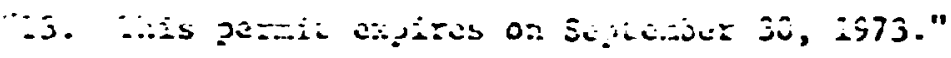

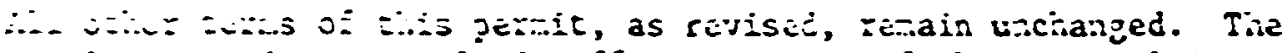

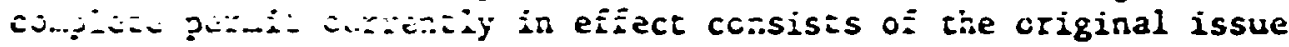

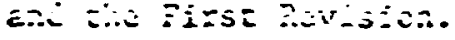

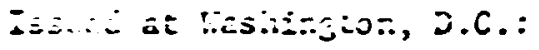
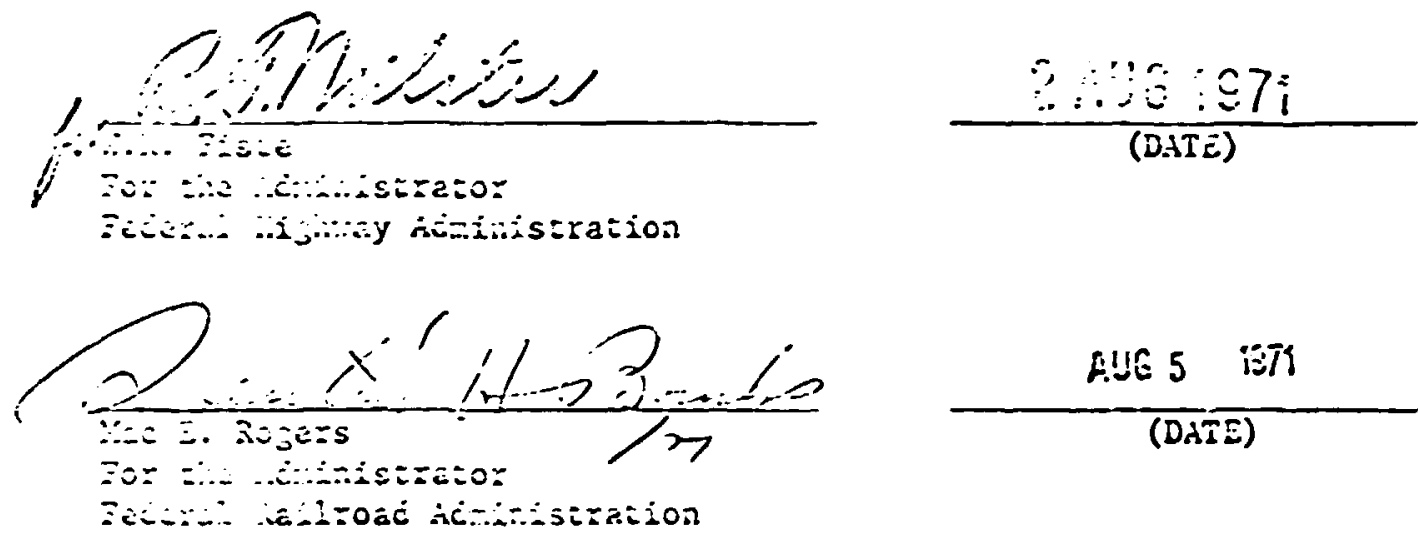

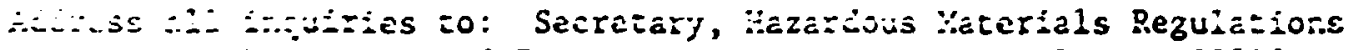

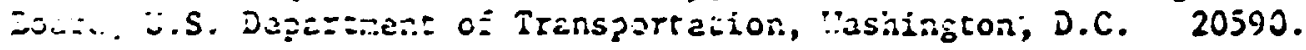

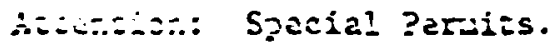

Disi: $=i, e, h, i$

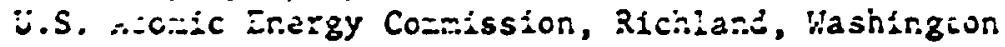




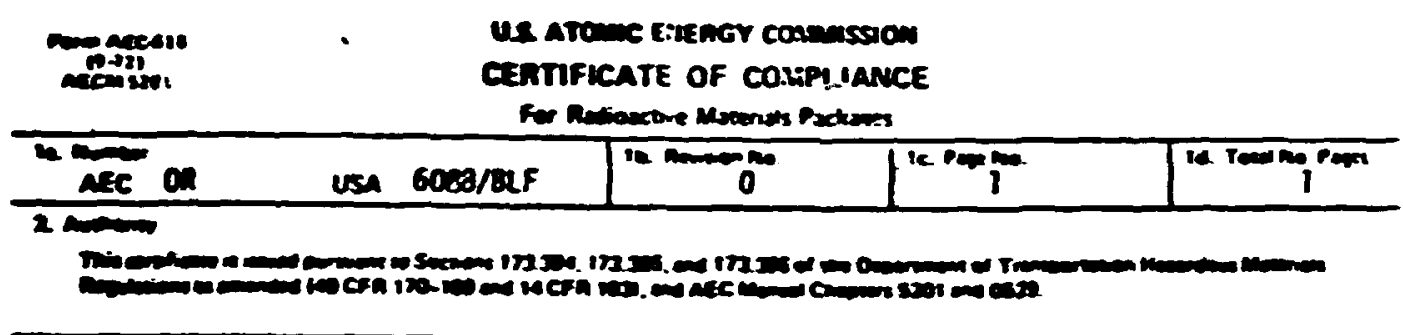

\section{2 comornous}

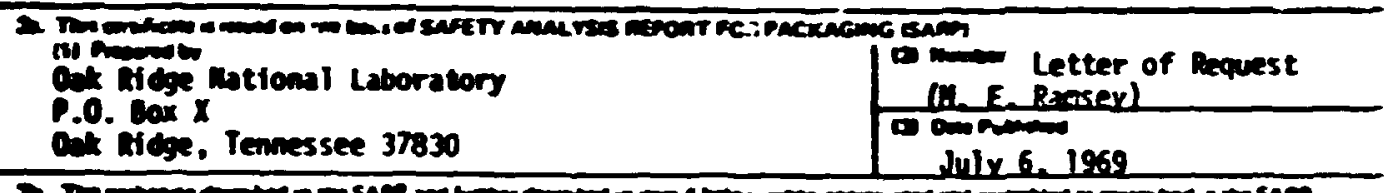

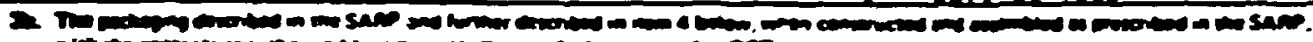

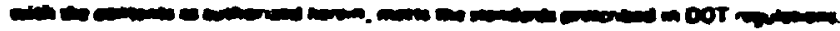

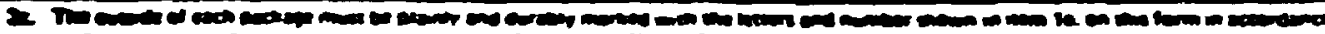

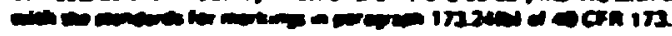

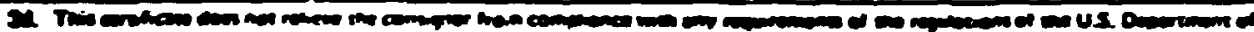

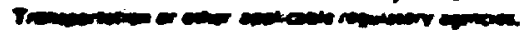

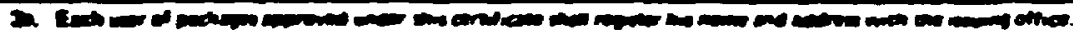

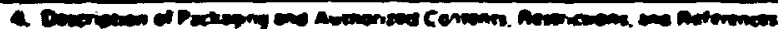

a. The packaging consists of a lead-filled, steel cask welctent, which is a right cylinder

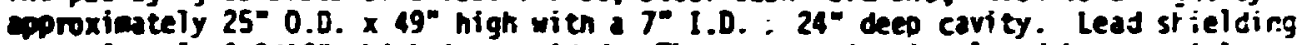
eppraxfmately 8-3/16" thick is provided. The TOD opening is closed by a stainless steel clad lead srield. The bottom opening has two stainless steel clad lead srieldes opposing steoped sliding drawers. All opening; are sealed with neoprene gaskets. [as:tents are loaded within COT Specification $2 R$ or equivalent inner containtent. The gross weight is approxicately $8500 \mathrm{Ib}$.

B. The authorized contents of each package consists of fissile and large quantities of radioactive materials, M.0.S, in the form of urirradiated and irradiated fuel elerenis and contained sec ions of fuel elerents with sclid and linuid mixed fission procucts, or waste products. Liouids will be contained in oriagry colyethylene or stainless steel bottles Hitiin :he COT Scecification 29 Cnntair-ant vessei. The maxin m itremei decay energy for solid nonfissile radioisotooes is 100 viatts and for liquid asnissitit radtoisotopes is $\$ 1.5$ watts. Tre fissile conterit is lirited to not more than 500 g $0:$ 235U, $350 \mathrm{~g}$ of $23: \mathrm{U}$ or $\mathrm{Pu}_{\mathrm{u}}$, or $350 \mathrm{~g}$ of any combination thereof.

C. Shiprenis are suitrizen is Fissile Class $j$. The Transport Index is assigned on the basis of external :aciation levels.

D. Shipments are authorized b; rotor ighicle and rail.

\begin{tabular}{|c|c|}
\hline \multicolumn{2}{|c|}{ TO GE COFPLETEJ ST AEC } \\
\hline 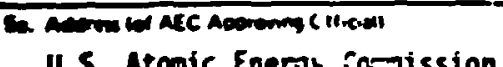 & 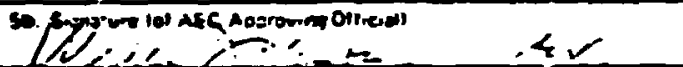 \\
\hline odi Ridge, Tennesses 37830 & 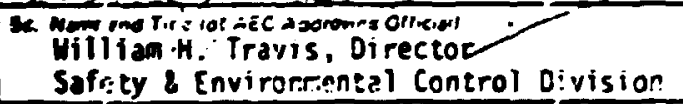 \\
\hline & 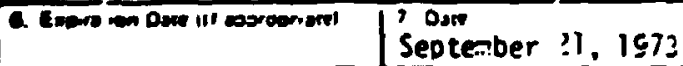 \\
\hline
\end{tabular}




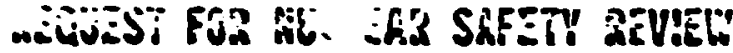

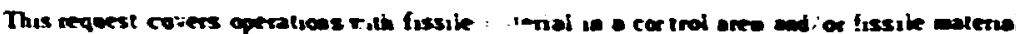

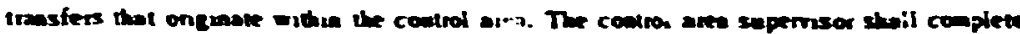

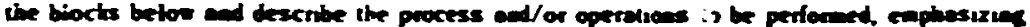

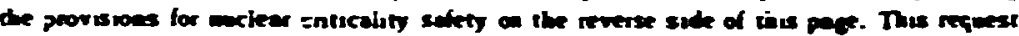

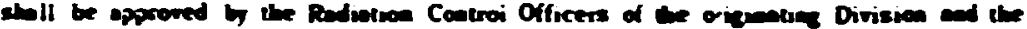

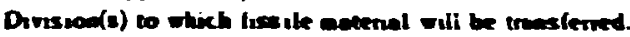

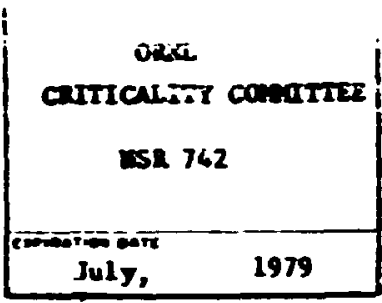

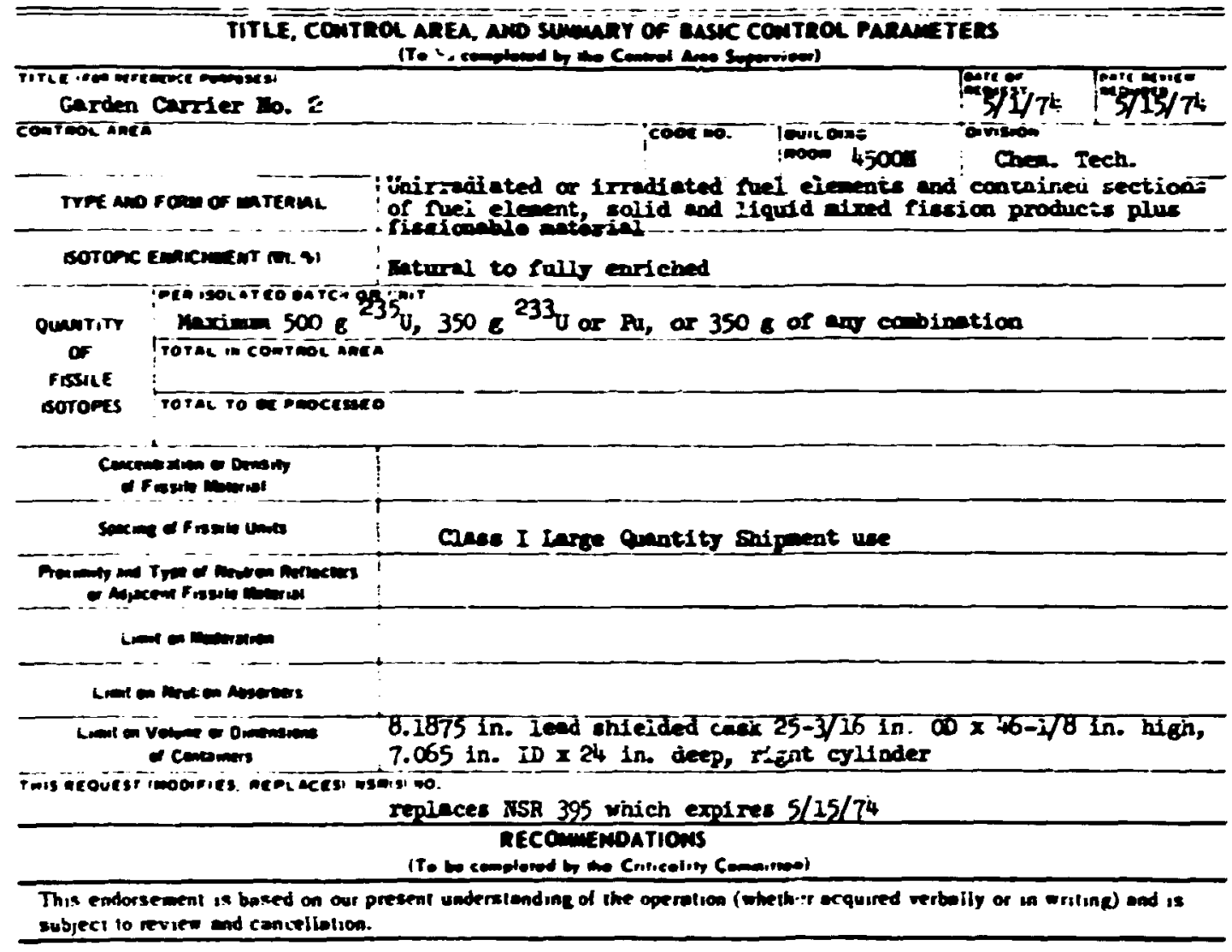

The 9-1n.-trick lead-steel shield surrounding the ficsile anterial, effectively lsolses the Ilated quentity of floefle payloed, thus eifainating effective interaction betveen sinilar, adjecent, cesics. The requlresents of Fissije

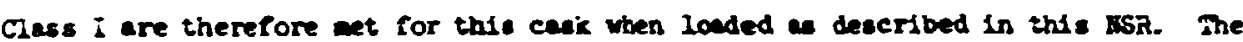
proposed ioadinger are epproved.

$$
\text { rec - J. P. Kichoig. }
$$




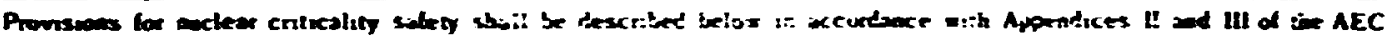

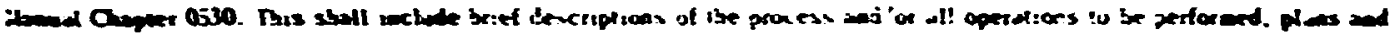

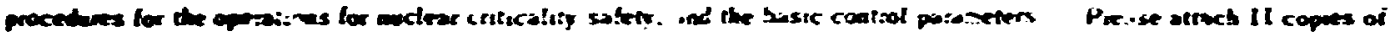

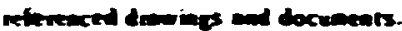

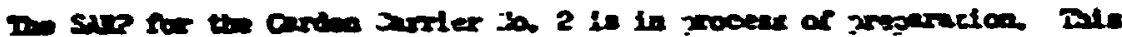

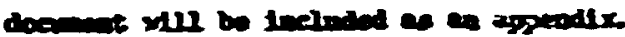

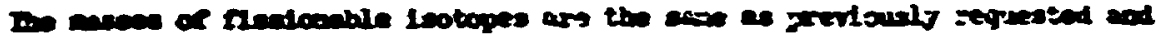

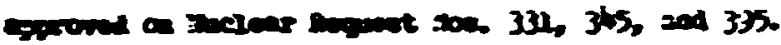

Onar. CRITICALITY CONATTEE

ISR 742

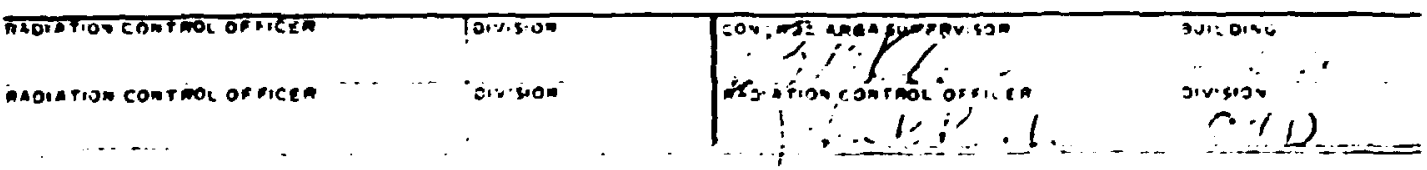




\section{INTRA LABORATORY CORRESPONOENCE}

oAK RIGUE national laHORATORT

November 30,1977

TC 75-6

To: R. D. Seagren

From: Transportation Committee

Subject: SARP of the ORN: Garden Carrier No. 2 -Draft

The Committee has reviewed the subject draft dated November 10, 1977. At tached are comments made by individual members of the Committee for changes needed or suggested. The SARP is approved for technical content and approach -- with the expectation that you will make a positive response to the comments. (If you have any question concerning the comments, please contact the individual making the comments.)

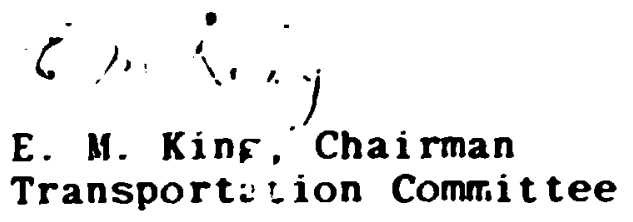

EMK : bb

cc: Transportation Committee

G. H. Burger

J. A. Cox 


\subsection{Appendix C: Computer Program to Cakubte \\ Cormer Drop Nezative Acceteration Forces}

\section{Program 1001 Cask}

Derivation of Equations

When a cask constructed of a single. ideally plastic material impacts on its top comer. the majo: portion of the kinetic energy will be dissipated through dispheement of material in the impact are. An idally ptastic material is a material that has a constant stras for all vaives of stran.

The expression

$$
\mathbf{d U}=\mathbf{S} \mathbf{d} \mathbf{V}
$$

where

$S$ = the quantity of energy required to displace a unit volume of material:

$V=$ the displaced volume of material and an be used as a basis for determining the effect of the top-comer impact. (The lack of an accurate numerical value of $S$ necessitates a conservative estimation of its balue.):

I = the kinetic energy.

With reference to the computational diagram illustrated in Fig. C.I. it may be said that

$$
d V=I 2 X Y d Z \text {. }
$$

By trigonomety.

$$
\begin{aligned}
X & =r(\cos B-\cos A) . \\
Y & =X \tan a=\tan a r(\cos B-\cos A) . \\
d Z & =r \cos d B .
\end{aligned}
$$

If follows that,

$$
d U=S X Y d Z 2 .
$$



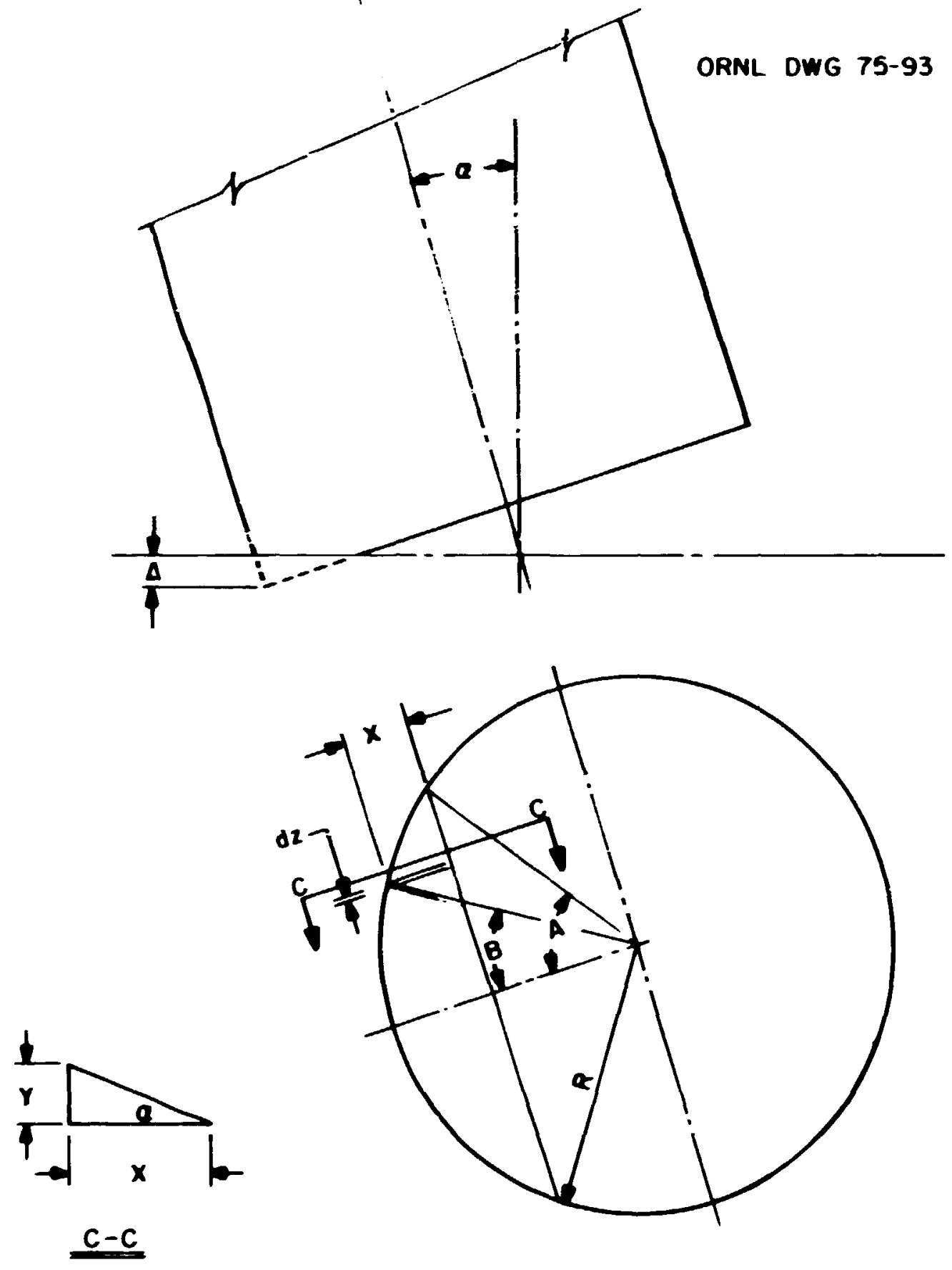

Fig. C.1. Model for corner drop calculations. 
and

$$
U=\Sigma d U=\Sigma S X Y d Z 2 .
$$

This expresion on be readity solved using the computer. A value for the angle. A. an be assemed and $B$ incremented from $-A$ to $A$ or from $O$ to $A$ if the result is multiplied b; two and the enery required for the assumed seformation is computed. A is started small. increncaned, and the energy required is compared with the ast's potential energy. In this

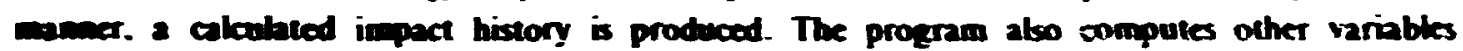
using the expresions betow. The maximum deformation. $\Delta$. is found in the following manner:

$$
\Delta=\sin a(1 \operatorname{Cos} A)(r)
$$

The appliad force, F. F $=d U: d \Delta$, and the acceteration, a. was computed from the following equation:

$$
\mathbf{a}=\mathbf{F} \mathbf{E}
$$

The velocity at any increanent is found from the following kinetic energy principk:

$$
\Delta K E=U=(M / 2)\left(V_{0}^{2}-V^{2}\right)
$$

or

$$
V=\left(V_{0}^{2}-2 U / M\right)^{1 / 2}=\left[(2 / /)(Y / h-v]^{1 / 2}\right.
$$

where

$$
\begin{aligned}
& V_{0}=\text { initial velocity, } \\
& M=\text { cast mass, } \\
& \mathbf{W}=\text { weight, } \\
& \mathbf{b}=\text { drop height, } \\
& \mathrm{B}=\text { grevitational constant. }
\end{aligned}
$$

The time is computed from the relationships 
$2=\mathbf{d r} \mathbf{d t}$.

or

$$
d t=d v .
$$

and sirsmary rechniques.

The computer progeram is given and the results for specific energies of 100.000 and 260.000 in-lb in." are given. The plots of the negative accelerations versus deformation are given in Fies. C.2 and C.3. 


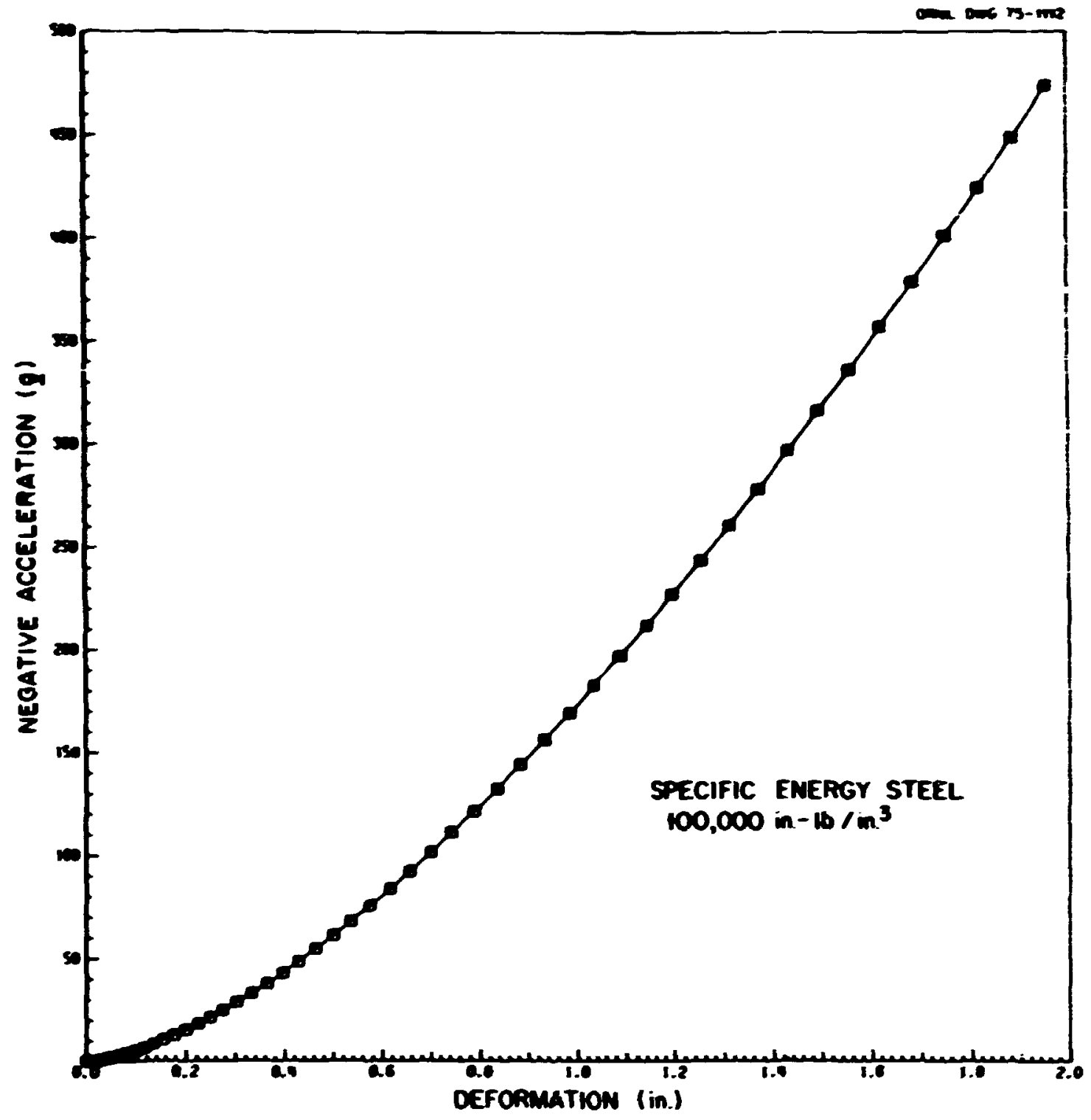

Fig. C.2. Plot of negative acceleration vs deformation at a specific energy of $100,000 \mathrm{in} .-1 \mathrm{~b} / \mathrm{in} .^{3}$ for steel for the $30-\mathrm{ft}$ corner drop. 


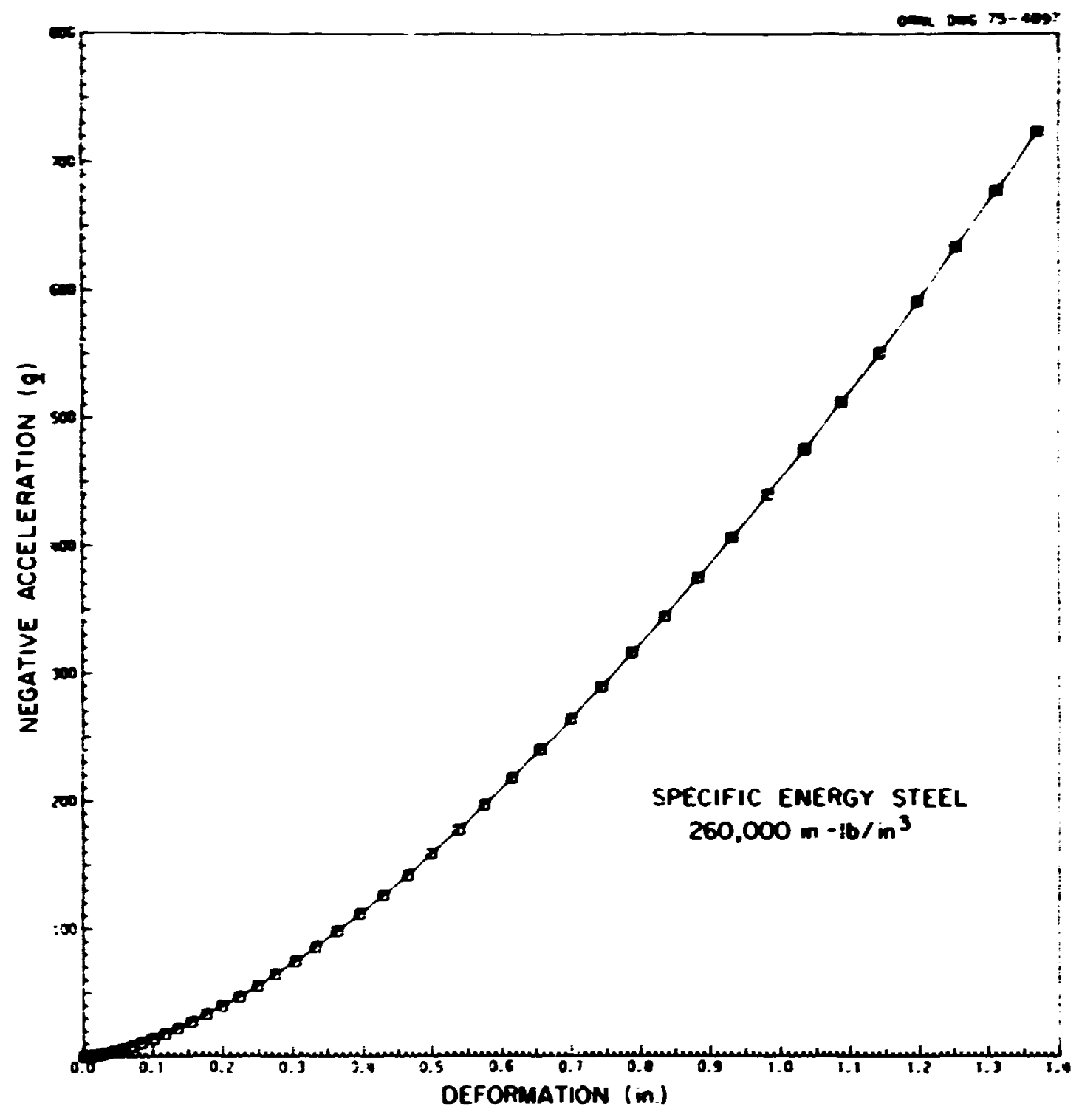

Fig C. 3. Plot of negative acceleration us deformation at a specific energy of 260,000 in.-1b/in. ${ }^{3}$ for steel for the $30-f t$ side drop. 


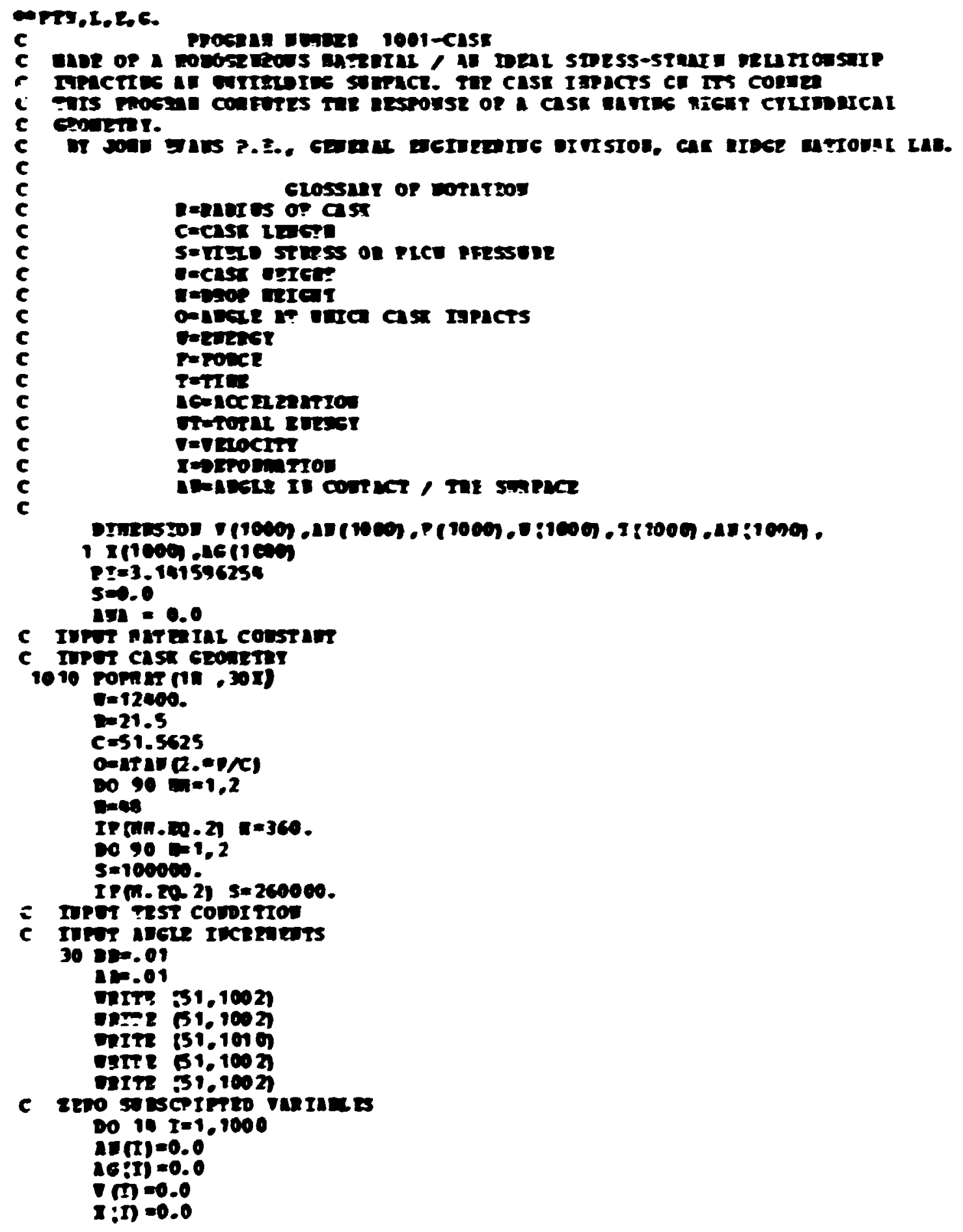




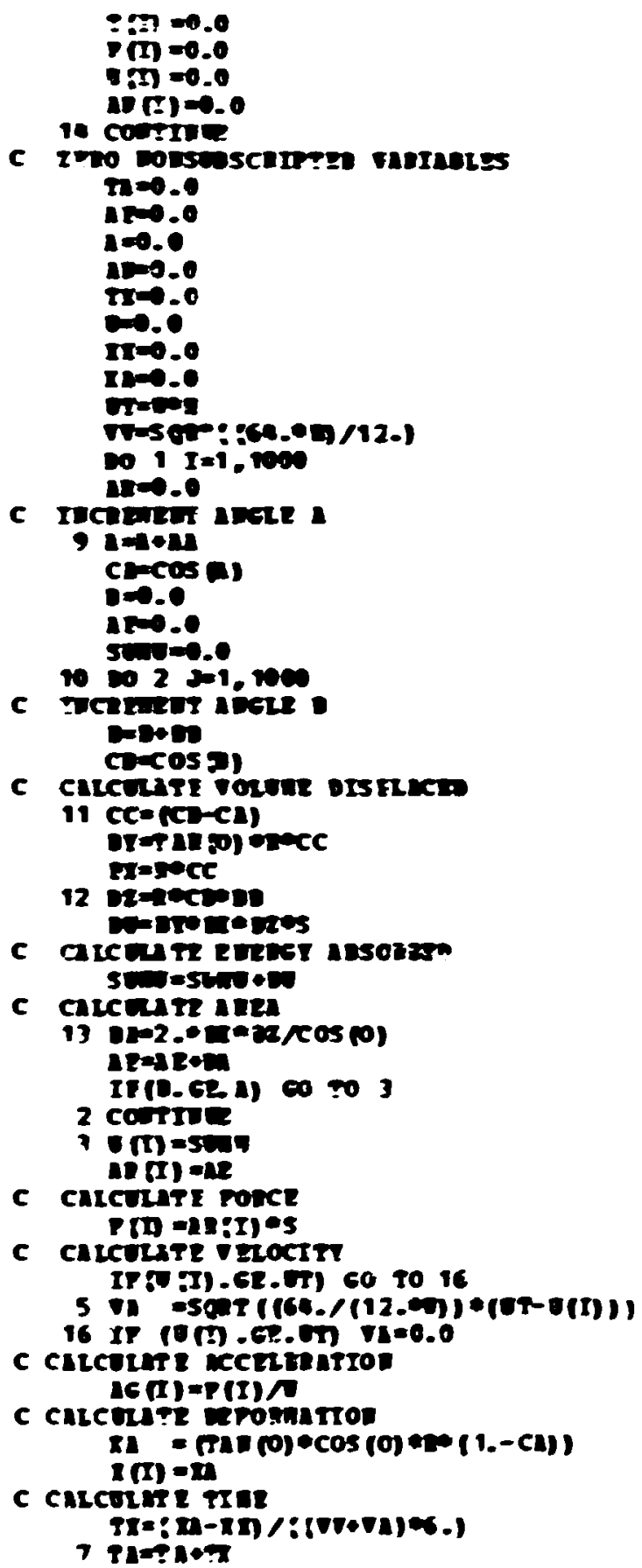

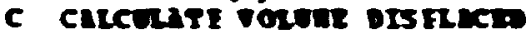

$11 \mathrm{ce}=(\mathrm{CD}-\mathrm{Ca})$

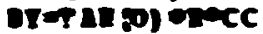
Frasece

12 er=20000 contertenzes

c aremin entest assonism sting $=5+m$ on

c calcuntr inea

13 ox-2 - $0=22 \pi \cos (0)$ Izasera 


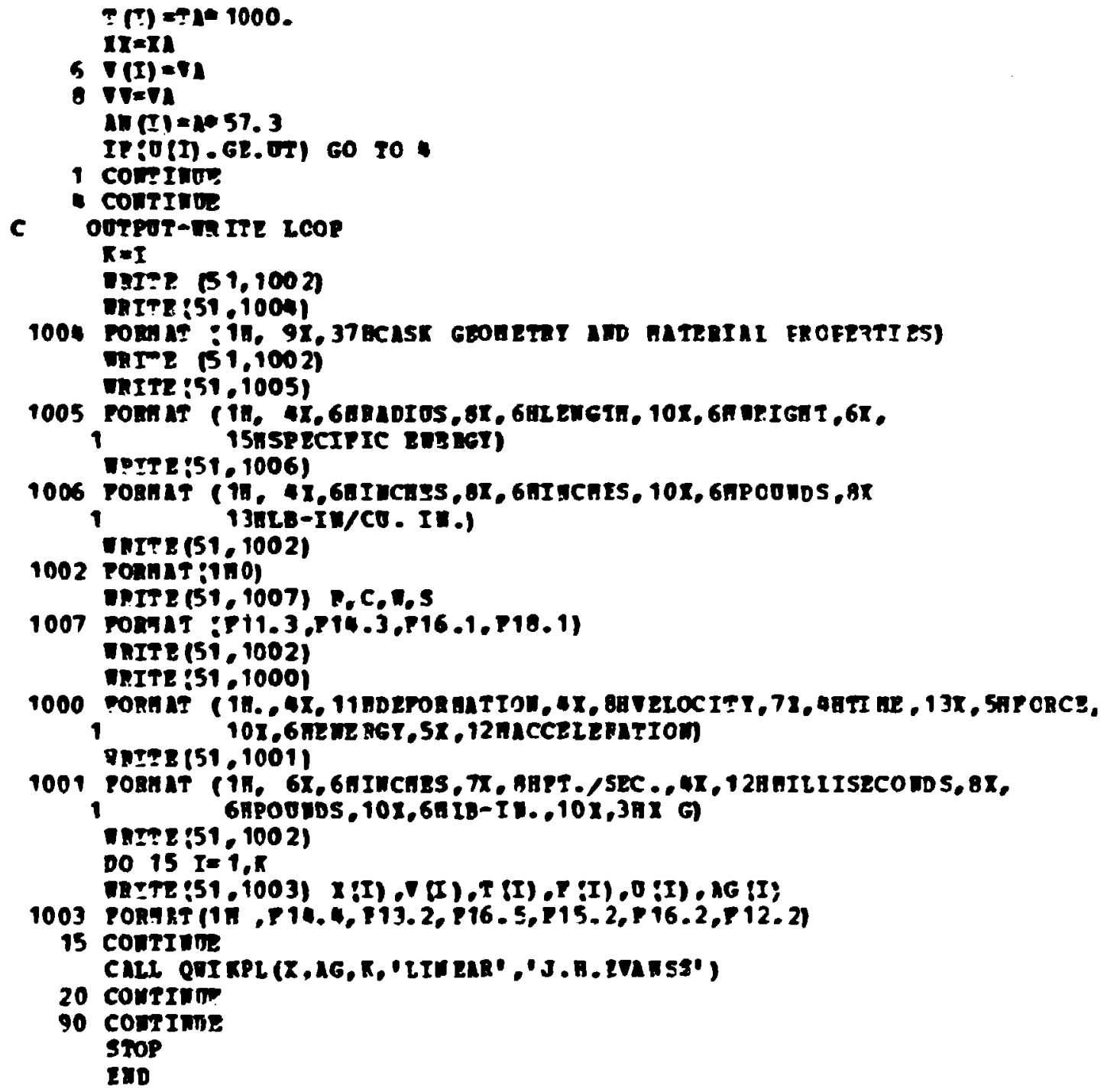


Cast czonztet ato engenial popenzis

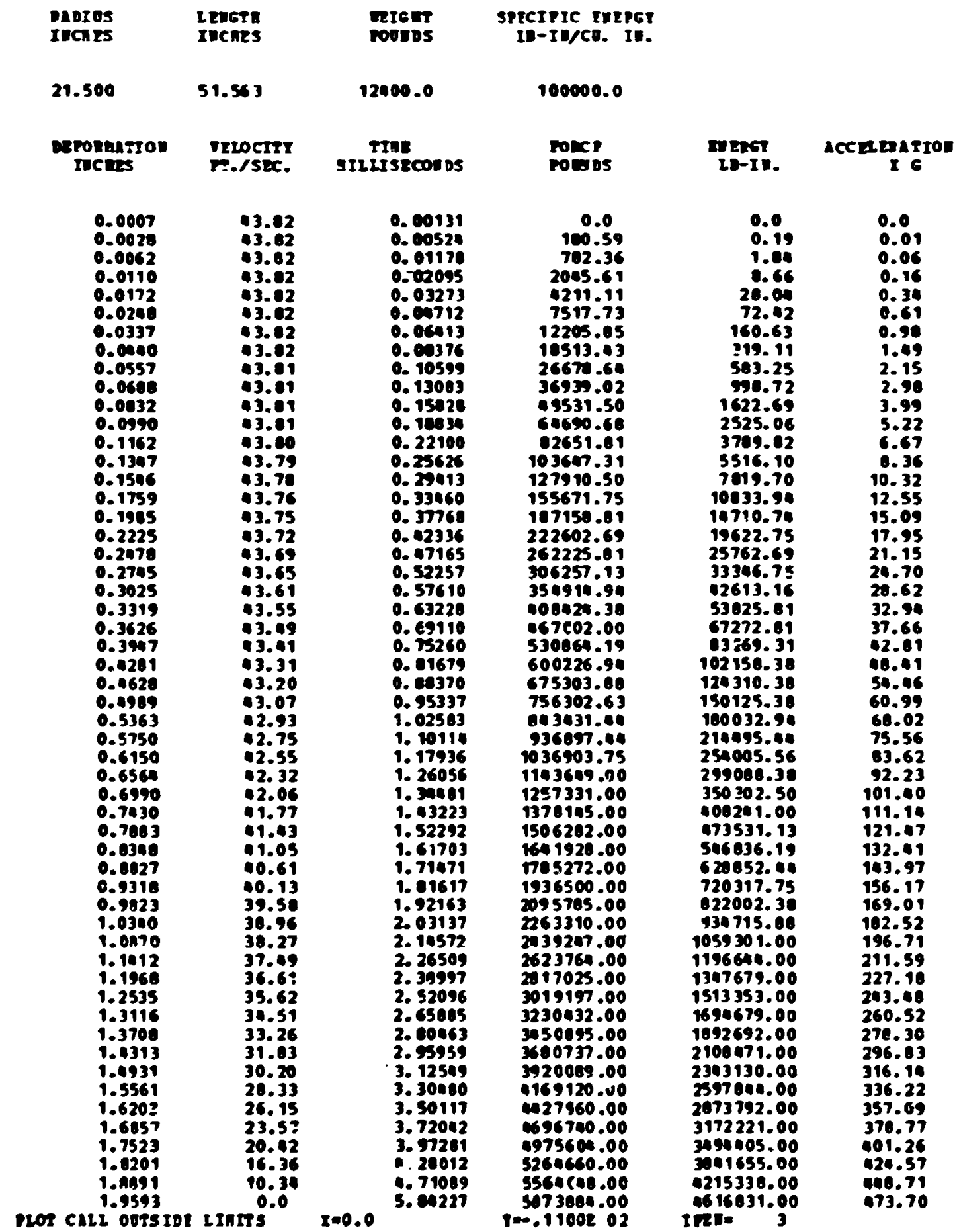




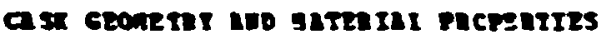

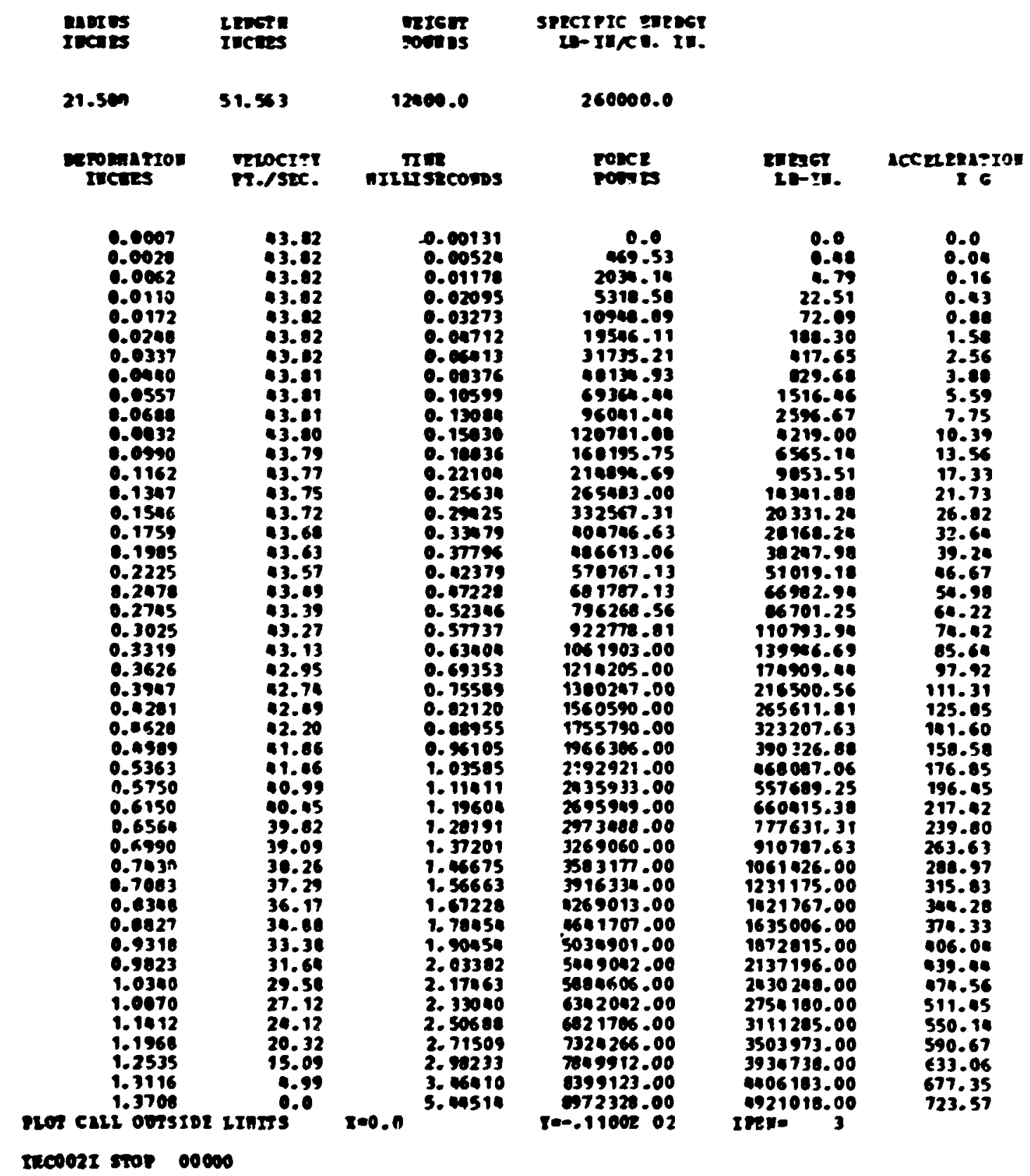




\subsection{Appendix D: Computer Program to Calculate Side Drop Negative Acceleration Forces}

The computer program was the same as derived in Appendix C. howeter. the program was changed to reflect the change in the angle of impact. The angle. a. in Fig. C.1 was $63^{\circ}$ for the side drop.

The results for specific energies for stainies: steel of 100,000 and 260.000 in.-16 in." are given. The plots of the negative accekrations vs deformation are given in Figs. D.I and D.2. 


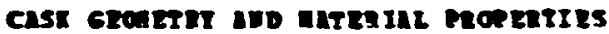

\begin{tabular}{|c|c|c|c|c|c|}
\hline $\begin{array}{l}\text { aneres } \\
\text { incirs }\end{array}$ & $\begin{array}{l}\text { LEwT: } \\
\text { ILCTES }\end{array}$ & $\begin{array}{l}\text { Trter } \\
\text { rovers }\end{array}$ & $\begin{array}{l}\text { SPECIPIC Ewens } \\
\text { ID-y yree. It. }\end{array}$ & & \\
\hline 21.500 & 51.553 & 12400 & 19еме. & & \\
\hline roventor & $\begin{array}{l}\text { pewoctrt } \\
\text { r.psec. }\end{array}$ & $\begin{array}{l}\text { TIn: } \\
\text { aristowes }\end{array}$ & $\begin{array}{l}\text { roucz } \\
\text { potes }\end{array}$ & $\underset{10-10 .}{\operatorname{meg}}$ & $\begin{array}{c}\text { acceserto: } \\
\times 6\end{array}$ \\
\hline 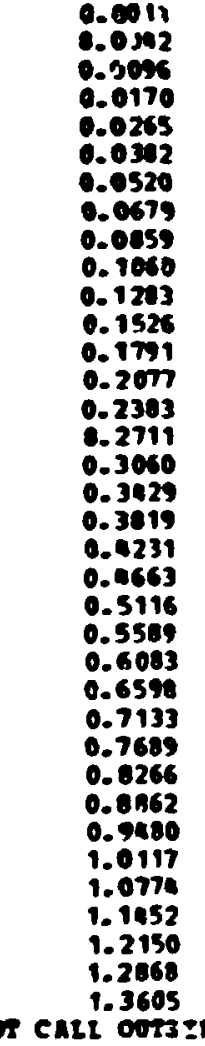 & 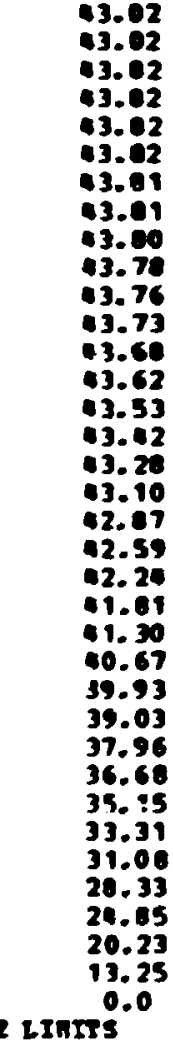 & 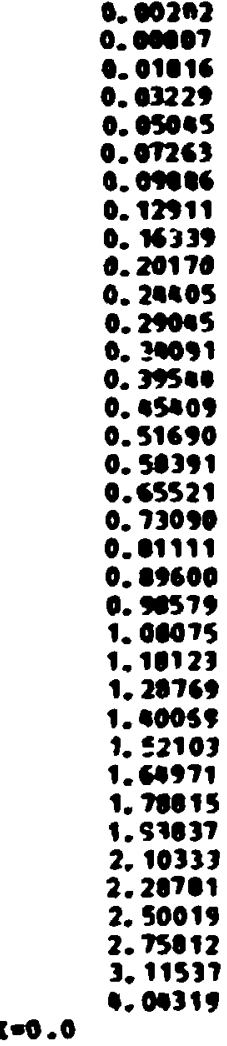 & 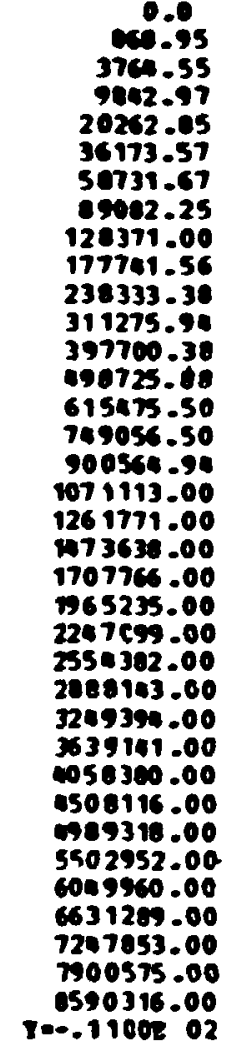 & 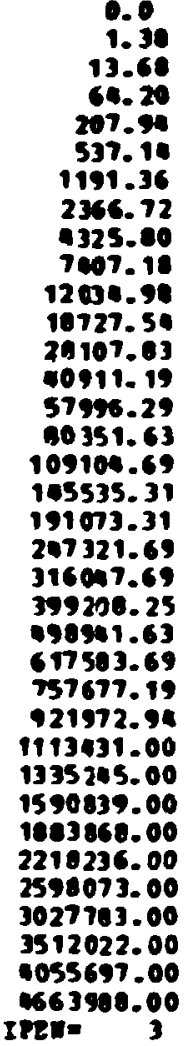 & 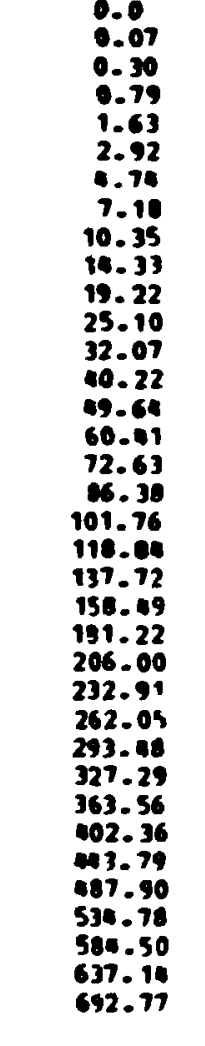 \\
\hline
\end{tabular}




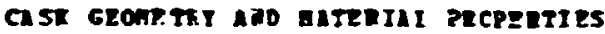

\begin{tabular}{|c|c|}
\hline $\begin{array}{l}\text { Papres } \\
\text { Incues }\end{array}$ & $\begin{array}{l}\text { IEnGT } \\
\text { IDCWES }\end{array}$ \\
\hline 21.500 & 51.563 \\
\hline $\begin{array}{l}\text { Detomatros } \\
\text { Incies }\end{array}$ & $\begin{array}{l}\text { nexocist } \\
\text { nt-/ske. }\end{array}$ \\
\hline $\begin{array}{l}0.0011 \\
0.0007 \\
0.0096 \\
0.0170 \\
0.0265 \\
0.0382 \\
0.0520 \\
0.0679 \\
0.0059 \\
0.1060 \\
0.1203 \\
0.1526 \\
0.1791 \\
0.2077 \\
0.2383 \\
0.2711 \\
0.3060 \\
0.3429 \\
0.3819 \\
0.2231 \\
0.4663 \\
0.5116 \\
0.5589 \\
0.6083 \\
0.6598 \\
0.7133 \\
0.7603 \\
0.8766 \\
0.0662 \\
0.9480 \\
0.07951\end{array}$ & 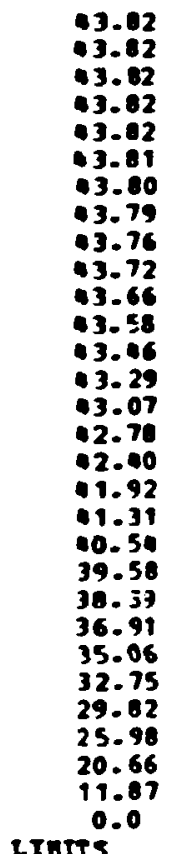 \\
\hline
\end{tabular}

InC002I s?op 00000
Eetcat SPECITIC EnEgT
now es

12000.0

260000.0

TI

nILII stcosos

resel

pose

IDI. I.

accelenation

I 6

0.00202
0.00007
0.01816
0.03229
0.05095
0.07260
0.09696
0.12912
0.16392
0.20176
0.24920
0.29073
0.39190
0.79628
0.45596
0.51901
0.58728
0.66032
0.73050
0.82225
0.91212
1.00092
1.11379
1.22819
1.35971
1.99732
1.66337
1.86933
2.17503
3.04118 $\mathbf{I} \bullet 0.0$

0.0

2259.27

9707.82

25591.73

52683.11

90051.25

152702.31

231613.88

33374.69

462128.19

619666.88

809317.90

1039027.00

$129668 ? .00$

$\mathbf{1 5 0 2 3 6 . 0 0}$

1907586.00

2341460.00

2784es4. .00

3280604.00

3831059.00

440193.00

5109613.00

$\operatorname{sen} 2458.00$

66.1394.00

7509174.00

$24 \times 2420.00$

9961768.00

10551788.00

11721101.00

12972229.00

$1=-.11002$ o2

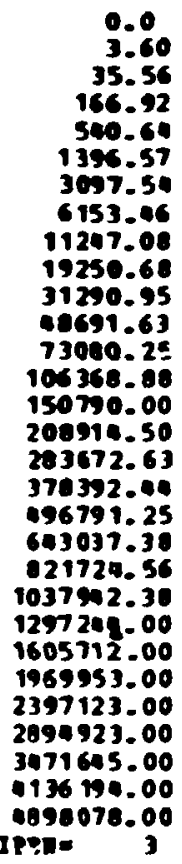

0.0

0. 10

0.79

2.06

. .25

7.50

12.31

10.68

26.92

37.27

49.97

65.27

03.39

104.57

129.05

157.06

108.83

224.59

269.56

308.99

358.08

012.07

671.17

535.60

605.58

61.32

763.05

850.95

945.25

1046. 15 


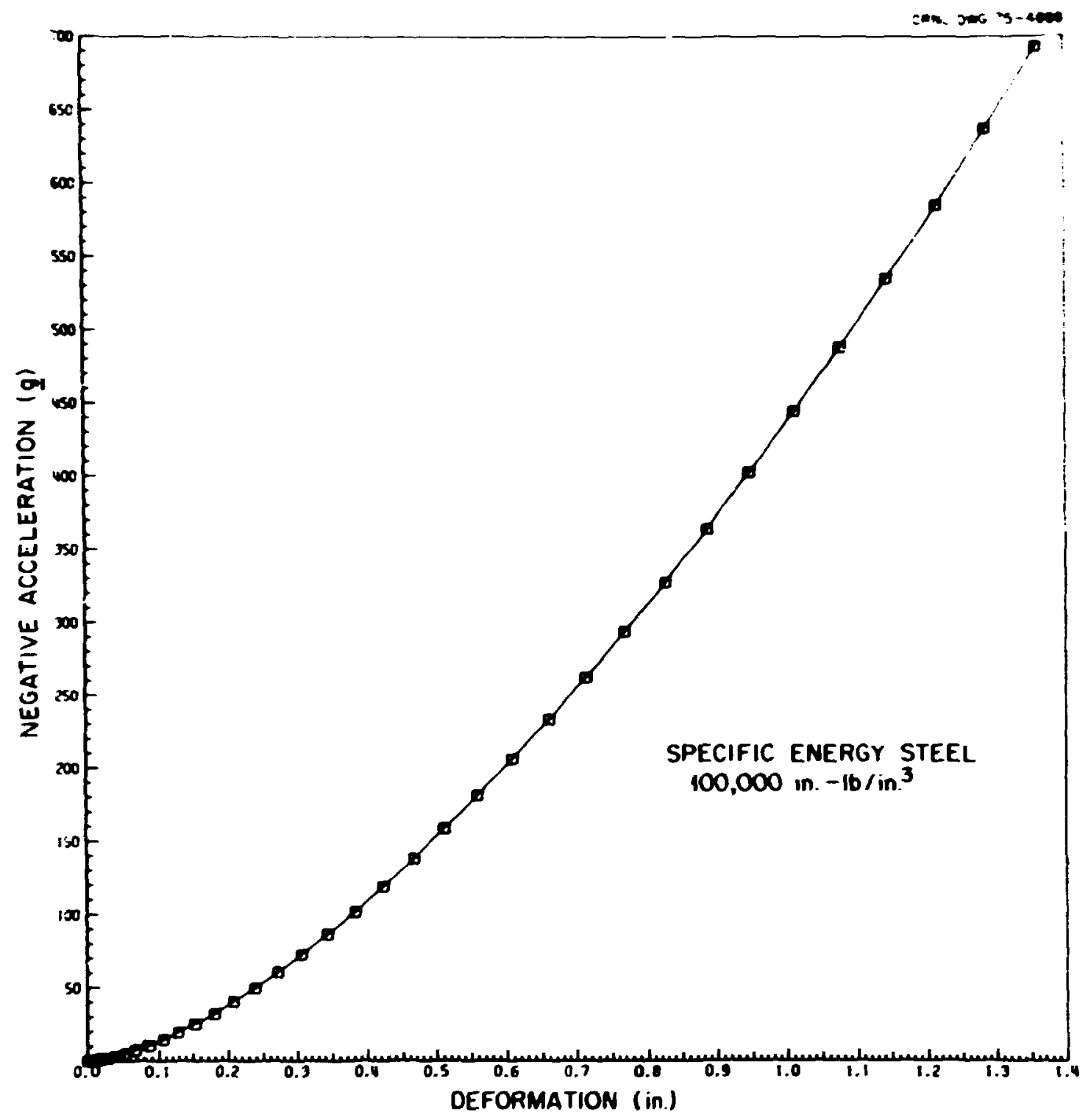

Fig. D.1. Plot of negative acceleration vs deformation at specific energy of $100,000 \mathrm{in} .-1 \mathrm{~b} / \mathrm{in}^{3}$ for steel for the $30-\mathrm{ft}$ side drop. 


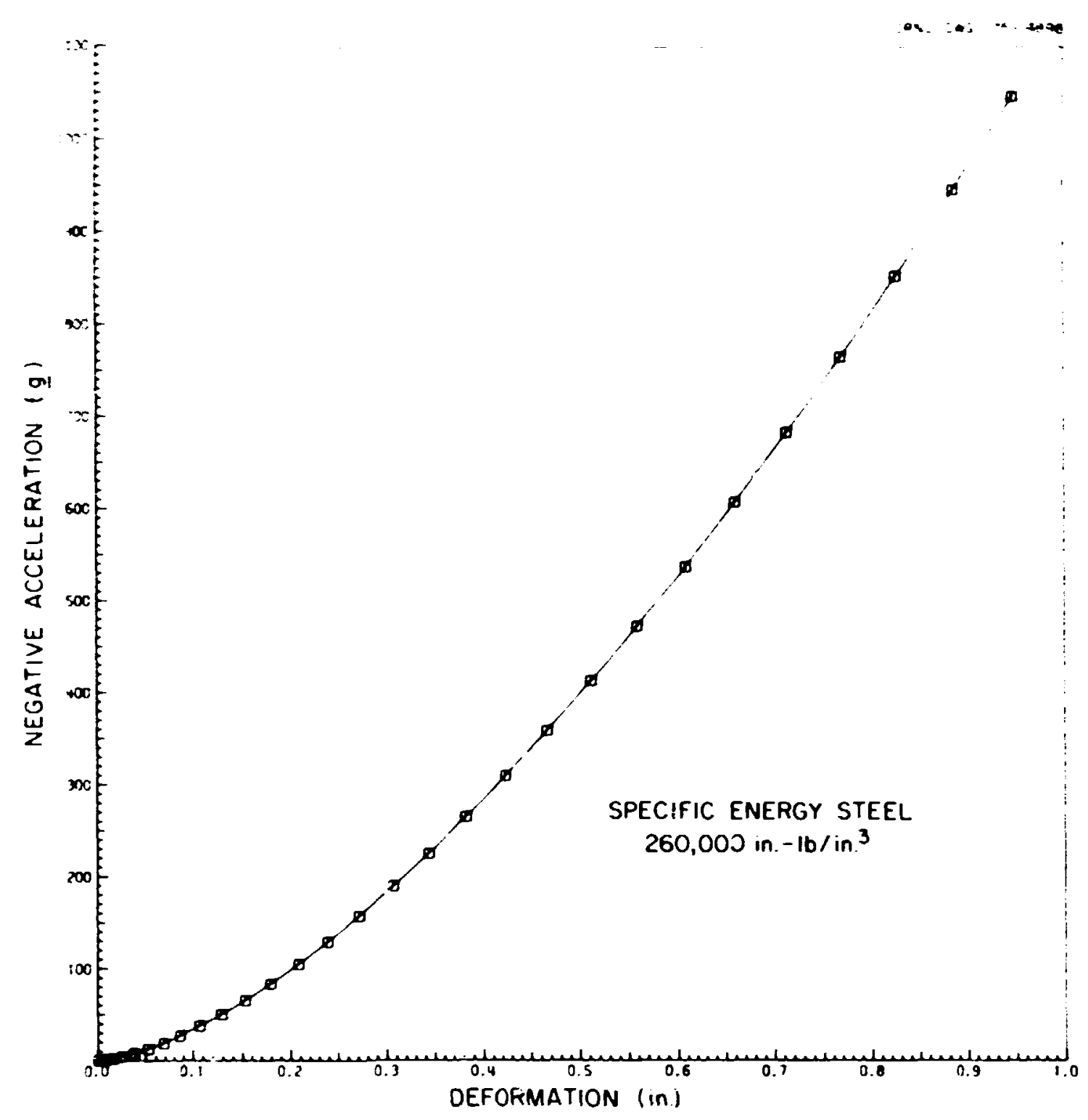

Fig. D.2. Plot of negative acceleration vs deformation at specific energy at 260,000 in. $-1 \mathrm{~b} / \mathrm{in} .{ }^{3}$ for steel for the $30-\mathrm{ft}$ side drop. 


\subsection{Appendix F. Report of Special Inspection of Carden Carrier Vo. 2}

The (iarden (arrier Yis. 2 was constructed before quality assursnce records were maintained at the OR.NI. shops. A thorough inspection was made of the cask and the letter report on that inspection is uncluded in this appendix. 


\title{
INTRÁ.LABORATORY CORRESPONDENCE
}

OAK RIDGE MATIONAL LABORATORY

\author{
December 21,1973
}

TO:

B. B. KIima

SUBJECT :

Injpection of shipping cask - Garden Carrier $\$ 2$

Work Order A-3043C-AA Inspection Request 10927

This inspection was performed to verify the integrity of this shipping cask.

The casi was surveyed by ORNL Health Physics and found to be free of radioactive contamination.

\section{Visual Inspection}

This cask conforms to the characteristics of Drawing M-11332EM-010-E Rev. 2.

The cask is properly identified by stamped lettering.

No structurual defects were observed in the cask or shipping paiset.

Lifting attachments are adequate and of sound construction.

Liguid Penetrant Examination

All accessible welds and lifting attachments were examined with liquid peretrant in accordance with ORNL Standard NDE-30, Technique 1, "Color Contrast solvent-removal"le" and were found to be satisfactory.

Leak Test

A vacuum test was made on the assembled cask. The internal cavity was evacuated to $250 \mathrm{microns}$ pressure. Pressure rise test indicated a return to atmospheric pressure in approximately 15 minutes. 


\section{Material Identification}

Thickness measurements were made of the lead containing assemblies. These thicknesses are in accordance with drawing sepcifications.

All accessible parts were examined with a thermoelectric comparator and determired to have been fabricated from 300 series stainless steel.

These inspections and tests indicate good quality materials and welds.

It is our opinion that the integrity of this cask is of equal quality to comparable shipping casks currently being fabricated.

\section{INSPECTION ENGINEERING DEPARTMENT}

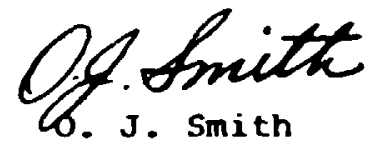

OJS : pg

cc: J. R. McGuffey

J. N. Robinson

C. R. Starlin

IR-10927 
12.6 Appendix F: Operating Precedures Applicable to the Garden Carrier No. :

The operatiag procedures an vary from shipment to shipment depending upon the tollouing: 11 ihe cell or place from which the centents are picked up or discharged into: (2) the type of inner container luhether or not it must be unloaded remotely using manipulators: (3) the desigia of the discharge hole (tworizontal or vertical, and other contingencies. The operating procedures included are typical and more general. More detailed procedures will be deleloped to cover the specific contingencies.

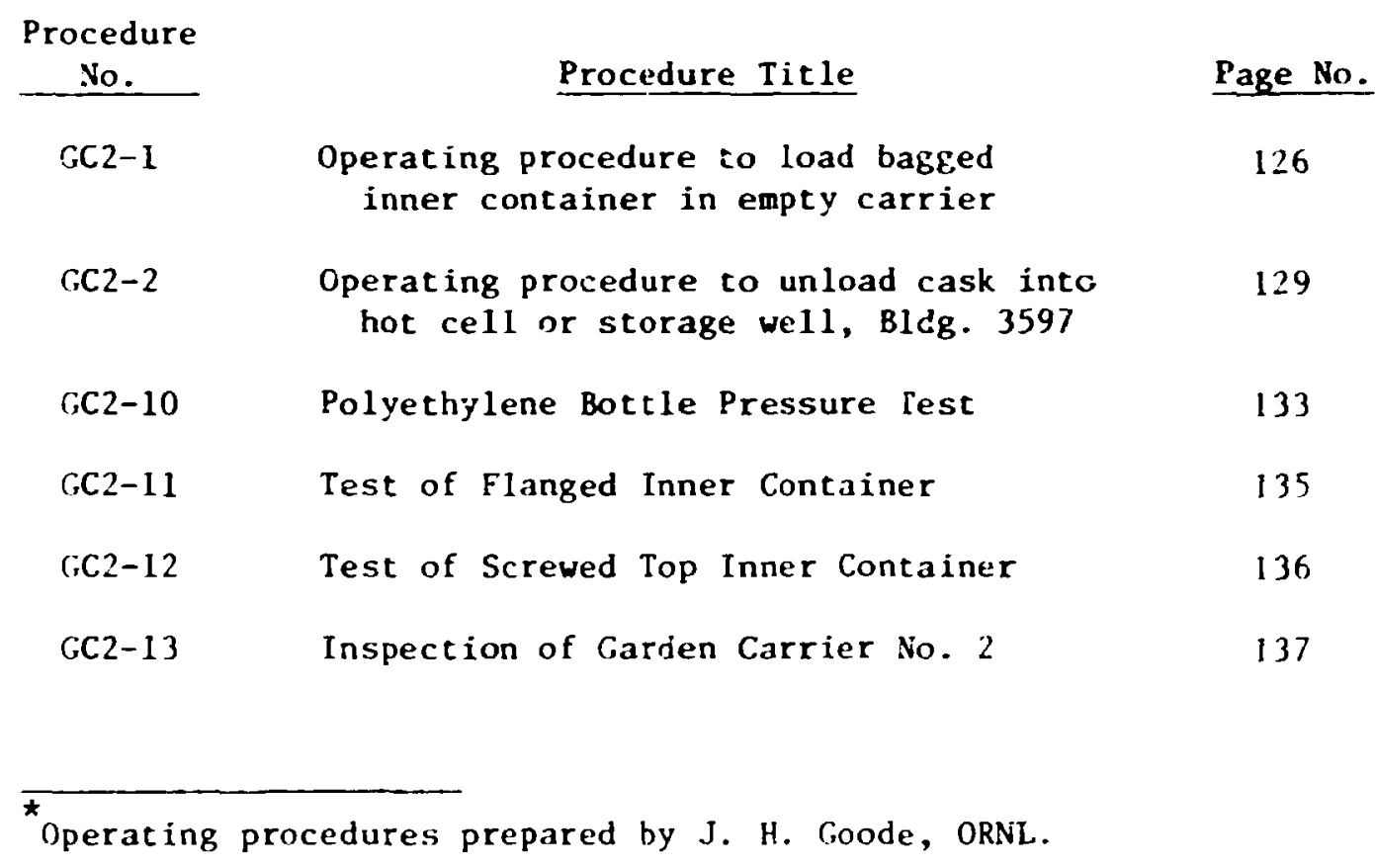


Garden Carrier No. 2

AEC-OR-USA-6088/BLF

\section{OPERATING PROCEDURE TO LOAD BAGGED INNER CONTAINER IN EMPTY CARRIER}

1. Upon arrival (at discharge site) of Garden Carrier No.2, have Health Physics representative survey fire shield, skid, and vehicle for alpha and beta-gama radiation and transferabie contamination.

\begin{tabular}{|c|c|c|c|c|c|c|}
\hline & \multicolumn{2}{|c|}{$a d / \mathrm{m} / 100 \mathrm{~cm}^{2}$} & \multicolumn{2}{|c|}{$3-x$} & \multirow[b]{2}{*}{ Inspector } & \multirow[b]{2}{*}{ Date } \\
\hline & 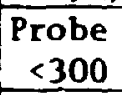 & $\begin{array}{c}\text { Smear } \\
<30 \\
\end{array}$ & Probe & Smear & & \\
\hline \multicolumn{7}{|c|}{ Fire shield } \\
\hline \multicolumn{7}{|l|}{ Skid } \\
\hline Vehicle & & & & & & \\
\hline
\end{tabular}

Is decontamination necessary?

Decontamination completed.

2. Remove fire shield and cask from skid using large hex key wrench located in tool box cn skid to loosen socket-head cap screws. Store bolts for reuse. Inspect bolts for defect. If bolts are reusable, stow in safe place.

If need replacement, record number and type of bolts used.

3. Raise cask and set it on firm supports (wood blocks) to permit access to and removal of the cover from the bottom discharge hole. Inspect bolts. Necessary to replace bolts.

Bolts replased (type number).

Inspect gasket seating surface. Surface ok.

Needs rework. Surface ropaired.

Stow bolts, gasket, and cover for reuse.

4. Remove socket-head cap screws if the top plug is to be lifted to expose the cavity. The top plug may be lifted by eye-bolts inserted 
inte the boit holes for the aluminum cover or jy using a cievis or shackle through the 1 id $l$ ifting lug.

Monitor for radiation contamination as cover is being raised. Decontamination necessary.

Completed.

Inspizct bolts. Vecessary to replace bolts.

Bolt:; replaced (type number).

Store bolts for reuse.

Gieck condition of "o"-ring gasket (neoprene l/4-in.-dian by

18-1!2-in. ID $x$ 19-in. Oi) on body of cask.

"O"--ing gasket needs replacement.

" 0 "-ring gasket replaced.

5. To lnad empty inner container, place containe'r in a remotely removable piast ic bag.

Through the Top

5a. Remove wire rope nolk cover. Insert nylon cord or ioraided stainless steel cable through hole a: bottom of receptacle and attach it to lifting $r$ ing on inner container lid. Place bagged container in cas'z cavity, and carefully replare the top piug of cask to prevent rulting the cord or cable or damaging gasket.

Insert and tigiten 12 socket-head cap screws holding plug in place. Coil excess string inside receptacle. (Be

sure string is tied so it cannot slip down hole. Replace receptacle gasket and cover plate.

Insert and tighten six socket head rap screws.

\section{Through the Bottom}

5b. (Dn not remove the top plug.)

Remove bottom closure (see 4 above).

Remove drawer cover bolts.

Remove drawer covers. 
Procedure GC2-1

Page 3 of 3

Date

Remove drawer bolts.

Store bclts and covers for reuse.

Remove wire rope hole cover bolts.

Remove wire rope hole cover plate.

Open drawers (check for radiation contamination).

Decontaminaion necessary. Completed.

Insert nylon cord or braided stainless wire cable through hole and attach it to lifting ring on inner contaner lid.

Pull bagged inner container into cavity.

Close drawers. Secure drawers with bolts.

Coil excess nylon cord or braided stainless wire cable inside receptacle.

Be sure string is knotted so it cannot slip down hole. Replace receptacle gasket cover.

Replace receptacle cover plate.

Insert and tighten six socket-head cap screws.

Replace drawer cover plates gasket and cover plates.

Inspect gaskets. Need replacement. Replaced.

Insert and tighten drawer cover plate bolts.

Replace bottom cover and gasket.

Insert and tighten bottom cover bolts. 
Procedure (iC:2-2

Page 1 of :-

Date

Garden Carrier lo. 2

AEC-OR-LSA-6088/BLF

OPERATIX: PROCEDLRE TO LNLOAD CASK INTO HOT CELL

OR STORAGE WELL, BLD;, 3597

1. Lpon arrival (at discharge site) of (iarden Carrier No. 2, have Health Physics representative survey fire shield, skid, and vehicle for alpha and beta-gama radiation and transferable contamination.

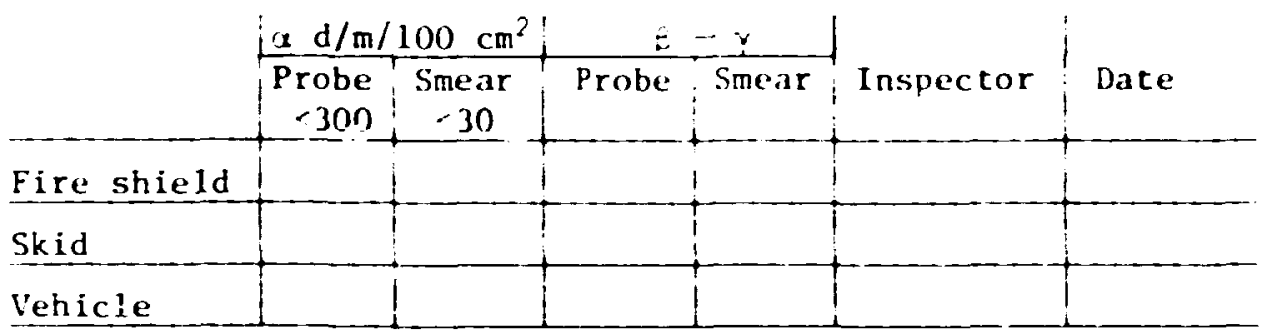

Is decontamination necessary?

Decontamination completed.

2. Remove fire shield and cask from skid using large hex key wrench located in tool box on skid to loosen socket-head cap screws.

Store bolts fur reuse. Inspect bolts for defects. If bolts a e reusable, stow in safe place.

If need replacement, record number and type of bolts used.

3. Raise cask and set it on $\mathrm{f}$ irm supports (wood blocks) to permit access to and removal of the cover from the bottom discharge hole. Inspect bolts. Necessary to replace bolts.

Bolts replaced (type number).

Inspect gasket seating, surface. Surface ok.

Needs rework. Surface repaired.

Stow bolt:, gasket, and cover for reuse.

4. Position cask over hole into hot cell or storage well at Bldg. 3597. 
5. Prepare cask for discharge of contents.

Rewove drawer cover bolts.

Remove drawer covers.

Remove drawer bolts.

Store drawer bolts and covers with bolts and gaskets for reuse.

Rewove string hole cover plate bolts.

$R$ rove string hole cover and gasket.

Store string hole bolts, cover, and gasket for reuse.

Apply tension to string to lift inner container from the drawers.

Open drawers.

Open cell or storage well closure.

Lower inner container into cell or storage well.

Monitor (Health Physics) passage of contents into cell.

If inner containe: is to be retrieved, proceed. However, if inner container is to be left in cell or storage well, the string may be elected to be dropped into the container.

Retrieve the string.

Empty or fill inner container.

Raise inner container into the cask with string.

Monitor passage of inner container into cask.

close drawers.

Lower inner container onto drawers.

Coll excess string in string hole.

String hole:

Inspect gasket seating surface body.

Inspect gasket seating surface flange.

Inspect gasket.

Gasket needs replacement. Replaced

Seating surface needs iefinishing.

Rafinished. 
Procedure GC2-2

Page 3 or 4

Date

Install gasket. Install cover.

Install and tighten bolts. Doors:

Door bolts installed.

Door Covers :

Inspect right gasket seating surface body.

Inspect left gasket seating surface body.

Inspect right gasket seating surface flange.

Inspect left gasket seating surface flange.

rasket needs replacement. Replaced.

Seating surface needs refinishing.

Ref́inished.

Install door cover gasket and door.

Install and tighten door cover bolts.

Inspect botton cover gasket.

Inspect bottom cover gasket seating surface on cask.

Inspect bottom cover gasket seating surface on cover.

Gasket needs rep:acement. Replaced.

Gasket seating surface needs refinishing.

Ref in ished.

Install bottom cover and gasket.

Install and tighten bottom cover bolts.

6. Survey cask for radiation and contamination on all surfaces.

\begin{tabular}{|c|c|c|c|c|c|c|}
\hline & \multicolumn{2}{|c|}{ a d/m/100 $\mathrm{cm}^{2}$} & \multicolumn{2}{|c|}{$\beta-\gamma$} & \multirow[b]{2}{*}{ Inspector } & \multirow[b]{2}{*}{ Date } \\
\hline & $\begin{array}{r}\text { Probe } \\
<300 \\
\end{array}$ & $\begin{array}{c}\text { Smear } \\
<30 \\
\end{array}$ & Probe & Smear & & \\
\hline hipping cask & & & & & & \\
\hline
\end{tabular}

Is dizcontamination necessary?

Decontamination completed.

$\eta$ Lifting cask on shipping skid.

8. Secure cask to shipping skid with bolts; tighten them. 
Procedure GC2-2

Page 4 of 4

Date

9. Place fire shield over cask.

Insert and tighten bolts on fire shield.

10. Replace tools in tool box.

Lock tool box.

11. Survey assembly for radiation and contamination on all surfaces.

\begin{tabular}{|c|c|c|c|c|c|c|}
\hline & \multicolumn{2}{|c|}{$\alpha \mathrm{d} / \mathrm{m} / 100 \mathrm{~cm}^{2}$} & \multicolumn{2}{|c|}{ e $x$} & \multirow[b]{2}{*}{ Insfector } & \multirow[b]{2}{*}{ Date } \\
\hline & 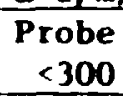 & $\begin{array}{c}\text { Smear } \\
<30\end{array}$ & Probe & Smear & & \\
\hline \multicolumn{7}{|c|}{ Fire shield } \\
\hline Skid & & & & & & \\
\hline
\end{tabular}

Cask is ready for transmittal to shipping. 
Procedure GC2-10

Page 1 of 2

Date

\section{Garden Carrier No. 2}

Test Procedure

GC2-10 Polyethylene Bcttle Fressure Test

1. Inspect bottle for flaws.

2. Check "0"-ring (Viton - Fluorelastomer or approved equivalent).

3. Close with special cap. (180 in.-1bs. torque)

4. Pressurize to 25 psig using air.

5. Shut of air supply.

h. Submerge bottle in water and examine for leaks.

Frequency: Before use. (No container is used more than once.)

Record data on attached Table. 
Procedure $\mathrm{CC} 2-10$

Page 2 of 2

Date

Polyothylene Bottle Pressure Test

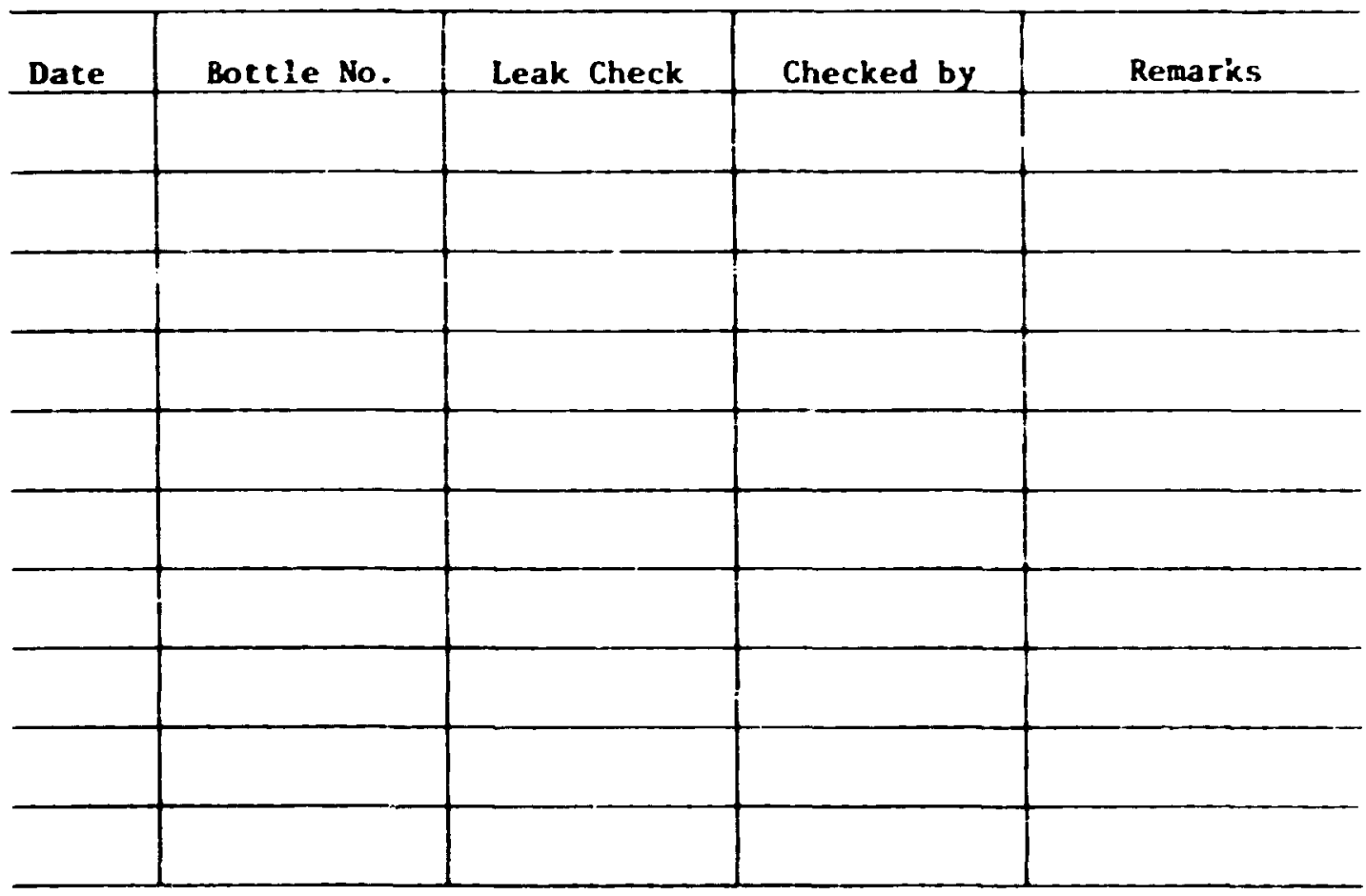


Procedure G,C2-11

Date

\section{Garden Carrier No. 2 \\ Test Procedure*}

GC2-11 Test of flanged inner container for

(drawing M-11332-EM-020-D)

1. Inner container fabricated in accordance with drawing.

2. Inner container assigned a serial numter and so identified.

3. Bubble test 25 psig.

Container approved for use

Date

* Test annually or on putting new container in service. 
Procedure GC2-12

Date

Garden Carrier No. 2

Test Procedure

GC2-12 Test of screwed top inner container

(drawing M-11332-EM-019-0)

1. Inner container fabricated in accordance with drawing.

2. Inner container assigned a serial number and so ident if ied.

3. Bubble test at 25 psig.

* Test before each shipment. 
Procedure: ; $2-13$

Date

Garden Carrier io. 2

Test Procedure*

r, $2-13$ Test of Ciarden Carrier lo. 2

1. Dye penetrant test all accessible welds and lifting attachments in accordance with ORNL-Standard NDE-30.

Technique 1. "Color Contrast Solvent Removable"

2. Apply vacuum test to assembled cask. Evacuate to 250

microns. If pressure $r$ ise to atmospheric is less than 15 minutes, gaskets should be replaced or leakage source invest igated.

initial vacuum

microns

final vacuum

elapsed time

Cask is acceptable to use

* Test biennially. 


\section{RF.FT.RE.:ICES}

2. B. B. Klima, Analysis of the Oak Ridge National Laboratory Garden Carrier No. 2, ORNL/TM-2531 (September 19599).

2. Code of Federal Regulations, Title 10, Chapter 1 (May 1975).

3. ERDA Manual, Chapter 0529 (June 14, 1973).

4. Code of Federal Regulations, Title 49, Part 173.

5. Code of Federal Regulations, Title 49, Part 173, Paragraph 173.393(j).

6. J. H. Evans, Analysis of the Oak Ridge National laboratory Dry Hole Charger Shipping Cask, ORNL/TM-2302 (December 1965).

7. R. J. Roark, Formulas for Stress and Strain, 4th ed., Mcíraw-Hill, New York, 1965.

8. J. H. Evans, Structural Analysis cf Shipping Casks, Vol. 7, Cask Tie-Down Design Manual, ORNL/TM-1312, Vol. 7 (May 1969).

9. E. Oberg and F. D. Jones, P. 1110 in Machinery's Handbook, l6th ed., The Industrial Press, New York, 1959.

10. F. L. Singer, pp. 329-46 in Strength of Materials, Harper, New York, 1951 .

11. ASmE Boiler and Pressure Vessel Code, Sect. VIII, "Rules for Construction of Vessels," Jivision 1, American Society of Mechanical Engineers, New York, 1974.

12. Code of Federal Regulations, Title 49, Part 173, Paragraph $173.393(e)(2)$.

13. W. D. Turner and M. Siman-Tov, HEATING-3, An IBM 360 Heat Conductío: Program, ORNL/TM-3208 (Fe!)ruary 1971).

14. D. D. Cannon, Structural Analysis of Shipping Casks, Vo1. 12, Energy Absorption Characteristics of Stainless Steel Bolts Under Impact Loajings, ORNL/TM-1312, Vo1. 12, p. 55 (1972).

15. J. H. Evans, Safety Analysis Report for Packaging Lawrence Livermore Laboratory Shipping Container, ORNL/TM-4905 (December 1975).

16. B. B. Klima and L. B. Shappert, Safety Analysis Report Packaging ORNL Shipping Cask D-38, ORNL/TM-4485 (in preparation). 